\title{
Cascade radical cyclizations of benzannulated enyne-allenes and development of new synthetic strategies for novel polycyclic aromatic compounds
}

\author{
Yonghong Yang \\ West Virginia University
}

Follow this and additional works at: https://researchrepository.wvu.edu/etd

\author{
Recommended Citation \\ Yang, Yonghong, "Cascade radical cyclizations of benzannulated enyne-allenes and development of new \\ synthetic strategies for novel polycyclic aromatic compounds" (2004). Graduate Theses, Dissertations, \\ and Problem Reports. 2097. \\ https://researchrepository.wvu.edu/etd/2097
}

This Dissertation is protected by copyright and/or related rights. It has been brought to you by the The Research Repository @ WVU with permission from the rights-holder(s). You are free to use this Dissertation in any way that is permitted by the copyright and related rights legislation that applies to your use. For other uses you must obtain permission from the rights-holder(s) directly, unless additional rights are indicated by a Creative Commons license in the record and/ or on the work itself. This Dissertation has been accepted for inclusion in WVU Graduate Theses, Dissertations, and Problem Reports collection by an authorized administrator of The Research Repository @ WVU. For more information, please contact researchrepository@mail.wvu.edu. 
Cascade Radical Cyclizations of Benzannulated Enyne-Allenes and Development of New Synthetic Strategies for Novel Polycyclic Aromatic Compounds

\author{
Yonghong Yang \\ Dissertation submitted to the \\ Eberly College of Arts and Sciences \\ at West Virginia University \\ in partial fulfillment of the requirements \\ for the degree of
}
Doctor of Philosophy
in
Organic Chemistry

\author{
Kung K. Wang, Ph.D., Chair \\ Harry O. Finklea, Ph.D. \\ Peter M. Gannett, Ph.D. \\ Jeffrey L. Petersen, Ph.D. \\ Björn C. G. Söderberg, Ph.D. \\ C. Eugene Bennett Department of Chemistry
}

Morgantown, West Virginia

2004

Keywords: Cycloaromatization, Biradical, Enyne-Allene, Polycyclic Aromatic Compound Copyright 2004 Yonghong Yang 


\title{
ABSTRACT \\ Cascade Radical Cyclizations of Benzannulated Enyne-Allenes and Development of New Synthetic Strategies for Novel Polycyclic Aromatic Compounds
}

\author{
Yonghong Yang
}

The cascade radical cyclization of benzannulated enyne-allene generated in situ from enediynyl propargylic alcohols promoted by thionyl chloride via an $\mathrm{S}_{\mathrm{N}} \mathrm{i}^{1}$ reaction provides an efficient synthetic pathway to $11 H$-benzo[b]fluoren-11-ols and related compounds. The simplicity of the synthetic sequence and the mildness of the reaction condition make this cascade reaction sequence useful for the construction of polycyclic aromatic compounds. Interestingly, when this strategy was employed for the systems having two benzannulated enyne-allene units, it was quite unexpected that the reaction sequence led to the formation of highly twisted 1,1'dialkyl-9,9'-bifluorenylidenes involving an unusual cleavage of a benzene ring, and spiro[1 $1 \mathrm{H}$ cyclobut $[a]$ indene-1,9'-[9H]fluorenes] along with other polycyclic aromatic compounds. Conceivably, the transformation from the precursors having two benzannulated enyne-allene units to the novel polycyclic compounds involves a $\mathrm{C}^{2}-\mathrm{C}^{6}$ cyclization reaction followed by a radical-radical coupling reaction and a tautomerization to give the formal Diels-Alder adducts or the $[2+2]$ cycloaddition adducts.

The Ireland-Claisen rearrangement of the benzannulated enediynyl propargylic acetates was successfully adopted for the synthesis of the corresponding benzannulated enyne-allenes in situ for the subsequent Schmittel cyclization to generate benzofulvene biradicals for cascade radical cyclizations. The mildness of the reaction conditions and the ready availability of a variety of silyl ketene acetal make this synthetic pathway quite attractive. Several polycyclic aromatic derivatives of benzo[ghi]fluoranthene and $11 H$-benzo[b]fluorene were thus produced from the corresponding enediynyl propargylic acetates in a single operation.

The Wagner-Meerwein rearrangement of fluorenylmethanols derived from 15,16-diaryldiindeno[2,1-b:1',2'-h]phenanthrenes was successfully adopted for the synthesis of helical 17,18diaryl-dibenzo[ $[a, o]$ pentaphenes involving the carbocation-promoted ring expansion and aromatization. Two of the 17,18-diaryl-dibenzo[a,o]pentaphenes were employed for the subsequent intramolecular Friedel-Crafts arylation reactions involving phenyl or 4-biphenylyl substiuents at the $17 \& 18$ positions, producing several butterfly-shaped compounds having two planes of symmetry and a $C_{2}$ symmetry in the case of the phenyl substituent and having only a $C_{2}$ symmetry in the case of the 4-biphenylyl substituent. They possess very interesting structural features. 


\section{DEDICATED TO}

my husband, Shengqiao Li, and my parents 


\section{ACKNOWLEDGEMENT}

I would like to express my sincere appreciation to my research advisor, Dr. Kung K. Wang, for his valuable guidance, constant encouragement, and constructive comments throughout the course of this research. I have greatly benefited from his extensive knowledge of chemistry, inspirational personality, and great enthusiasm in discussing chemistry with students.

I also want to express my gratitude to my research committee members, Dr. Harry O. Finklea, Dr. Peter M. Gannett, Dr. Jeffrey L. Petersen, and Dr. Björn C. G. Söderberg for their helpful suggestions and valuable discussions. My special thanks go to Dr. Jeffrey L. Petersen for his significant work in X-ray crystal structure analysis of the unusual compounds.

My appreciation is also extended to the former and present group members in Dr. Wang's research laboratory, Dr. Hai-Ren Zhang, Dr. Hongbin Li, Xiaoqing Han, Dr. Xiaoling Lu, Yanzhong Zhang, Hua Yang, Weixiang Dai, Josh Bailey, and Yu-Hsuan Wang for their help and discussions. I enjoyed the research work very much with their company.

I want to express my special thanks to my husband and my parents for their permanent love, understanding, and constant encouragement. I cannot imagine how can I reach this point without their support.

Financial support from the C. Eugene Bennett Department of Chemistry of West Virginia University, the National Science Foundation, and the Petroleum Research Fund, administered by the American Chemical Society, to Dr. Wang is gratefully acknowledged. 


\section{TABLE OF CONTENTS}

Title Page

$\begin{array}{ll}\text { Abstract } & \text { ii }\end{array}$

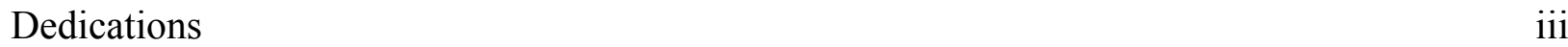

Acknowledgement iv

Table of Contents $\quad v$

List of Tables

List of Figures $\quad$ ix

List of ${ }^{1} \mathrm{H}$ NMR and ${ }^{13} \mathrm{C}$ NMR Spectra $\quad$ x

\section{CHAPTER I}

\section{Prelude}

1. Introduction 1

2. Biological Activities and DNA-Cleavage Mechanism of Enediyne Antitumor Antibiotics 3

3. Cyclization Reaction of Enediynes via Bergman Cyclization 5

4. Cyclization Reaction of Enyne-Allenes 10

4.1. Myers-Satio $\left(C^{2}-C^{7}\right)$ Cyclization $\quad 10$

4.2. Schmittel $\left(C^{2}-C^{6}\right)$ Cyclization 12

4.3. Construction of Polycyclic Ring Systems via Cycloaromatization of Enyne-Allenes 13

4.4. Cyclization Reaction of Hetero Eenyne-Allenes and Their Applications to the Synthesis of Novel Heterocyclic Ring Systems 16

5. Literature Survey on the Synthetic Methodologies for the Preparation of Benzannulated Enyne-Allenes and Acyclic Enyne-Allenes 


\section{CHAPTER II}

Cascade Radical Cyclizations of Benzannulated Enyne-Allenes. Unusual Cleavage of a Benzene Ring Leading to Twisted 1,1'-Dialkyl-9,9'-bifluorenylidenes and Spiro[1H-cyclobut[a]indene-1,9'-[9H]fluorenes].

1. Introduction 23

2. Research Objective $\quad 24$

3. Literature Survey for the 9,9'-Bifluorenylidenes 25

4. Results and Discussion $\quad 25$

4.1. Unusual Cascade Cyclizations of Dipropyl Substituted Propargylic Diol 25

4.2. Unusual Cascade Cyclizations of Dimethyl Substituted Propargylic Diol 29

4.3. Cascade Cyclizations of Benzannulated Propargylic Diol 30

4.4. Other Attempts to Synthesize Polycyclic Aromatic Compounds 31

5. Conclusions

\section{CHAPTER III}

Polycyclic Aromatic Compounds via Radical Cyclizations of Benzannulated Enyne-Allenes Derived from Ireland-Claisen Rearrangement

1. Introduction

2. Research Objective

3. Literature Survey for the Synthesis of Benzo[ghi]fluoranthene, Corannulene and Related Compounds, and Synthetic Pathway for Ring Contraction

3.1. Synthesis of Benzo[ghi]fluoranthene and Related Compounds 36

3.2. Synthesis of Corannulene and Related Compounds 37 
3.2.1. Synthesis of Corannulene via Flash Vacuum Pyrolysis

3.2.2. Synthesis of Corannulene and Related Compounds via Non-pyrolytic Pathway

3.3. Synthetic Pathway for Ring Contraction

3.3.1. Ring Contraction via Lead(IV) Acetate

3.3.2. Ring Contraction via Wolff Rearrangement

4. Results and Discussion

4.1. Polycyclic Aromatic Carboxylic Acids via Ireland-Claisen Rearrangement

4.2. Synthesis of Polycyclic Ketone via Friedel-Crafts Reaction and Attempts to Synthesize Corannulene Derivatives

4.3. $[4+2]$ versus $[2+2]$ Cyclization

4.4. Attempts for Ring Contraction

4.4.1. Attempts for Ring Contraction Catalyzed by $\mathrm{Pb}(\mathrm{OAc})_{4}$

5. Conclusions

\section{CHAPTER IV}

Polycyclic Aromatic Compounds via Wagner-Meerwein Rearrangement of Fluorenylmethanols and Intramolecular Friedel-Crafts Arylation Reactions

1. Introduction

2. Research Objective

3. Literature Survey for the Synthesis of Helical Compounds, Such as Phenanthrenes and Helicenes etc. 
3.1. Synthesis of Phenanthrenes and Related Compounds

3.2. Synthesis of Helicenes and Related Compounds

4. Results and Discussion $\quad 58$

4.1. Synthesis of Dibenz $[a, j]$ anthracene 371

4.2. Synthesis of Helical Compound $\mathbf{3 7 7}$ and Polycyclic Compounds $\mathbf{3 7 8}$ and $\mathbf{3 7 9} \quad 60$

4.3. Synthesis of 4,5-Di(1-naphthyl)phenanthrene 384 and Linear Hydrocarbon $392 \quad 64$

4.4. Synthsis of Diacetylene $\mathbf{3 8 8}$

$\begin{array}{ll}\text { 4.5. Cyclization versus Ring Expansion } & 68\end{array}$

5. Conclusions $\quad 68$

\section{PART V}

\section{Experimental Section}

Instrumentation, Materials and Manipulation

References

Appendix

124

Publications

201 


\section{LIST OF TABLES}

Table 1. Calculated $c d$ Distances and Stabilities of Conjugated Enediynes 7

Table 2. Effects of Substituents on the Reactivity of Enediynes 8

Table 3. Synthesis of Polycyclic Aromatic Carboxylic acids from Diaryl Ketones 44

\section{LIST OF FIGURES}

Figure 1. Structures of naturally occurring antitumor antibiotics from bacterial sources. 2

Figure 2. Structures of naturally occurring antitumor antibiotics from marine sources. 2

Figure 3. Products of thermolysis of (Z)-1,2,4-heptatrien-6-yne (35) in various solvents. 11

Figure 4. Some examples of twisted 9,9'-bifluorenylidenes. 25

Figure 5a. ORTEP drawing of the crystal structure of 1,1'-dipropyl-9,9'-bifluorenylidene 165 with hydrogen atoms omitted for clarity. 28

Figure 6. Examples of phenanthrenes and helicenes. 52

Figure 7. ORTEP drawing of the crystal structure of the syn isomer of $\mathbf{3 8 4 .} 67$

Figure 5b. ORTEP drawing of the crystal structure of 1,1'-dipropyl-9,9'-bifluorenylidene 165.

Figure 8. ORTEP drawing of the crystal structure of polycyclic compound $\mathbf{1 6 7 .} 125$

Figure 9. ORTEP drawing of the crystal structure of polycyclic compound $\mathbf{1 6 8 .} 126$

Figure 10. ORTEP drawing of the crystal structure of polycyclic compound $\mathbf{1 8 2} .126$

Figure 11. ORTEP drawing of the crystal structure of polycyclic compound $\mathbf{1 8 5}$.

Figure 12. ORTEP drawing of the crystal structure of polycyclic carboxylic acid 283. $\quad 128$

Figure 13. ORTEP drawing of the crystal structure of polycyclic ketone 287 . 129

Figure 14. ORTEP drawing of the crystal structure of polycyclic ketone 291 . 129

Figure 15. ORTEP drawing of the crystal structure of polycyclic compound $\mathbf{3 0 6 .} 130$ 
Figure 16. ORTEP drawing of the crystal structure of polycyclic compound $\mathbf{3 1 0}$.

Figure 17. ORTEP drawing of the crystal structure of polycyclic diketone $\mathbf{3 8 0}$.

\section{LIST OF ${ }^{1}$ H NMR AND ${ }^{13}$ C NMR SPECTRA}

${ }^{1} \mathrm{H}$ and ${ }^{13} \mathrm{C}$ NMR Spectra of Propargylic Diol 157a

${ }^{1} \mathrm{H}$ and ${ }^{13} \mathrm{C}$ NMR Spectra of Propargylic Diol 157b

${ }^{1} \mathrm{H}$ and ${ }^{13} \mathrm{C}$ NMR Spectra of Propargylic Diol 157c

${ }^{1} \mathrm{H}$ and ${ }^{13} \mathrm{C}$ NMR Spectra of Diester 163

${ }^{1} \mathrm{H}$ and ${ }^{13} \mathrm{C}$ NMR Spectra of Diketone 164

${ }^{1} \mathrm{H}$ and ${ }^{13} \mathrm{C}$ NMR Spectra of 1,1'-Dipropyl-9,9'-bifluorenylidene 165

${ }^{1} \mathrm{H}$ NMR Spectrum of Polycyclic Compound $\mathbf{1 6 6}$

${ }^{1} \mathrm{H}$ and ${ }^{13} \mathrm{C}$ NMR Spectra of Polycyclic Compound 167

${ }^{1} \mathrm{H}$ and ${ }^{13} \mathrm{C}$ NMR Spectra of Polycyclic Compound 168

${ }^{1} \mathrm{H}$ and ${ }^{13} \mathrm{C}$ NMR Spectra of Diester 177

${ }^{1} \mathrm{H}$ and ${ }^{13} \mathrm{C}$ NMR Spectra of Diester 178

${ }^{1} \mathrm{H}$ and ${ }^{13} \mathrm{C}$ NMR Spectra of Diketone 179

${ }^{1} \mathrm{H}$ and ${ }^{13} \mathrm{C}$ NMR Spectra of 1,1'-Dimethyl-9,9'-bifluorenylidene $\mathbf{1 8 0}$ 146

${ }^{1} \mathrm{H}$ NMR Spectrum of Polycyclic Compound $\mathbf{1 8 1}$

${ }^{1} \mathrm{H}$ and ${ }^{13} \mathrm{C}$ NMR Spectra of Polycyclic Compound 182

${ }^{1} \mathrm{H}$ and ${ }^{13} \mathrm{C}$ NMR Spectra of Diketone $\mathbf{1 8 4}$

${ }^{1} \mathrm{H}$ and ${ }^{13} \mathrm{C}$ NMR Spectra of Polycyclic Compound $\mathbf{1 8 5}$

${ }^{1} \mathrm{H}$ and ${ }^{13} \mathrm{C}$ NMR Spectra of Polycyclic Compound $\mathbf{1 8 6}$ $151-152$

${ }^{1} \mathrm{H}$ and ${ }^{13} \mathrm{C}$ NMR Spectra of Polycyclic Compound $\mathbf{1 8 7}$

${ }^{1} \mathrm{H}$ NMR Spectrum of Tetraacetylenic Hydrocarbon $\mathbf{1 8 8 b}$ 
${ }^{1} \mathrm{H}$ and ${ }^{13} \mathrm{C}$ NMR Spectra of Propargylic Acetate 190

${ }^{1} \mathrm{H}$ and ${ }^{13} \mathrm{C}$ NMR Spectra of Polycyclic Compound $\mathbf{1 9 1} 156$

${ }^{1} \mathrm{H}$ and ${ }^{13} \mathrm{C}$ NMR Spectra of Polycyclic Aromatic Carboxylic Acid 274

${ }^{1} \mathrm{H}$ and ${ }^{13} \mathrm{C}$ NMR Spectra of Propargylic Acetate 279 158

${ }^{1} \mathrm{H}$ and ${ }^{13} \mathrm{C}$ NMR Spectra of Propargylic Acetate 280 159

${ }^{1} \mathrm{H}$ and ${ }^{13} \mathrm{C}$ NMR Spectra of Polycyclic Aromatic Carboxylic Acid $\mathbf{2 8 3}$

${ }^{1} \mathrm{H}$ and ${ }^{13} \mathrm{C}$ NMR Spectra of Polycyclic Aromatic Carboxylic Acid 284

${ }^{1} \mathrm{H}$ and ${ }^{13} \mathrm{C}$ NMR Spectra of Polycyclic Aromatic Carboxylic Acid 285

${ }^{1} \mathrm{H}$ and ${ }^{13} \mathrm{C}$ NMR Spectra of Polycyclic Aromatic Carboxylic Acid 286

${ }^{1} \mathrm{H}$ and ${ }^{13} \mathrm{C}$ NMR Spectra of Polycyclic Ketone 287

${ }^{1} \mathrm{H}$ and ${ }^{13} \mathrm{C}$ NMR Spectra of Polycyclic Ketone 291

${ }^{1} \mathrm{H}$ and ${ }^{13} \mathrm{C}$ NMR Spectra of Polycyclic Aromatic Carboxylic Acid 296

${ }^{1} \mathrm{H}$ and ${ }^{13} \mathrm{C}$ NMR Spectra of Polycyclic Aromatic Carboxylic Acid 302

${ }^{1} \mathrm{H}$ and ${ }^{13} \mathrm{C}$ NMR Spectra of Polycyclic Aromatic Carboxylic Acid $\mathbf{3 0 3} \quad 168$

${ }^{1} \mathrm{H}$ and ${ }^{13} \mathrm{C}$ NMR Spectra of Polycyclic Aromatic Carboxylic Acid 304

${ }^{1} \mathrm{H}$ and ${ }^{13} \mathrm{C}$ NMR Spectra of Polycyclic Aromatic Carboxylic Acid 305

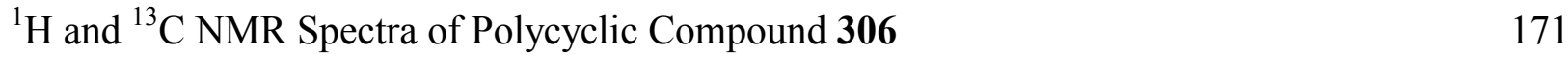

${ }^{1}$ H NMR Spectrum of Polycyclic Ketone 310

${ }^{1} \mathrm{H}$ and ${ }^{13} \mathrm{C}$ NMR Spectra of Polycyclic Hydrocarbon 369

${ }^{1} \mathrm{H}$ and ${ }^{13} \mathrm{C}$ NMR Spectra of Fluorenylmethanol $370 \quad 174$

${ }^{1} \mathrm{H}$ and ${ }^{13} \mathrm{C}$ NMR Spectra of Dibenz $[a, j]$ anthracene 371

${ }^{1} \mathrm{H}$ and ${ }^{13} \mathrm{C}$ NMR Spectra of Fluorenylmethanol $376 \quad 176$

${ }^{1} \mathrm{H}$ and ${ }^{13} \mathrm{C}$ NMR Spectra of 17,18-diphenyl-dibenzo[a,o]pentaphene 377 
$\begin{array}{ll}{ }^{1} \mathrm{H} \text { and }{ }^{13} \mathrm{C} \text { NMR Spectra of Polycyclic Compound } 378 & 178\end{array}$

${ }^{1} \mathrm{H}$ and ${ }^{13} \mathrm{C}$ NMR Spectra of Polycyclic Compound 379 179

${ }^{1} \mathrm{H}$ and ${ }^{13} \mathrm{C}$ NMR Spectra of Polycyclic Diketone 380 180

${ }^{1} \mathrm{H}$ and ${ }^{13} \mathrm{C}$ NMR Spectra of 4,5-Di(1-naphthyl)phenanthrene 384

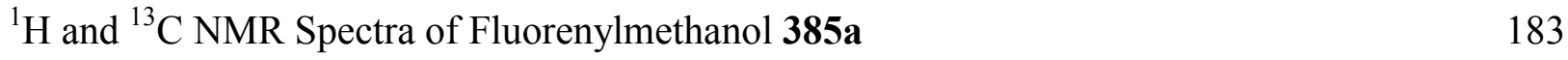

${ }^{1} \mathrm{H}$ and ${ }^{13} \mathrm{C}$ NMR Spectra of Fluorenylmethanol 385b 184

${ }^{1} \mathrm{H}$ and ${ }^{13} \mathrm{C}$ NMR Spectra of 17,18-di(4-biphenylyl)-dibenzo[a,o]pentaphene 386a 185

${ }^{1} \mathrm{H}$ and ${ }^{13} \mathrm{C}$ NMR Spectra of 17,18-di(1-naphthyl)-dibenzo[a,o]pentaphene 386b $\quad 186$

$\begin{array}{ll}{ }^{1} \mathrm{H} \text { and }{ }^{13} \mathrm{C} \text { NMR Spectra of Polycyclic Compound } \mathbf{3 8 7} & 187\end{array}$

${ }^{1} \mathrm{H}$ and ${ }^{13} \mathrm{C}$ NMR Spectra of 1-(2-Ethynylphenyl)-2-(1-naphthyl)ethyne $\mathbf{3 8 8}$

${ }^{1} \mathrm{H}$ and ${ }^{13} \mathrm{C}$ NMR Spectra of Propargylic Diol 390 189-190

${ }^{1} \mathrm{H}$ and ${ }^{13} \mathrm{C}$ NMR Spectra of Tetraacetylenic Hydrocarbon 391

${ }^{1} \mathrm{H}$ and ${ }^{13} \mathrm{C}$ NMR Spectra of Linear Isomer 392

${ }^{1} \mathrm{H}$ and ${ }^{13} \mathrm{C}$ NMR Spectra of 1-(2-Bromophenyl)-2-(1-naphthyl)ethyne $\mathbf{4 0 2} 193$

${ }^{1} \mathrm{H}$ and ${ }^{13} \mathrm{C}$ NMR Spectra of 1-(1-Naphthyl)-2-[2-(trimethylsilylethynyl)phenyl]ethyne 404194

${ }^{1} \mathrm{H}$ and ${ }^{13} \mathrm{C}$ NMR Spectra of Polycyclic Hydrocarbon 405

${ }^{1} \mathrm{H}$ and ${ }^{13} \mathrm{C}$ NMR Spectra of Fluorenylmethanol $406 \quad 196$

${ }^{1} \mathrm{H}$ and ${ }^{13} \mathrm{C}$ NMR Spectra of Polycyclic Hydrocarbon $407 \quad 197$

${ }^{1}$ H NMR Spectrum of Polycyclic Hydrocarbon $408 \quad 198$

${ }^{1} \mathrm{H}$ and ${ }^{13} \mathrm{C}$ NMR Spectra of Propargylic Alcohol $\quad 199$

${ }^{1} \mathrm{H}$ and ${ }^{13} \mathrm{C}$ NMR Spectra of Diacetylenic Hydrocarbon 200 


\section{CHAPTER I}

\section{Prelude}

\section{Introduction}

A novel class of antitumor antibiotic natural products, including calicheamicins (1), ${ }^{1}$ dynemicin (2), ${ }^{2}$ esperamicins (3), ${ }^{3}$ kedarcidin chromophore (4), ${ }^{4} \mathrm{C}-1027$ chromophore (5), ${ }^{5}$ and neocarzinostatin chromophore (6), ${ }^{6}$ derived from bacterial sources in the latter half of the $1980 \mathrm{~s}$ (Figure 1), and two new marine natural products, such as namenamicin $(7)^{7}$ and shishijimicins $(\mathbf{8 A}-\mathbf{D})^{8}$ reported in 1996 and 2003 respectively (Figure 2), have attracted a great deal of interest in chemical, biochemical, and medical research. This discovery marked the beginning of an exciting era in basic research toward new and potentially useful chemotherapeutic agents. Because of unprecedented and highly unusual molecular architecture containing a cyclic enediyne or related systems, fascinating mode of action, and excellent biological activities, these antitumor antibiotics have been widely investigated. ${ }^{9}$

Chemically, much research is focused mainly on the total synthesis of the natural enediynes and on the preparation of simple model compounds with analogous antitumor and antibiotic activity. Furthermore, the connection of biradical cycloaromatization protocols and subsequent radical cyclizations provides an exquisite approach to polycyclic ring systems. ${ }^{10}$ The thermal cycloaromatization of enediynes by the Bergman cyclization to afford reactive biradicals has been extensively investigated. ${ }^{9,11}$ Moreover, extensive investigations have also been focused on the thermal cycloaromatization of enyne-allenes by $\mathrm{C}^{2}-\mathrm{C}^{7}$ (Myers-Saito) cyclization ${ }^{11}$ or $\mathrm{C}^{2}-\mathrm{C}^{6}$ (Schmittel) cyclization, ${ }^{12}$ and enyne-ketenes by the Moore cyclization. ${ }^{11}$ In addition, these systems also attract considerable attention of the physical organic and theoretical chemists. $^{9 \mathrm{a}}$ 

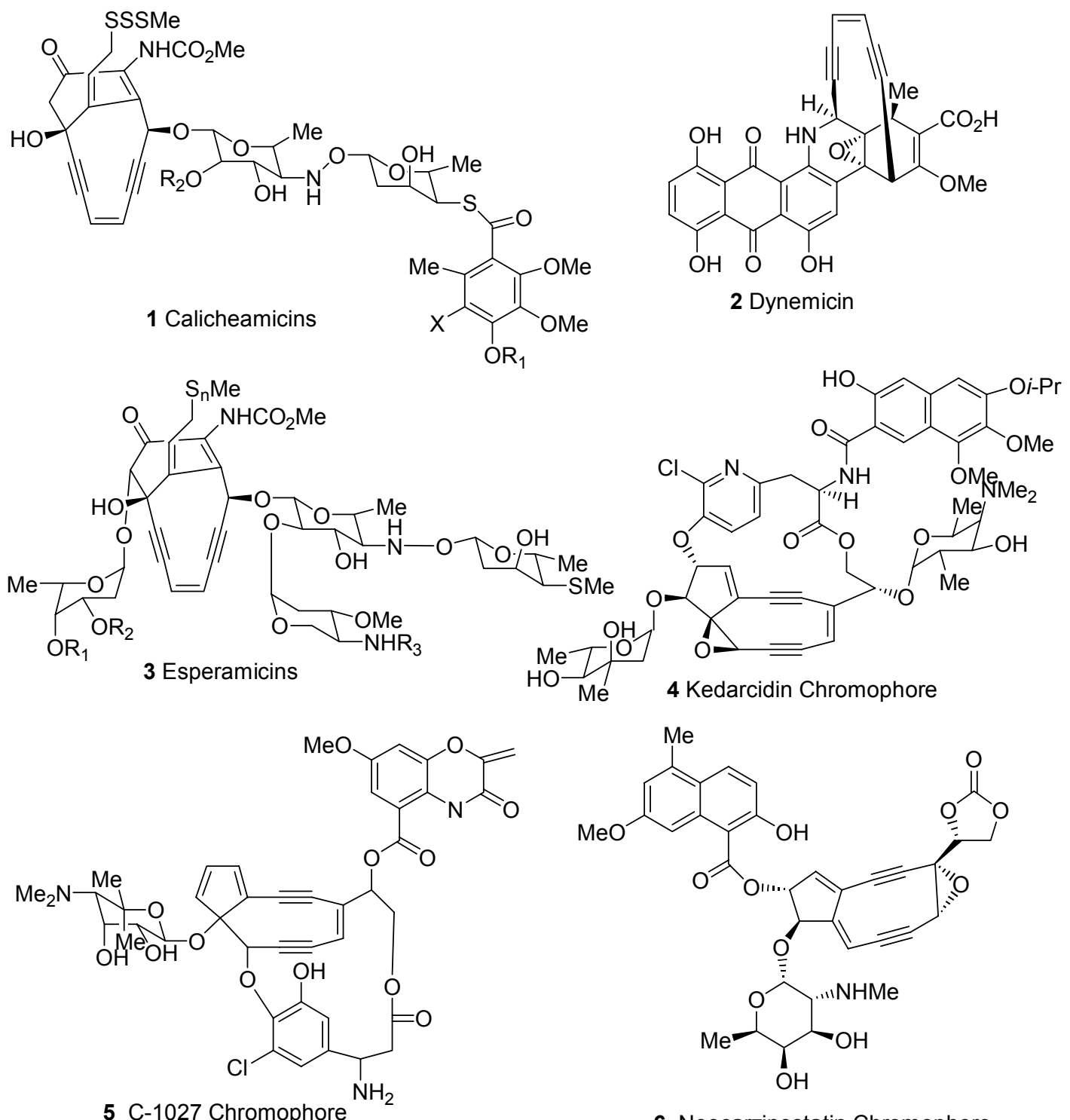

Figure 1. Structures of naturally occurring antitumor antibiotics from bacterial sources.

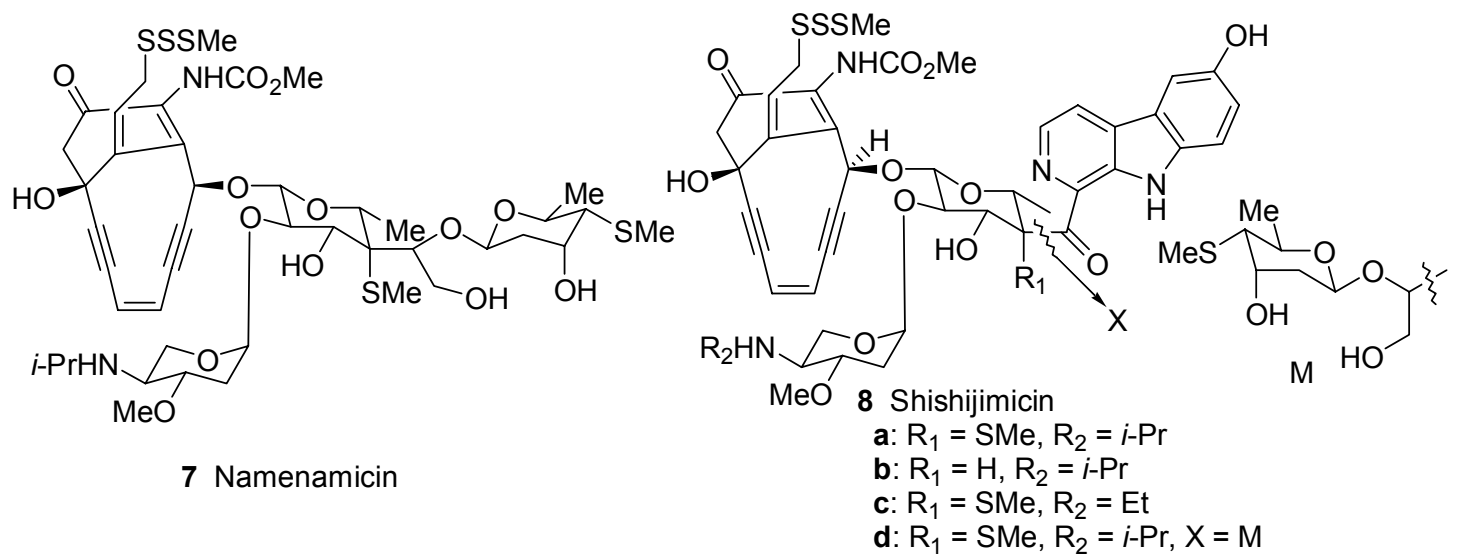

Figure 2. Structures of naturally occurring antitumor antibiotics from marine sources. 


\section{Biological Activities and DNA-Cleavage Mechanism of Enediyne Antitumor Antibiotics}

The natural enediyne antitumor antibiotics are one class of the most potent antitumor and antibacterial agents known. All of the naturally occurring enediynes are highly cytotoxic. ${ }^{9}$ Moreover, shishijimicin $(\mathbf{8 A})$ is almost 10 times more reactive than namenamicin $(7){ }^{8}$

The biological activity of these naturally occurring enediynes is attributed to their ability to cleave DNA irreversibly. Generally, selective DNA cleavage by the naturally occurring enediynes occurs in the following four steps: ${ }^{9 \mathrm{~b}}$

a. Recognizing and binding to the minor groove of DNA by a specific structural feature.

b. Activation of the cyclic enediyne toward the Bergman cyclization.

c. Bergman cyclization to produce 1,4-didehydroarene biradicals.

d. Abstraction of hydrogen atoms from the backbone of DNA by the 1,4-didehydroarene biradicals leading to DNA cleavage and cell death.

The following proposed mechanism accounts for their damaging action on DNA. ${ }^{1}$ Specifically, Calicheamicin $\gamma_{1}{ }^{\mathrm{I}}$ (1) binds to the minor groove of double helical DNA via oligosaccharide which is thought to be the molecule's main recognition and binding moiety. A nucleophile attacks the central sulfur atom of the trisulfide group, followed by intramolecularly attacking the $\alpha, \beta$-unsaturated ketone to form intermediate 9. A facile Bergman cyclization reaction affords the 1,4-didehydrobenzenoid biradical $\mathbf{1 0}$. This highly reactive biradical abstracts two hydrogen atoms from the backbone of DNA double strand to generate DNA radical, which proceeds to react with molecular oxygen leading to DNA cleavage and cell death, and an aromatic compound $\mathbf{1 1}$ (Scheme 1).

A similar mechanism was proposed to account for the action of NCS chromophore (6) by Myers. ${ }^{13}$ The DNA damage is initiated by stereospecific nucleophilic attack at $\mathrm{C} 12$, followed by 
rearrangement of the ring skeleton with epoxide opening and formation of a cumulene as a labile intermediate 12. A rapid Myers-Saito cyclization leads to biradical 13, followed by extraction of two hydrogen atoms from DNA resulting in the formation of $\mathbf{1 4}$ and DNA cleavage (Scheme 2).

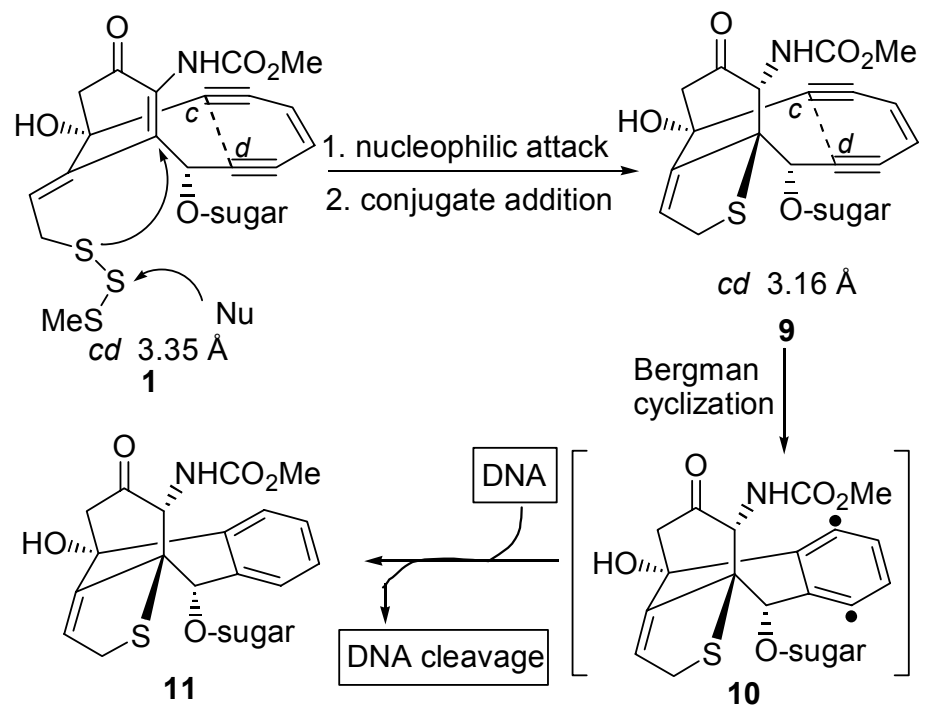

Scheme 1. Mechanism of DNA cleavage by 1 .

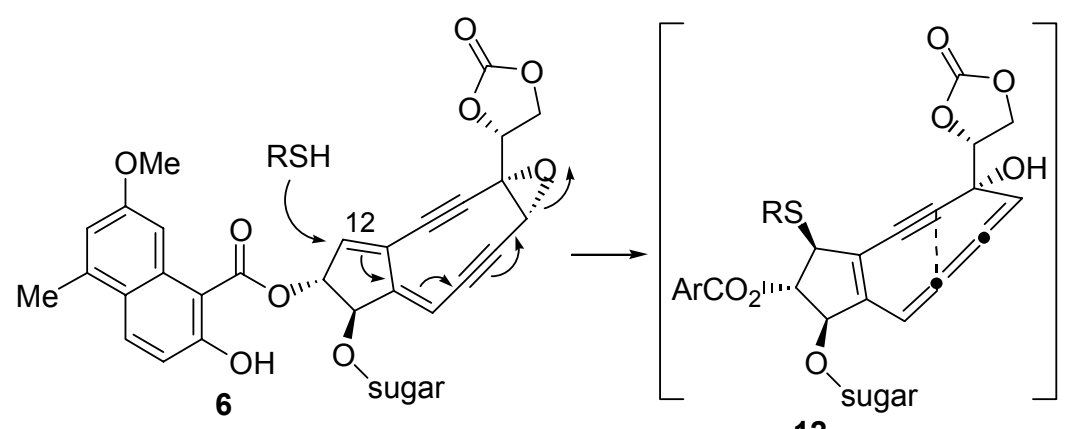

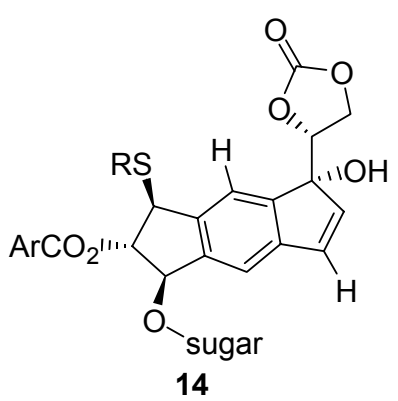

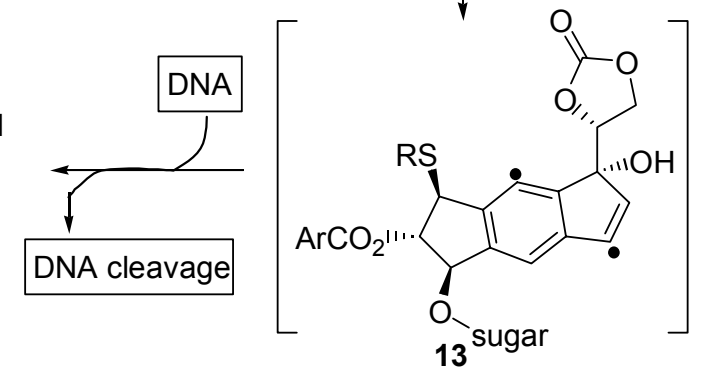

Scheme 2. Mechanism of DNA cleavage by $\mathbf{6}, \mathrm{RSH}=$ thionucleophile, $\mathrm{Ar}=$ naphthyl substituent. 


\section{Cyclization Reaction of Enediynes via Bergman Cyclization}

The chemistry of enediynes could date back to 1966 . Sondheimer reported the reaction from $\mathbf{1 5}$ to $\mathbf{1 7}$ and proposed a cyclization mechanism via an ionic intermediate $\mathbf{1 6}$ (Scheme 3). ${ }^{14}$
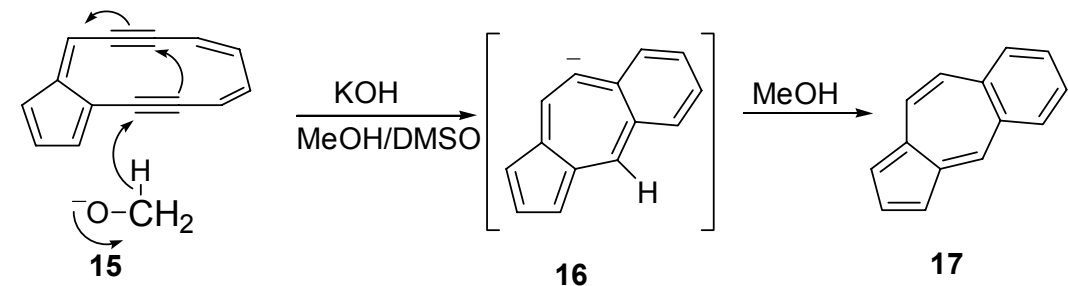

Scheme 3. Cyclization of $\mathbf{1 5}$ reported by Sondheimer.

In 1971, Masamune et al. reported the reaction of converting two cyclic enediynes $\mathbf{1 8}$ to the benzenoid systems 19, but without proposing the reaction via a biradical intermediate (Scheme 4). ${ }^{15}$

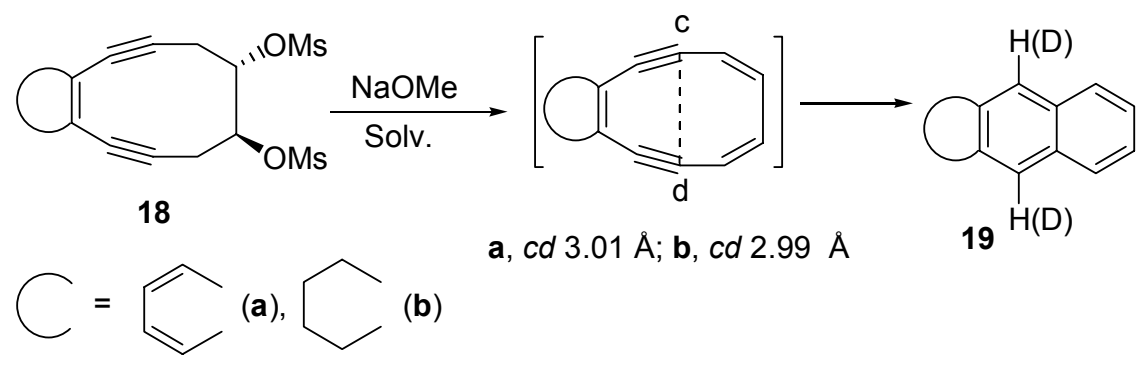

Scheme 4. Cyclization of enediyne observed by Masamune, Ms = mesyl.

In 1972, Bergman published his detailed study on the cycloaromatization of enediynes. ${ }^{16}$ He first proposed 1,4-didehydrobenzene biradical as a key intermediate for the cyclization reaction of enediynes. As a good indirect evidence of the Bergman cyclization via a biradical intermediate, when $\mathbf{2 0}$ was heated in solution, the observed products were benzene or its derivative 22 via the biradical intermediate 21, depending on the solvents used (Scheme 5). ${ }^{17}$

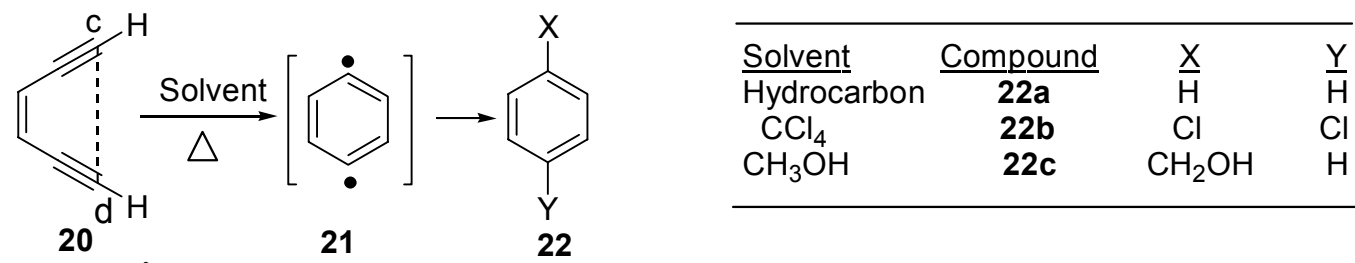

cd $4.12 \AA$

Scheme 5. The Bergman cyclization of $\mathbf{2 0}$ in a variety of solvents. 
The reactivity of $(Z)$-enediyne in the Bergman cyclization is affected by the following important factors including: 1) the $c d$ distance, which is the distance between the two terminal acetylenic carbon atoms; 2) the difference in strain energy between the enediyne and the transition state; 3) the concentration of the trapping agent; and 4) substituent effects. Several studies related to these effects on the reactivity of enediynes toward the Bergman cyclization were published. $^{9 \mathrm{~b}}$

Based on Nicolaou et al.'s model study on 10-membered cyclic, strain-free enediyne systems, the upper limit of $c d$ distance required for the Bergman cyclization at a measurable rate at ambient temperature is $3.2-3.3 \AA .^{18}$ These pioneering studies show that the 10 -membered cyclic enediynes are optimal for the Bergman cyclization. The relationship of the reactivity of enediynes with $c d$ distance is summarized in Table 1.

Magnus and Snyder, using different methods, found independently that the critical factor determining the reactivity of strained enediynes is not the $c d$ distance but the difference in strain energy between the enediyne and the transition state leading to the biradical intermediate. ${ }^{9 \mathrm{c}}$ Scheme 6 outlines the result of Magnus. ${ }^{20}$ They found that 23B is more reactive.

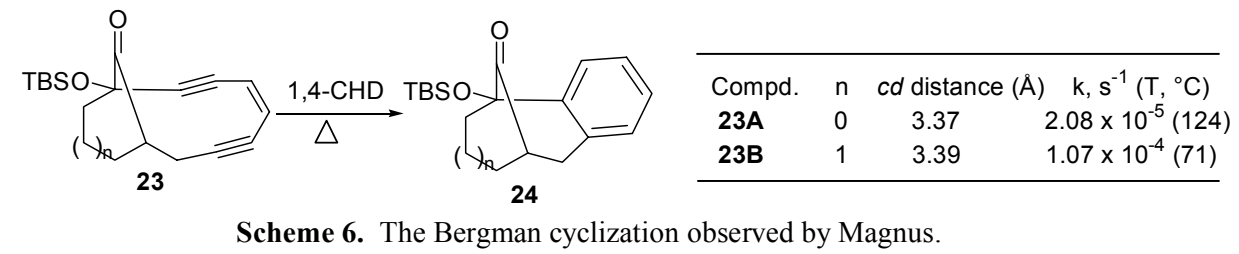

Semmelhack et al. reported the dependence of the Bergman cyclization rate on the concentration of trapping agents. They found that the reactivity of $\mathbf{2 5}$ to produce $\mathbf{2 6}$ depends on the concentration of 1,4-cyclohexadiene (1,4-CHD) (Scheme 7). ${ }^{21}$

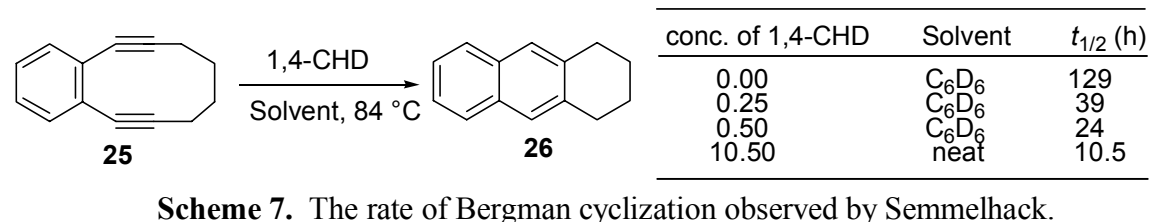


Table 1. Calculated $c d$ Distance and Stabilities of Conjugated Enediynes

\begin{tabular}{|c|c|c|c|c|c|}
\hline Entry & Compound & Ring Size & $c d$ Distance $[\AA]$ & Stability & Ref. \\
\hline 1 & & 9 & 2.84 & unknown compound & $19 a$ \\
\hline 2 & & 10 & 3.25 & $t_{1 / 2}=18 \mathrm{~h}$ at $37^{\circ} \mathrm{C}$ & $19 a$ \\
\hline 3 & & 10 & 3.20 & $t_{1 / 2}=11.8 \mathrm{~h}$ at $37^{\circ} \mathrm{C}$ & $19 b$ \\
\hline 4 & & 10 & 3.03 & cyclized at $25^{\circ} \mathrm{C}$ & $19 c$ \\
\hline 5 & & 10 & 3.01 & cyclized $<25^{\circ} \mathrm{C}$ & 15 \\
\hline 6 & & 10 & 2.99 & cyclized $<25{ }^{\circ} \mathrm{C}$ & 15 \\
\hline 7 & & 11 & 3.61 & stable at $25^{\circ} \mathrm{C}$ & $19 a$ \\
\hline & & 12 & 3.77 & stable at $25^{\circ} \mathrm{C}$ & $19 d$ \\
\hline 9 & & - & 4.12 & $\begin{array}{l}\text { stable at } 25^{\circ} \mathrm{C} ; \\
t_{1 / 2}=30 \mathrm{~s} \text { at } 200^{\circ} \mathrm{C}\end{array}$ & $16 a$ \\
\hline 10 & & - & 3.94 & $\begin{array}{l}\text { stable at } 25^{\circ} \mathrm{C} \text {; } \\
k_{\text {obs }}=6.4 \times 10^{-4} \mathrm{~s}^{-1} \\
\text { at } 156^{\circ} \mathrm{C}\end{array}$ & $19 e$ \\
\hline
\end{tabular}

Although complete systematic effects of substituents on the reactivity of enediynes were not reported, this reactivity seemed to be sensitive to both electronic and steric effects of substituents. $^{9 \mathrm{~b}}$ Generally, cyclic enediynes containing benzo or quinone in the ene portion are more reactive than acyclic enediynes. Furthermore, the enediynes containing quinone are much 
more reactive (Table 2). ${ }^{21 \mathrm{~b}}$ Alabugin et al. found that the Bergman cyclization of aromatic enediynes is sensitive to ortho substitution as a result of a combination of electronic, steric, and electrostatic effects. ${ }^{22}$ Benzannulated enediynes with ortho substituents, such as $\mathrm{CH}_{3}, \mathrm{NH}_{2}$, and $\mathrm{OH}$, have high activation energy; the large decrease in the activation energy upon protonation has been discovered, which is important because cancer cells are more acidic than normal cells. This discovery provides possibilities for DNA-cleavage drug design.

Table 2. Effects of Substituents on the Reactivity of Enediynes

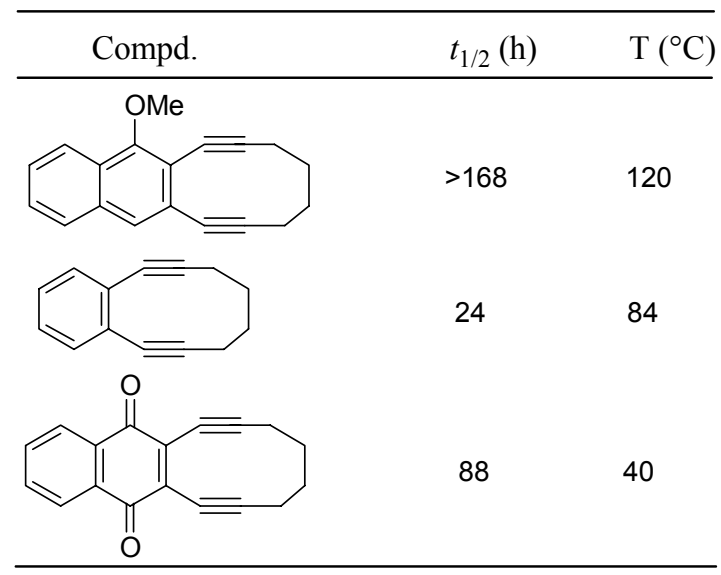

To explore the potential of using simple enediynes as DNA-cleavage drug, some research interests extended to develop the convenient method to suppress or activate cyclization. Turro and Nicolaou et al. first reported the photo-induced cyclization of an enediyne as a mild alternative to thermolysis, which could avoid high temperature to activate the Bergman cyclization (Scheme 8). ${ }^{23 a}$ A similar mechanism to that of thermal cyclization was proposed. The more extensive investigation of the photochemically activated Bergman cyclization was reported by Funk et al. ${ }^{23 \mathrm{~b}}$ and Zaleski et al. ${ }^{23 \mathrm{c}}$

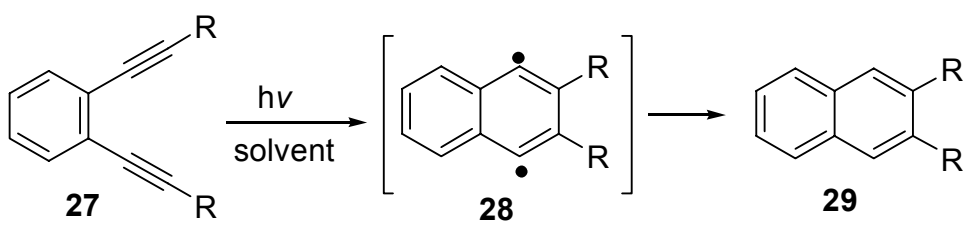

Scheme 8. Photo-induced Bergman cyclization, $\mathrm{R}=n$-Pr. 
The remarkable reactivity of the enediynes has facilitated efforts toward the exploitation of the 1,4-didehydroarene biradical intermediate for therapeutic applications. The capacity of initiating and controlling the reactivity of enediynes is important for the realization of such goals. Transition metals were reported to both stabilize and activate enediynes toward thermally initiated Bergman cyclization, depending on two common factors: the conformational flexibility of the enediyne ligand coordinated to the metal ion and the specific geometry of the chelated metalloenediyne complex. ${ }^{23 \mathrm{c}}$ Buchwald et al. reported a controlled acceleration and inhibition of the Bergman cyclization by metal chlorides. ${ }^{24}$ The enediyne-based biphenylphosphine 30, upon coordination to palladium or platinum dichloride, underwent a Bergman cyclization at a greatly enhanced rate at relatively low temperature (Scheme 9).

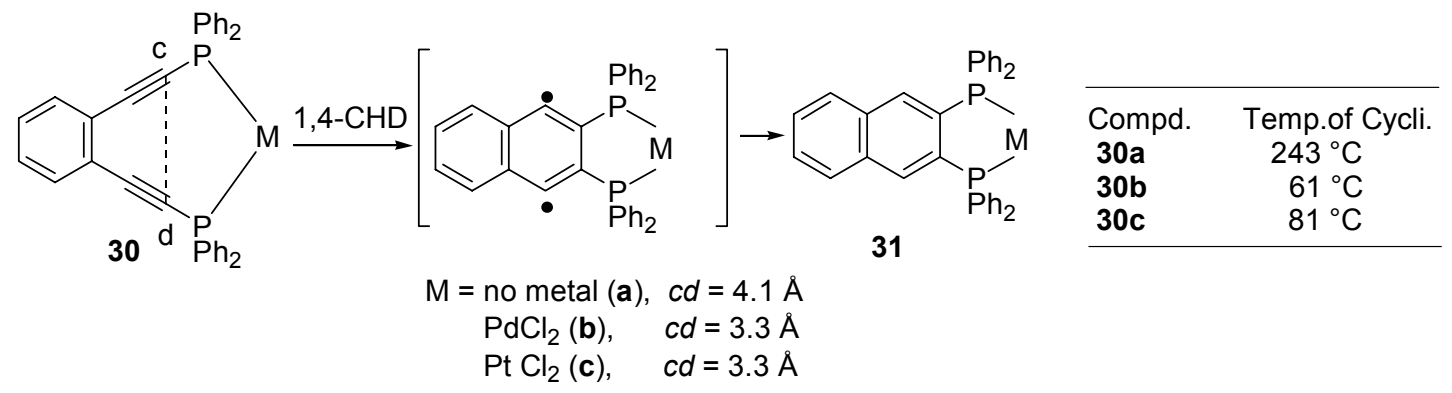

Scheme 9. The Bergman cyclization accelerated by metal chlorides.

Since this pioneering work, more examples of metal-assisted thermal enediyne cyclization have been reported to demonstrate the utility of transition metals for controlling enediyne cyclization. $^{25}$ Investigation of several metal ions, such as $\mathrm{Cu}(\mathrm{I}), \mathrm{Cu}(\mathrm{II}), \mathrm{Ni}(\mathrm{II}), \mathrm{Pd}(\mathrm{II})$, $\mathrm{Pt}(\mathrm{II}), \mathrm{Ru}$, and $\mathrm{Mg}^{2+}$, provides both theoretical and practical advances in the ability to control the Bergman cyclization. ${ }^{26}$ Zaleski et al. reported that enediyne ligands could be activated by using $\mathrm{Mg}^{2+}$ salts, a biologically prevalent and innocuous metal ion. ${ }^{26 \mathrm{c}}$ They found that compound 32 would cyclize at $100{ }^{\circ} \mathrm{C}$, but was stable at room temperature. However, as a result of decreasing 
$c d$ distance and coordination effect, complex $\mathbf{3 3}$ could cyclize at room temperature (Scheme $10) .^{26 \mathrm{c}}$

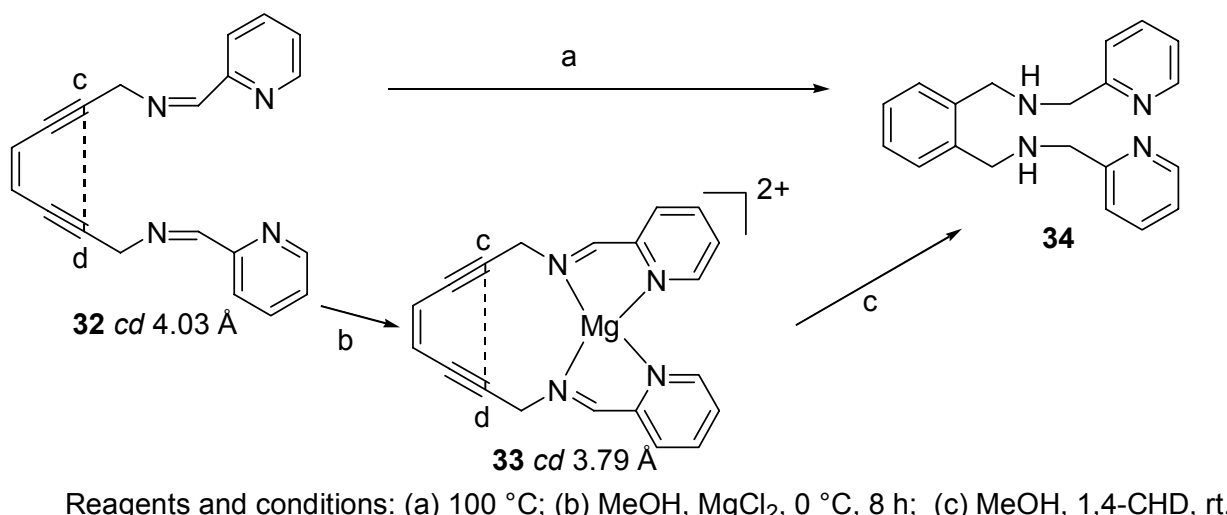

Scheme 10. The Bergman cyclization accelerated by $\mathrm{Mg}^{2+}$.

\section{Cyclization Reaction of Enyne-Allenes}

\subsection{Myers-Satio $\left(C^{2}-C^{7}\right)$ Cyclization}

In the investigation of conjugated unsaturated structures that could cyclize via biradical intermediates at mild conditions and possess promising DNA-cleaving activity, Myers ${ }^{27}$ and Saito's $^{28}$ group reported a new variant of the Bergman type cyclization with the parent system (Z)-1,2,4-heptatrien-6-yne (35) (Scheme 11) in 1989, respectively. This cycloaromatization was recognized as Myers-Saito cyclization, also termed as the $\mathrm{C}^{2}-\mathrm{C}^{7}$ cyclization, which proceeds via $\alpha, 3$-didehydrotoluene biradical (36) leading to toluene (37) upon hydrogen atom abstraction. As evidence of the cyclization via a biradical mechanism, thermolysis of acyclic enyne-allene $\mathbf{3 5}$ in various solvents was studied. The result is summarized in Figure 3. Moreover, Myers found the reaction is a first-order reaction with the following activation parameters: $\Delta H^{\ddagger}=21.8 \pm 0.5$ $\mathrm{kcal} / \mathrm{mol}, \Delta S^{\ddagger}=-11.6 \pm 1.5 \mathrm{cal} \mathrm{K}^{-1} \mathrm{~mol}^{-1}\left(E_{\mathrm{a}}=22.5 \mathrm{kcal} / \mathrm{mol}, \log A=10.7\right)$. Although the Bergman cyclization and the Myers-Saito cyclization are related, the ground state of $\mathbf{3 6}$ is most likely a $\sigma, \pi$-biradical, whereas that of $\mathbf{2 1}$ is almost constrained as a $\sigma, \sigma$-biradical, and the former 
is more stable. In addition, the $c d$ distance of enyne-allenes is shorter than that of enediynes. Therefore, the Myers-Saito cyclization is more facile and strongly exothermic $(\Delta H \approx-15 \pm 3$ $\mathrm{kcal} / \mathrm{mol})$, whereas the Bergman cyclization is modestly endothermic $(\Delta \mathrm{H} \approx 14 \mathrm{kcal} / \mathrm{mol})$.

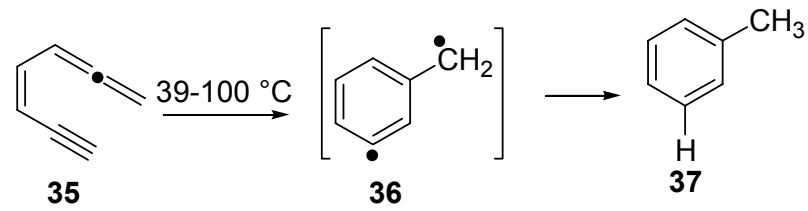

Scheme 11. The Myers-Saito cyclization.

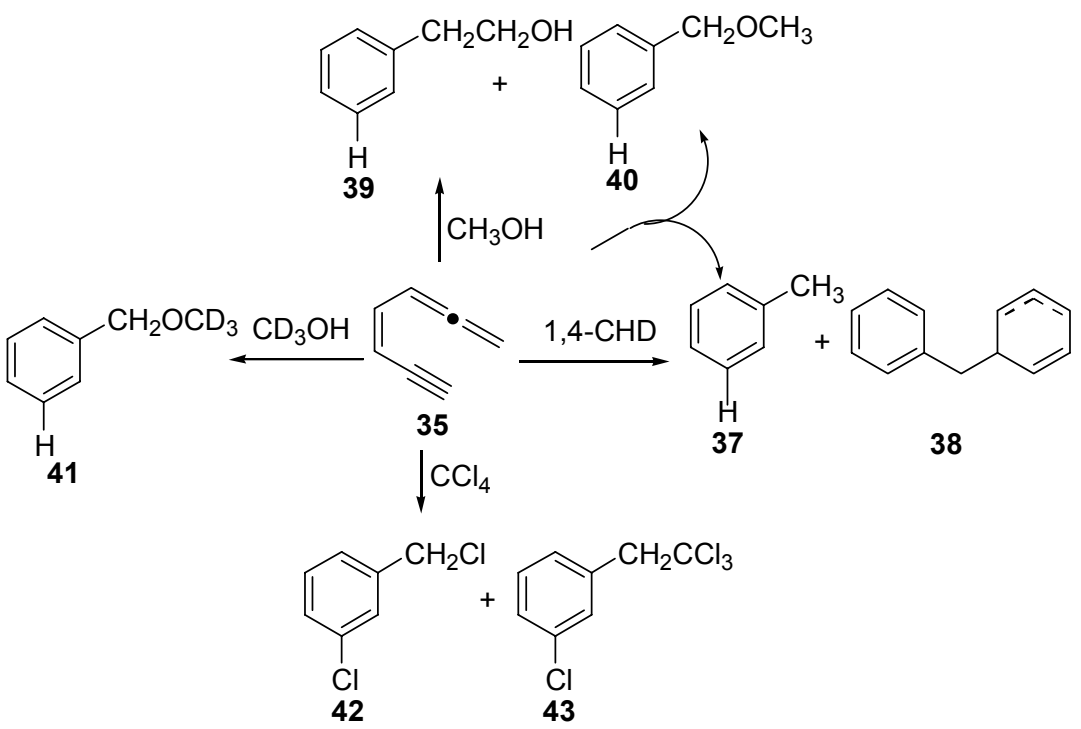

Figure 3. Products of thermolysis of (Z)-1,2,4-heptatrien-6-yne (35) in various solvents.

Saito et al. demonstrated the chemistry of the $\mathrm{C}^{2}-\mathrm{C}^{7}$ cyclization and the DNA cleavage activity based on a series of simple model molecules, which were readily constructed and cyclized at body temperature with DNA cleavage activities (Scheme 12). ${ }^{28}$ The intriguing possibilities of developing analogs of antitumor antibiotics based on enyne-allene system might be realized by further modification of the structures.

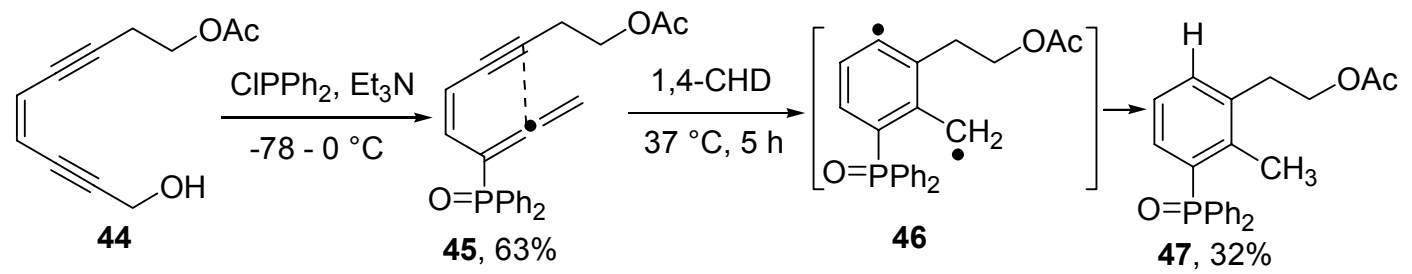

Scheme 12. The Myers-Saito cyclization observed by Saito et al. 


\subsection{Schmittel $\left(C^{2}-C^{6}\right)$ Cyclization}

With the extensive investigation of thermal cyclization of enyne-allenes, most of them result in the formation of six-membered rings through the $C^{2}-C^{7}$ pathway. However, in 1995, Schmittel et al. reported their surprising discovery that some of the masked enyne-allene model systems exhibit a novel thermal cyclization model via the $C^{2}-C^{6}$ pathway by replacing the hydrogen at the acetylene terminus with an aryl group or a sterically bulky group $(\mathrm{R}=t \mathrm{Bu}$ or TMS). ${ }^{12}$ The proposed mechanism of the switch from the $C^{2}-C^{7}$ to the novel $C^{2}-C^{6}$ cyclization is outlined in Scheme $13 .^{29}$ This novel $C^{2}-C^{6}$ cyclization involves a very short-lived benzofulvene biradical intermediate 51 (lifetime $<10^{-8} \mathrm{~s}$ ). The aryl group could stabilize the vinyl radical, therefore this stabilizing effect favors the formation of biradical $\mathbf{5 1}$ over biradical 49. Moreover, the steric effect is more significant in the biradical intermediate of $\mathrm{C}^{2}-\mathrm{C}^{7}$ cyclization than the benzofulvene biradical of $\mathrm{C}^{2}-\mathrm{C}^{6}$ cyclization. $^{29 f}$ As a result, with $\mathrm{R}^{1}=\mathrm{H}$, the thermal cyclization leads to the Myers-Saito cycloaromatization product 50 in the presence of 1,4cyclohexadiene (1,4-CHD), whereas with $\mathrm{R}^{1}=p$ Tol, the thermal cyclization leads to the formal ene product 52 or the formal Diels-Alder product 53d and 54c depending on the nature of the group $\mathrm{R}^{2}$.

Although all attempts to trap the postulated biradical intermediate were unsuccessful, the stepwise mechanism is based on the following evidence: $\left.{ }^{10,29 a} 1\right)$ The activation barriers for the formal ene and the Diels-Alder reaction are very similar. In addition, the activation barriers for the enyne-allenes with different aryl substitutes are almost identical. If the mechanism were a concerted reaction, the activation energy of $\mathbf{4 8 d}$ would be much higher than that of $\mathbf{4 8 c}$. Moreover, there was no example of mesitylene analogs undergoing the Diels-Alder reaction leading to cycloadducts across a mesitylene ring even under extreme conditions. 2) Polarity of 
the solvents such as mesitylene, benzene, and DMSO, does not affect the reaction rate of the cyclization. 3) The similar DNA cleavage activity as the biradical intermediate of the Myers-Saito cyclization was demonstrated by the formation of the open circular DNA. ${ }^{29, g}$

Theoretical calculation studies also support the biradical mechanism with the formation of the biradical intermediate being the rate-determining step. ${ }^{30}$

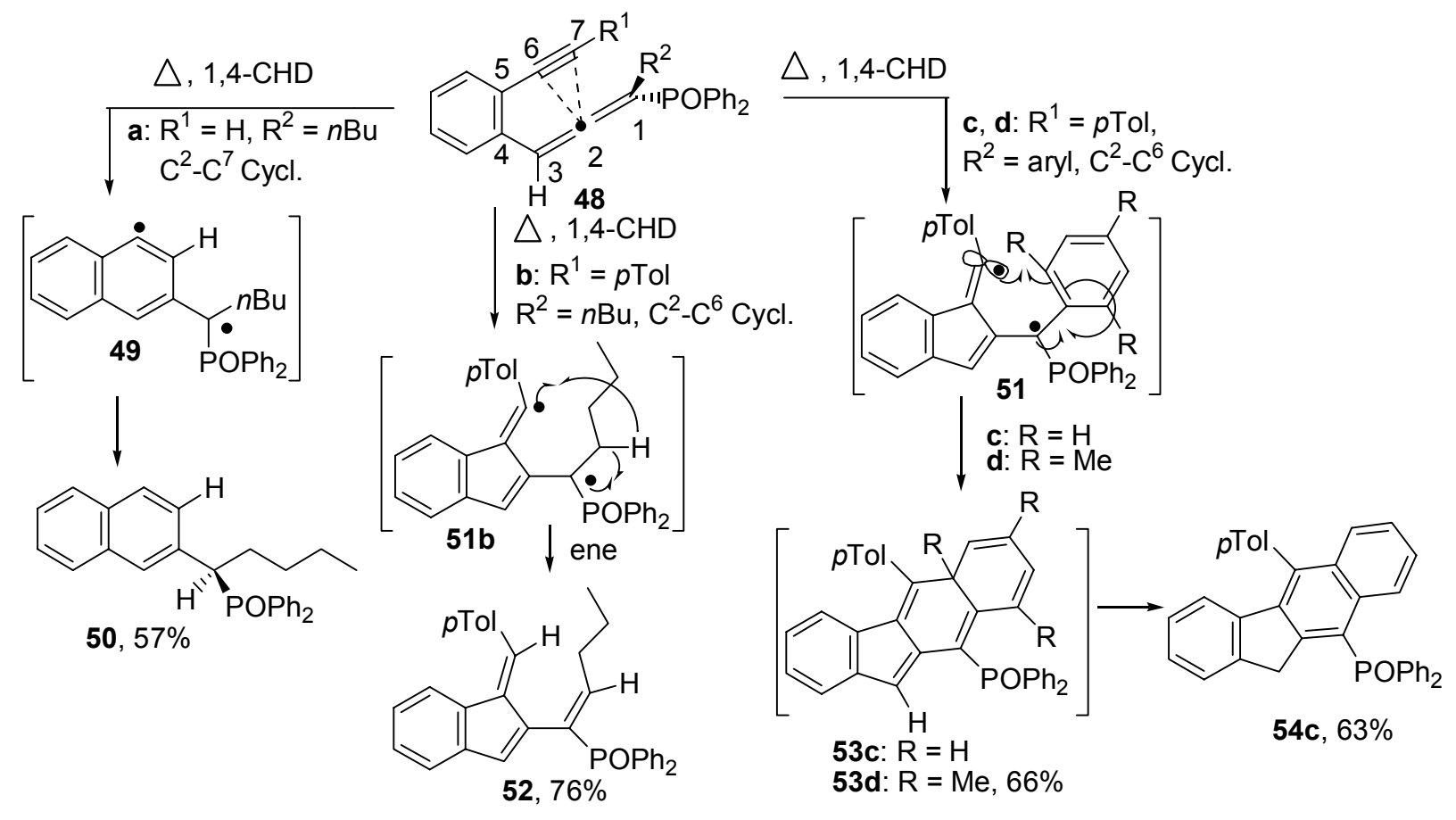

Scheme 13. Switch from the $C^{2}-C^{7}$ cyclization to the $C^{2}-C^{6}$ cyclization.

\subsection{Construction of Polycyclic Ring Systems via Cycloaromatization of Enyne-Allenes}

The current research on the thermal biradical cyclization of enediynes, enyne-cumulenes, and enyne-allenes is not only focused on the synthesis of model compounds with similar analogous antitumor antibiotic activity as the natural enediynes, but also on employing the high potential of the cycloaromatization reaction for the construction of polycyclic ring systems.

In addition to the theoretical and mechanistic study of the Myers-Saito and the Schmittel cyclization reactions, the Myers-Saito and the Schmittel cyclizations were employed to construct 
novel ring systems. If an aryl group is placed at the allenic terminus, the enyne-allene could undergo the $\mathrm{C}^{2}-\mathrm{C}^{6}$ cyclization producing a fulvene/benzofulvene biradical followed by a rapid intramolecular radical-radical coupling reaction leading to the formal Diels-Alder product (Scheme 14). ${ }^{31}$

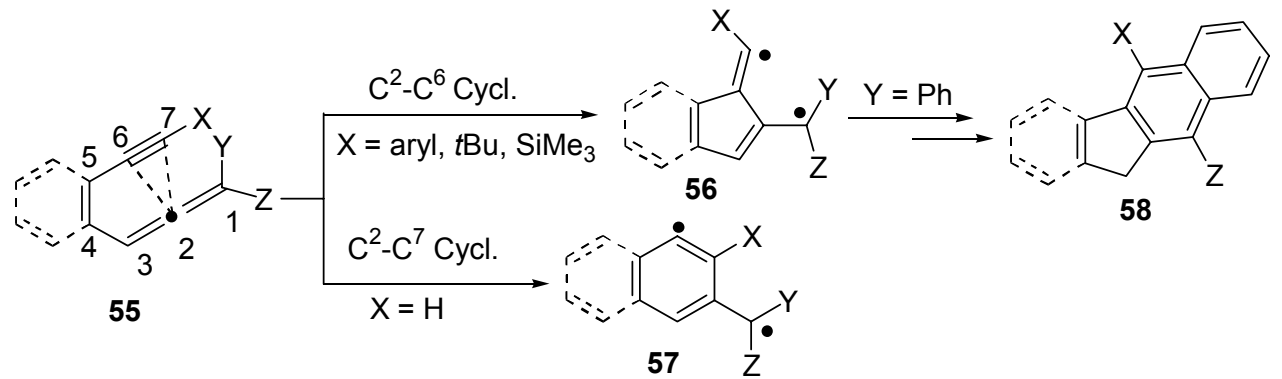

Scheme 14. Application of the $C^{2}-C^{6}$ cyclization to construct novel ring systems.

Dr. Hai-Ren Zhang developed a new synthetic pathway to generate the chlorosubstituted benzannulated enyne-allenes in situ via a $\mathrm{S}_{\mathrm{N}} \mathrm{i}^{1}$ reaction promoted by thionyl chloride. The subsequent rapid cascade radical cyclization and tautomerization lead to novel polycyclic ring systems. ${ }^{32}$ This pathway was adopted for the synthesis of a $\mathrm{C}_{44} \mathrm{H}_{26}$ hydrocarbon (Scheme 15) ${ }^{32 \mathrm{a}}$ and other polycyclic aromatic hydrocarbons.
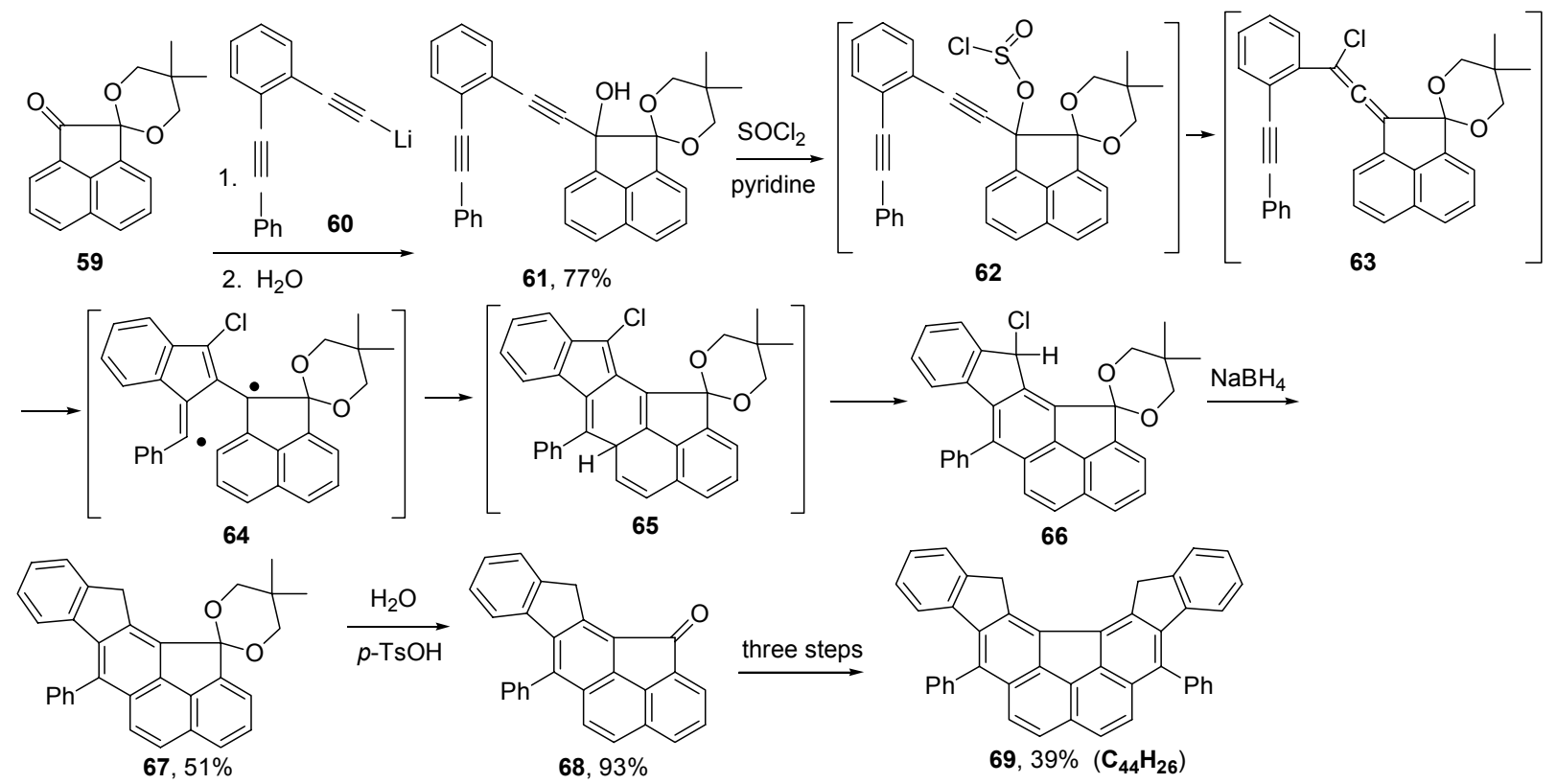

Scheme 15. Synthesis of a $\mathrm{C}_{44} \mathrm{H}_{26}$ hydrocarbon via benzannulated enyne-allene. 
Dr. Hongbin Li developed a new synthetic pathway to the benzannulated enyne-allenes without a chloro-substituent, followed by similar cyclization and tautomerization leading to the corresponding polycyclic aromatic hydrocarbons directly (Scheme 16). ${ }^{32 \mathrm{~b}}$ This strategy was adopted for the preparation of twisted 4,5-diarylphenanthrenes (Scheme 17), ${ }^{33}$ polycyclic hydrocarbons, ${ }^{32 b}$ and helical hydrocarbons. ${ }^{34}$

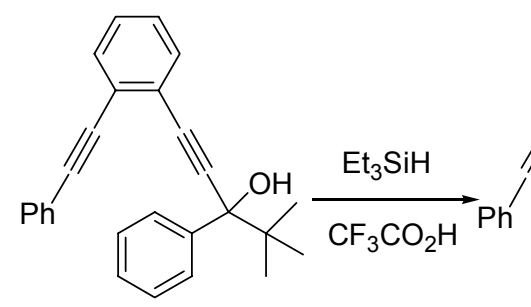

70

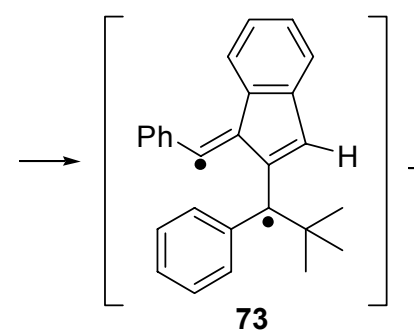

73

Scheme 16. A new synthetic pathway to the benzannulated enyne-allene and polycyclic hydrocarbon.

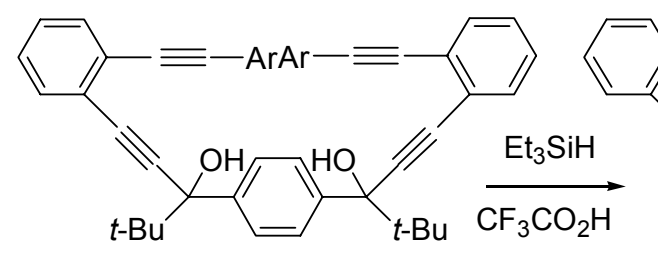

76a: $\mathrm{Ar}=\mathrm{Ph}$

76b: $\mathrm{Ar}=4$-biphenylyl

76c: $\mathrm{Ar}=3,5-$ dimethylphenyl

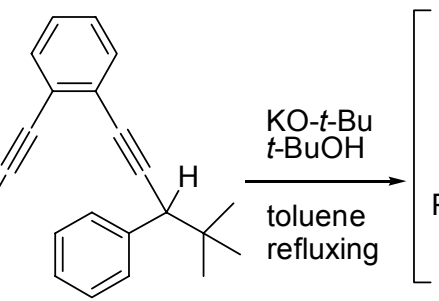

71, $96 \%$

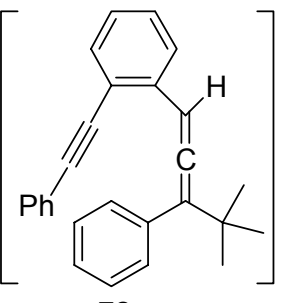

72

Scheme 17. Synthesis of 4,5-diarylphenanthrenes via benzannulated enyne-allenes.

The Gillmann group ${ }^{35 a}$ and Rodriguez group ${ }^{35 b}$ reported their discovery of a potential stepwise biradical process for the formal $[2+2]$ cyclization reaction (Scheme 18). ${ }^{35 \mathrm{a}}$

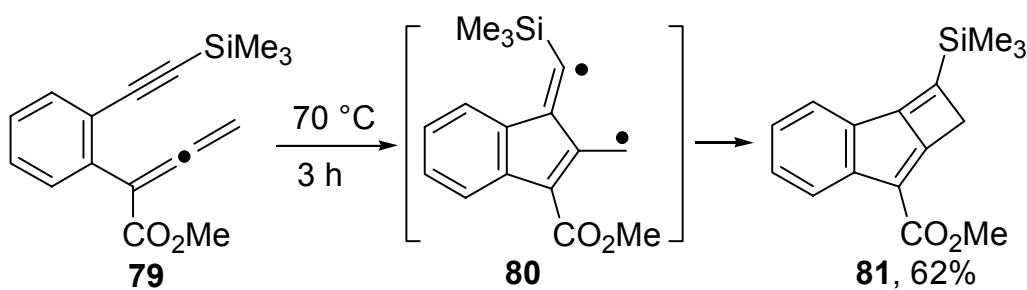

Scheme 18. Gillmann's observation of formal $[2+2]$ cycloaddition. 
Lipton et al. reported a new type of benzannulated enyne-allene that could cyclize at a faster rate via oxyanion than nearly all known examples leading to new polycyclic compounds (Scheme 19). ${ }^{36}$ The $\mathrm{C}^{2}-\mathrm{C}^{6}$ cyclizations were promoted by methyllithium at $-20{ }^{\circ} \mathrm{C}$.

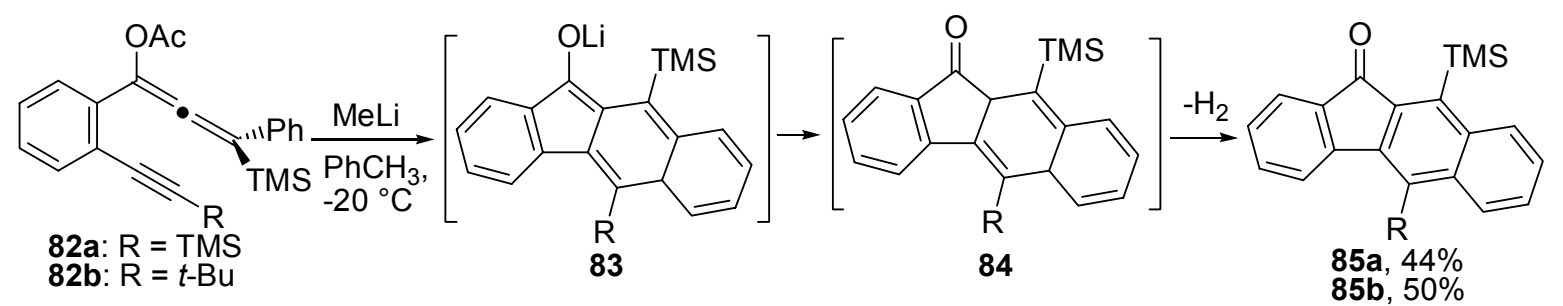

Scheme 19. Lipton's result of the enyne-allene cyclization via oxyanion.

In addition to the polycyclic hydrocarbons, some heterocyclic compounds were prepared via the cycloaromatization. Shibuya's group reported their discovery of $\mathrm{pH}$ dependent cycloaromatization of enediyne model compounds via enyne-allene intermediates leading to heterocyclic products promoted by trifluoroacetic acid (Scheme 20). ${ }^{37}$

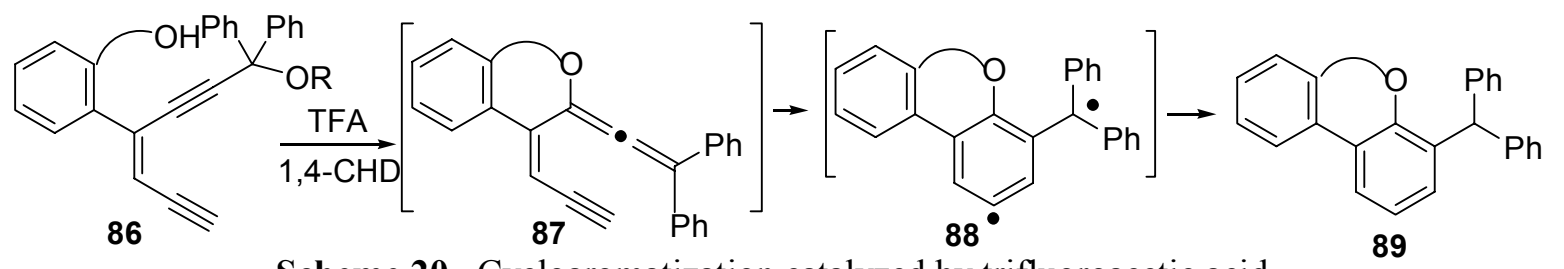

Scheme 20. Cycloaromatization catalyzed by trifluoroacetic acid.

\subsection{Cyclization Reaction of Hetero Enyne-Allenes and Their Applications to the Synthesis of Novel Heterocyclic Ring Systems}

In addition to the thermal cyclization of carbon enyne-allenes, the thermal cyclization of hetero enyne-allenes has also attracted considerable interests. The synthetic applications of the biradical intermediates could be further expanded if the $\mathrm{CH}_{n}$ groups in the enyne-allene system are replaced by heteroatoms. ${ }^{38}$ Indeed, enyne-ketenes $(\mathrm{A}=$ carbon, $\mathrm{B}=$ oxygen $)$ were reported to undergo the $C^{2}-C^{7}$ and the $C^{2}-C^{6}$ cyclizations by Moore et al. (Scheme 21$)^{39}$ leading to quinones or its derivatives; this reaction was termed as the Moore cyclization. By placing a 
phenyl group at the acetylenic terminus, the cyclizations are directed mainly toward the $C^{2}-C^{6}$ cyclization pathway instead of the $\mathrm{C}^{2}-\mathrm{C}^{7}$ cyclization route.

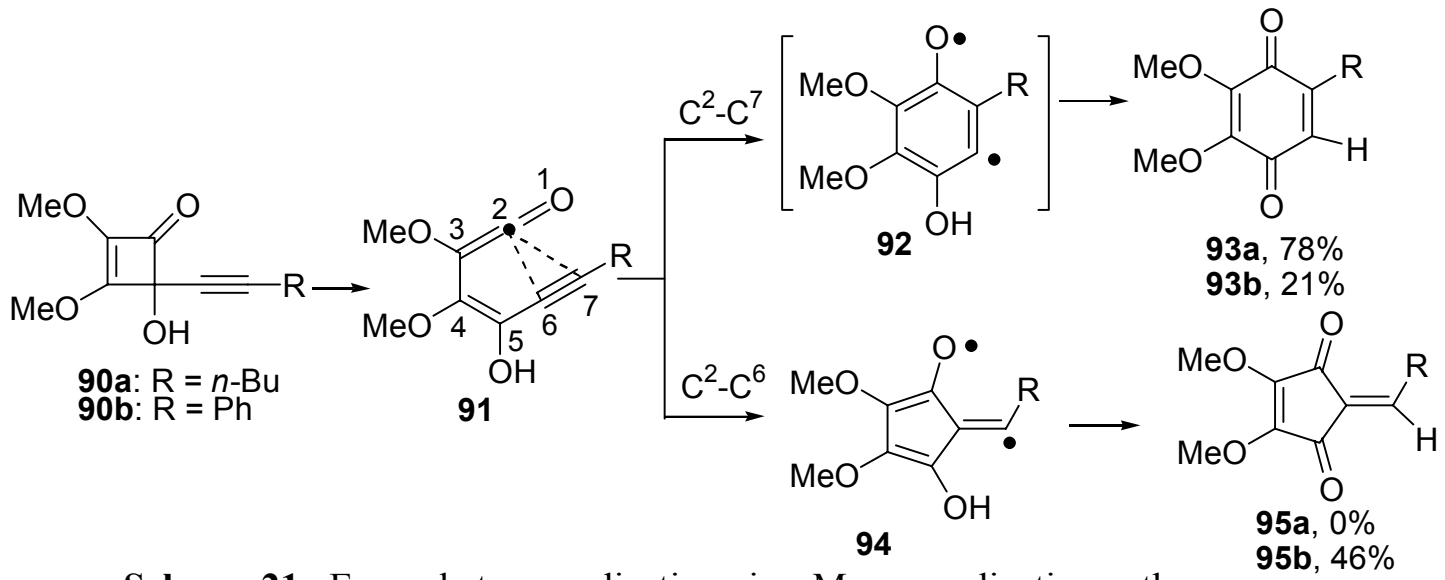

Scheme 21. Enyne-ketene cyclization via a Moore cyclization pathway.

Schmittel et al. reported their results concerning the cyclization of enyne-ketenimines (A $\left.=\mathrm{N}, \mathrm{B}=\mathrm{CR}^{\prime} \mathrm{R}^{\prime \prime}\right)$ and enyne-carbodiimides $\left(\mathrm{A}=\mathrm{N}, \mathrm{B}=\mathrm{NR}^{\prime}\right)$ and their synthetic potentials. ${ }^{40}$ These systems undergo the $C^{2}-C^{7}$ and the $C^{2}-C^{6}$ cyclizations as a function of substituents at the acetylenic terminus. With an aryl group, the reaction follows the $C^{2}-C^{6}$ cyclization pathway, whereas with a hydrogen atom, the reaction follows the $C^{2}-C^{7}$ cyclization pathway (Scheme 22).

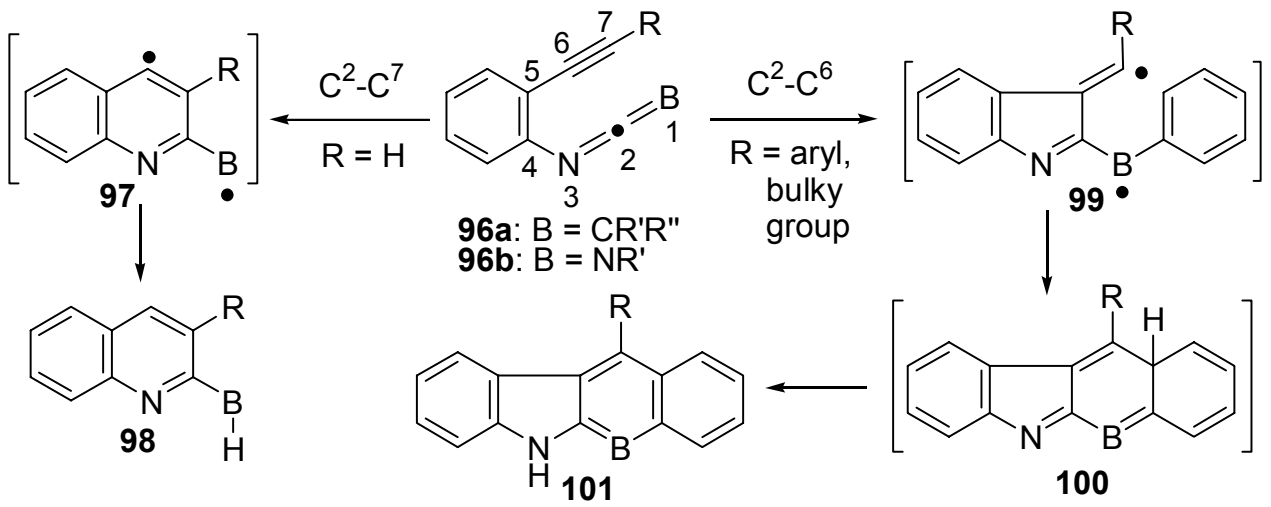

Scheme 22. $C^{2}-C^{7}$ and $C^{2}-C^{6}$ cyclization of hetero enyne-allenes.

Our group developed new methods of generating enyne-ketenimines and enyne-carbodiimides via the aza-Wittig reaction. Moreover, these new synthetic methods were adopted for the synthesis of several novel heterocyclic ring systems with structures similar to 
those of the naturally occurring ellipticine and its derivatives and other more complex structures by modification of R', R", or benzo moiety. ${ }^{41}$

In conclusion, the thermal cyclization of enyne-allenes and hetero enyne-allenes provides many opportunities for the construction of a variety of novel polycyclic ring systems including hydrocarbons and heterocyclic compounds. This strategy is one of the most convenient pathways to construct complex ring systems in a single operation.

\section{Literature Survey on the Synthetic Methodologies for the Preparation of Benzannulated}

\section{Enyne-Allenes and Acyclic Enyne-Allenes}

To further investigate the cyclization reaction of enyne-allenes, several synthetic methods were developed to prepare enyne-allenes with diverse structural features.

Enyne-allenes can be obtained by using the [2,3] sigmatropic rearrangement of propargylic phosphite or phosphinite to form allenyl phosphonate or phosphine oxide; this scheme was first reported by Sevin et al. in $1967 .^{42}$ This synthetic method was adopted by Saito, ${ }^{28}$ Nicolaou, ${ }^{43}$ Grissom, ${ }^{44}$ and Schmittel $^{29}$ for the preparation of enyne-allenes. For example, Nicolaou et al. reported that propargylic alcohol 102 was treated with chlorodiphenylphosphine in methylene chloride at $-78^{\circ} \mathrm{C}$ in the presence of triethylamine to produce allenyl phosphine oxide 104 in good yield (Scheme 23).

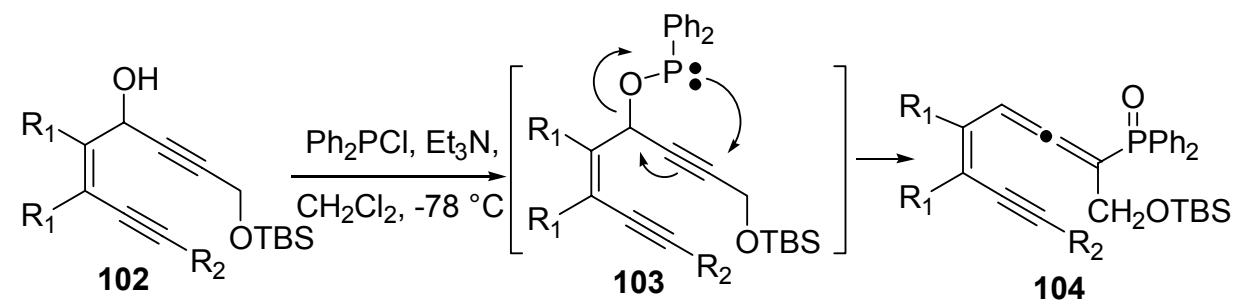

Scheme 23. Synthesis of enyne-allenes via [2,3] sigmatropic rearrangement by Nicolaou.

Grissom et al. reported a synthetic pathway to enyne-allenes via thermolysis of propargyl vinyl ethers to promote the [3,3] sigmatropic Claisen rearrangement at $150{ }^{\circ} \mathrm{C}$. ${ }^{44,45}$ 
They also discovered that the corresponding Lewis acid-catalyzed [3,3] sigmatropic Claisen rearrangement promoted by $\mathrm{AgBF}_{4}$ for the preparation of the benzannulated enyne-allenes could be carried out at room temperature (Scheme 24). ${ }^{44}$

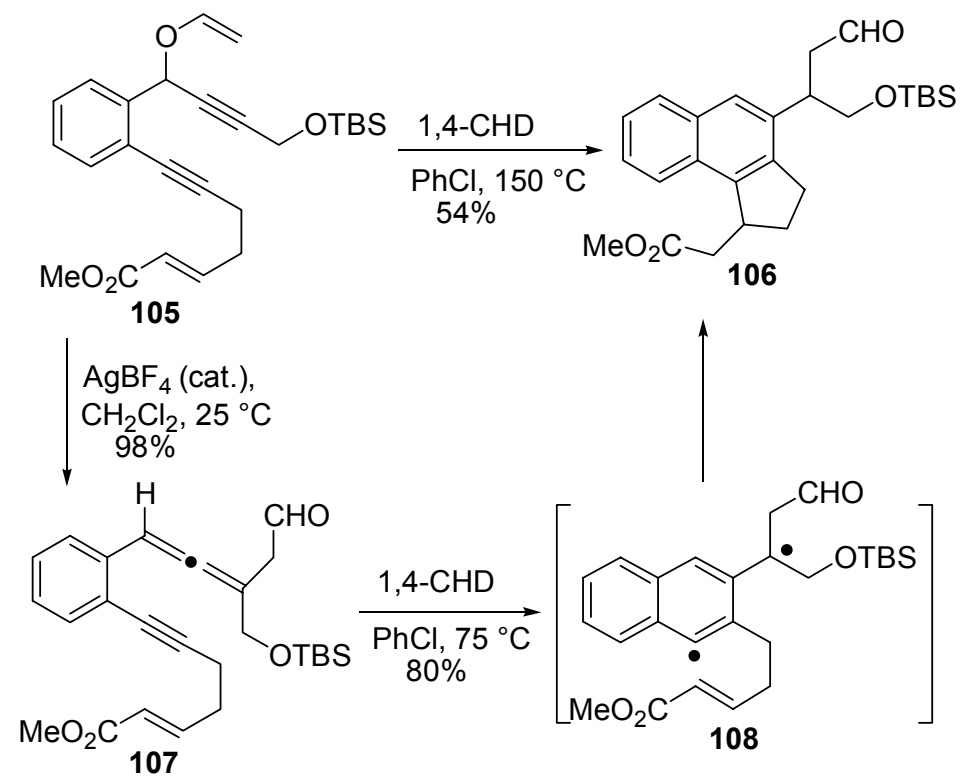

Scheme 24. Grissom's Approach to Benzannulated enyne-allenes.

Enyne-allenes could also be synthesized via base-catalyzed isomerization of enediyne sulfones. ${ }^{46}$ An example is outlined in Scheme $25{ }^{46 c}$ When enediyne sulfone $\mathbf{1 0 9}$ was treated with triethylamine in benzene and 1,4-cyclohexadiene at $37{ }^{\circ} \mathrm{C}$, the enyne-allene cyclization product 112 was isolated in $76 \%$ yield.

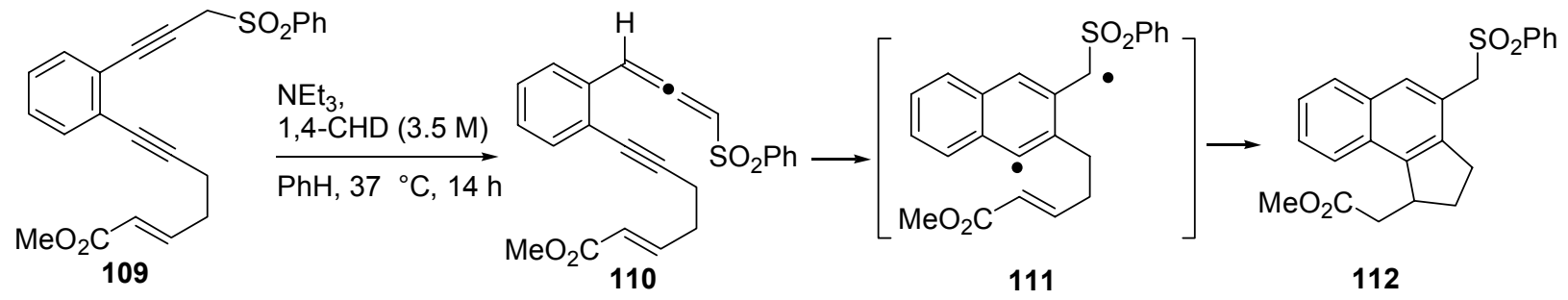

Scheme 25. Benzannulated enyne-allenes via base-catalyzed isomerization.

Dr. Finn's group developed a convenient methodology for the assembly of allene compounds from two aldehyde units and a doubly oxophilic "carbon atom" synthon. ${ }^{47}$ However, 
enyne-allenes were prepared in low to moderate yield by employing the doubly oxophilic ylide reagent prepared in situ from $\mathrm{TiCl}_{2}(\mathrm{OiPr})_{2},\left(\mathrm{Me}_{2} \mathrm{~N}\right)_{3} \mathrm{P}=\mathrm{CH}_{2}$, and $\mathrm{NaN}\left(\mathrm{SiMe}_{3}\right)_{2}$ ( $\left.\mathrm{Scheme} 26\right)$.

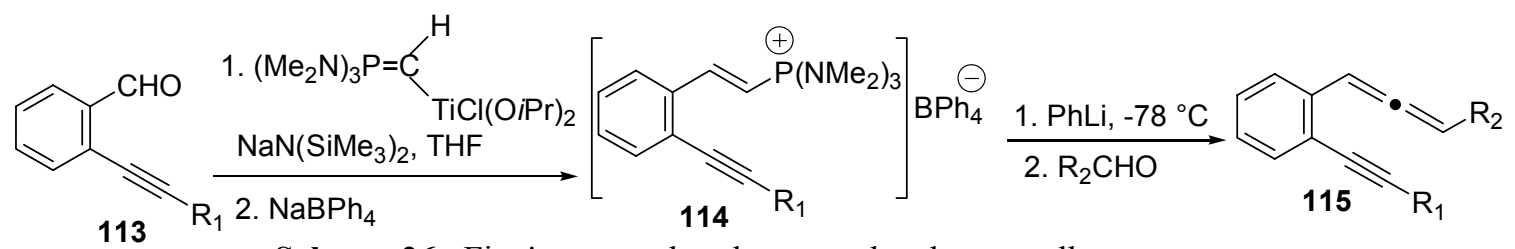

Scheme 26. Finn's approach to benzannulated enyne-allenes.

Dr. Gillmann's group reported that the thermolabile enyne-allene esters could be prepared by a Pd-catalyzed cross-coupling reaction between arylzinc halides and 2-haloallene carboxylates in moderate yield. ${ }^{35 a, 48}$ This is a mild reaction process to generate enyne-allenes. The specific examples are outlined in Scheme 27.

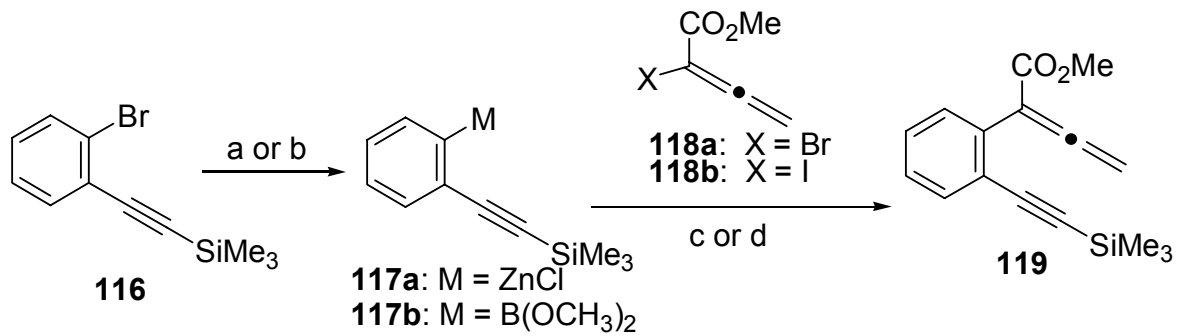

(a) $n$-BuLi, THF, $-90{ }^{\circ} \mathrm{C}, 10 \mathrm{~min}$; $\mathrm{ZnCl}_{2},-90{ }^{\circ} \mathrm{C}$ to $-20{ }^{\circ} \mathrm{C}$; (b) $n$-BuLi, THF, $-90{ }^{\circ} \mathrm{C}, 10 \mathrm{~min}$; $\mathrm{B}\left(\mathrm{OCH}_{3}\right)_{3}$ (1.3 equiv.), -90 to $0{ }^{\circ} \mathrm{C}$; (c) Coupling of 117a: $\mathrm{Pd}\left(\mathrm{PPh}_{3}\right)_{4}(5 \mathrm{~mol} \%)$ or $\mathrm{Pd}_{2}(\mathrm{dba})_{3} \cdot \mathrm{CHCl}_{3}(5 \mathrm{~mol} \%), \mathrm{AsPh}_{3}(40 \mathrm{~mol} \%), 118 \mathrm{a}$ or $118 \mathrm{~b}, \mathrm{THF}, \mathrm{rt}$;

(d) coupling of $117 \mathrm{~b}: \mathrm{Pd}_{2}(\mathrm{dba})_{3} \cdot \mathrm{CHCl}_{3}(5 \mathrm{~mol} \%), \mathrm{AsPh}_{3}(40 \mathrm{~mol} \%), 1 \mathrm{M}$ aq. $\mathrm{Ag}_{2} \mathrm{O}$ (4 equiv.), $118 \mathrm{~b}, \mathrm{THF}, 0^{\circ} \mathrm{C}$ to $\mathrm{rt}, 2 \mathrm{~h}$

Scheme 27. Gillmann's approach to benzannulated enyne-allenes.

Dr. Cunico's group developed a method for in situ formation of an enyne-allene based on their earlier findings of a facile elimination-trimethylsilyl (TMS) group migration within the propargylic framework of structures similar to $121 .^{49}$ The reaction sequences are outlined in Scheme 28 with all steps giving good yields.

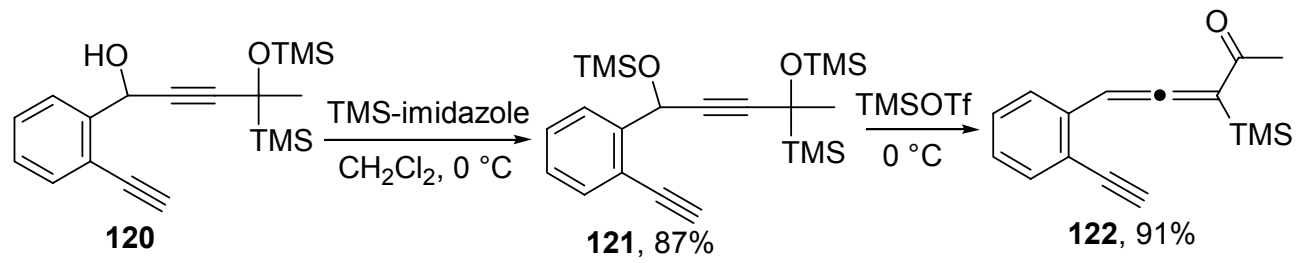

Scheme 28. Cunico's approach to benzannulated enyne-allenes. 
Dr. Schmittel's group developed a method for substituted enyne-allenes by the process outlined in Scheme 29. ${ }^{29}$ The formation of enyne-allenes could be understood assuming a migration of the carbonyl group.
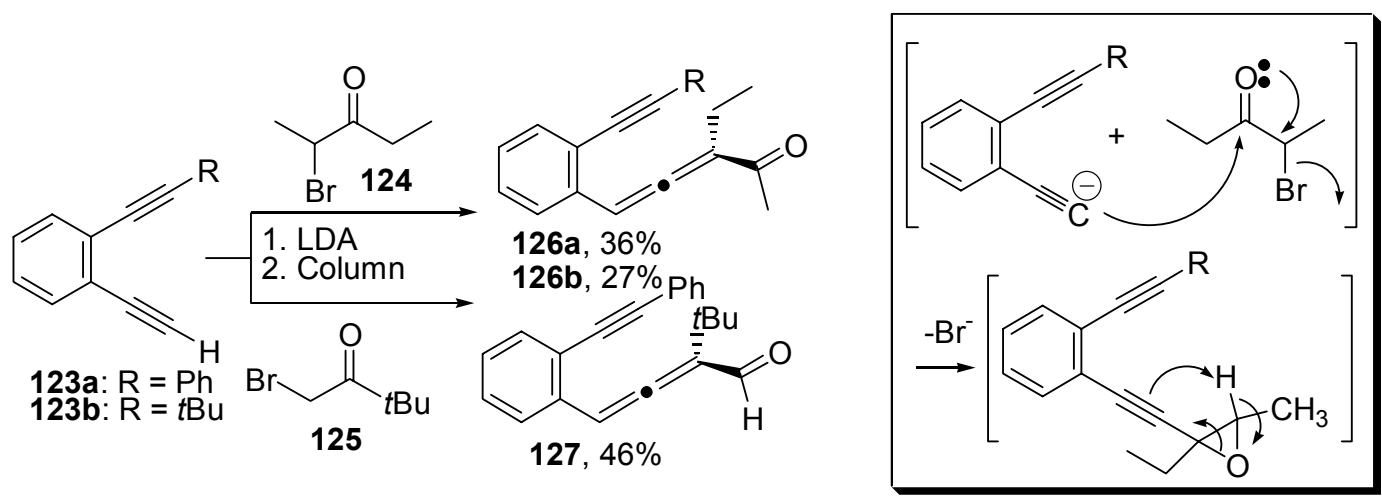

Scheme 29. Schmittel's approach to benzannulated enyne-allenes.

Dr. Schmittel's group also developed the preparation of enyne-allenes via the Pdcatalyzed addition of arylzinc chloride and cuprate addition to propargylic acetates (Scheme $30) .^{29 g}$

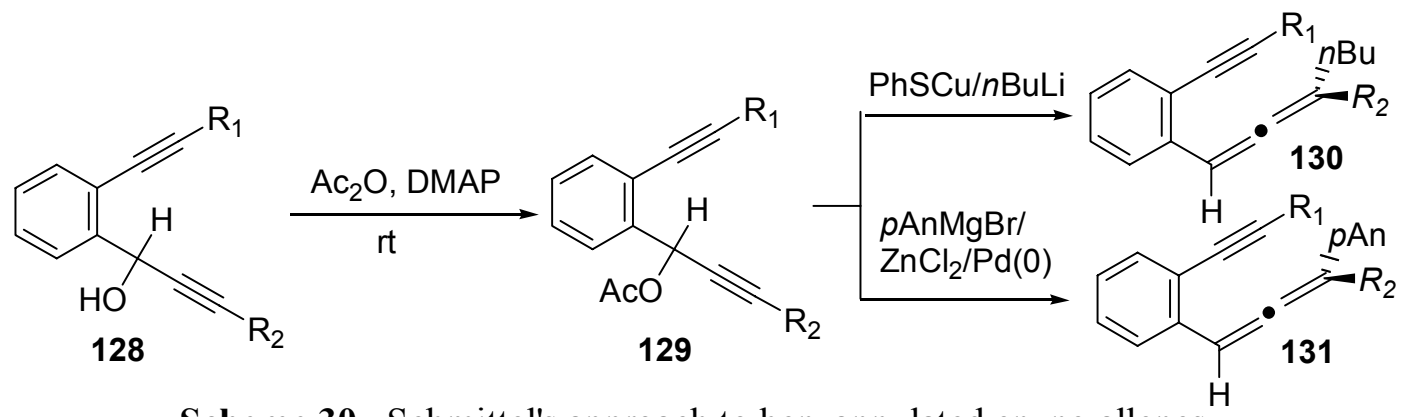

Scheme 30. Schmittel's approach to benzannulated enyne-allenes.

Our group developed several convenient procedures for the synthesis of enyne-allenes. ${ }^{50}$ One method involves bromoboration of 1-alkynes with $\mathrm{BBr}_{3}$ producing alkenyl boronic esters, followed by subsequent $\operatorname{Pd}(0)$-catalyzed cross-coupling with acetylenic zinc chlorides and iodination and a second $\operatorname{Pd}(0)$-catalyzed reaction with allenic zinc chlorides (Scheme 31$).{ }^{50 a}$ 


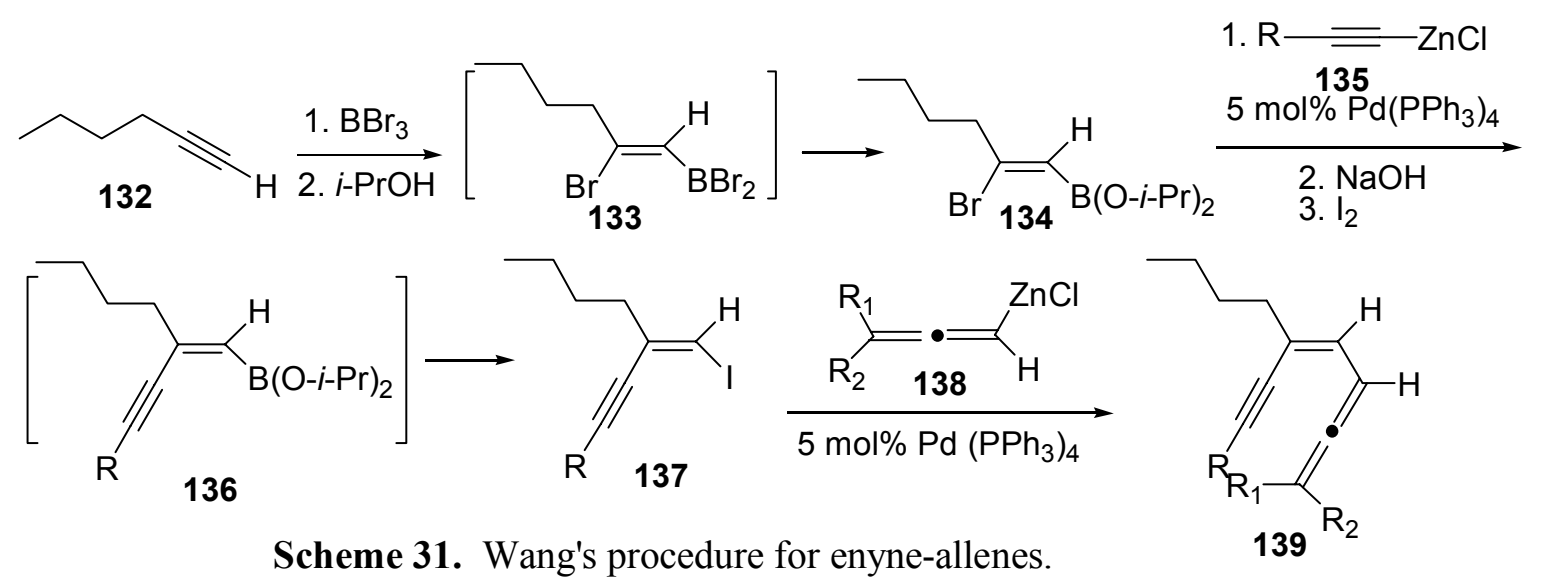

Dr. Lipton's group reported that the oxygen-substituted enyne-allenes could be prepared by treating the acetylenic ketones with cuprates and trapping the resultant enolates with acetic anhydride in good yield (Scheme 32). ${ }^{36}$

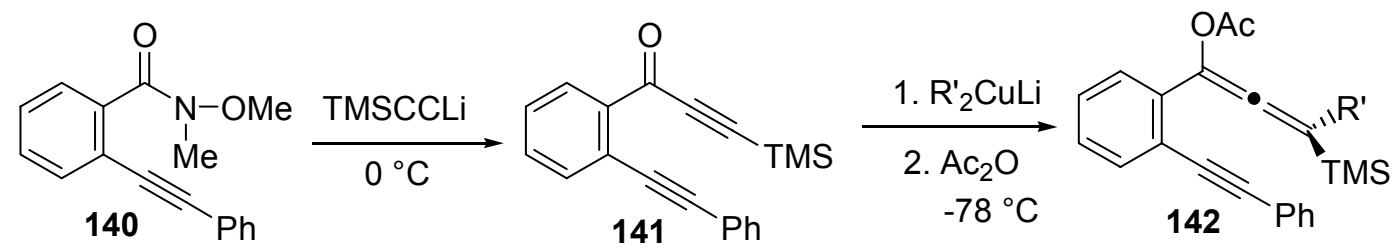

Scheme 32. Lipton's approach to benzannulated enyne-allenes.

Inanaga et al. reported that the allenes $\mathbf{1 4 7}$ could be produced from propargylic acetates by treatment of 143 with a catalytic amount of $\mathrm{Pd}\left(\mathrm{PPh}_{3}\right)_{4}$, 2-propanol, and $\mathrm{SmI}_{2}-\mathrm{THF}$. The reaction sequence with its mechanism is outlined in Scheme $33 .^{51}$

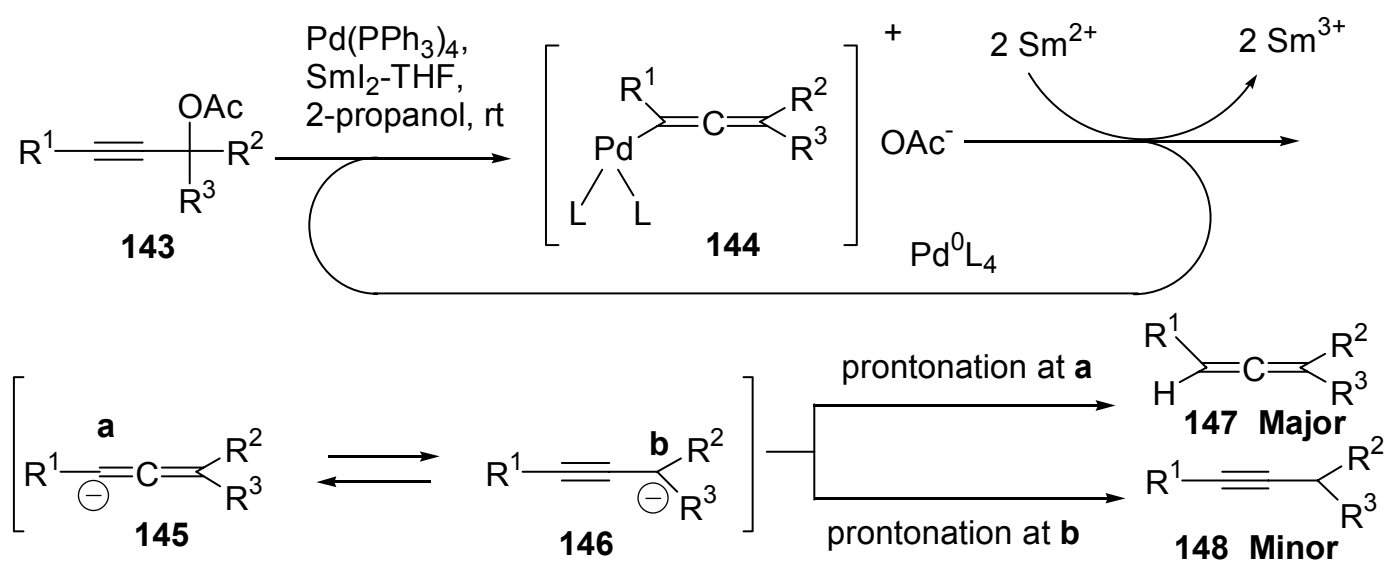

Scheme 33. Inanaga's approach to allenes. 


\section{CHAPTER II}

\section{Cascade Radical Cyclizations of Benzannulated Enyne-Allenes. Unusual Cleavage of a Benzene Ring Leading to Twisted 1,1'-Dialkyl-9,9'-bifluorenylidenes and Spiro[1H-cyclobut[a]indene-1,9'-[9H]fluorenes].}

\section{Introduction}

Our research group recently reported the use of thionyl chloride to induce an $\mathrm{S}_{\mathrm{N}} \mathrm{i}^{1}$ reaction of the benzannulated enediynyl propargylic alcohol 149, derived from condensation between 9fluorenone and the lithium acetylide $\mathbf{6 0}$ (Scheme 34$).{ }^{32 \mathrm{~b}}$ This scheme provided a convenient pathway to produce in situ the benzannulated enyne-allene 151. A subsequent $C^{2}-C^{6}$ cyclization reaction (Schmittel cyclization) then generated the biradical 152, which in turn underwent an intramolecular radical-radical coupling to give the formal Diels-Alder adduct 153. Tautomerization followed by hydrolysis then afforded 155 in $74 \%$ yield. Although the transformation from 151 to 153 could also be regarded as a concerted Diels-Alder reaction, the mechanistic, ${ }^{12,29 a, c, 31}$ theoretical, ${ }^{30 \mathrm{a}-\mathrm{f}}$ and DNA-cleaving ${ }^{29 \mathrm{~g}}$ studies suggest a two-step biradical pathway. Interestingly, in addition to $\mathbf{1 5 5}$, a minor amount of the $[2+2]$ cycloaddition adduct $156(12 \%)$ as a derivative of spiro[1H-cyclobut[a]indene-1,9'-[9H]fluorene] was also isolated. This synthetic strategy was adopted for the synthesis of a $\mathrm{C}_{44} \mathrm{H}_{26}$ hydrocarbon 69 having a carbon framework represented on the surface of $\mathrm{C}_{60} \cdot{ }^{32 \mathrm{a}}$ Furthermore, by employing a system containing two units of the benzannulated enyne-allene moiety, three highly twisted 4,5diarylphenanthrenes $\mathbf{7 8 a}-\mathbf{c}$ were obtained. ${ }^{33}$ 

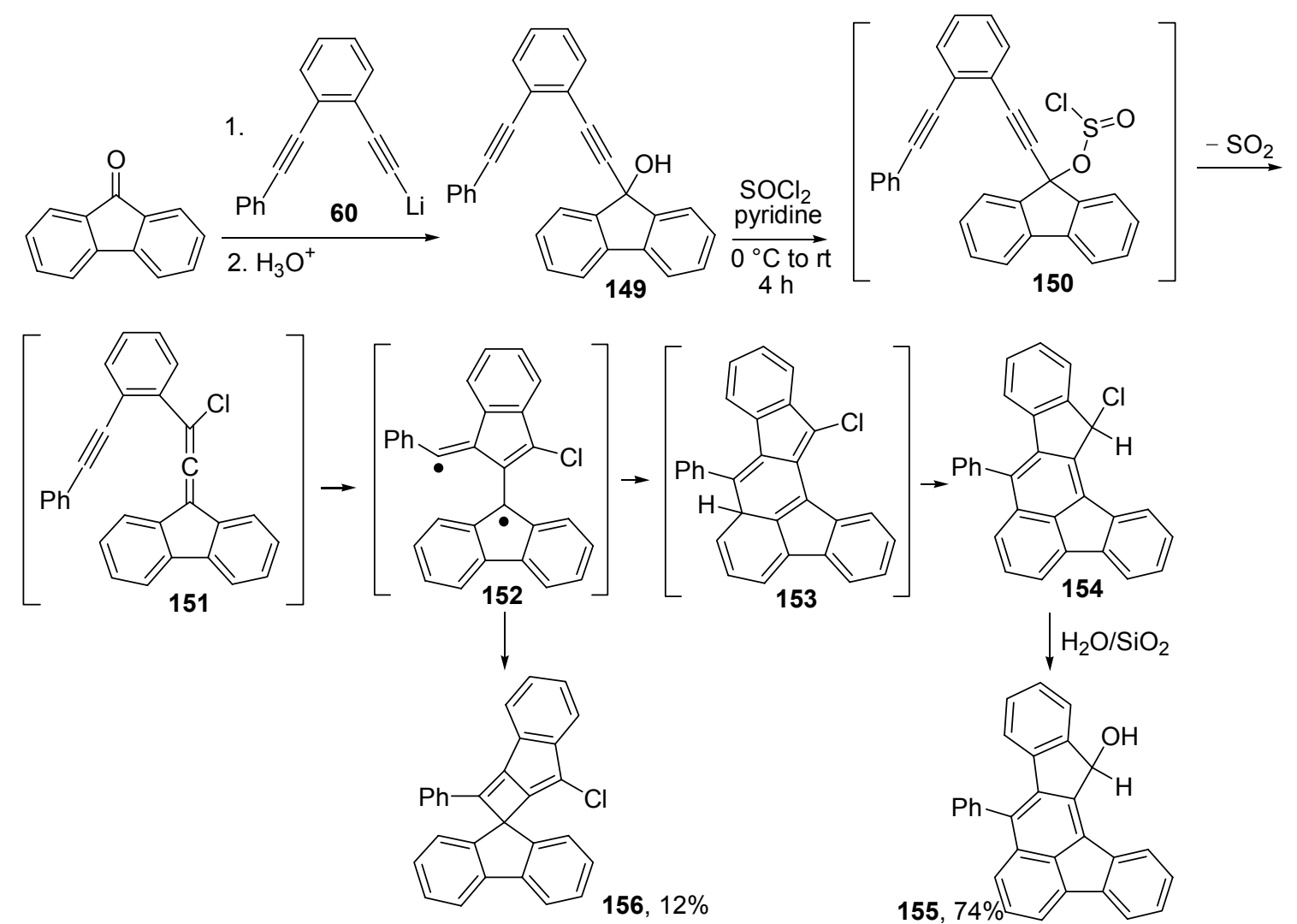

Scheme 34. Polycyclic compounds via a $C^{2}-C^{6}$ cyclization and subsequent reactions.

\section{Research Objective}

Based on our previous discovery about the formation of chlorinated benzannulated enyne-allenes via a $\mathrm{S}_{\mathrm{N}} \mathrm{i}^{1}$ reaction promoted by thionyl chloride and subsequent $\mathrm{C}^{2}-\mathrm{C}^{6}$ cyclization, ${ }^{32}$ we were interested in further exploring the use of molecules having two benzannulated enyne-allene units for the synthesis of polycyclic aromatic compounds. We envisioned the use of the following molecules to achieve this objective (Scheme 35). If these reactions follow the normal cyclization pathway, $\mathbf{1 5 8}$ could be produced. However, it was quite unexpected that this strategy led to the formation of highly twisted 1,1'-dialkyl-9,9'-bifluorenylidenes and other polycyclic compounds. Moreover, we were also interested in using the synthetic pathway developed for benzannulated enyne-allenes without a chloro substituent ${ }^{32 b, 33}$ for the preparation of polycyclic aromatic compounds via usual cyclization pathway. 


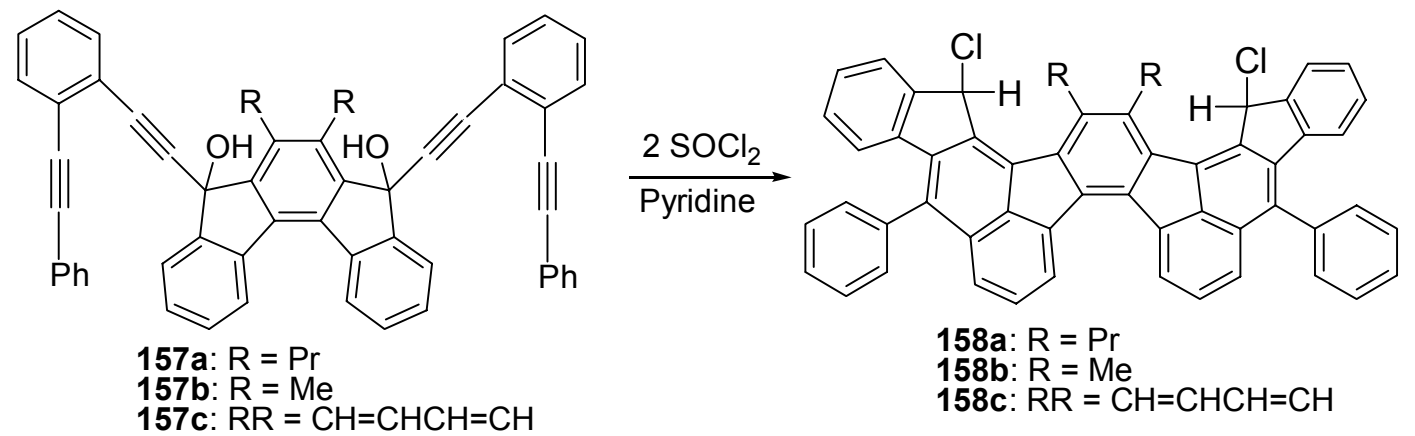

Scheme 35. Expected polycyclic compounds from diol 157.

\section{Literature Survey for the 9,9'-Bifluorenylidenes}

Because of overcrowding, the two fluorenylidene fragments of 9,9'-bifluorenylidenes are severely twisted. ${ }^{52}$ The crystal structure of the parent compound 159a shows a twist angle of ca. $42^{\circ}$ while the more crowded 1,1'-disubstituted 9,9'-bifluorenylidene 159b exhibits a higher twist angle of ca. $52^{\circ} .{ }^{52 a}$ Remarkable twist angles of $55^{\circ}$ and $66^{\circ}$ were recently reported for the octachlorobifluorenylidene 160 and the perchlorobifluorenylidene 161, respectively (Figure 4). ${ }^{52 \mathrm{~b}}$ The reported synthetic methods for 9,9'-bifluorenylidenes generally involve coupling of two fluorenyl fragments. ${ }^{52}$

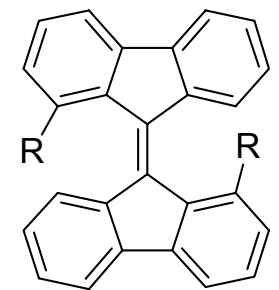

159a: $\mathrm{R}=\mathrm{H}, 42^{\circ}$ 159b: $\mathrm{R}=\mathrm{CO}_{2}-\mathrm{i}-\mathrm{Pr}, 52^{\circ}$<smiles>Clc1cc(Cl)c2c(c1)-c1cc(Cl)cc(Cl)c1C2=C1c2c(Cl)cc(Cl)cc2-c2cc(Cl)cc(Cl)c21</smiles>

$160,55^{\circ}$<smiles>Clc1c(Cl)c(Cl)c2c(c1Cl)C(=C1c3c(Cl)c(Cl)c(Cl)c(Cl)c3-c3c(Cl)c(Cl)c(Cl)c(Cl)c31)c1c(Cl)c(Cl)c(Cl)c(Cl)c1-2</smiles>

$161,66^{\circ}$

Figure 4. Some examples of twisted 9,9'-bifluorenylidenes.

\section{Results and Discussion}

\subsection{Unusual Cascade Cyclizations of Dipropyl Substituted Propargylic Diol}

The diketone 164 was synthesized by treatment of $1 \mathbf{1 6 2}^{53}$ with 4-octyne to form $\mathbf{1 6 3}$ followed by two intramolecular acylation reactions (Scheme 36). Condensation between 164 
and 2 equiv of 60 then provided the benzannulated enediynyl propargylic alcohol 157a as a mixture of the trans and cis isomers (isomer ratio $=2: 1$ ). Upon treatment with thionyl chloride, four products, including the 1,1'-dipropyl-9,9'-bifluorenylidene $\mathbf{1 6 5}$, the polycyclic compounds 166 and 167 , and the spiro[1H-cyclobut $[a]$ indene-1,9'-[9H]fluorene] 168 as a mixture of the trans and cis isomers (trans:cis $=5: 1$ ), were isolated. The structures of $\mathbf{1 6 5}, \mathbf{1 6 7}$, and the trans isomer of $\mathbf{1 6 8}$ were established by X-ray structure analysis.

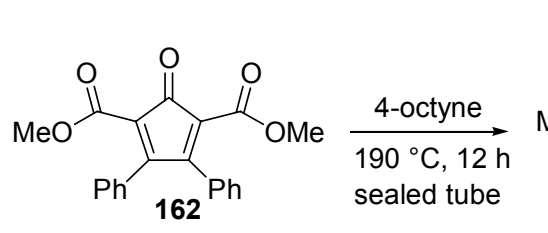

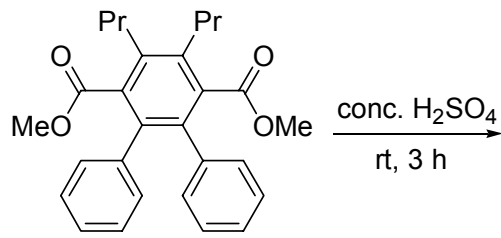

$163,50 \%$

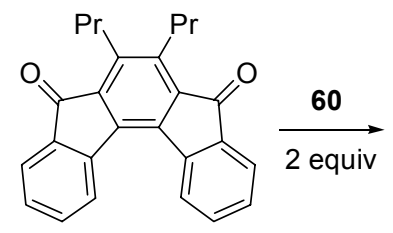

$164,79 \%$

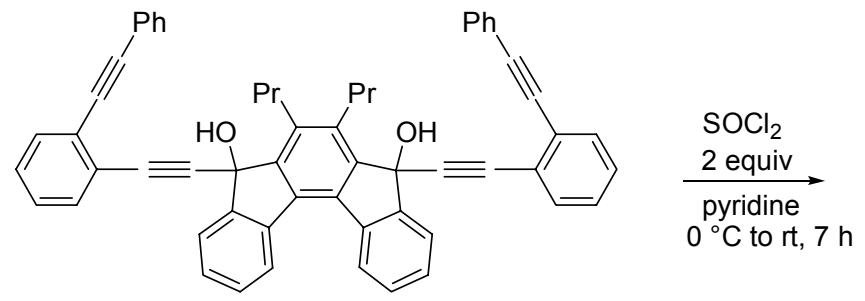

$157 \mathbf{a}, 94 \%$ (isomer ratio $=2: 1$ )

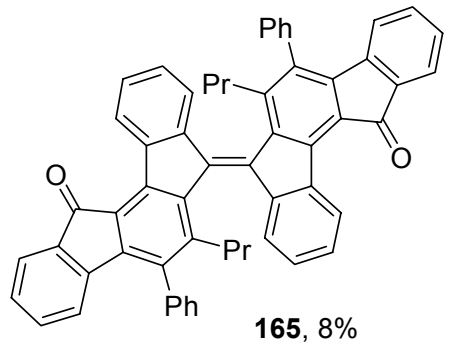

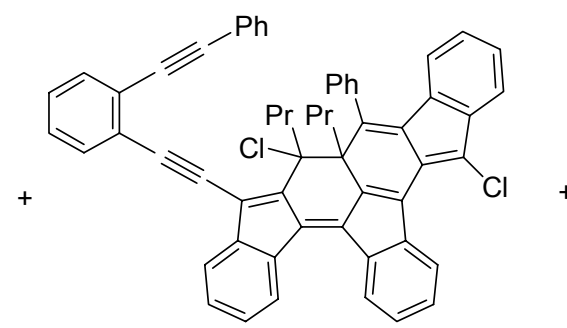

166, $3 \%$

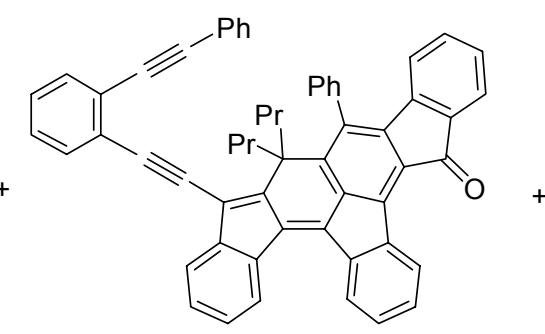

$167,28 \%$

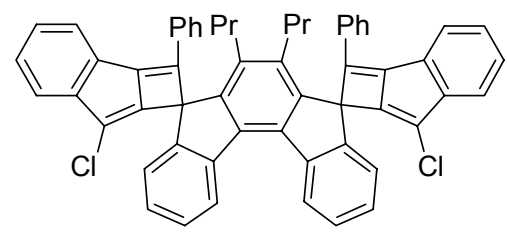

168, $30 \%$ (trans:cis $=5: 1$ )

Scheme 36. Unusual cascade cyclizations of 157 a leading to 165 and other polycyclic compounds.

The formation of the products $165, \mathbf{1 6 6}$, and 167 was unexpected. Apparently in the case of $\mathbf{1 6 5}$, the intramolecular radical-radical coupling of the initially formed biradical $\mathbf{1 7 0}$ involved the central benzene ring having the two propyl substituents to form 171 (Scheme 37). It was originally anticipated that such a coupling would occur on one of the peripheral benzene rings, which is sterically less crowded. However, molecular modeling suggests that this pathway suffers from nonbonded steric interactions between the chloro substituent and the neighboring 
propyl group on the central benzene ring. The effect of such a steric interaction in dictating the course of the reaction was observed previously. ${ }^{32 \mathrm{~b}}$ A second formal intramolecular Diels-Alder reaction, again promoted by thionyl chloride, then led to $\mathbf{1 7 2}$. Cleavage of the bond connecting the two carbons having the propyl substituent then gave the valence tautomer 173a, which could also be regarded as a resonance structure of $\mathbf{1 7 3 b}$ having a carbon-carbon single bond joining the two central five-membered rings. Rotation of the carbon-carbon bond joining the two central five-membered rings then gave the trans isomer 174. The temperature-dependent NMR studies have also shown that the rotational barriers of the cis-trans isomerization of several sterically congested 1,1'-disubstituted 9,9'-bifluorenylidenes are relatively low, allowing rapid interconversion to occur at ambient temperature. ${ }^{54}$ Oxidation of $\mathbf{1 7 4}$, presumably by oxygen, followed by hydrolysis then produced $\mathbf{1 6 5}$. The X-ray crystal structure reveals that it has a twist angle of $45.2^{\circ}$ for the carbon-carbon double bond connecting the two bifluorenylidene fragments (Figure 5a,b). This carbon-carbon double bond has a bond length of $1.380 \AA$, unusually long for a carbon-carbon double bond indicating a partial diradical character for the bond.

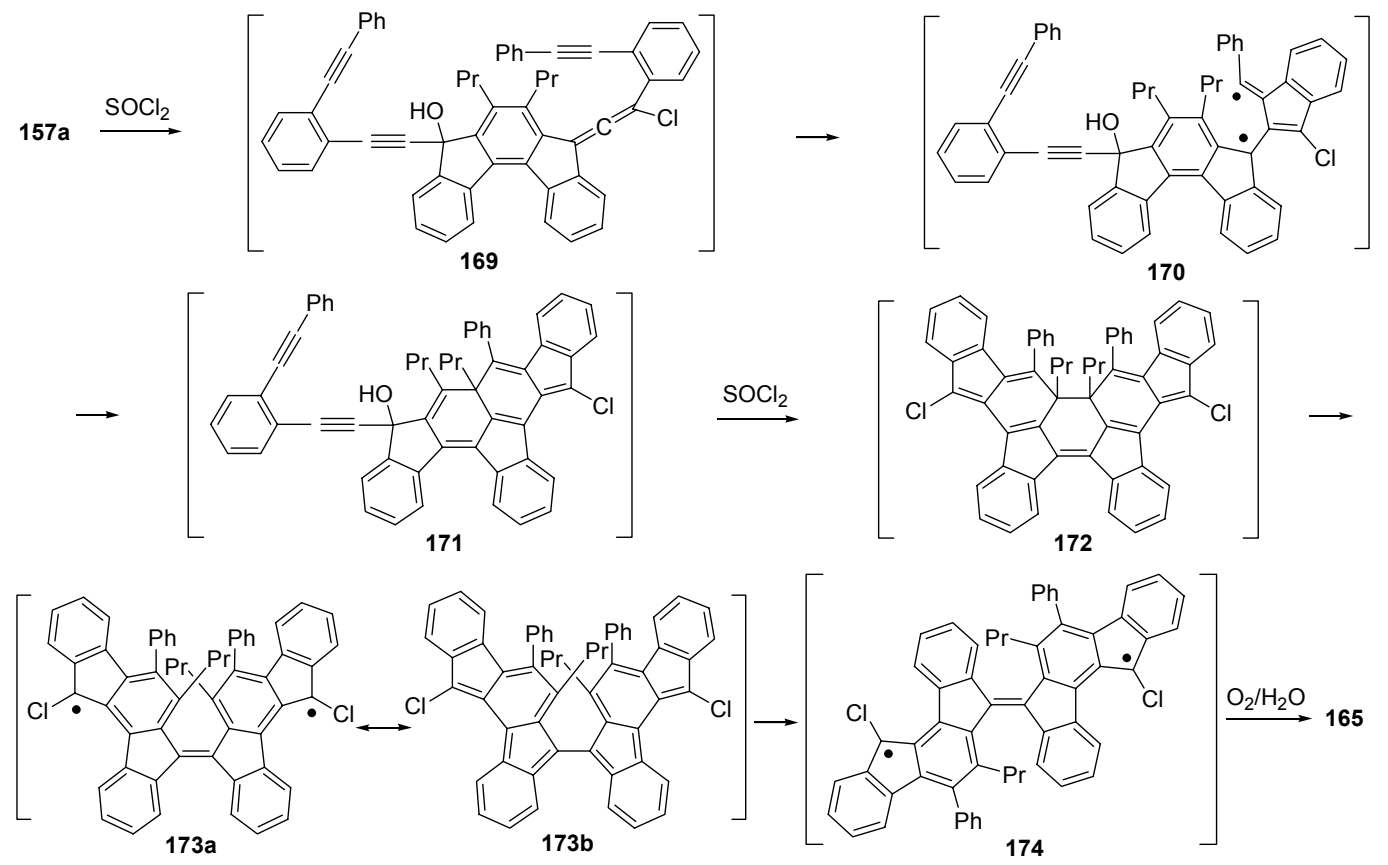

Scheme 37. Mechanism of unusual cyclization leading to $\mathbf{1 6 5}$. 
It is worth noting that transformation from $157 \mathbf{a}$ to 165 involves a rare occurrence of cleavage of a benzene ring. However, the loss of the resonance energy is more than compensated for with the eventual formation of two new benzene rings in $\mathbf{1 6 5}$.

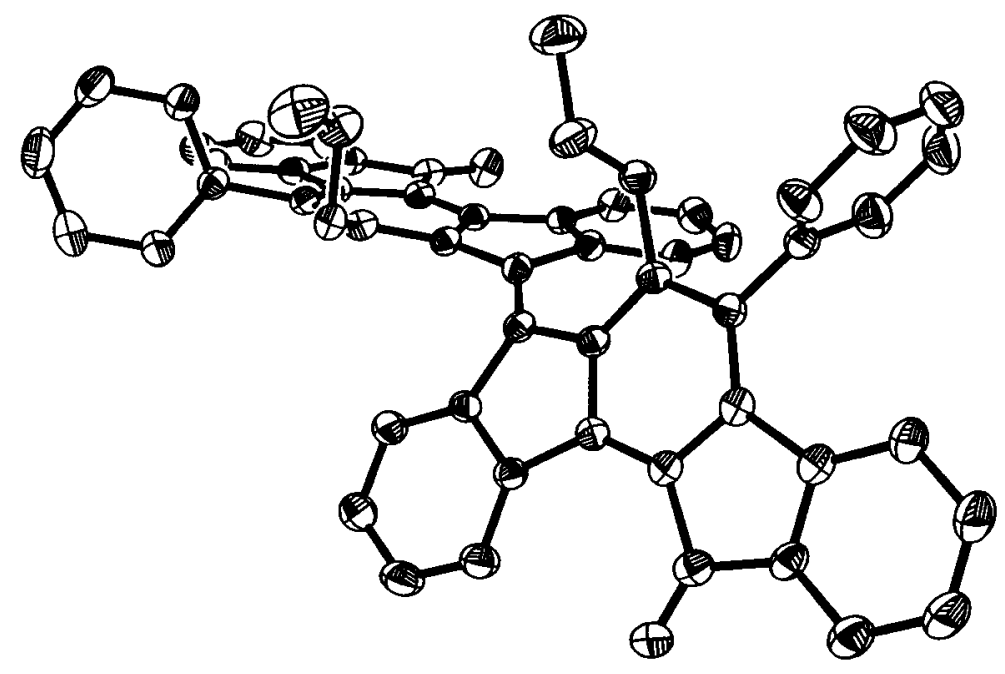

Figure 5a. ORTEP drawing of the crystal structure of the 1,1'-dipropyl9,9'-bifluorenylidene $\mathbf{1 6 5}$ with hydrogen atoms omitted for clarity.

The chlorosulfite 175, derived from 171, could also undergo a different $\mathrm{S}_{\mathrm{N}} \mathrm{i}^{1}$ reaction involving the carbon-carbon double bond substituted with a propyl group to produce the chloride 166 (Scheme 38). The structure of $\mathbf{1 6 6}$ was tentatively assigned on the basis of the MS and ${ }^{1} \mathrm{H}$ NMR spectra. It was observed by ${ }^{1} \mathrm{H}$ NMR that the majority of $\mathbf{1 6 6}$ in the crude reaction mixture was converted to $\mathbf{1 6 7}$ after purification by silica gel column chromatography. Presumably, a 1,2-migration of the propyl group to the adjacent carbon having a chloro substituent occurred to give 176, which upon hydrolysis then produced $\mathbf{1 6 7}$.

Two intramolecular $[2+2]$ cycloaddition reactions with the two chlorinated allenes derived from 157a could account for the formation of $\mathbf{1 6 8}$ as a mixture of the trans and cis isomers. A single crystal of the trans isomer suitable for X-ray structure analysis was obtained. 


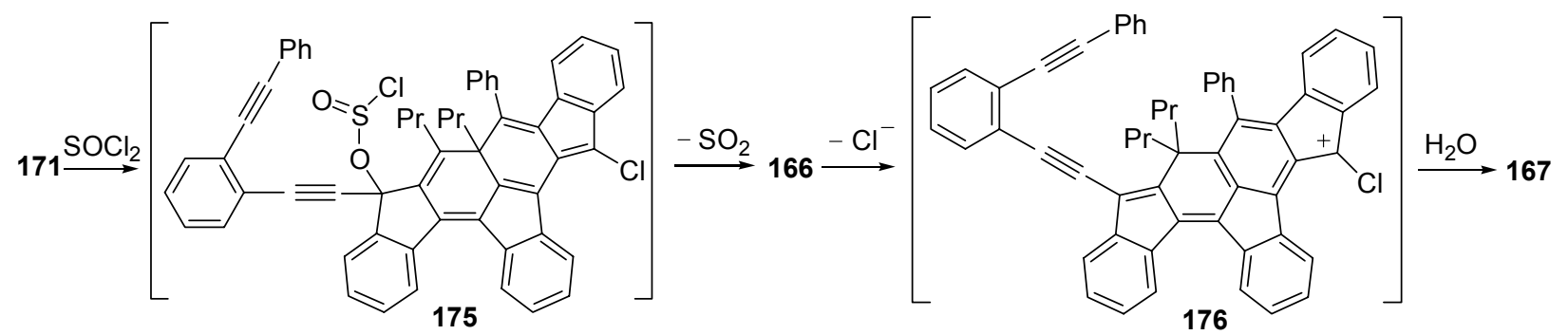

Scheme 38. Mechanism of unusual cyclization leading to $\mathbf{1 6 6}$ and $\mathbf{1 6 7 .}$

\subsection{Unusual Cascade Cyclizations of Dimethyl Substituted Propargylic Diol}

The diketone 179 was likewise synthesized by two intramolecular acylation reactions of 178, derived from condensation between 162 and 1,4-dichloro-2-butyne to form $\mathbf{1 7 7}$ followed by reduction with tributyltin hydride (Scheme 39). Treatment of $\mathbf{1 7 9}$ with two equiv of $\mathbf{6 0}$ then afforded the diol $\mathbf{1 5 7 b}$ also as a mixture of the trans and cis isomers (isomer ratio $=2: 1$ ). On exposure to thionyl chloride, $\mathbf{1 5 7 b}$ was also transformed to the 1,1'-dimethyl-9,9'-bifluorenylidene 180 and the polycyclic compounds 181 and 182. The structure of 181 was tentatively assigned on the basis of the MS and ${ }^{1} \mathrm{H}$ NMR spectra. Compared to the case of 157a, elimination of a molecule of hydrogen chloride from 181 to form 182 appears to occur more readily than 1,2-migration of the adjacent methyl group. The structure of $\mathbf{1 8 2}$ was established by X-ray structure analysis. The [2+2] cycloaddition adduct was not detected in this case.
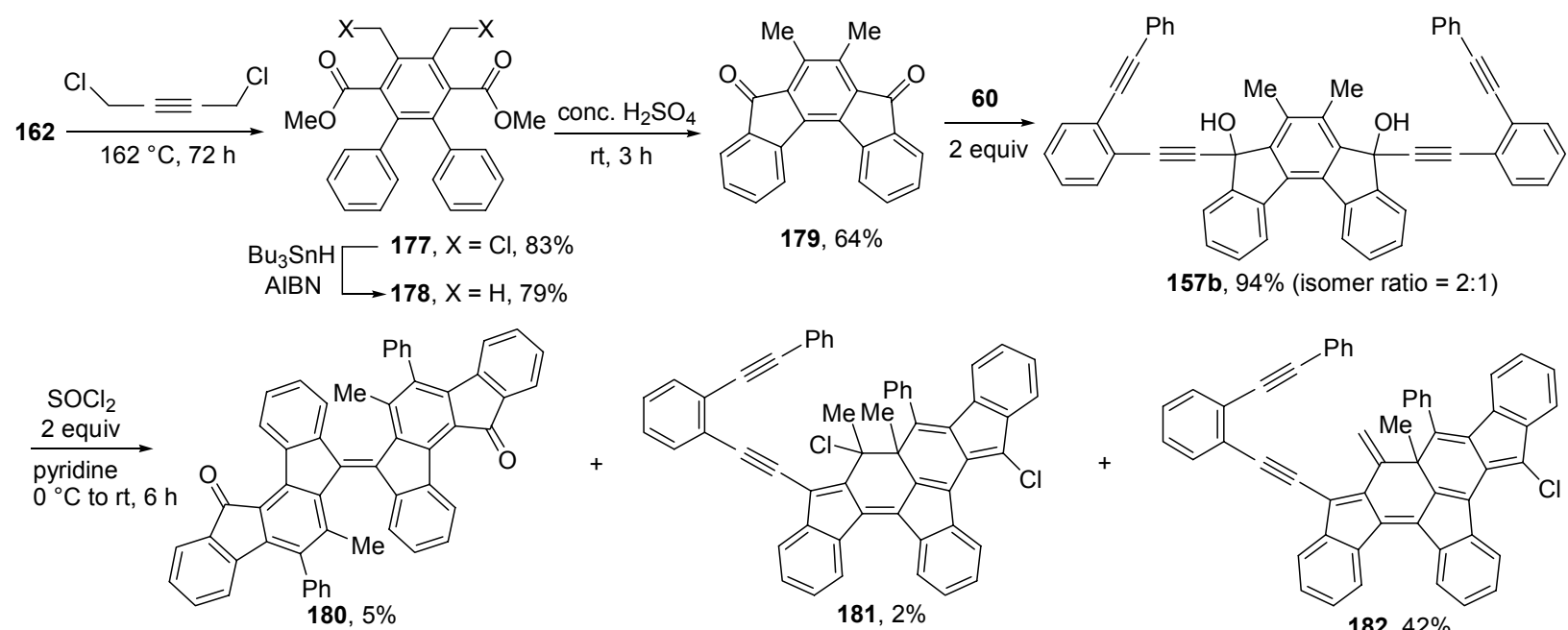

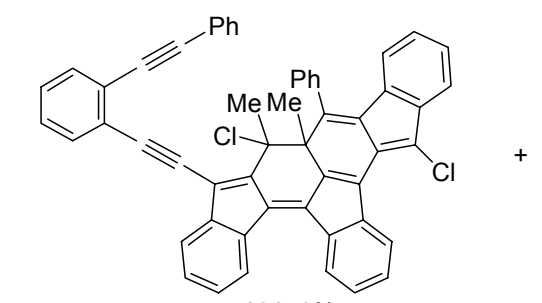

$181,2 \%$

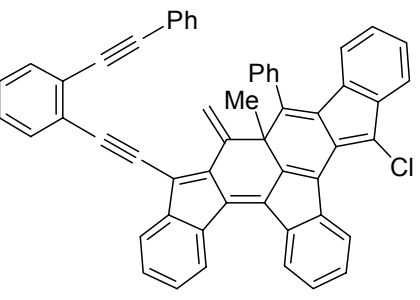

$182,42 \%$

Scheme 39. Unusual cascade cyclizations of $\mathbf{1 5 7 b}$ leading to $\mathbf{1 8 0}$ and other polycyclic compounds. 


\subsection{Cascade Cyclizations of Benzannulated Propargylic Diol}

Condensation between 162 and benzyne, ${ }^{55}$ generated in situ from anthranilic acid, eventually led to the diketone $\mathbf{1 8 4}$ and subsequently the diol 157c as a mixture of the trans and cis isomers (isomer ratio $=3: 1$ ) (Scheme 40). Treatment of $157 \mathbf{c}$ with 2 equiv of thionyl chloride produced the [2+2] cycloaddition adduct $\mathbf{1 8 5}$ as a mixture of the trans and cis isomers (trans:cis $=3: 1$ ). In addition, the alcohol $\mathbf{1 8 6}$ as a mixture of the trans and cis isomers (isomer ratio $=2: 1$ ) and the ketone 187 were also isolated. The structure of the trans isomer of $\mathbf{1 8 5}$ was established by X-ray structure analysis. Unlike the cases of $157 \mathbf{a}$ and $157 \mathbf{b}$, the formation of 186 and 187 indicated that the intramolecular radical-radical coupling reaction involved one of the peripheral benzene rings. Apparently, the central naphthyl ring with its higher resonance energy is more resistant to being attacked at the ring junction because such an attack would result in the loss of the entire naphthyl aromaticity. The reaction pathway leading to the alcohol $\mathbf{1 8 6}$ is similar to the one described for 155. It was previously observed that treatment of the chloride $\mathbf{1 5 4}$ and other analogous compounds with $\mathrm{NaOH}$ under air produced the corresponding ketones in excellent yields. ${ }^{56}$ A similar reaction could likewise give rise to the ketone $\mathbf{1 8 7 .}$

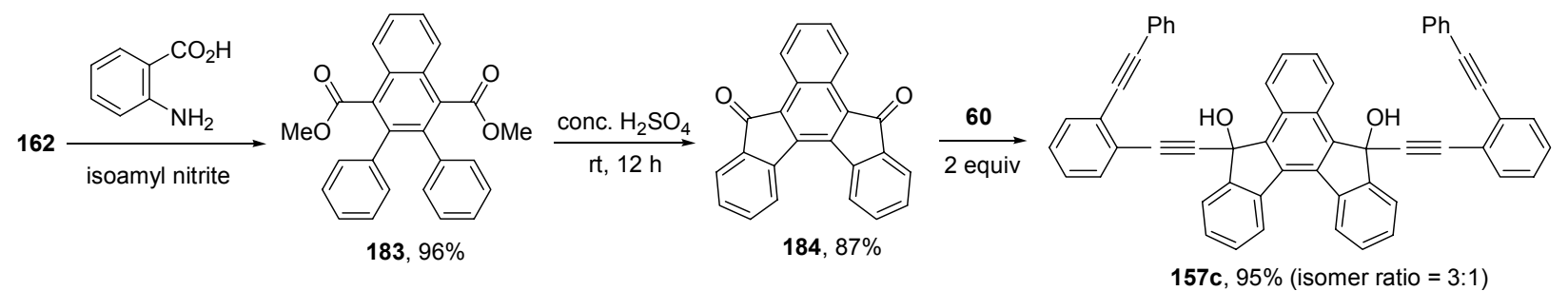

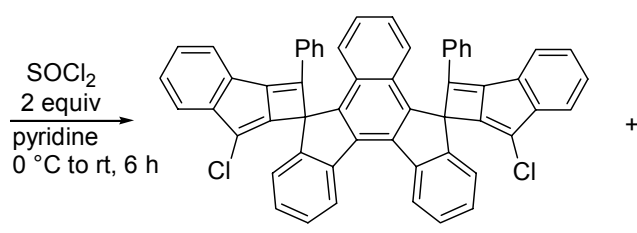

$185,26 \%$ (trans:cis = 3:1)

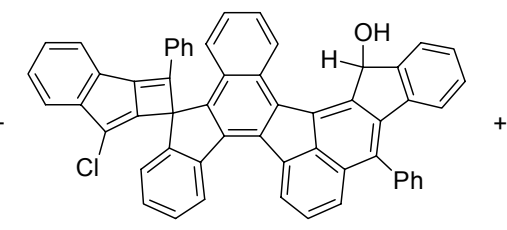

$186,14 \%$ (isomer ratio $=2: 1$ )

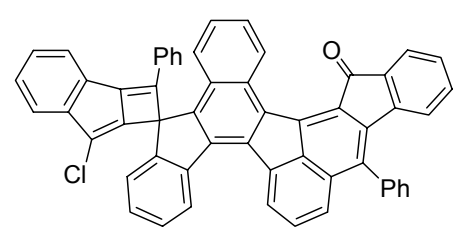

$187,1 \%$

Scheme 40. Cascade cyclizations of $157 \mathrm{c}$ leading to polycyclic compounds. 


\subsection{Other Attempts to Synthesize Polycyclic Aromatic Compounds}

Scheme 41 outlines attempts to synthesize polycyclic aromatic hydrocarbon 189 via cascade radical cyclization of the molecules having two units of benzannulated enyne-allenes without a chloro substituent. $^{32 \mathrm{~b}}$ Treatment of $\mathbf{1 5 7 b}$ with trifluoroacetic acid in the presence of triethylsilane at low temperature afforded the tetraacetylenic hydrocarbon $\mathbf{1 8 8 b}$ as a 2:1 mixture of diastereomers. On exposure to potassium tert-butoxide under refluxing toluene at $110{ }^{\circ} \mathrm{C}$, the reaction mixture turned into dark pink color immediately. The ${ }^{1} \mathrm{H}$ NMR spectrum of the crude reaction mixture showed only broad peaks in the aromatic region, indicating that the starting material decomposed or polymerized. Treatment of $\mathbf{1 8 8 b}$ with weaker bases, such as basic aluminum oxide, triethylamine, basic aluminum oxide in the presence of $1,4-\mathrm{CHD}$, at $0{ }^{\circ} \mathrm{C}$ to room temperature gave similar results. However, treatment of $\mathbf{1 5 7 \mathbf { c }}$ with trifluoroacetic acid in the presence of triethylsilane at low temperature gave a dark-colored solid. The ${ }^{1} \mathrm{H}$ NMR spectrum of the crude reaction mixture showed only broad peaks in the aromatic region, indicating that the starting diol $157 \mathbf{c}$ decomposed or polymerized.

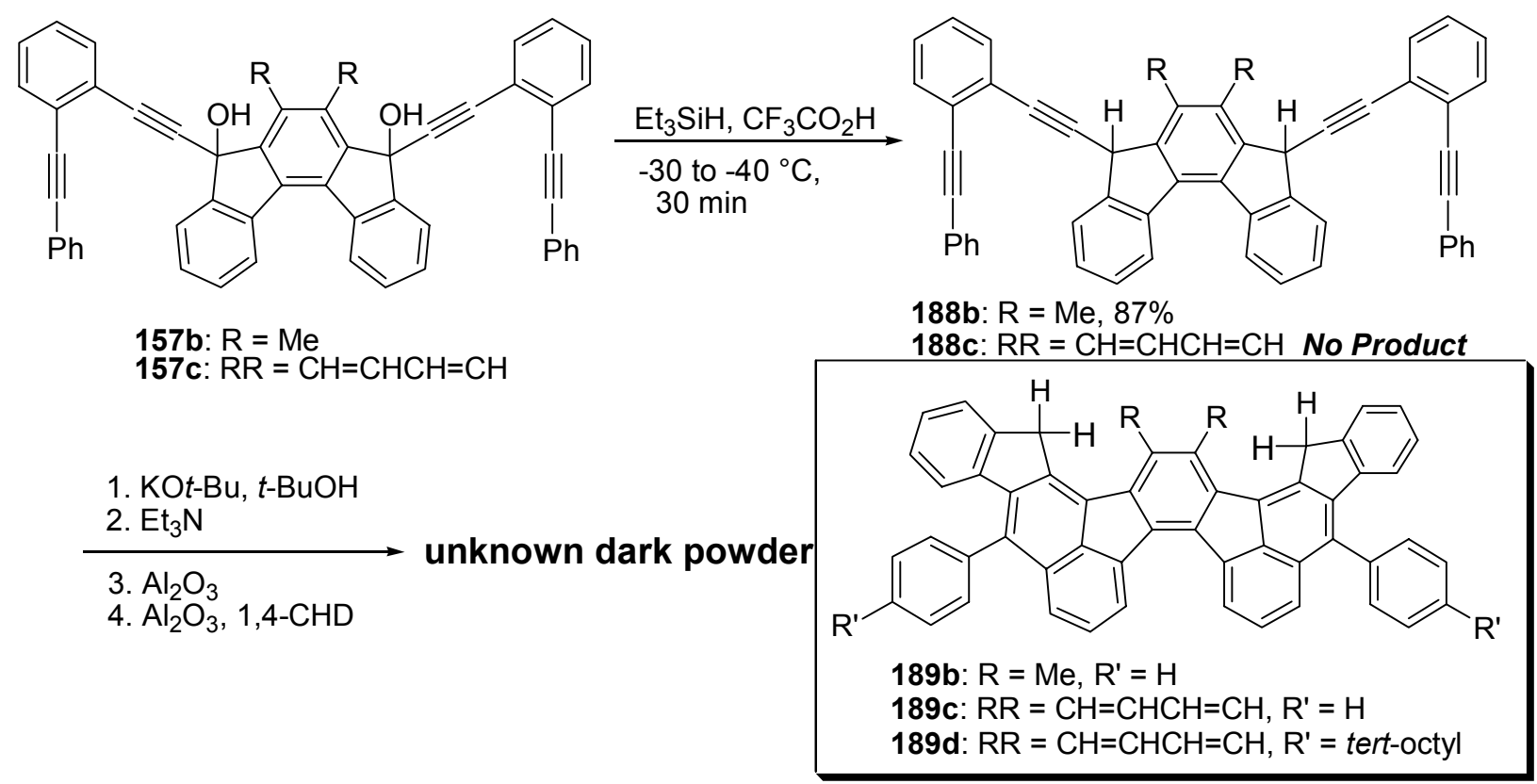

Scheme 41. Attempt to synthesize compound 189 via the new synthetic pathway. 
Scheme 42 outlines a study to generate enyne-allenes in situ from crude propargylic acetate promoted by $\mathrm{Pd}\left(\mathrm{PPh}_{3}\right)_{4}$, 2-propanol and $\mathrm{SmI}_{2}$-THF, followed by cascade radical cyclization leading to polycyclic hydrocarbons in a single operation. ${ }^{51}$ Condensation between 9fluorenone and the lithium acetylide $\mathbf{6 0}$ as reported previously furnished the corresponding alkoxide ${ }^{32 b}$ which was captured by acetic anhydride to afford the propargylic acetate 190. Upon treatment of the reaction mixture with $\mathrm{Pd}\left(\mathrm{PPh}_{3}\right)_{4}, \mathrm{SmI}_{2}$-THF, and 2-propanol, polycyclic hydrocarbon 191 was isolated. The structure was established by ${ }^{1} \mathrm{H}$ NMR and ${ }^{13} \mathrm{C}$ NMR.

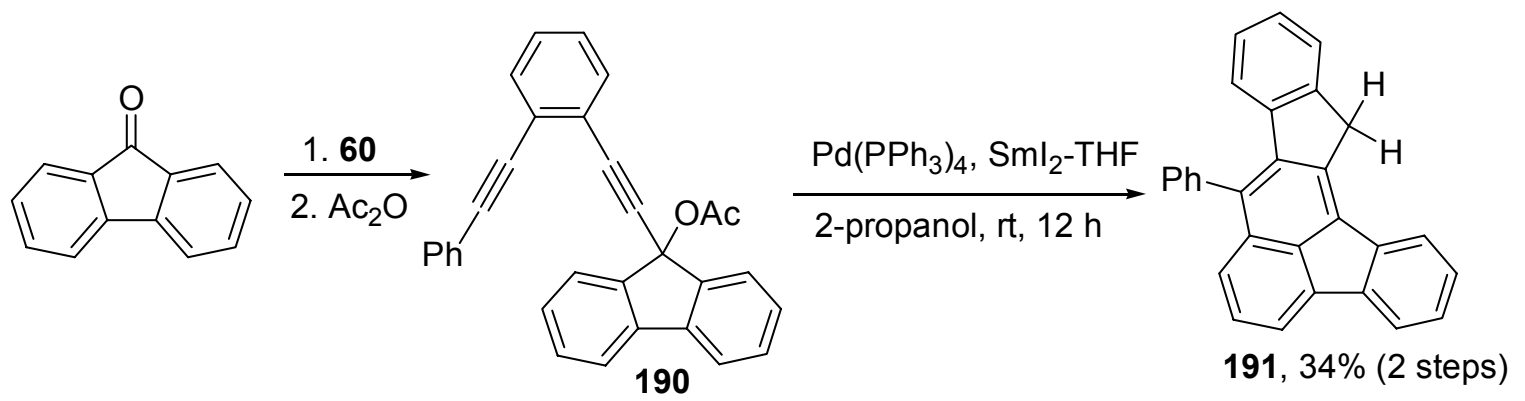

Scheme 42. Polycyclic hydrocarbon 191 from 190.

Scheme 43 outlines a similar reaction sequence starting from compound $\mathbf{1 8 4}$. Condensation between 184 and 2 equiv of 60 or its derivative 192 furnished the corresponding alkoxide, which was captured with acetic anhydride leading to propargylic acetate. Upon treatment of the reaction mixture of 193a with $\mathrm{Pd}\left(\mathrm{PPh}_{3}\right)_{4}, \mathrm{SmI}_{2}-\mathrm{THF}$, and 2-propanol, a black solid with low solubility in $\mathrm{CDCl}_{3}$ was obtained. The ${ }^{1} \mathrm{H}$ NMR spectrum of the crude reaction mixture showed only broad peaks in the aromatic region, indicating that the starting material decomposed or polymerized. To improve the solubility of final product, 200 as a precursor of 192 with a long aliphatic chain was synthesized (Scheme 44). ${ }^{57}$ A similar result of unidentifiable products was obtained by treatment of the reaction mixture of $193 \mathbf{b}$ with $\mathrm{Pd}\left(\mathrm{PPh}_{3}\right)_{4}, \mathrm{SmI}_{2}-\mathrm{THF}$, and 2-propanol. 


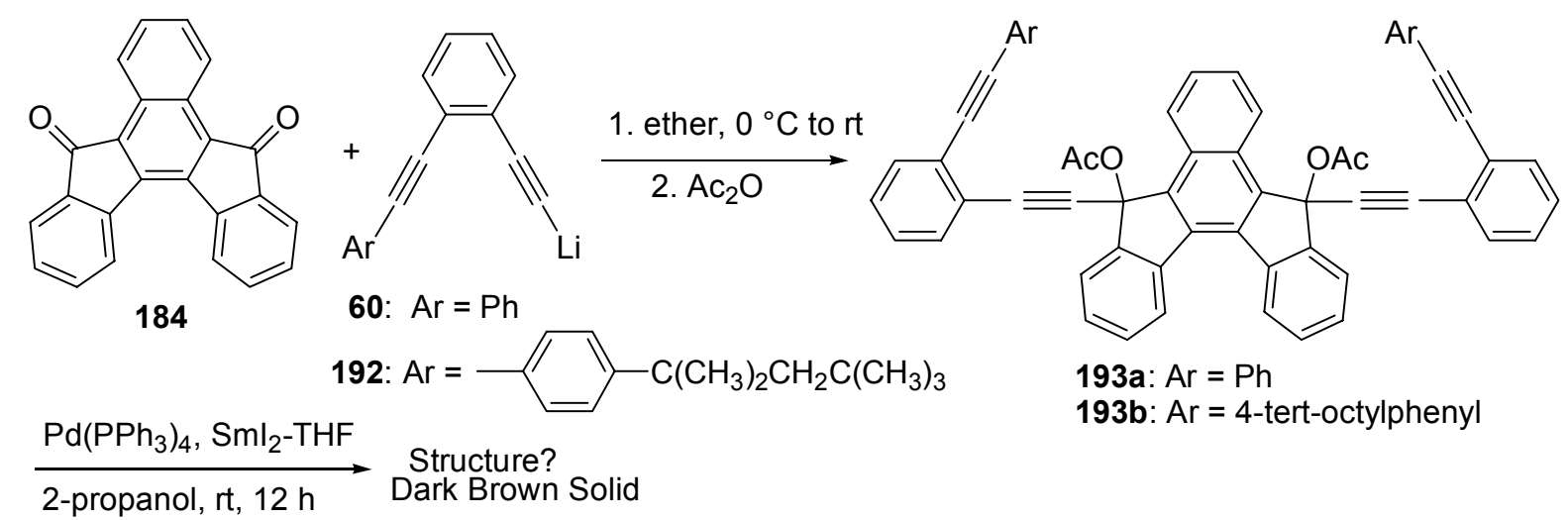

Scheme 43. Attempt to synthesize polycyclic compounds $189 \mathrm{c}$ and $\mathbf{1 8 9 d}$.

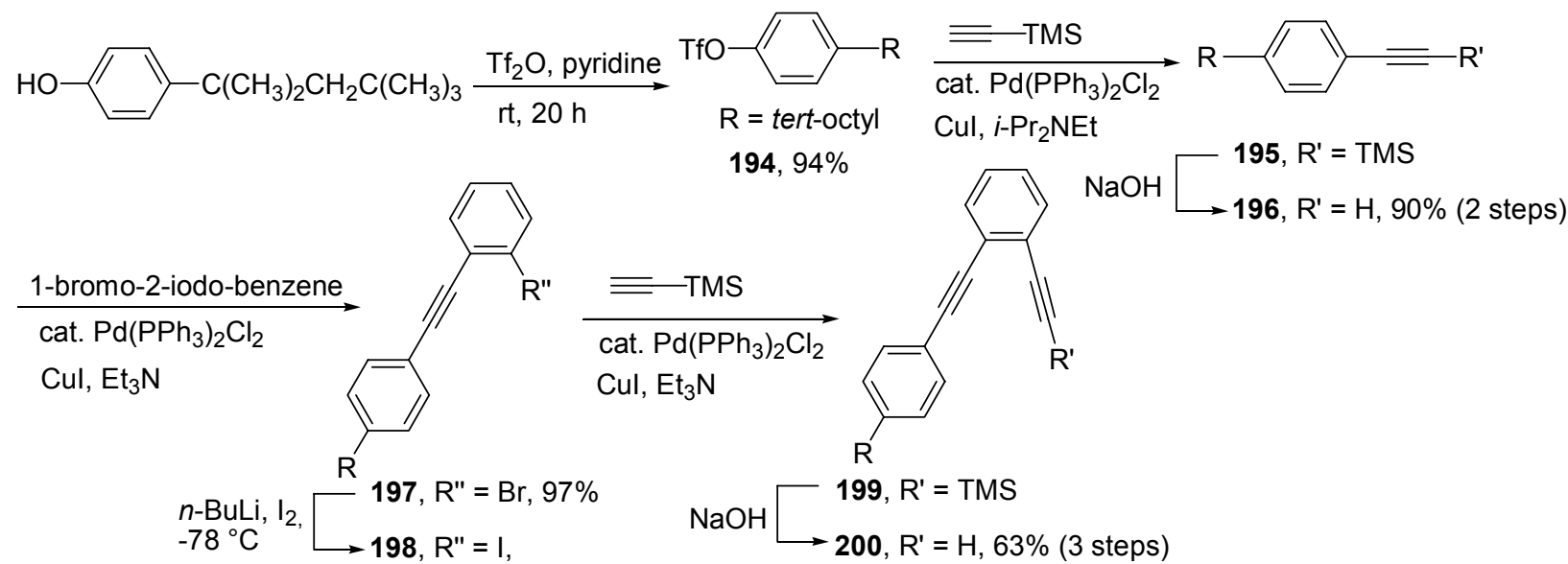

\section{Conclusions}

Scheme 44. Synthesis of 200 as a precursor of 192.

The transformations from $\mathbf{1 5 7 a}$ and $\mathbf{1 5 7 b}$ to the highly twisted 1,1'-dialkyl-9,9'bifluorenylidenes $\mathbf{1 6 5}$ and $\mathbf{1 8 0}$, respectively, represent a novel synthetic pathway to these highly twisted compounds. The cascade sequence involves an unusual cleavage of a benzene ring. Alternatively, the intramolecular $[2+2]$ cycloaddition reactions of the benzannulated enyne-allenes lead to the spiro[1H-cyclobut[a]indene-1,9'-[9H]fluorenes] $\mathbf{1 6 8}$ and 185-187. They are also structurally interesting compounds. Several approaches to prepare polycyclic aromatic compounds $158 \mathbf{a}-\mathbf{c}$ and $\mathbf{1 8 9} \mathbf{b}-\mathbf{d}$ via usual cascade radical cyclization of the molecules having two units of benzannulated enyne-allenes with or without a chloro substituent were explored. 


\section{CHAPTER III}

\section{Polycyclic Aromatic Compounds via Radical Cyclizations of Benzannulated Enyne-Allenes \\ Derived from Ireland-Claisen Rearrangement}

\section{Introduction}

Biradicals generated from cyclization of (Z)-1,2,4-heptatrien-6-ynes (enyne-allenes) and the benzannulated analogues under mild thermal conditions provide many opportunities for subsequent synthetic applications. ${ }^{9,11}$ Cyclization of the enyne-allene $\mathbf{2 0 1}$ could proceed either via the $C^{2}-C^{7}$ pathway (Myers-Saito cyclization) to form the $\alpha, 3$-didehydrotoluene/naphthalene biradical $\mathbf{2 0 2}^{27 a, b, 28}$ or via the $C^{2}-C^{6}$ pathway (Schmittel cyclization) to produce the fulvene/benzofulvene biradical 203 (Scheme 45). ${ }^{10,12,29 a, c, f, 40 b}$ The enyne-allenes bearing an aryl substituent or a sterically demanding group, such as the tert-butyl group or the trimethylsilyl group, at the alkynyl terminus favor the Schmittel cyclization pathway.

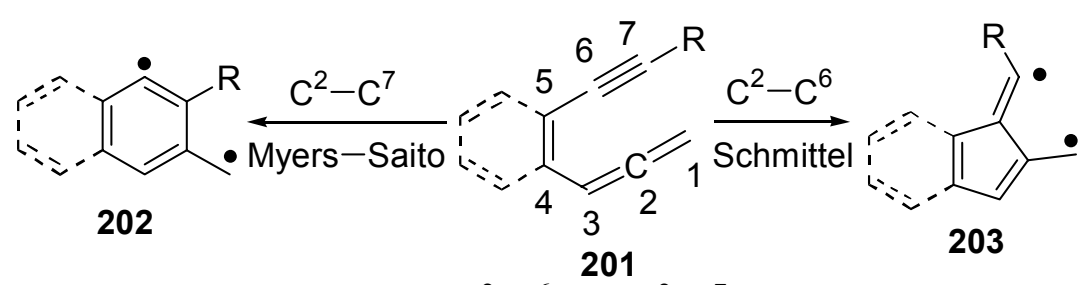

Scheme 45. $C^{2}-C^{6}$ and $C^{2}-C^{7}$ cyclizations.

One of the synthetic methods that have been used to prepare in situ the benzannulated enyne-allenes for the subsequent Myers-Saito cyclization reaction involves producing the allenic moiety via thermolysis of propargyl vinyl ethers to promote the [3,3] sigmatropic Claisen rearrangement at $150{ }^{\circ} \mathrm{C}$. ${ }^{4}$ The corresponding Lewis-acid catalyzed [3,3] sigmatropic Claisen rearrangement promoted by $\mathrm{AgBF}_{4}$ was also successfully adopted for the preparation of the benzannulated enyne-allenes at $25^{\circ} \mathrm{C} .{ }^{44}$

The silyl ketene acetals of propargylic acetates have also been reported to undergo facile Ireland-Claisen rearrangement to produce, after hydrolysis, the corresponding allenyl acetic 
acids. ${ }^{58}$ Specifically, the propargylic acetate 204 was treated with lithium diisopropylamide (LDA) followed by trapping the resulting enolate with trimethylsilyl chloride to form the silyl ketene acetal 205 at $-78{ }^{\circ} \mathrm{C}$ (Scheme 46). Upon warming the reaction mixture to $40{ }^{\circ} \mathrm{C}$, the Ireland-Claisen rearrangement occurred to produce the silyl ester 206, which after hydrolysis furnished the allenyl acetic acid $\mathbf{2 0 7}$ in 50\% overall yield.

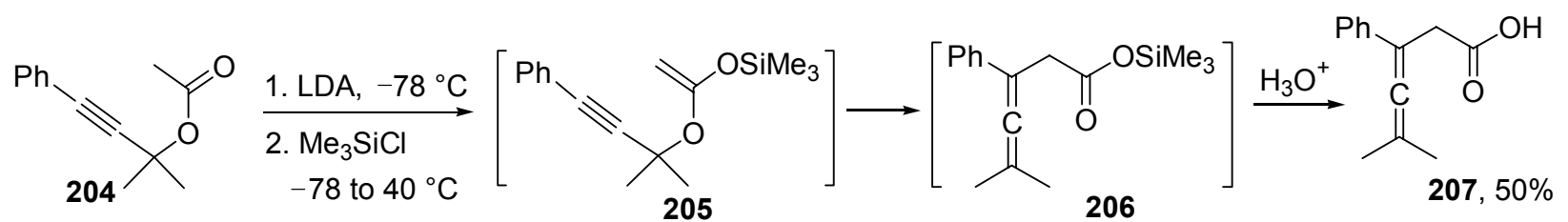

Scheme 46. Allenyl acetic acid 207 via Ireland-Claisen rearrangement.

The discovery and subsequent investigation of the chemistry of buckminsterfullerene $\left(\mathrm{C}_{60}\right)$ have attracted a great deal of interest in bowl-shaped polycyclic aromatic hydrocarbons. As the smallest fullerene fragment, corannulene has received renewed attention. ${ }^{59}$ Recently, development of new synthetic methods for corannulene and related compounds has attracted considerable attention. ${ }^{60}$

\section{Research Objective}

The mildness of the reaction condition and the ready availability of a variety of silyl ketene acetals make the transformation of Ireland-Claisen rearrangement well suited for the preparation of thermally labile enyne-allenes and the benzannulated analogues. However, this reaction sequence did not appear to have been adopted for the synthesis of enyne-allenes. We envisioned that this transformation could be employed to develop a new synthetic strategy to produce in situ the benzannulated enyne-allenes for radical cyclizations leading to polycyclic aromatic compounds. Secondly, we were also interested in exploring the possibility of employing the new polycyclic aromatic compounds to synthesize corannulene and its derivatives via a non-pyrolytic pathway. 
3. Literature Survey for the Synthesis of Benzo[ghi]fluoranthene, Corannulene and Related Compounds, and Synthetic Pathway for Ring Contraction

\subsection{Synthesis of Benzo[ghi]fluoranthene and Related Compounds}

In 1966 and 1971, Barth and Lawton first reported their synthetic approach toward benzo[ghi]fluoranthene, corannulene, and related compounds, which mainly involved intramolecular Friedel-Crafts reactions and an acyloin closure promoted by sodium in inert solvent. ${ }^{61}$ Crombie et al. reported an alternative route to benzo[ghi]fluoranthene via two intramolecular Friedel-Crafts reactions to construct two six-membered rings. ${ }^{62}$ In 1999, Cho et al. reported an alternative pathway to benzo[ghi]fluoranthene (Scheme 47$){ }^{63}$

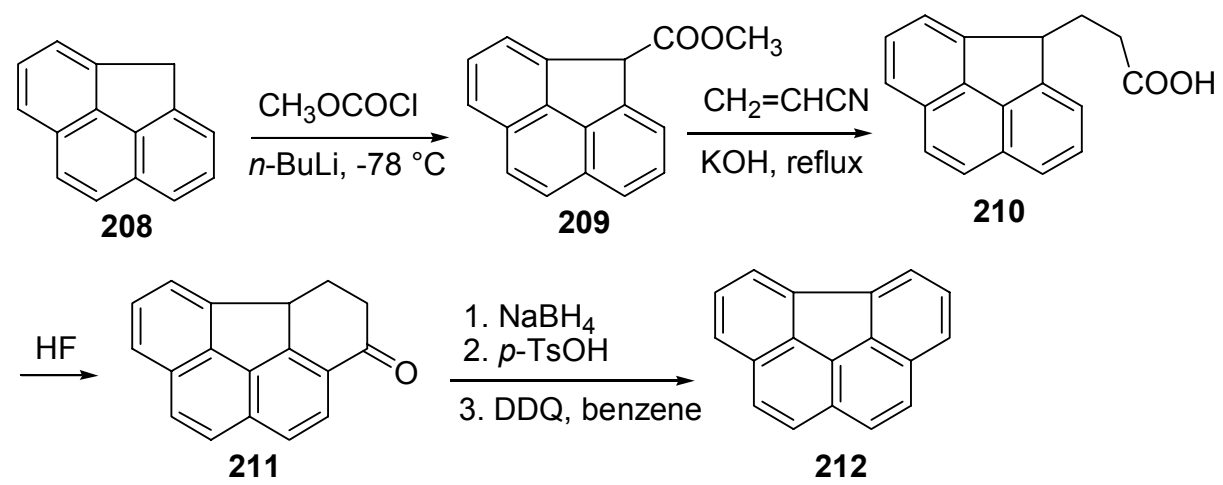

Scheme 47. Cho's approach to 212.

Studt et al. reported a synthetic pathway to benzo[ghi]fluoranthene catalyzed by Pt/C at 400 ${ }^{\circ} \mathrm{C}$ (Scheme 48). ${ }^{64}$

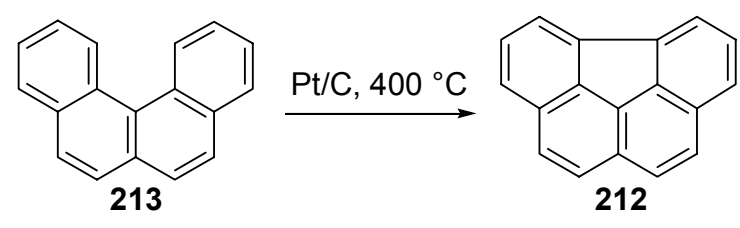

Scheme 48. Studt's approach to 212.

Benzo[ghi]fluoranthene was also prepared via flash vacuum pyrolysis (FVP). Scheme 49 outlines the pyrolytic routes to benzo[ghi]fluoranthene from a variety of starting materials. ${ }^{65}$ 


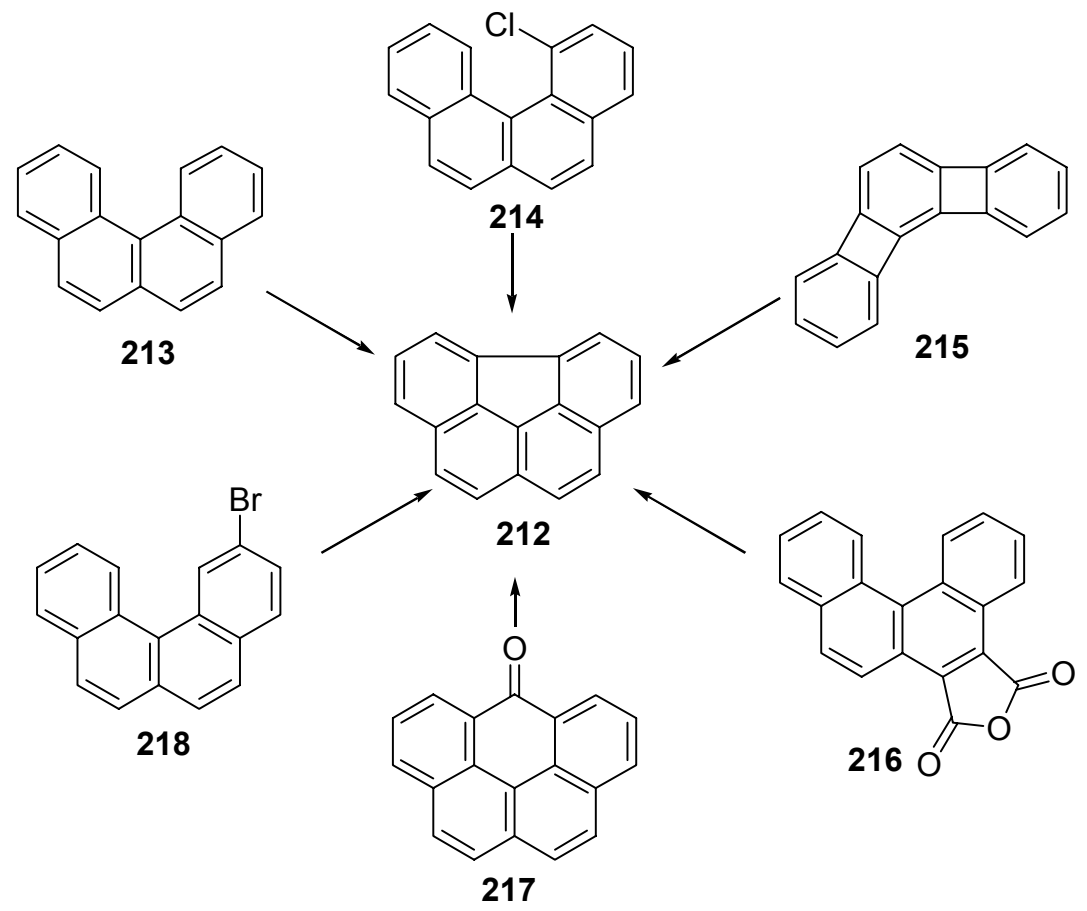

Scheme 49. The syntheses of $\mathbf{2 1 2}$ from a variety of starting metarials via FVP.

\subsection{Synthesis of Corannulene and Related Compounds}

Corannulene was first synthesized by Barth and Lawton in 1966 by a 17 -step process. ${ }^{61}$ This $\mathrm{C}_{20}$ carbon framework, representing the polar cap of buckminsterfullerene $\left(\mathrm{C}_{60}\right)$, has attracted renewed interest in the development of efficient pathways for its synthesis. Several attempts to improve the synthesis were unsuccessful ${ }^{66}$ until Scott et al. first successfully applied flash vacuum pyrolysis methodology to the ring-forming step leading to corannulene in $1991 .{ }^{59}$

\subsubsection{Synthesis of Corannulene via Flash Vacuum Pyrolysis (FVP)}

Scott et al. reported a readily accessible process to corannulene 221 via FVP (Scheme $50){ }^{59}$

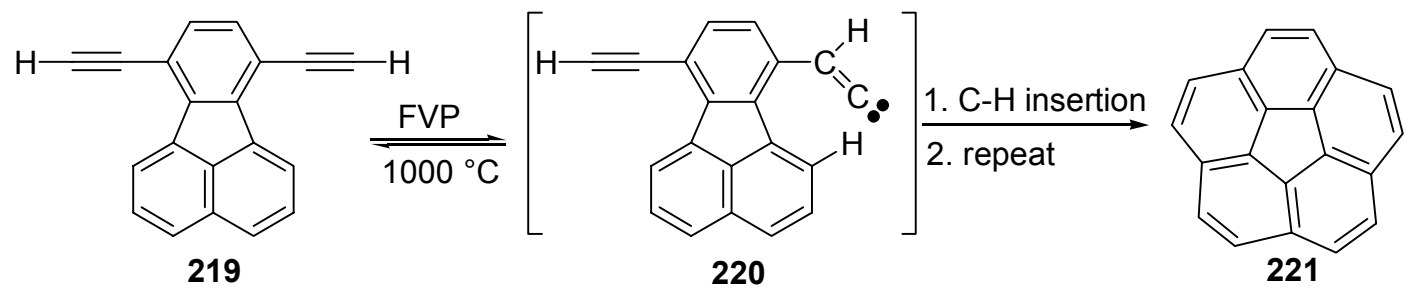

Scheme 50. The first synthesis of corannulene 221 via FVP. 
During the past several years, several syntheses of corannulene 221 and related bowlshaped compounds via FVP were reported (Scheme 51). ${ }^{60}$ In these syntheses, the central fivemembered ring is pre-formed and two six-membered aromatic rings are formed via the key FVP process.

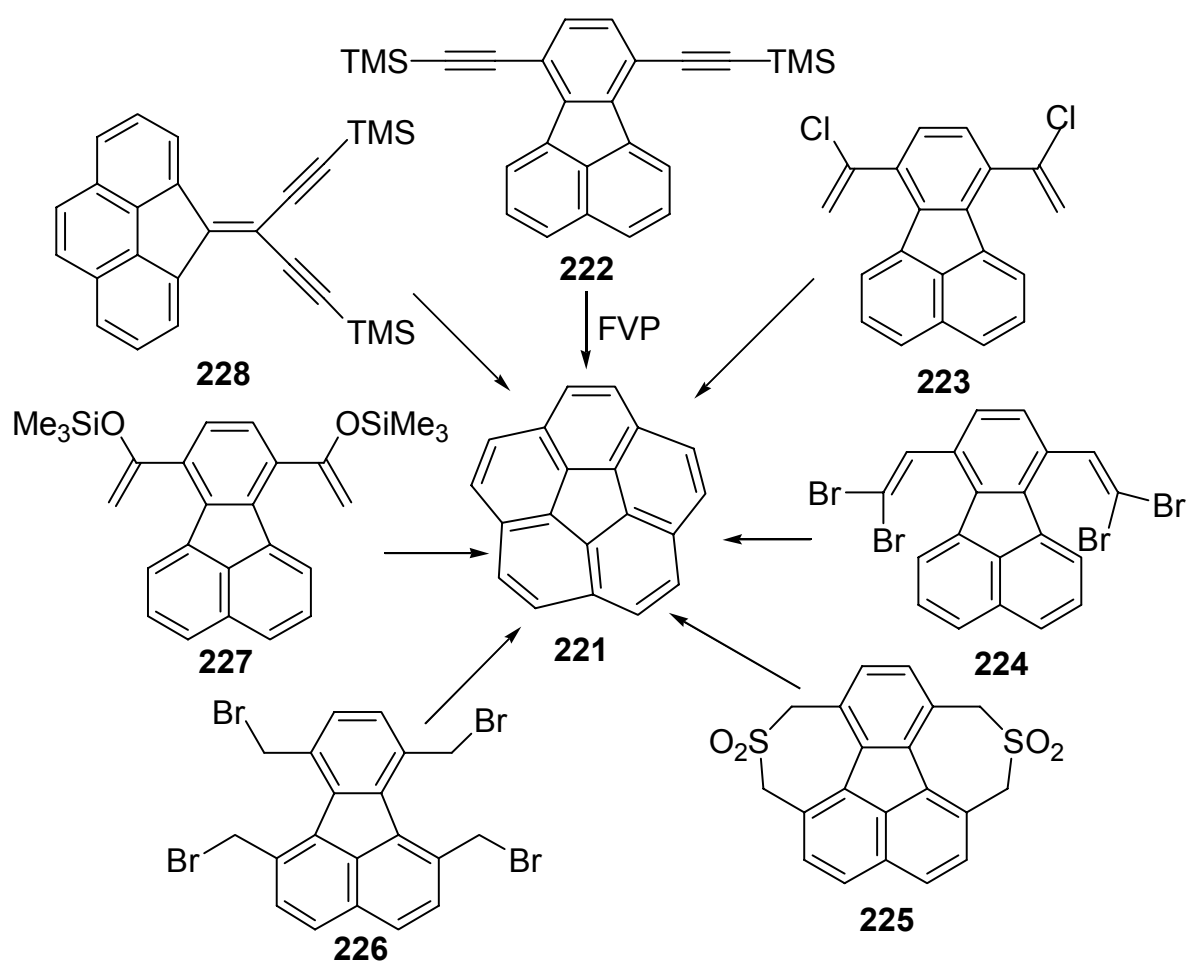

Scheme 51. The syntheses of 221 from a variety of starting metarials via FVP.

Mehta et al. reported an alternative approach to corannulene $\mathbf{2 2 1}$ by employing simple starting materials and basic reactions, and generating a five- and a six-membered ring via FVP step (Scheme 52). ${ }^{60 \mathrm{~h}, 67}$

Although FVP method is successful for the synthesis of several buckybowls in moderate to low yield, ${ }^{68 a}$ it suffers from a few disadvantages, such as low yields for larger, nonvolatile systems; difficulties to scale up; and a lack of functional group tolerance. ${ }^{6 \mathrm{~b}}$ 


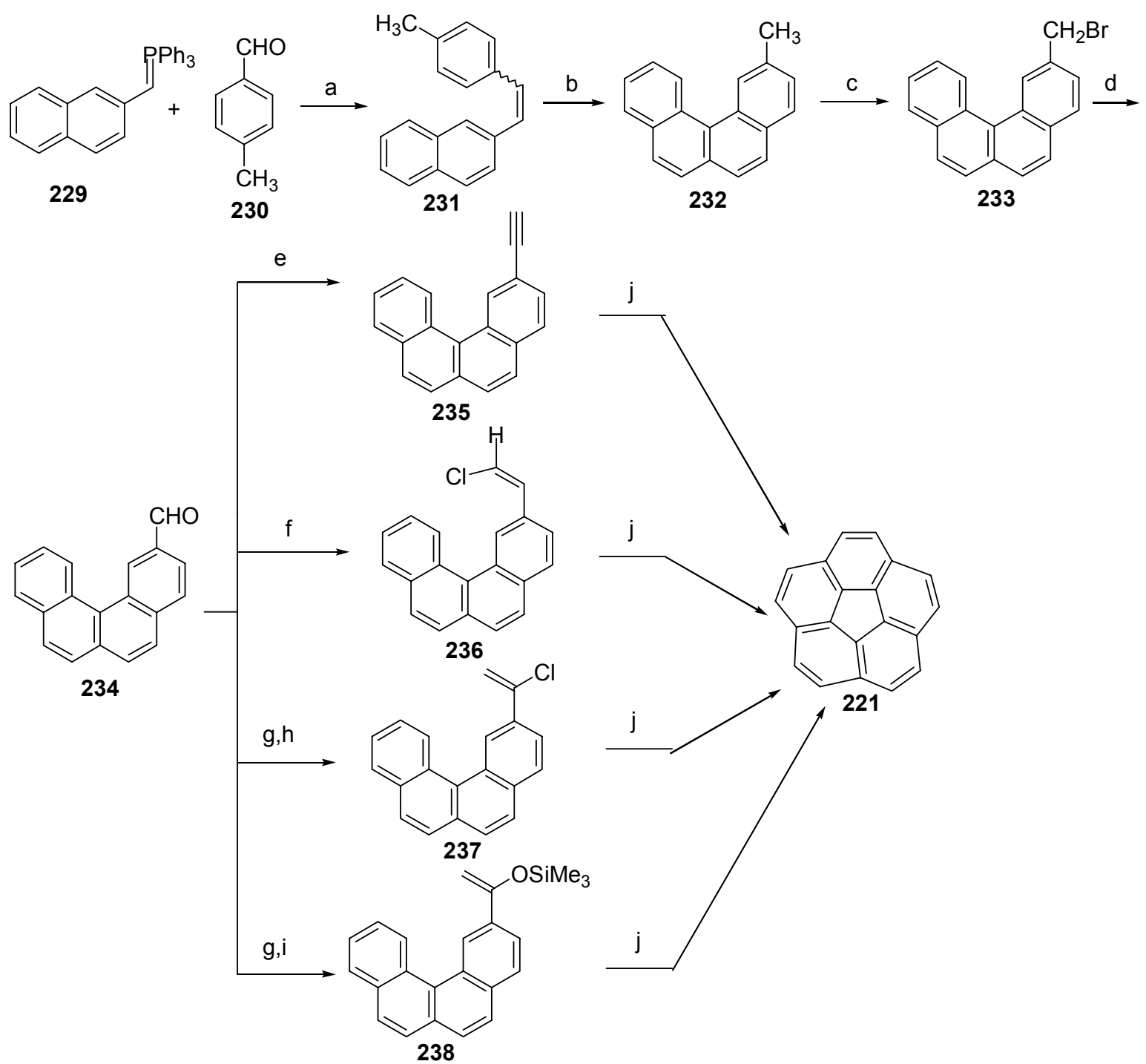

Reagents and yeild: a. $\mathrm{K}_{2} \mathrm{CO}_{3}$, THF, 18-crown-6, 65\%; b. hv, $\mathrm{C}_{6} \mathrm{H}_{6}$, I , propylene oxide, 2 h, 35\%; c. NBS, $\mathrm{CCl}_{4}$, AIBN, 75\%; d. $\left(\mathrm{Bu}_{4} \mathrm{~N}\right)_{2} \mathrm{Cr}_{2} \mathrm{O}_{7}, \mathrm{CHCl}_{3}, 60 \%$; e. $\mathrm{ClCH}_{2} \mathrm{PPh}_{3}{ }^{+} \mathrm{Cl}^{-}, t-\mathrm{BuO}^{-} \mathrm{K}^{+}, 2$ h, $60 \%$; f. $\mathrm{ClCH}_{2} \mathrm{PPh}_{3}{ }^{+} \mathrm{Cl}^{-}$, $t$-BuO`K${ }^{+}, 0.5$ h, 70\%; g. (i) $\mathrm{CH}_{3} \mathrm{Mgl}$, THF, 0.5 h, 80\%; (ii) PCC, DCM, 2 h, $60 \%$; h. $\mathrm{PCl}_{5}, \mathrm{C}_{6} \mathrm{H}_{6}, 40 \%$; i. LDA, THF, TMSCI, $60 \%$; f. FVP, $1200^{\circ} \mathrm{C}, 0.5$ torr, $\mathrm{N}_{2}$ flow.

Scheme 52. Mehta's approach to corannulene 221 via FVP.

\subsubsection{Synthesis of Corannulene and Related Compounds via Non-pyrolytic Pathway}

In 1996, Siegel et al. first reported that the corannulene derivatives could be prepared via non-pyrolytic pathway involving the formation of the two rim bonds via reductive coupling with $\mathrm{TiCl}_{3} / \mathrm{LiAlH}_{4}$ or $\mathrm{VCl}_{3} / \mathrm{LiAlH}_{4}$ (Scheme 53). ${ }^{69}$ This method was adopted for synthesis of more complex corannulene derivatives. ${ }^{70}$ 


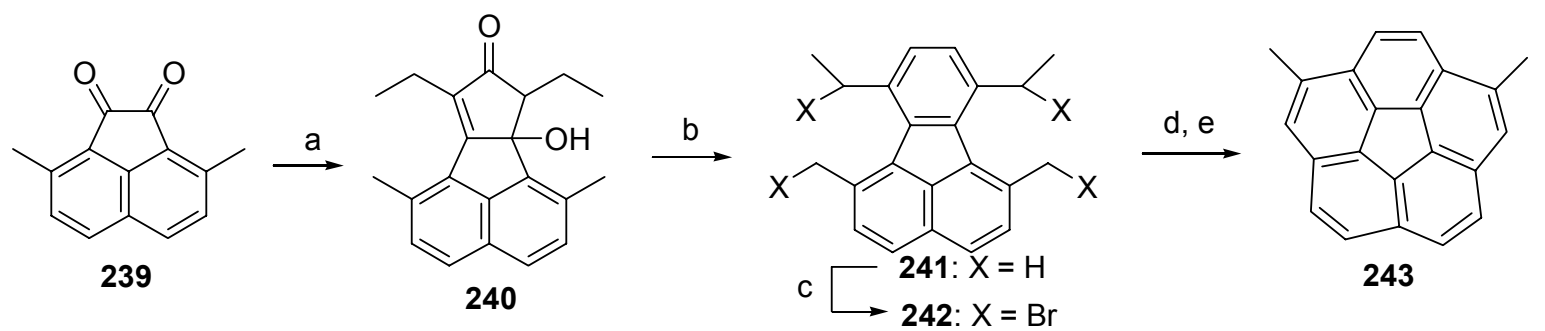

Conditions: a. 4-heptanone, $\mathrm{KOH}$; b. norbornadiene, acetic anhydride (49\%, 2 steps); c. NBS, benzoylperoxide, hv (quantitative); d. $\mathrm{TiCl}_{3}$, $\mathrm{LiAlH}_{4}$ (33\%); e. DDQ, (55\%).

Scheme 53. Siegel's non-pyrolytic pathway to 243.

In 2000, Rabideau et al. reported an inexpensive, convenient synthesis of corannulene and its derivatives in over $80 \%$ yield and mild conditions where reaction mixtures were refluxed for $15 \mathrm{~min}$ in aqueous dioxane containing $\mathrm{NaOH}$ (Scheme 54). ${ }^{71}$

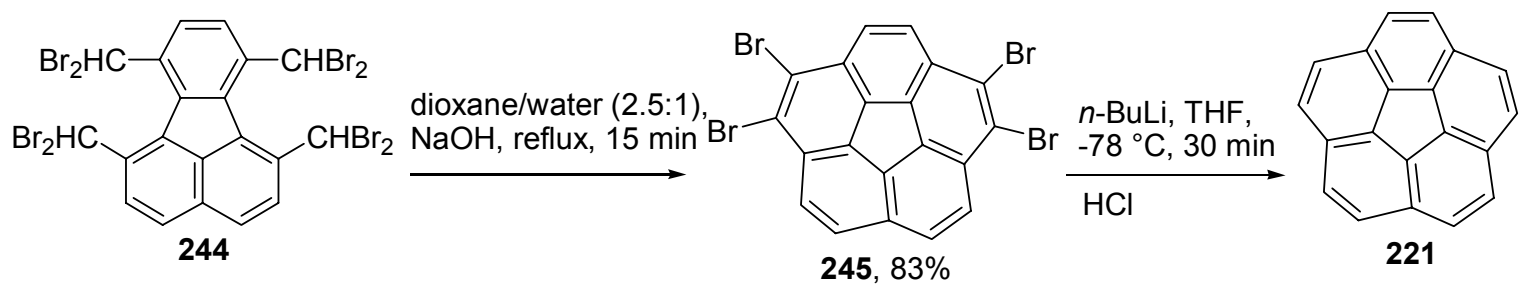

Scheme 54. Rabideau's improved approach to 221 via non-pyrolytic pathway.

Scott et al. developed a new route to dibenzo[a,g]corannulene by intramolecular palladium-catalyzed arylation reactions (Scheme 55$)^{72,68 a}$

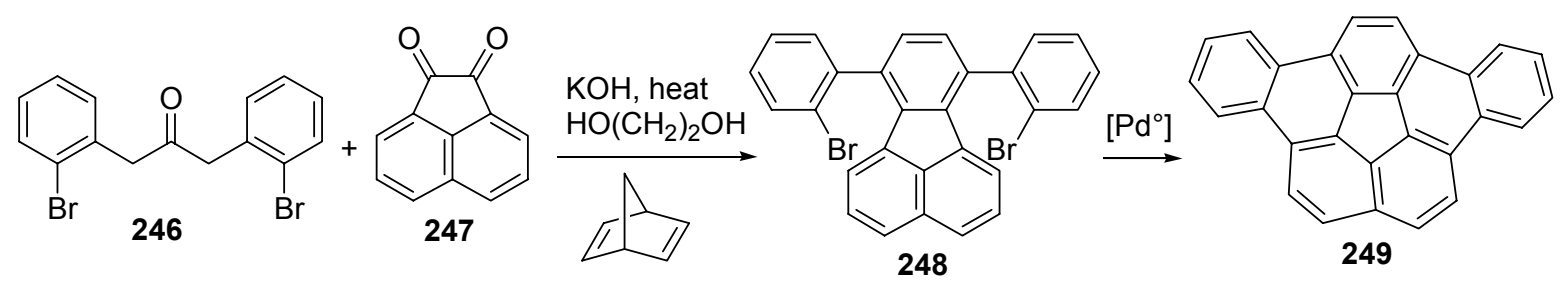

Scheme 55. Scott's approach to 249 via non-pyrolytic pathway.

Rabiduau et al. recently discovered that the formation of the two rim bonds could be promoted by nickel-mediated intramolecular coupling of benzyl and benzylidene bromides (Scheme 56). ${ }^{68 b, 73}$ 


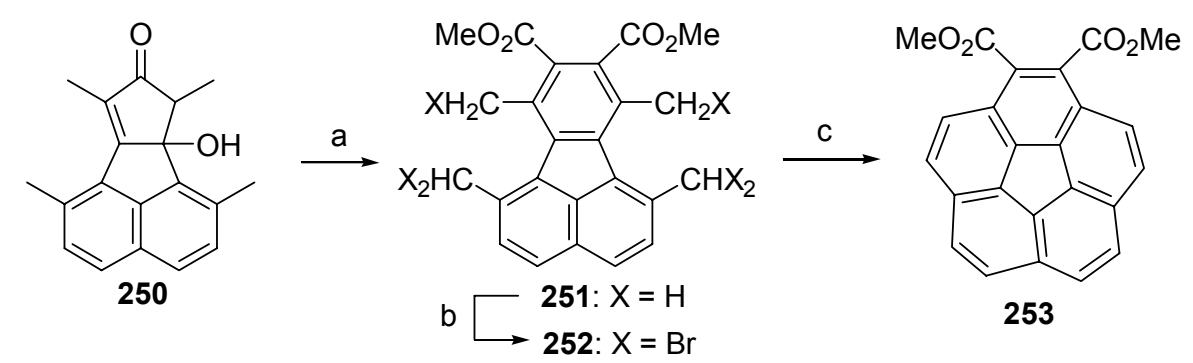

Conditions: a. (i) acetic anhydride, $\mathrm{H}_{2} \mathrm{SO}_{4}, 1 \mathrm{~h}$, rt; (ii) dimethyl acetylene dicarboxylate, $2 \mathrm{~h}$ reflux, $(75-80 \%)$;

b. $\mathrm{CCl}_{4}, \mathrm{NBS}$, benzoylperoxide, hv, $2 \mathrm{~h}$, reflux (quantitative); c. DMF, Ni powder, $12 \mathrm{~h}, 80-90{ }^{\circ} \mathrm{C}(60 \%)$.

Scheme 56. Rabideau's approach to 253 catalyzed by Ni(0).

\subsection{Synthetic Pathway for Ring Contraction}

\subsubsection{Ring Contraction via Lead(IV) Acetate}

Taylor et al. reported an oxidative rearrangement of alkyl aryl ketone under mild conditions by using thallium(III) nitrate leading to corresponding methyl arylacetate in good yield. This method was adopted for ring contraction. ${ }^{74}$ Following this report, a ring contraction method using lead(IV) acetate in the presence of boron trifluoride and methanol appeared. ${ }^{75} \mathrm{~A}$ specific example including the reaction mechanism is outlined in Scheme $57 .{ }^{75 a}$
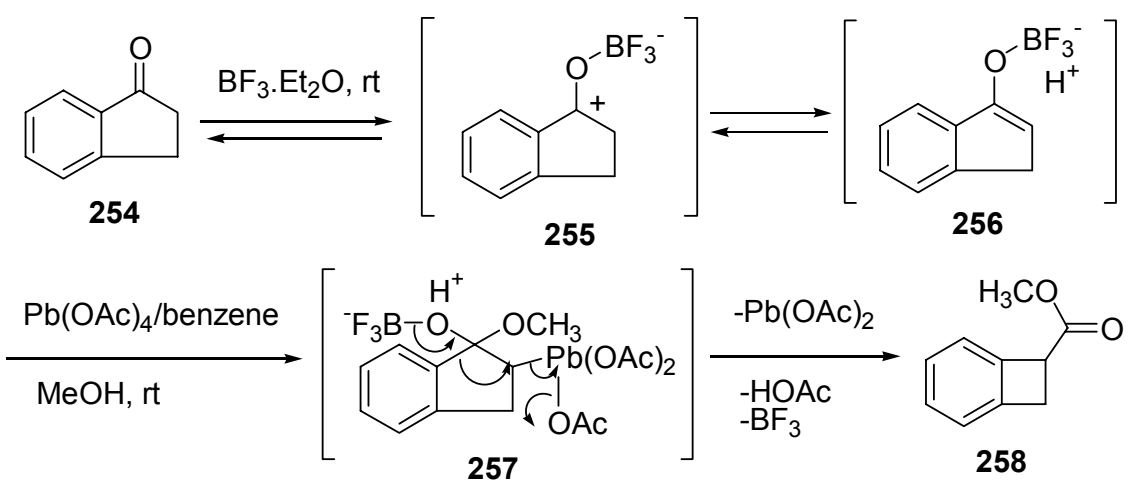

Scheme 57. Ring contraction catalyzed by $\mathrm{Pd}(\mathrm{OAc})_{4}$.

A ring contraction of aliphatic cycloketones was reported by Myrboh, which was carried out in the presence of perchloric acid, triethyl orthoformate, and lead(IV) acetate (Scheme 58). ${ }^{76}$

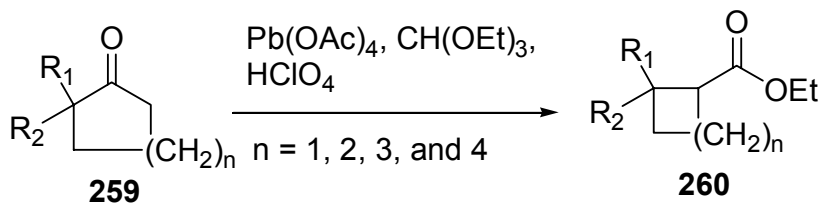

Scheme 58. Ring contraction of aliphatic cycloketones catalyzed by $\operatorname{Pd}(\mathrm{OAc})_{4}$. 


\subsubsection{Ring Contraction via Wolff Rearrangement}

Ring contraction via Wolff rearrangement of diazo ketones has been applied to the synthesis of several highly strained ring systems. ${ }^{77}$ It is successful in the construction of the 4and 5-membered rings (Scheme 59). ${ }^{77 a}$ Generally, the synthesis of diazo ketones involved the reaction sequence of the preparation of formyl derivatives followed by treatment with tosyl or mesyl azide. ${ }^{77 a, e, f, 78}$ An alternative synthetic pathway to diazo ketones involved a two-step reaction sequence using isoamylnitrite and chloramine (Scheme 60). ${ }^{77 \mathrm{c}, \mathrm{d}, 79}$

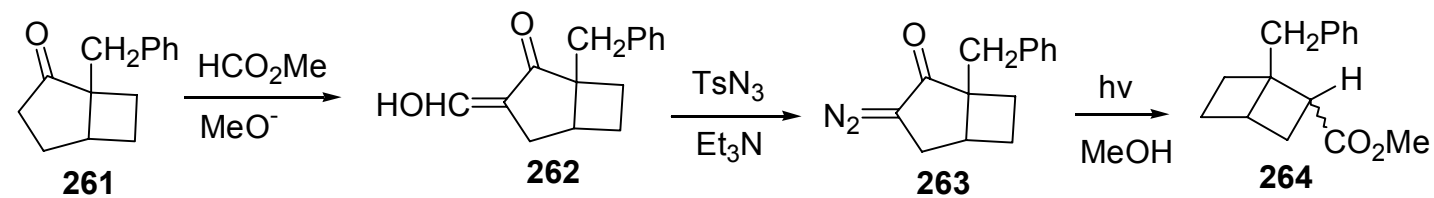

Scheme 59. Ring contraction via Wolff rearrangement.

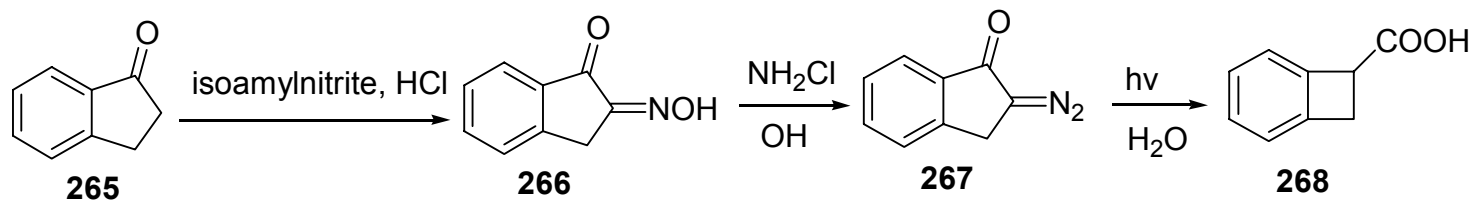

Scheme 60. An alternative pathway to the diazo ketone and ring contraction.

\section{Results and Discussion}

\subsection{Polycyclic Aromatic Carboxylic Acids via Ireland-Claisen Rearrangement}

Condensation between 9-fluorenone and the lithium acetylide $\mathbf{6 0}^{33}$ as reported previously furnished the corresponding alkoxide, ${ }^{32 \mathrm{~b}}$ which was captured by acetic anhydride to afford the propargylic acetate 190 (Scheme 61). Treatment of 190 with LDA at $-78{ }^{\circ} \mathrm{C}$ followed by trapping the resulting enolate with tert-butyldimethylsilyl chloride (TBDMSCl) then gave the silyl ketene acetal 269. ${ }^{80}$ A series of reactions then occurred upon warming the reaction mixture to $45^{\circ} \mathrm{C}$, including an Ireland-Claisen rearrangement to form the benzannulated enyne-allene 270 followed by a Schmittel cyclization to generate the benzofulvene biradical 271. An intramolecular radical-radical coupling then produced the formal Diels-Alder adduct 272, which 
in turn underwent a prototropic rearrangement to give the silyl ester $\mathbf{2 7 3}$ and, after hydrolysis, the carboxylic acid 274 in $57 \%$ overall yield from 190 in a single operation. The cascade transformation from $\mathbf{2 7 0}$ to $\mathbf{2 7 3}$ is reminiscent of what was observed previously in a chlorinated enyne-allene system derived from condensation between 9-fluorenone and $\mathbf{6 0}$ to form the corresponding propargylic alcohol followed by treatment of the propargylic alcohol with thionyl chloride. ${ }^{32 b}$

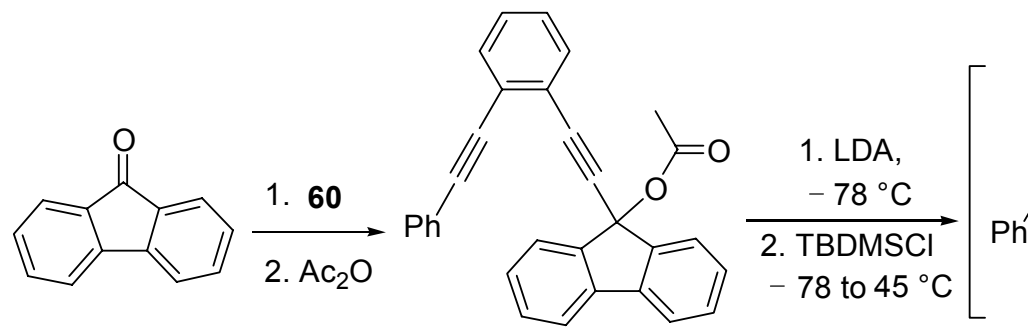

$190,83 \%$

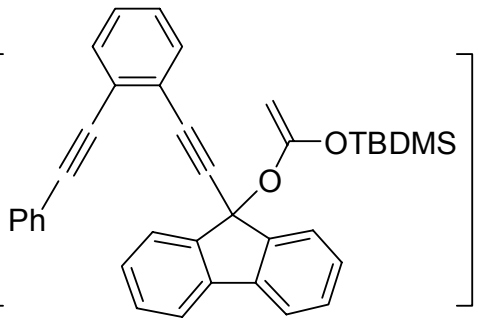

269<smiles>CCOC(=O)CC(=C=C1c2ccccc2-c2ccccc21)c1ccccc1C#CCc1ccccc1</smiles><smiles>CCC</smiles><smiles></smiles>
271

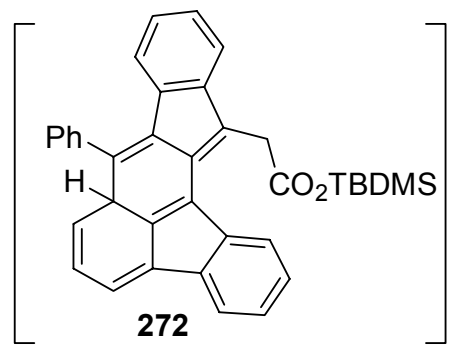

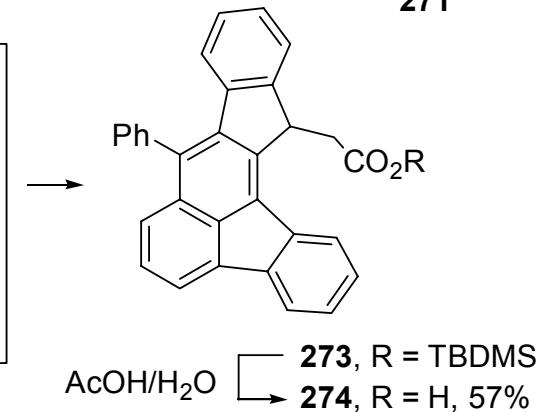

Scheme 61. Synthesis of 274 via Ireland-Claisen rearrangement.

The diaryl ketone $\mathbf{2 7 5},{ }^{81}$ readily obtained by oxidation of the corresponding hydrocarbon, $4 H$-cyclopenta $[$ def $]$ phenanthrene, ${ }^{82}$ was also selected for condensation with $\mathbf{6 0}$ leading to the propargylic acetate $\mathbf{2 7 9}$ in $81 \%$ yield (Table 3). The acetate $\mathbf{2 7 9}$ was converted to the carboxylic acid $\mathbf{2 8 3}^{83}$ via the tandem sequence of Ireland-Claisen rearrangement and Schmittel cyclization. Similarly, the use of the diaryl ketone $\mathbf{2 7 6},{ }^{59 a, 84}$ benzophenone (277), and dibenzosuberone (278) 
led to the carboxylic acids $\mathbf{2 8 4}, \mathbf{2 8 5}$, and $\mathbf{2 8 6}$, respectively. As a result of lower stability of $\mathbf{2 8 2}$, the carboxylic acid $\mathbf{2 8 6}$ was produced in low yield. It is worth noting that the structures of $\mathbf{2 8 3}$ and 284 contain a benzo[ghi]fluoranthene unit and a dihydrobenzo[ghi]fluoranthene unit, respectively. Several synthetic methods for benzo[ghi]fluoranthene and related derivatives have been reported. ${ }^{59,60,61,62,63}$ One of these derivatives was used in the first synthesis of the bowlshaped corannulene. ${ }^{59}$

Table 3. Synthesis of Polycyclic Aromatic Carboxylic Acids from Diaryl Ketones

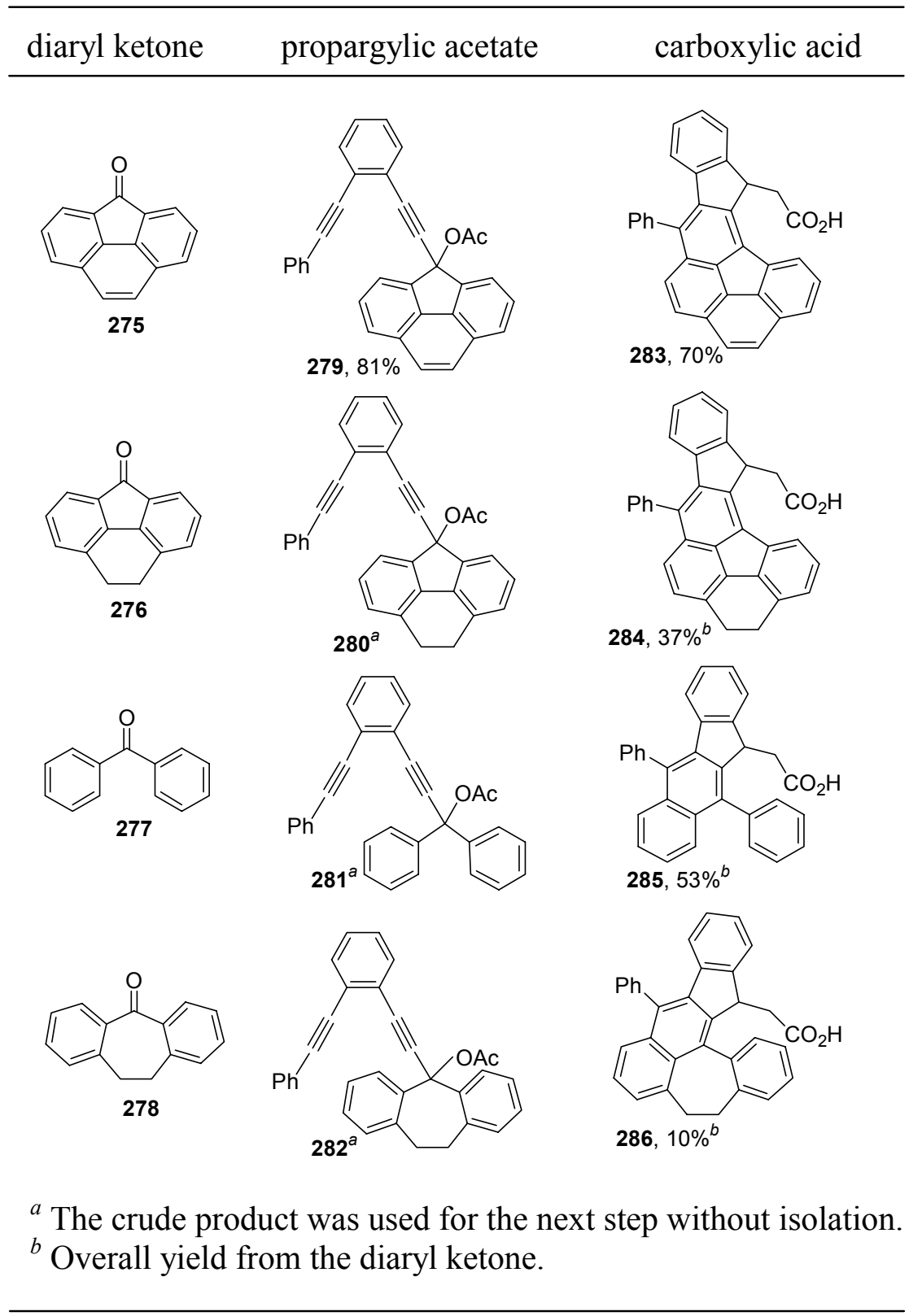




\subsection{Synthesis of Polycyclic Ketone via Friedel-Crafts Reaction and Attempts to Synthesize}

\section{Corannulene Derivatives}

The pendent carboxylic acid group in $\mathbf{2 7 4}$ also provided the opportunity for an intramolecular acylation reaction. Conversion of $\mathbf{2 7 4}$ to the corresponding acid chloride with thionyl chloride followed by an aluminum chloride-promoted intramolecular acylation reaction then produced the polycyclic aromatic ketone $\mathbf{2 8 7}$ in $88 \%$ yield (eq 1). The structure of $\mathbf{2 8 7}$ was established by X-ray structure analysis.
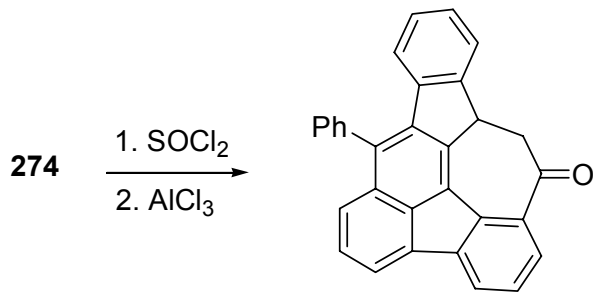

eq 1

$287,88 \%$

The acid $\mathbf{2 8 3}$ was also readily converted to the acid chloride $\mathbf{2 8 8}$ with thionyl chloride (Scheme 62). However, attempts to promote the intramolecular acylation reaction of $\mathbf{2 8 8}$ using aluminum chloride as a catalyst to form $\mathbf{2 8 9}$ were unsuccessful. The ${ }^{1} \mathrm{H}$ NMR spectrum of the crude reaction mixture showed only very broad peaks in the aromatic region indicating that intermolecular acylation occurred to give polymerized adducts. It was envisioned that $\mathbf{2 8 9}$ could serve as a precursor for ring contraction $^{74,75 a, 77 a}$ to form $\mathbf{2 9 0}$ having an indeno-fused dihydrocorannulene moiety. The acid chloride of $\mathbf{2 8 4}$ was also used for the acylation reaction in the hope that the intermolecular reaction could be avoided. Unfortunately, such an attempt was also unsuccessful. Treatment of $\mathbf{2 8 4}$ with concentrated sulfuric acid at room temperature for 12 $\mathrm{h}$ resulted in the recovery of unreacted $\mathbf{2 8 4}$. On the other hand, the aryl ketone $\mathbf{2 9 1}{ }^{85}$ was readily obtained from 285 in $70 \%$ yield (eq 2). 


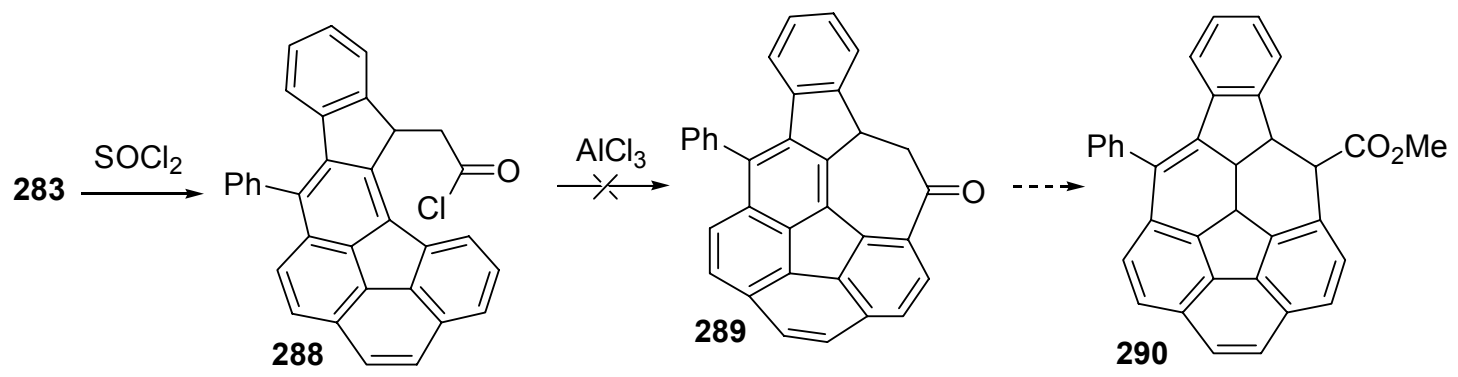

Scheme 62. Attempt to synthesize $\mathbf{2 8 9}$ by acylation reaction.

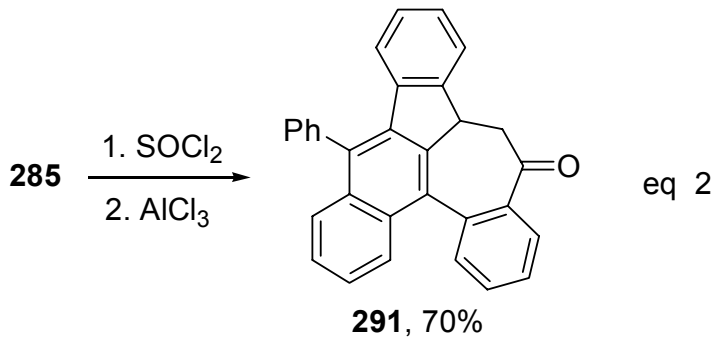

\section{3. $[4+2]$ versus $[2+2]$ Cyclization}

With the propargylic acetate 293, derived from 2,2-dimethylpropiophenone (292), the $1 H$-cyclobut $[a]$ indenyl acetic acid $\mathbf{2 9 6}$ was obtained as the predominant product along with ca. $1 \%$ of the $11 H$-benzo[b]fluorenyl acetic acid 297 (Scheme 63). Conceivably, the initially formed benzannulated enyne-allene 294 underwent a $[2+2]$ cycloaddition reaction preferentially, perhaps also via the biradical 295, to produce 296 . The low propensity for 295 to undergo the radical-radical coupling reaction involving a double bond of the phenyl substituent to produce the formal Diels-Alder adduct leading to $\mathbf{2 9 7}$ may be attributed to the emergence of the nonbonded steric interactions between the silyl ester group and the tert-butyl group depicted in 295 along the pathway toward 297. Such a change of the reaction pathway was also observed previously in the chlorinated enyne-allene system. ${ }^{32 b}$ 

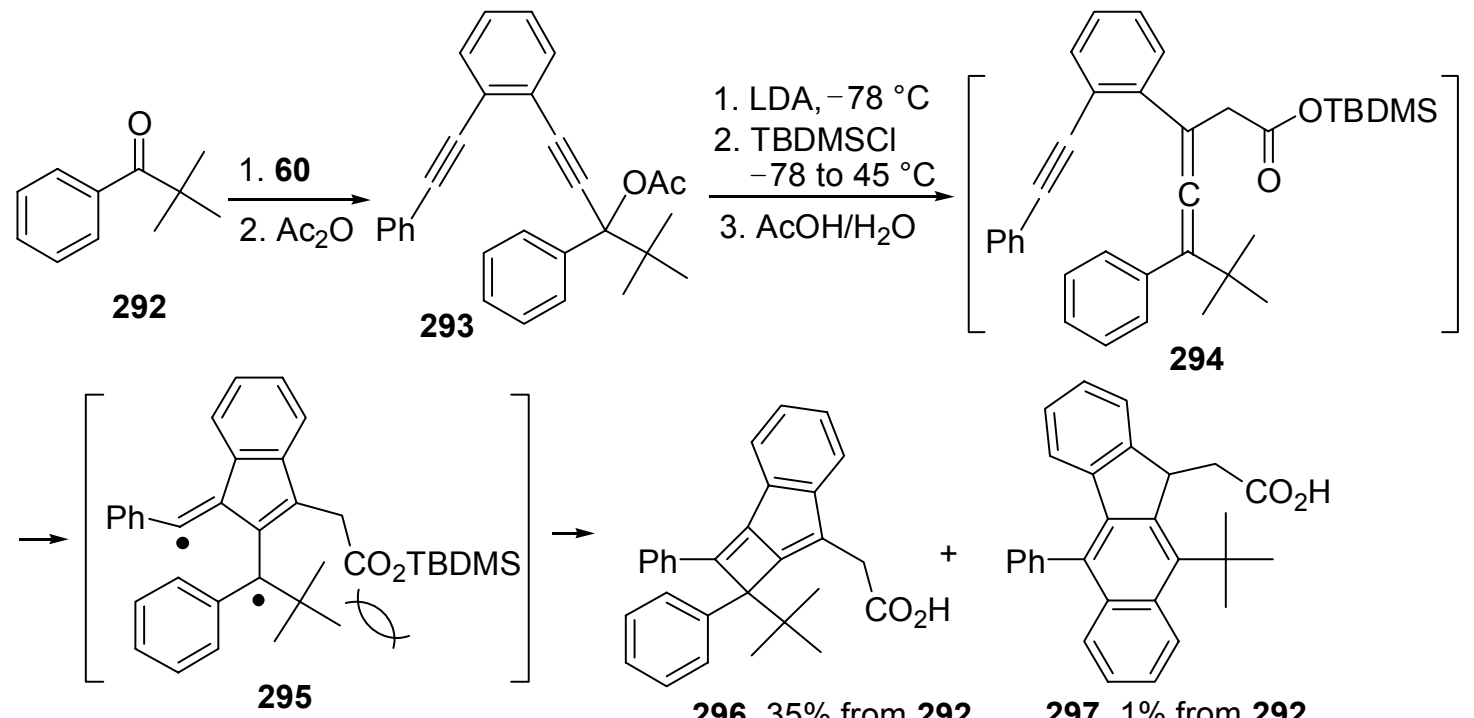

296, 35\% from 292

297, $1 \%$ from 292

Scheme 63. $[2+2]$ cyclization of 293 via Ireland-Claisen rearrangement.

As in the case of the chlorinated enyne-allene system, the use of the ketone $\mathbf{2 9 8}^{86}$ having the keto group incorporated in the six-membered ring to prepare the propargylic acetate $\mathbf{3 0 0}$ for the cascade transformation appears to reduce the nonbonded steric interactions along the pathway leading to the Diels-Alder adduct (Scheme 64). As a result, the $[2+2]$ cycloaddition adduct $\mathbf{3 0 2}$ and the Diels-Alder adduct $\mathbf{3 0 3}$ were produced in essentially equal amounts. In the case of 301, prepared from $\mathbf{2 9 9}^{87}$ having a five-membered ring, the effect was particularly dramatic and resulted in the formation of the Diels-Alder adduct $\mathbf{3 0 5}$ predominantly.

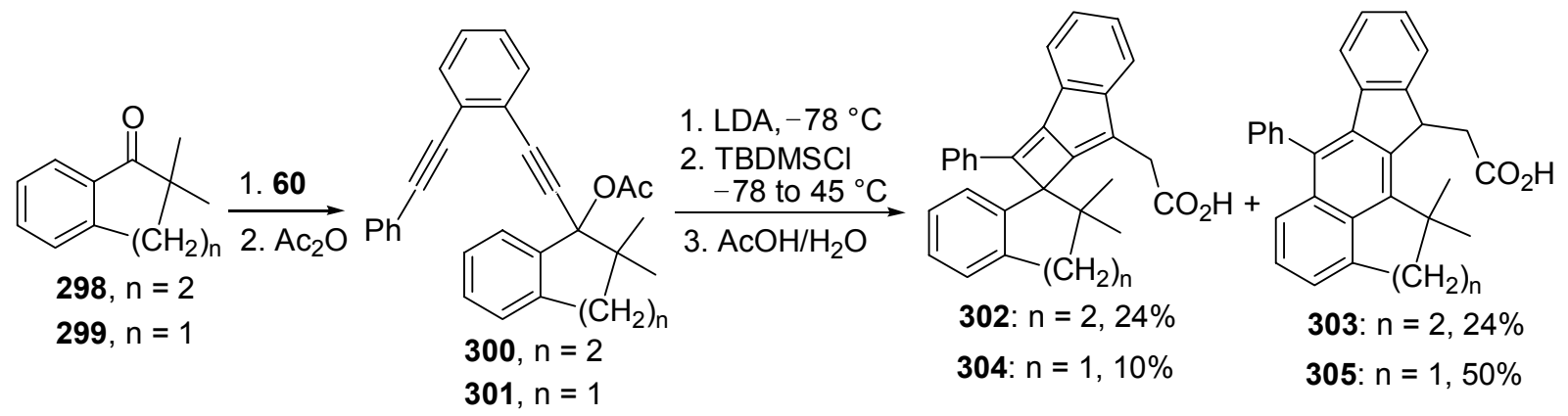

Scheme 64. $[4+2]$ vs $[2+2]$ cyclization. 


\subsection{Attempts for Ring Contraction}

\subsubsection{Attempts for Ring Contraction Catalyzed by $\mathrm{Pb}(\mathrm{OAc})_{4}$}

Scheme 65 outlines an attempt for ring contraction to form 307 using $\mathrm{Pb}(\mathrm{OAc})_{4}{ }^{75 \mathrm{a}}$ First, the reaction was carried out in benzene. The starting material 287 was recovered due to the very low solubility of $\mathbf{2 8 7}$. To increase the solubility of $\mathbf{2 8 7}$, the reaction was performed in a mixture of methylene chloride and benzene. It was quite unexpected that compound $\mathbf{3 0 6}$ was produced in 37\% yield. The structure of $\mathbf{3 0 6}$ was established by X-ray structure analysis. The reaction mechanism is not clear at the present time.<smiles></smiles>

287
$\frac{\mathrm{BF}_{3} \cdot \mathrm{Et}_{2} \mathrm{O}, \mathrm{MeOH}, \mathrm{CH}_{2} \mathrm{Cl}_{2}}{\mathrm{~Pb}(\mathrm{OAc})_{4}, \text { Benzene, reflux }}$

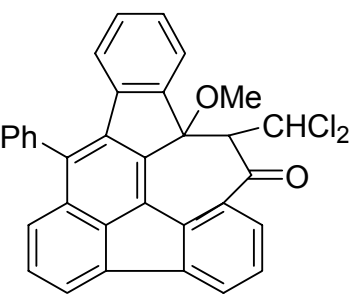

$306,37 \%$

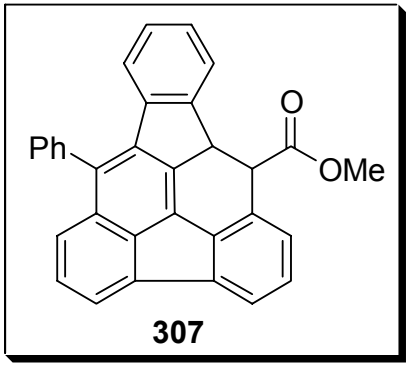

307

Scheme 65. Attempt to form $\mathbf{3 0 7}$ via ring contraction catalyzed by $\mathrm{Pb}(\mathrm{OAc})_{4}$.

Scheme 66 outlines an alternative attempt for ring contraction. Compound $\mathbf{3 0 9}$ was produced successfully from benzosuberone by using the method reported previously for the ring contraction of aliphatic cycloketones. ${ }^{76 a}$ When the same reaction condition was employed for compound 287, compound $\mathbf{3 1 0}$ was isolated, and part of starting material was recovered. The structure of $\mathbf{3 1 0}$ was established by X-ray structure analysis. 


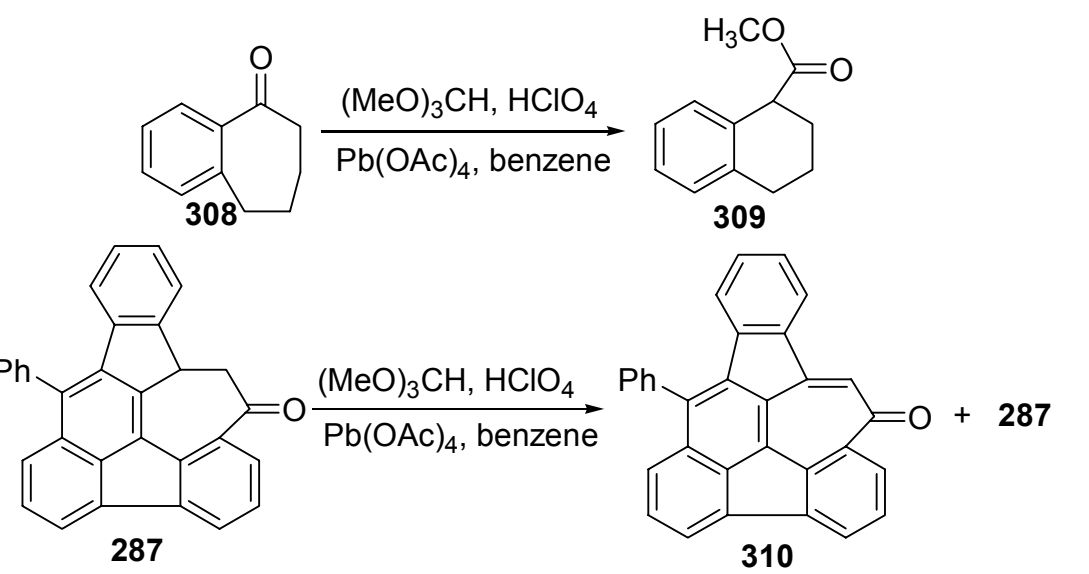

Scheme 66. Model compound study and the second attempt to form $\mathbf{3 0 7}$.

\subsubsection{Attempts for Ring Contraction via Wolff Rearrangement}

Scheme 67 outlines an attempt for ring contraction via Wolff rearrangement. We were able to successfully carry out the ring contraction of $\mathbf{3 1 1}$ via the general reaction sequences of Wolff rearrangement as reported previously. ${ }^{77}$ However, compound $\mathbf{3 1 0}$ was again isolated using two different procedures for the preparation of the diazo ketone followed by ring contraction. Treatment of $\mathbf{2 8 7}$ with $\mathrm{NaH}, \mathrm{MeOH}$, and methyl formate furnished $\mathbf{3 1 0}$ instead of the corresponding formyl derivatives. Attempts to produce the diazo ketone via a one-pot procedure resulted in $\mathbf{3 1 0}$ as well.

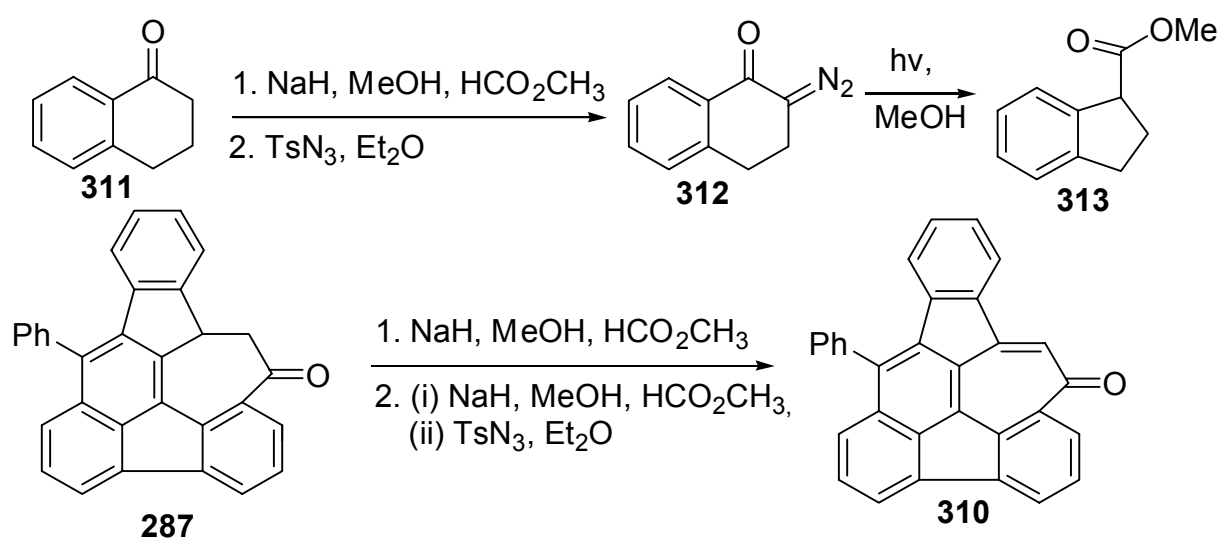

Scheme 67. Model compound study of Wolff rearrangement and attemp to prepare the diazo ketone.

Scheme 68 outlines an alternative pathway to prepare the diazo ketone ${ }^{79}$ for the following Wolff rearrangement. It was also unsuccessful. 


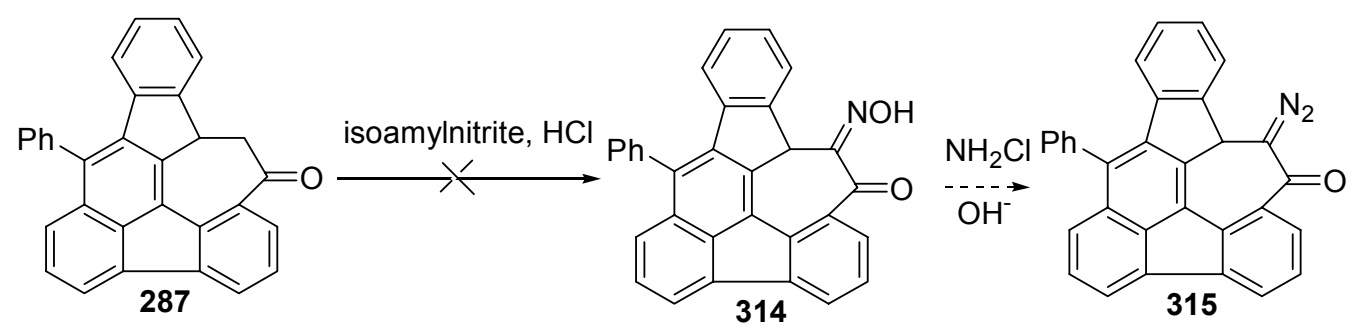

Scheme 68. An alternative attempt to prepare the diazo ketone.

\section{Conclusions}

The Ireland-Claisen rearrangement of the propargylic acetates was successfully adopted for the synthesis of the benzannulated enyne-allenes in situ for the subsequent Schmittel cyclization to generate benzofulvene biradicals for a cascade sequence of reactions. Several polycyclic aromatic derivatives of benzo[ghi]fluoranthene and $11 H$-benzo[b]fluorene were thus produced. In several cases, the $[2+2]$ cycloaddition reaction of the benzannulated enyne-allenes also occurred leading to the corresponding $1 H$-cyclobut $[a]$ indenyl acetic acids. While several attempts for ring contraction of compound $\mathbf{2 8 7}$ and intramolecular acylation of polycyclic aromatic carboxylic acids 283 and 284 were unsuccessful, many other potential Lewis-acid catalysts other than $\mathrm{AlCl}_{3}$ are available for intramolecular acylation reactions, and will be used in future studies. The highly efficient pathway outlined in Scheme $61 \&$ eq 1 holds great promise for the synthesis of a wide variety of polycyclic aromatic compounds. 


\section{CHAPTER IV}

\section{Polycyclic Compounds via Wagner-Meerwein Rearrangement of Fluorenylmethanols and Intramolecular Friedel-Crafts Arylation Reactions}

\section{Introduction}

Screw structures or helices are encountered frequently in nature. In addition to the helical molecules in biochemistry including nucleic acids, proteins, and polysaccharides, more and more unnatural helical molecules, such as helical alkenes, phenanthrenes, helicenes, and ariliphatic helices, have been reported. ${ }^{88 a, b}$ Among the unnatural helices, helicenes, as helical compounds consisting of ortho-fused aromatic rings, were regarded as little more than an academic curiosity for many years. ${ }^{88}$ Helicenes have received great attention recently, because of their unique properties associated with their inherent chirality due to their nonplanar structures. $^{89} \quad[\mathrm{n}]$ Helicenes were considered potentially useful for asymmetric catalysts, ${ }^{90}$ asymmetric molecular recognition, ${ }^{91}$ liquid crystals, ${ }^{92}$ novel optical materials, owing to the extraordinary optical and electronic properties, ${ }^{93}$ self-assembling components, ${ }^{94}$ and molecular devices. $^{95}$ Figure 6 displays some examples of phenanthrenes, helicenes and related compounds having unique properties. 4,5-Disubstituted phenanthrenes 316 have inherently helical chirality because of steric hindrance. ${ }^{96}$ An enantiopure [6] carbohelicene $\mathbf{3 1 7}$ was used successfully for catalyzing enantioselective synthesis of pyrimidyl alkanol. ${ }^{90 a}$ Phosphine $\mathbf{3 1 8}$ as a chiral ligand was prepared and employed as a catalyst for enantioselective hydrogenation. ${ }^{90 \mathrm{~b}, \mathrm{c}}$ Compounds 319 and 320 classified as heterohelicene and helicenequinone, respectively, were found to possess nonlinear optical property. ${ }^{93 a, c, d}$ In addition, 320 could also serve as the precursor for other novel materials, such as liquid crystal, conjugated ladder polymer, and helicene fibers. ${ }^{92}$ 
Compound 321, a $[P]$ helicene, binds to DNA strongly and forms more stable complex than the corresponding $[M]$ helicene. ${ }^{91 a}$ Due to their unique properties and potential applications as novel materials, development of efficient methods for the synthesis of phenanthrenes and helicenes in large scale and in good enantioselectivity has attracted considerable attention. ${ }^{88 \mathrm{e}}$

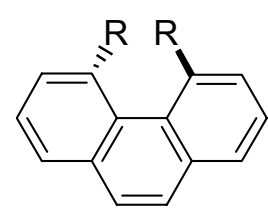

$\mathrm{R}=\mathrm{Me}, \mathrm{Ph}$

316 Phenanthrenes

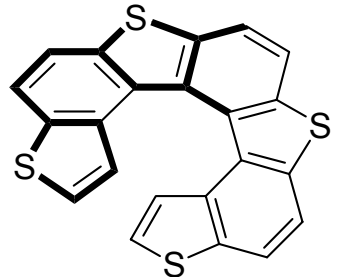

319 Hetero[7]helicene

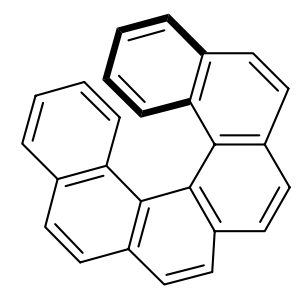

317 [6]Helicene

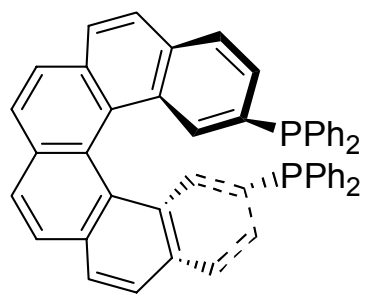

318 Helical-Chiral Ligand

Figure 6. Examples of phenanthrenes and helicenes.

\section{Research Objective}

Our research Group recently developed a new synthetic method for polycyclic aromatic hydrocarbons by employing the $\mathrm{C}^{2}-\mathrm{C}^{6}$ cyclization reaction of the benzannulated enyne-allenes. This procedure was successfully adopted for the synthesis of 4,5-diarylphenanthrenes $\mathbf{7 8}$ having a helical twist due to steric interactions. ${ }^{33}$ We were also interested in converting the two benzannulated 5-membered rings of $\mathbf{7 8}$ to 6 -membered rings via a ring expansion reaction. We envisioned that the ring expansion and aromatization could be achieved using Wagner-Meerwein rearrangement of the corresponding fluorenylmethanols. ${ }^{97}$ Scheme 69 displays a simple example with its reaction mechanism. 

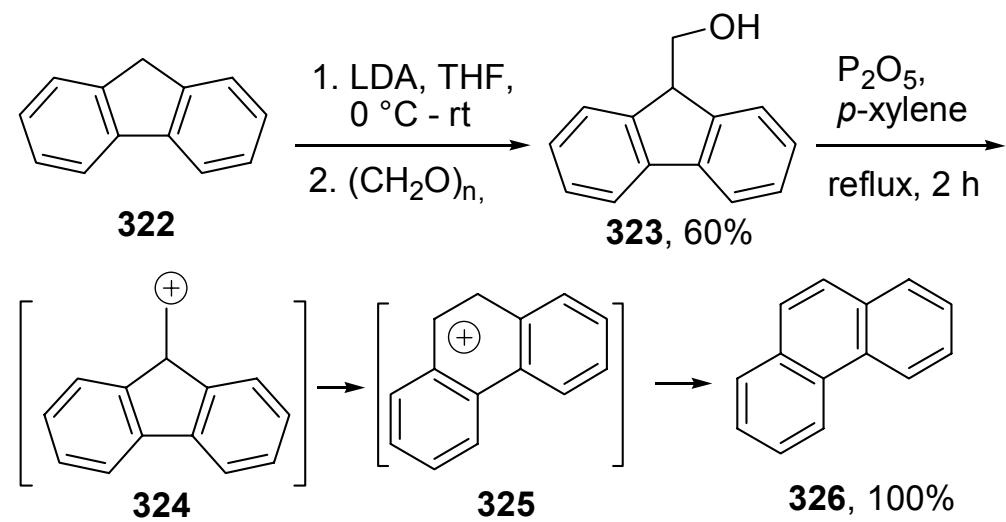

Scheme 69. Wagner-Meerwein rearrangement.

\section{Literature Survey for the Synthesis of Helical Compounds, Such as Phenanthrenes and}

\section{Helicenes etc.}

\subsection{Synthesis of Phenanthrenes and Related Compounds}

Several synthetic strategies for 4,5-dimethylphenanthrenes and related compounds have been reported, including ozonolysis of pyrene, ${ }^{98}$ intramolecular cyclization of 2,2'bis(halomethyl)-6,6'-dimethylbiphenyls by treatment with sodium amide in liquid ammonia, ${ }^{99}$ photochemically induced dehydrocyclization of corresponding stilbenes using $\mathrm{I}_{2} / \mathrm{O}_{2}$ as dehydrogenation agent, ${ }^{100}$ and desulfurization of phenanthrene derivatives formed by Diels-Alder reaction, containing two fused thiophene rings. ${ }^{101}$ Among these methods, photocyclization has been widely employed to synthesize a variety of phenanthrenes with different substituents. ${ }^{96 \mathrm{~d}, \mathrm{e}, 100,102}$ An example is shown in Scheme $70 .{ }^{100 \mathrm{~d}}$ The disadvantage of this method is that a highly dilute condition is required to obtain reasonable yield.

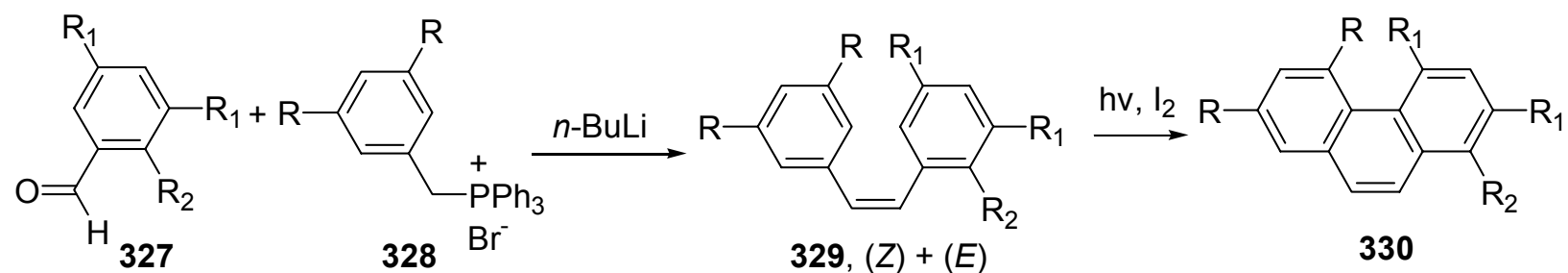

Scheme 70. Synthesis of phenanthrenes via photodehydrocyclization. 
Several new approaches to the skeletons of phenanthrene appeared recently, including radical cyclization, intramolecular or intermolecular aryne cycloaddition, and palladium catalyzed co-trimerization of benzyne with alkynes. ${ }^{103}$

\subsection{Synthesis of Helicenes and Related Compounds}

The classical and widely used method for synthesis of helicenes involved the oxidative photocyclization of stilbene-type precursors. ${ }^{88,90 \mathrm{~b}, \mathrm{c}, 104}$ This traditional method suffered from its fundamental drawbacks, such as highly dilute solution and low functional group tolerance. ${ }^{105}$

Several new methods were developed to provide useful alternatives for the synthesis of helicene type skeletons and for material applications. ${ }^{88 \mathrm{e}}$

Katz et al. first reported their pioneering work for the synthesis of racemic helicene bisquinones through the Diels-Alder reaction. ${ }^{105}$ Scheme 71 demonstrates the pathway leading to helical quinone 333 .<smiles>C=Cc1ccc(C=C)cc1</smiles>
331<smiles>O=C1C=CC(=O)C=C1</smiles>
332

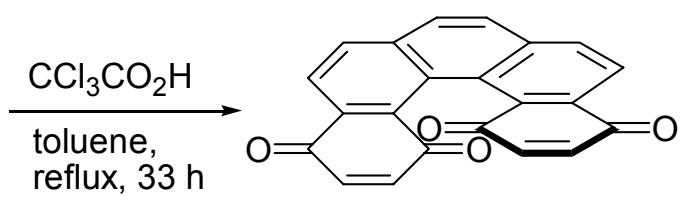

$333,17 \%$

Scheme 71. Katz's approach to helicene quinones via nonphotochemical route.

In 1999, Gingras et al. reported a five-step synthesis of [7]helicenes by using "carbenoid coupling" strategy. ${ }^{106}$ Scheme 72 outlines the step-wise transformations from biphenanthrol to [7]helicene 337.

Harrowven et al. reported a new route to [5]helicenes via a tin-mediated, nonreducing tandem radical cyclization. ${ }^{107}$ This short and simple protocol furnished a series of different substituted [5] helicenes in moderate yields. ${ }^{107 \mathrm{~b}}$ An example is described in Scheme 73. 


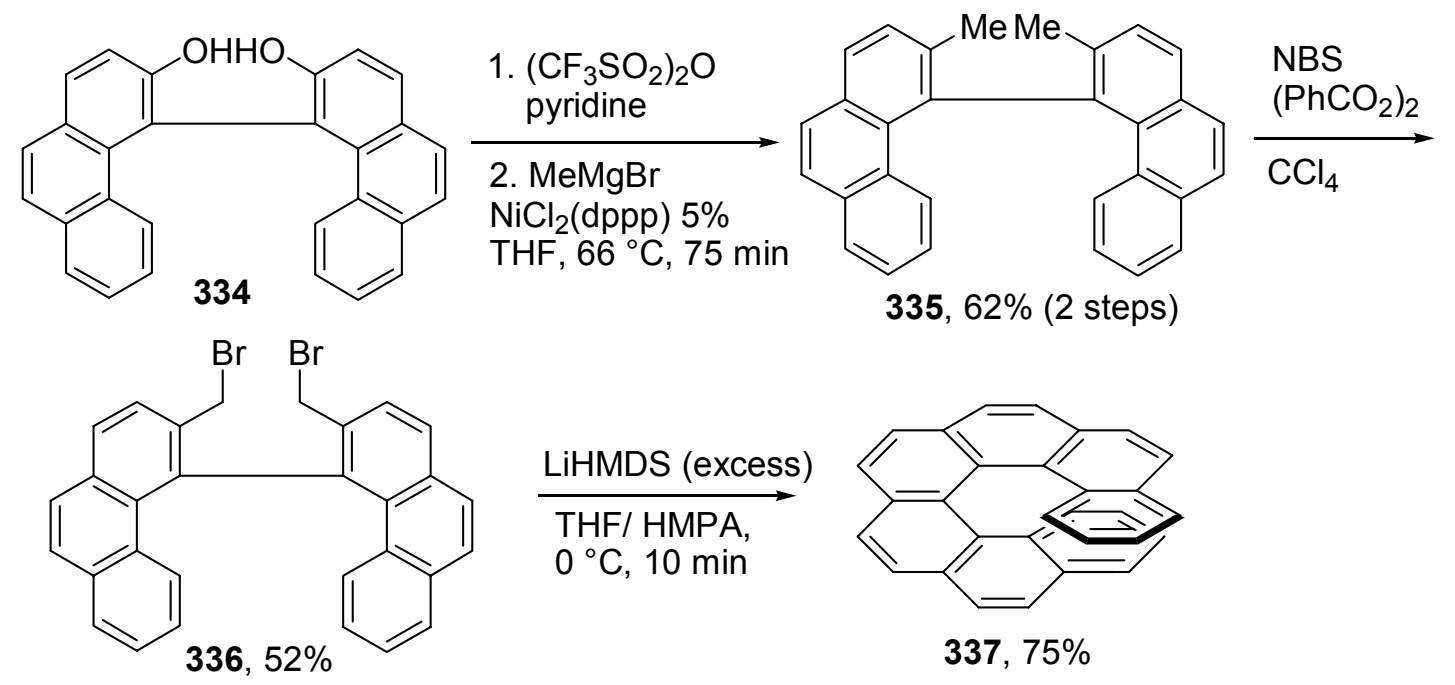

Scheme 72. Gingras's approach to a [7]helicene by carbenoid coupling.

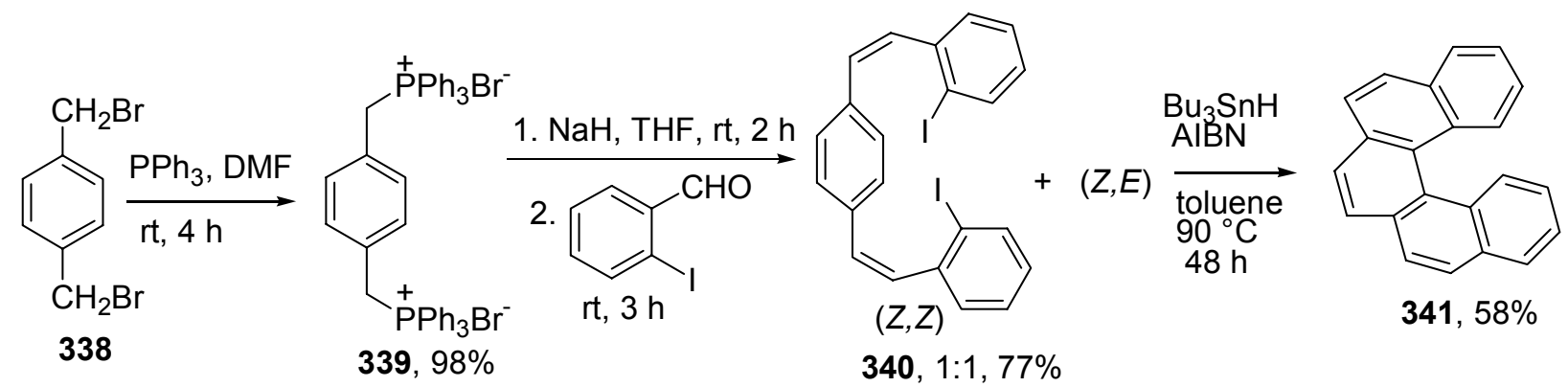

Scheme 73. Harrowven's approach to a [5]helicene via tandem radaical cyclization.

In 2002, Stará et al. reported a new paradigm for the nonphotochemical synthesis of tetrahydrohelicenes/helicenes based on a key intramolecular $[2+2+2]$ cycloisomerization of aromatic triynes/cis,cis-dienetriynes catalyzed by $\mathrm{Co}(\mathrm{I})$ or $\mathrm{Ni}(0) .{ }^{108}$ This protocol reflected the art of organic synthesis for exploiting the atom-economic isomerization. ${ }^{108 a}$ Different substituted [5], [6], and [7] helicenes were produced in good yields (60 to 83\%) under very mild conditions. Scheme 74 demonstrates an example of the key reaction.

The first double helicene having a pentahelicene and a heptahelicene was synthesized recently by Guitián et al. ${ }^{109}$ A new palladium-catalyzed cyclotrimerization of arynes was involved in this synthesis (Scheme 75). 


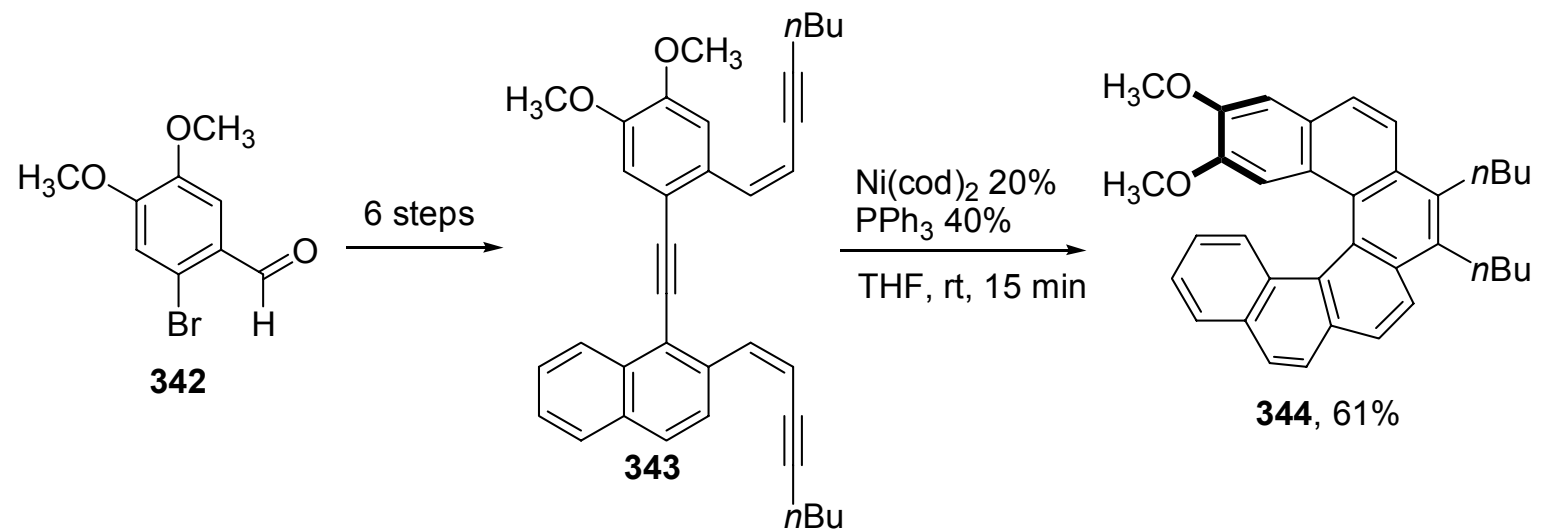

Scheme 74. Stara's approach to a [6]helicene via nickel(0)-catalyzed $[2+2+2]$ cycloisomerization.

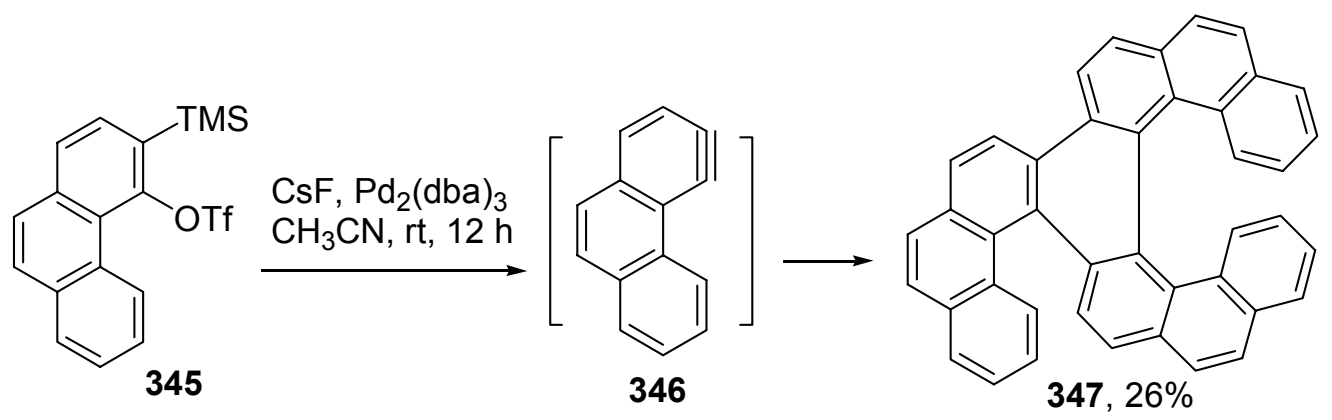

Scheme 75. Guitian's approach to a double helicene via $\operatorname{Pd}(0)$-catalyzed cyclotrimerization of aryne.

A major challenge in helicene chemistry is the development of efficient methods for synthesis of individual enantiomers with high enantioselectivity. ${ }^{88}$ The classic methods of obtaining helicenes in nonracemic form generally involved separation of the racemic mixture via HPLC using chiral column, ${ }^{90 b, c, 106 a, 110}$ or resolving agents. ${ }^{90 f, g, 111}$ Carreño reported the first enantioselective synthesis of 7,8-dihydro[5]helicenequinones via Diels-Alder reactions. ${ }^{112}$ Scheme 76 shows the synthetic route, and the dihydrohelicene quinones could be obtained with $>90 \%$ ee.

A different asymmetric approach to conjugated helicenes was developed by Karikomi et $a l{ }^{113}$ The chiral [5]helicenes $\mathbf{3 6 0}$ were synthesized by an aromatic oxy-cope rearrangement, followed by reduction, hydrolysis, dehydration, and aromatization (Scheme 77). 


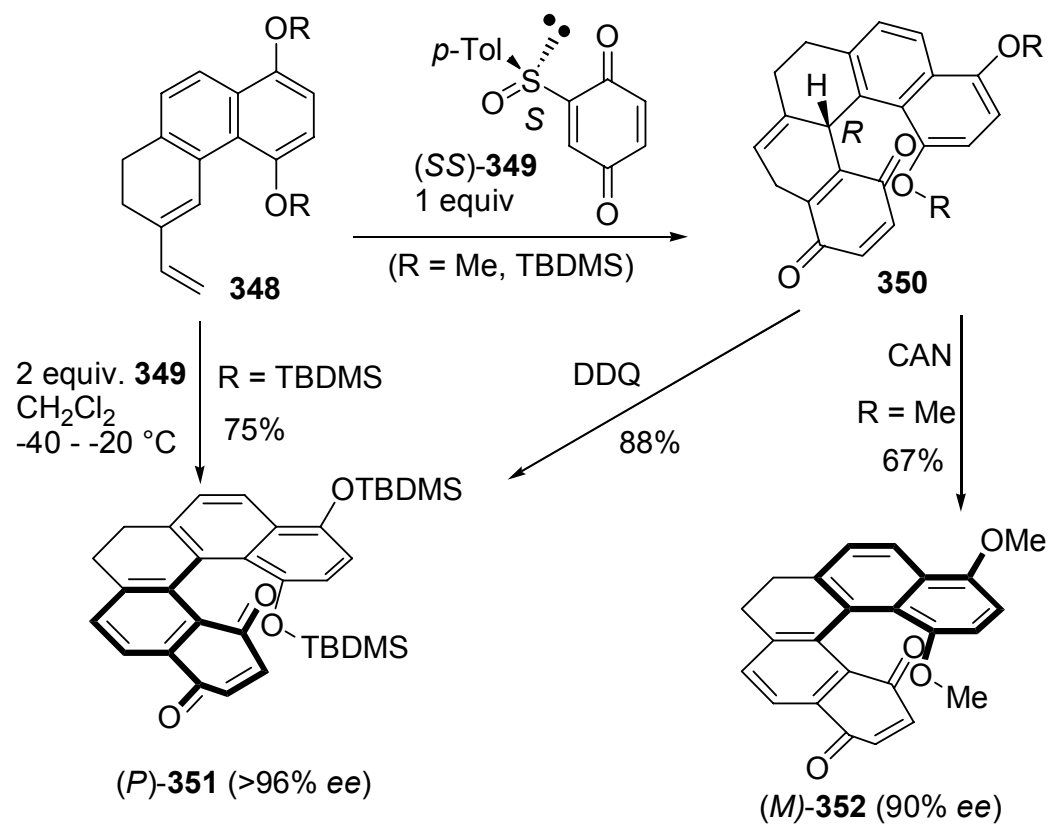

Scheme 76. Carreno's approach to enantiopure dihydro-[5]helicenequinones.

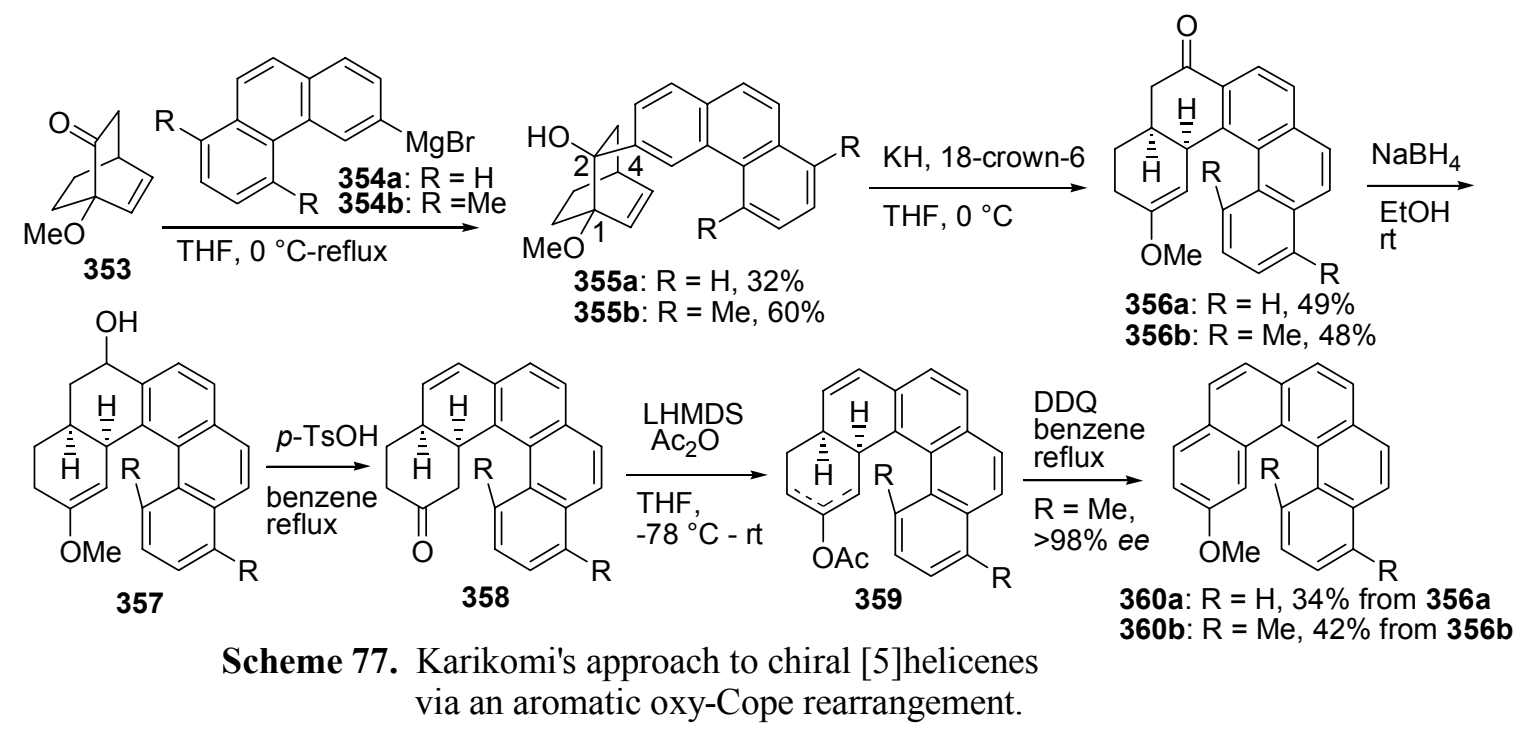

Synthesis of nonracemic [7]helicenes via Friedel-Crafts diacylation of phenanthrenes was reported by Katz et al. ${ }^{114 a}$ They also developed the method for functionalization of [6]- and [7]helicenes at their most sterically hindered positions. ${ }^{114 \mathrm{~b}}$

Some other helical compounds, such as oligothiophene, ${ }^{115}$ and angular [n]phenylene ${ }^{116}$ etc. were prepared by iteration, and cobalt-catalyzed double cycloisomerization respectively. Schemes 78 and 79 outline the synthetic sequences for these two new helical compounds. 


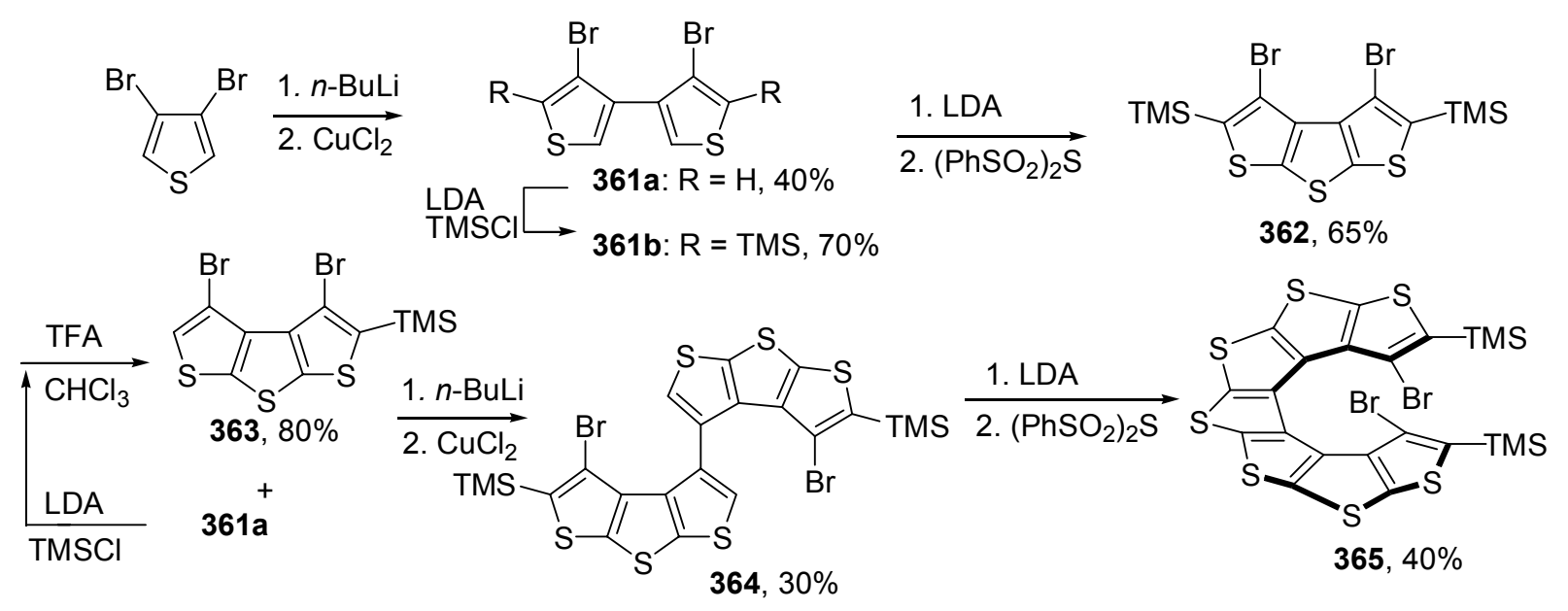

Scheme 78. Rajca's approach to a heptathiophene.
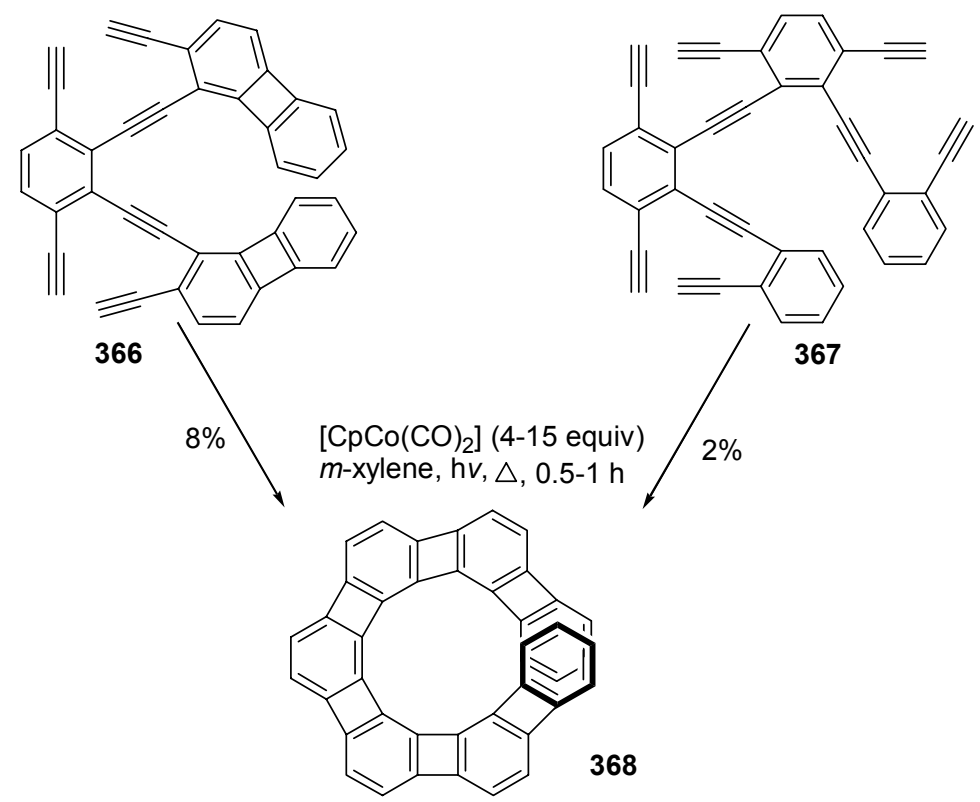

Scheme 79. Volhardt's approach to a [7]heliphene.

\section{Results and Discussion}

\subsection{Synthesis of Dibenz $[a, j]$ anthracene 371}

The synthetic sequence outlined in Scheme 80 involved deprotonation of the fluorenetype hydrogen of polycyclic hydrocarbon 369, first synthesized by Yanzhong Zhang, one of our research group members, with lithium diisopropylamide followed by aldol condensation with paraformaldehyde to afford the fluorenylmethanol $\mathbf{3 7 0}$ in $91 \%$ yield. ${ }^{117}$ On exposure to 
phosphorus pentoxide under refluxing $p$-xylene at $138{ }^{\circ} \mathrm{C}$ for $2 \mathrm{~h}$, the fluorenylmethanol 370 was transformed to the symmetric dibenz $[a, j]$ anthracene 371 in $88 \%$ yield. ${ }^{97}$<smiles>CC(C)(C)c1c2c(c(-c3ccccc3)c3ccccc13)-c1ccccc1C2</smiles>

369 $\underset{\text { THF, } 0{ }^{\circ} \mathrm{C}-\mathrm{rt}}{\stackrel{\text { LDA, }}{\left(\mathrm{CH}_{2} \mathrm{O}\right)_{\mathrm{n}}}}$

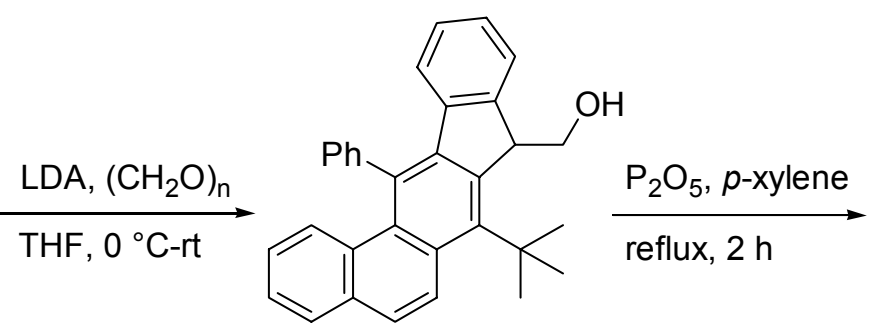

$370,91 \%$<smiles></smiles>

$371,88 \%$

Scheme 80. Ring expansion via Wagner-Meerwein rearrangement.

Conceivably, the transformation from $\mathbf{3 7 0}$ to $\mathbf{3 7 1}$ involved the initial formation of carbocation 372, followed by ring expansion via a carbocation rearrangement, and an aromatization by deprotonation to form 374 (Scheme 81). ${ }^{97 a}$ It was interesting that the tert-butyl group was cleaved from the aromatic ring via a reversal of the Friedel-Crafts alkylation reaction on exposure to proton or Lewis acids. ${ }^{118}$ This was observed previously and served as a useful group-directing method by occasionally introducing the tert-butyl group into an aromatic ring, in turn directing the placement of other substituents, and then removing the tert-butyl group.

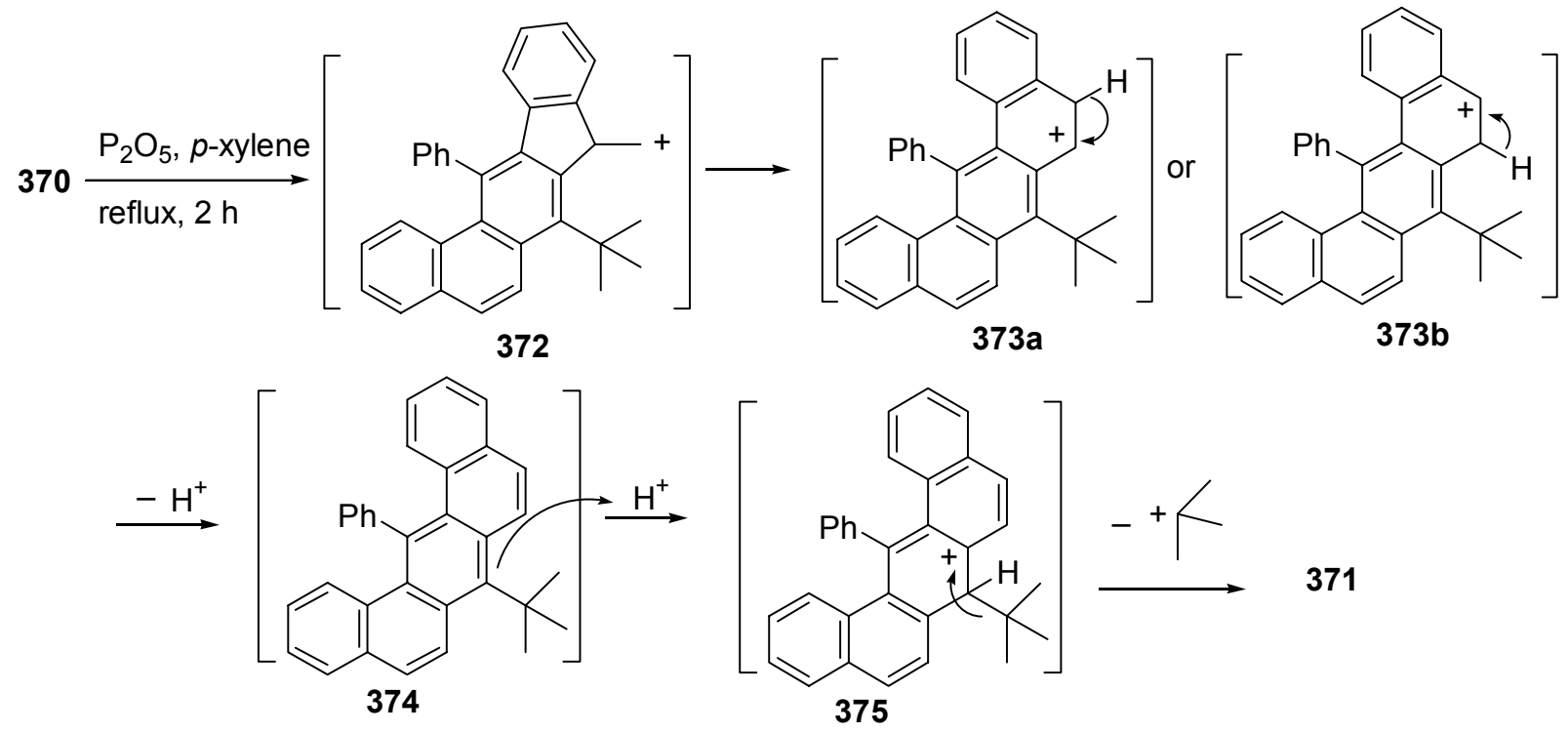

Scheme 81. Proposed mechanism leading to 371. 


\subsection{Synthesis of Helical Compound 377 and Polycyclic Compounds 378 and 379}

Based on the above simple model study in Scheme 80 , Scheme 82 demonstrates the transformation from 78a to three different polycyclic compounds. Similarly, the preparation of diol 376 from 78a involved deprotonation and condensation with paraformaldehyde to give $\mathbf{3 7 6}$ as a mixture of three isomers (isomer ratio $=22: 12: 1$ ) in good yield. On exposure to phosphorus pentoxide in $p$-xylene at variable temperature and reaction time, three polycyclic conpounds $\mathbf{3 7 7}$, 378, and 379 were isolated. If the reaction mixture was heated at $110{ }^{\circ} \mathrm{C}$ for 15 minutes, the helical 17,18-diphenyl-dibenzo[a,o]pentaphene $\mathbf{3 7 7}$ was produced. If the reaction mixture was heated under refluxing for $1.5 \mathrm{~h}$, the asymmetric compound $\mathbf{3 7 8}$ was produced. If the reaction mixture was heated under refluxing for $12 \mathrm{~h}$, the symmetric butterfly-shaped compound $\mathbf{3 7 9}$ was obtained. We also discovered that compounds $\mathbf{3 7 7}$ and $\mathbf{3 7 8}$ could convert to $\mathbf{3 7 9}$ just by changing reaction time. The formation of $\mathbf{3 7 8}$ and $\mathbf{3 7 9}$ was very unexpected.

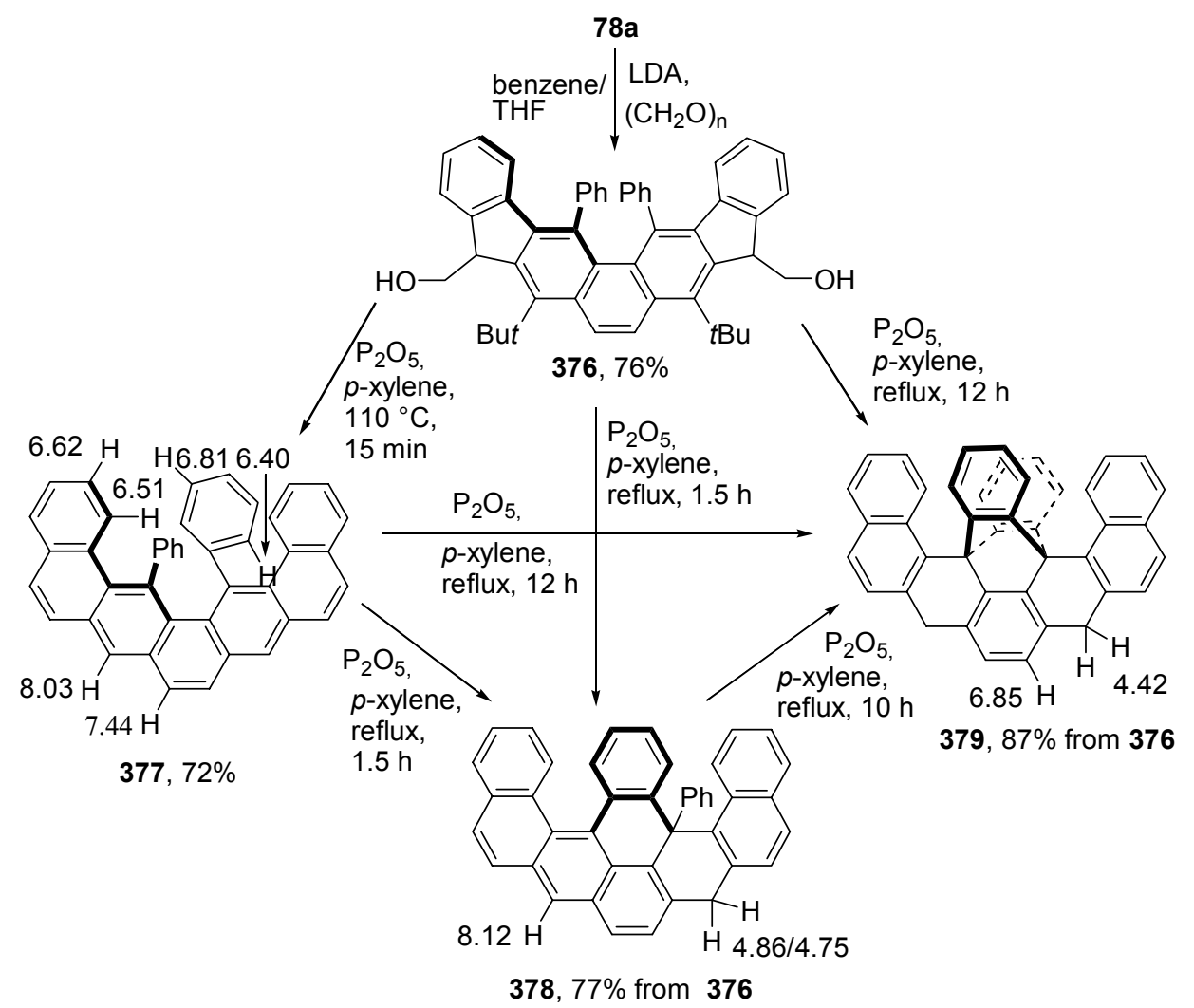

Scheme 82. Synthetic pathway leading to polycyclic compounds $\mathbf{3 7 7 , 3 7 8}$, and $\mathbf{3 7 9}$. 
The structures of compounds $\mathbf{3 7 7 - 3 7 9}$ were elucidated with high resolution mass spectroscopy and ${ }^{1} \mathrm{H}$ and ${ }^{13} \mathrm{C}$ NMR spectroscopy, also by the product of a subsequence reaction. The molecular ions with correct exact mass were detected. The ${ }^{1} \mathrm{H}$ NMR spectra showed the right numbers of signals and pattern of multiplicity consistent with the assigned structures. The partial chemical shift assignments for $\mathbf{3 7 7 , 3 7 8}$, and $\mathbf{3 7 9}$ are included in Scheme 82. Compound 377 as a symmetric aromatic compound exhibited two singlets at $\delta 8.03$ and 7.44 , respectively, attributable to the four aromatic hydrogens on the benzene rings with a phenyl substitutent and the central benzene ring. The upfield shift aromatic signals at $\delta 6.51$ and 6.62 , attributable to the two aromatic hydrogen atoms closest to the phenyl substituents, indicate that the phenyl substituents are oriented perpendicular to the main aromatic system.

It is interesting to note that the asymmetric nature of $\mathbf{3 7 8}$ was manifested with a set of signals from the diastereotopic methylene hydrogens on the six-membered ring. An AB pattern at $\delta 4.83$ and 4.77 with a large geminal coupling constant of $23.0 \mathrm{~Hz}$ was observed. However, compound $\mathbf{3 7 9}$ has several symmetrical elements, including two planes of symmetry and a $C_{2}$ symmetry, and exhibits very simple ${ }^{1} \mathrm{H}$ NMR signals, having 4 hydrogen atoms at $\delta 4.42$ as singlet, 2 hydrogen atoms at $\delta 6.85$ as singlet, and only eight hydrogen atoms for phenyl substituents. This indicates the phenyl substituents are no longer mono substituted. Instead, 1,2disubstituted benzene bridges are produced. The ${ }^{13} \mathrm{C}$ NMR spectrum of 379 showed two signals in the aliphatic region for the $\mathrm{sp}^{3}$ carbons. On exposure of compound 379 to DDQ under refluxing benzene, diketone $\mathbf{3 8 0}$ was produced (eq 3). The structure of diketone $\mathbf{3 8 0}$ was established by X-ray structure analysis. The reaction mechanism to account for the formation of 379 is outlined in Scheme 83. 


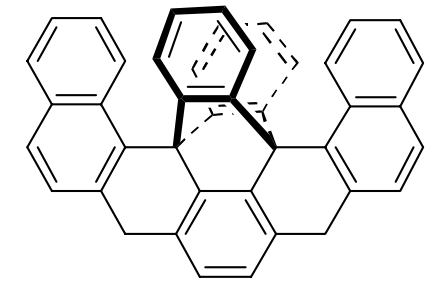

379 $\underset{\text { reflux, } 72 \mathrm{~h}}{\stackrel{\mathrm{DDQ}}{\longrightarrow}}$

(1)
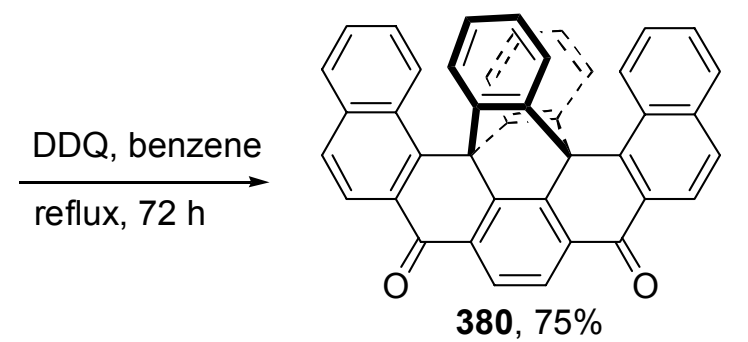

eq 3
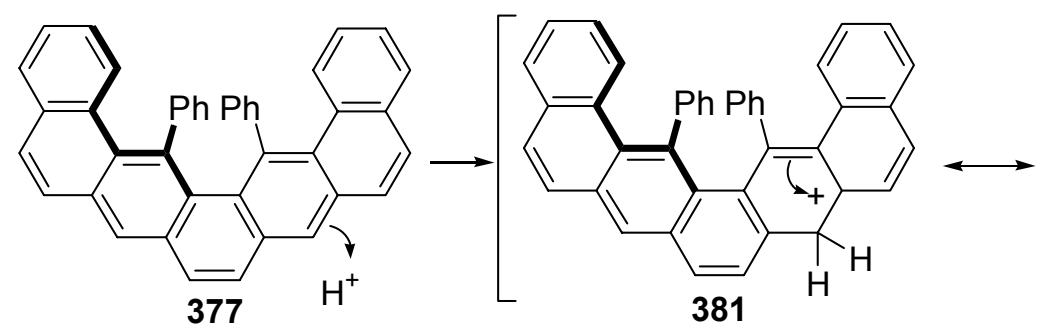

381

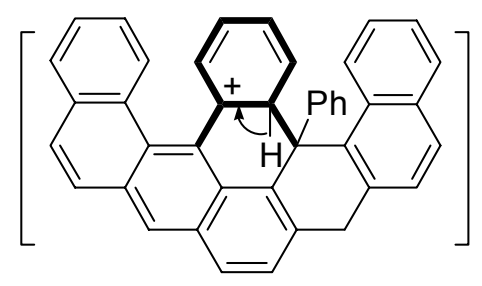

383
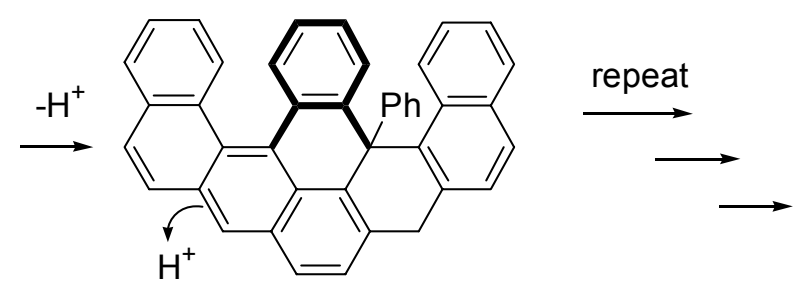

379

Scheme 83. Proposed mechanism leading to $\mathbf{3 7 8}$ and 379.

The transformation from diol $\mathbf{3 7 6}$ to $\mathbf{3 7 8}$ and $\mathbf{3 7 9}$ occurred with an initial Wagner-

-Meerwein rearrangement and a reversal of the Friedel-Crafts alkylation reaction to form 377.

Subsequent intramolecular Friedel-Crafts arylation involved one of the benzene rings having the

phenyl substituent. Initially, one of the double bonds was protonated to form the carbocation 381/382. The other pendant phenyl substituent was close enough to attack $\mathbf{3 8 2}$ to form $\mathbf{3 8 3}$, which then underwent deprotonation to furnish 378. A repeat of the Friedel-Crafts arylation reaction of $\mathbf{3 7 8}$ led to the symmetric compound $\mathbf{3 7 9}$.

The 4,5-di(4-biphenylyl)phenanthrene $\mathbf{7 8 b}$ was also selected for condensation with paraformaldehyde leading to diol 385a in 77\% yield as a mixture of two isomers (isomer ratio = 1:1.2). In this case, one of the minor isomers as presenting in diol $\mathbf{3 7 6}$ was not detected in the crude reaction mixture by ${ }^{1} \mathrm{H}$ NMR. The diol 385a was converted to helical compound 386a 
and compound $\mathbf{3 8 7}$ having a $C_{2}$ symmetry, involving Wagner-Meerwein rearrangement and intramolecular Friedel-Crafts arylation (Scheme 84). In 387, an AB pattern at $\delta 4.46$ and 4.43 with a large geminal coupling constant of $21.9 \mathrm{~Hz}$ was observed on a $600 \mathrm{MHz} \mathrm{NMR}$ spectrometer. However, the use of diol 385b produced from the newly synthesized 4,5-di(1naphthyl)phenanthrene $\mathbf{3 8 4} 4^{119}$ under similar conditions only led to the helical compound $\mathbf{3 8 6 b}$ as a mixture of three isomers (isomer ratio $=7: 2: 1$ ). This is attributed to the asymmetric 1-naphthyl substituents oriented in syn, and anti fashion. In the case of anti isomers, two sets of NMR signals were observed due to the possibilities of two different orientations of the 1-naphthyl substituents. It was originally anticipated that the formation of the butterfly-shaped compound with a $C_{2}$ symmetry could occur. However, molecular modeling suggests that this pathway suffers from nonbonded steric interactions between the naphthyl group and the peripheral benzene rings. The ${ }^{1} \mathrm{H}$ NMR spectrum of the crude reaction mixture showed only broad peaks in the aromatic region, indicating that the starting diol $\mathbf{3 8 5} \mathbf{b}$ decomposed or polymerized.

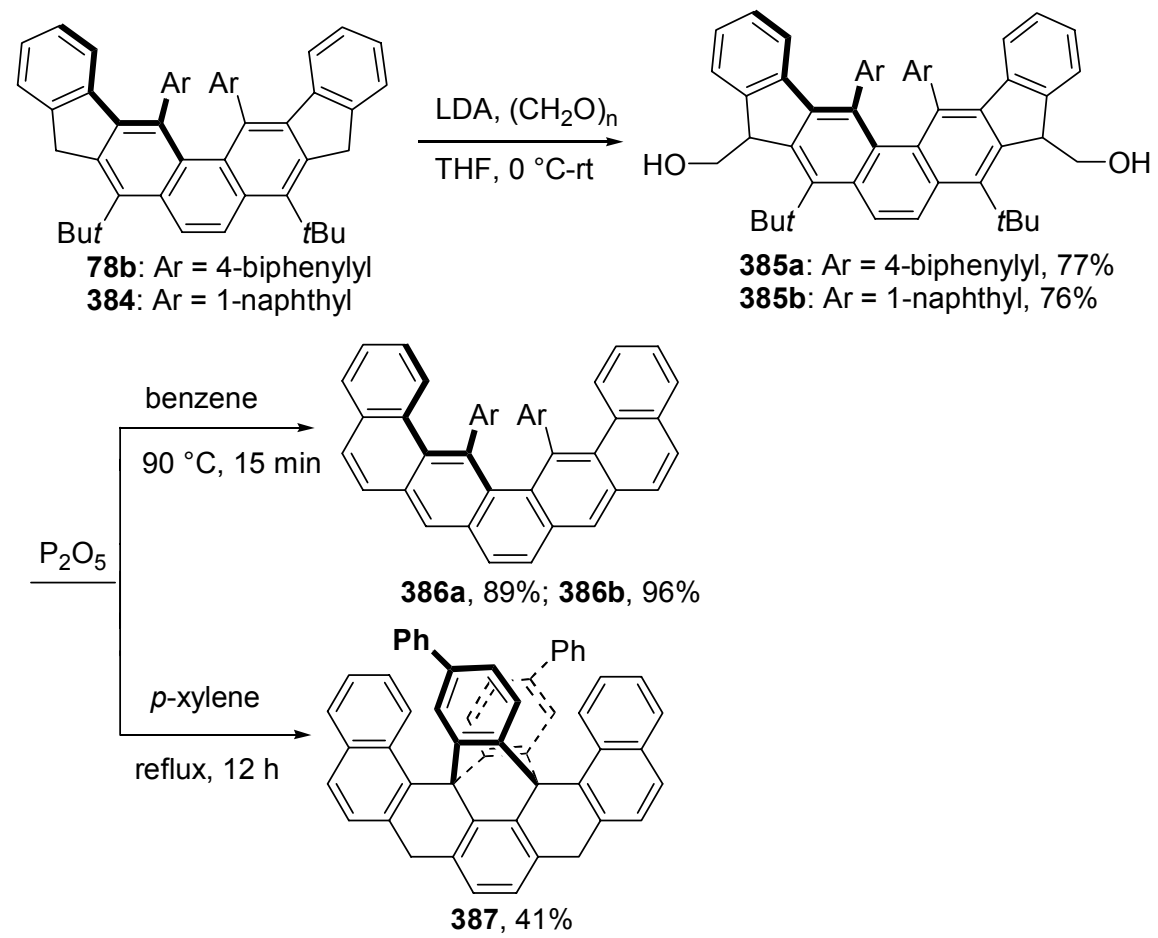

Scheme 84. Synthesis of polycyclic compounds $\mathbf{3 8 6}$ and $\mathbf{3 8 7}$. 


\subsection{Synthesis of 4,5-Di(1-naphthyl)phenanthrene 384 and the Linear Isomer 392}

The synthetic sequence for 384, depicted in Scheme 84, is outlined in Scheme 85 . Lithiation of the diacetylene $\mathbf{3 8 8}$ with $n$-butyllithium followed by condensation with diketone 389 afforded the propargylic diol $\mathbf{3 9 0}$ as an essentially 1:1 mixture of diastereomers in excellent yield. ${ }^{33}$ Treatment of $\mathbf{3 9 0}$ with triethylsilane in the presence of trifluoroacetic acid furnished the tetraacetylenic hydrocarbon 391 in excellent yield also essentially as a 1:1 mixture of diastereomers. On exposure to potassium tert-butoxide under refluxing toluene for $4 \mathrm{~h}$, the hydrocarbon 391 was transformed to the 4,5-di(1-naphthyl)phenanthrene $\mathbf{3 8 4}$ as a mixture of three diastereomers (isomer ratio $=4.1: 1.7: 1$ ), the linear isomer 392, along with ca. $1 \%$ of $\mathbf{3 9 3}$ detected in the crude reaction mixture before purification by ${ }^{1} \mathrm{H}$ NMR.

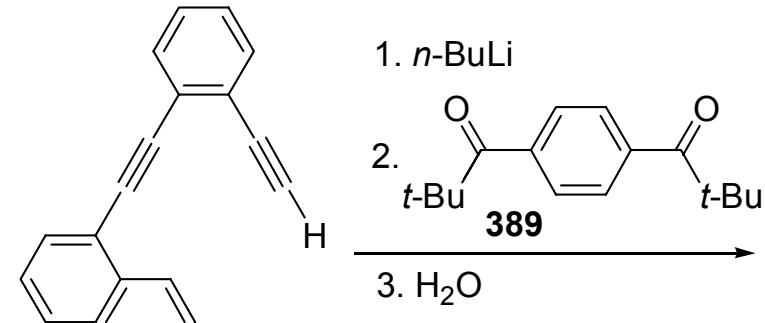

388

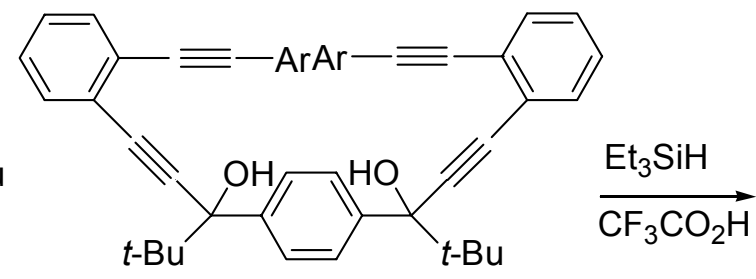

390: $\mathrm{Ar}=1$-naphthyl, $99 \%$

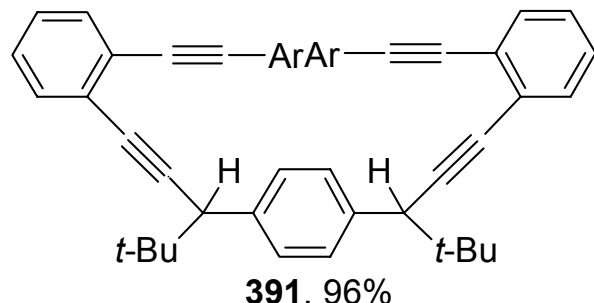

$391,96 \%$

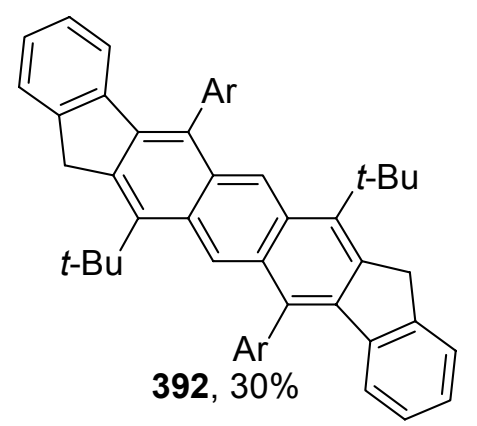

\section{$\mathrm{KOt}-\mathrm{Bu} / \mathrm{t}-\mathrm{BuOH}$}

refluxing toluene, $4 \mathrm{~h}$

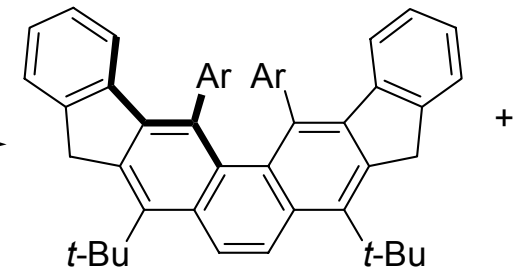

$384,52 \%$

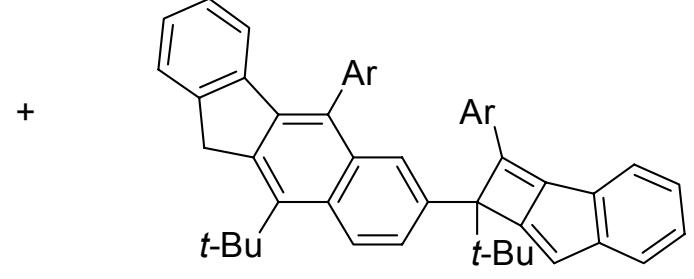

$393,1 \%$

Scheme 85. Synthesis of 4,5-di(1-naphthyl)phenanthrenes via benzannulated enyne-allenes. 
Conceivably, the transformation from 391 to $\mathbf{3 8 4}$ involved an initial prototropic isomerizatiom to form the benzannulated enyne-allenes 394 (Scheme 86). A subsequent $C^{2}-C^{6}$ cyclization generated the biradical 395, which in turn underwent an intramolecular radical-radical coupling to give 396. Although the transformation from 394 to 396 could also be regarded as a Diels-Alder reaction, mechanistic and DNA-cleavage studies of analogous systems supported a two-step biradical pathway. ${ }^{29 a, g, 30 a}$ A second formal Diels-Alder reaction of 396 produced 398 which gave 4,5-di(1-naphthyl)phenan-threne 384 after two subsequent tautomerizations. The similar transformation from $\mathbf{3 9 1}$ to $\mathbf{3 8 4}$ was observed in the previous case. ${ }^{33}$ The regioselectivity for the $\alpha$ carbon could attribute to the higher reactivity of the $\alpha$ - than that of $\beta$-position of naphthalene in homolytic addition.

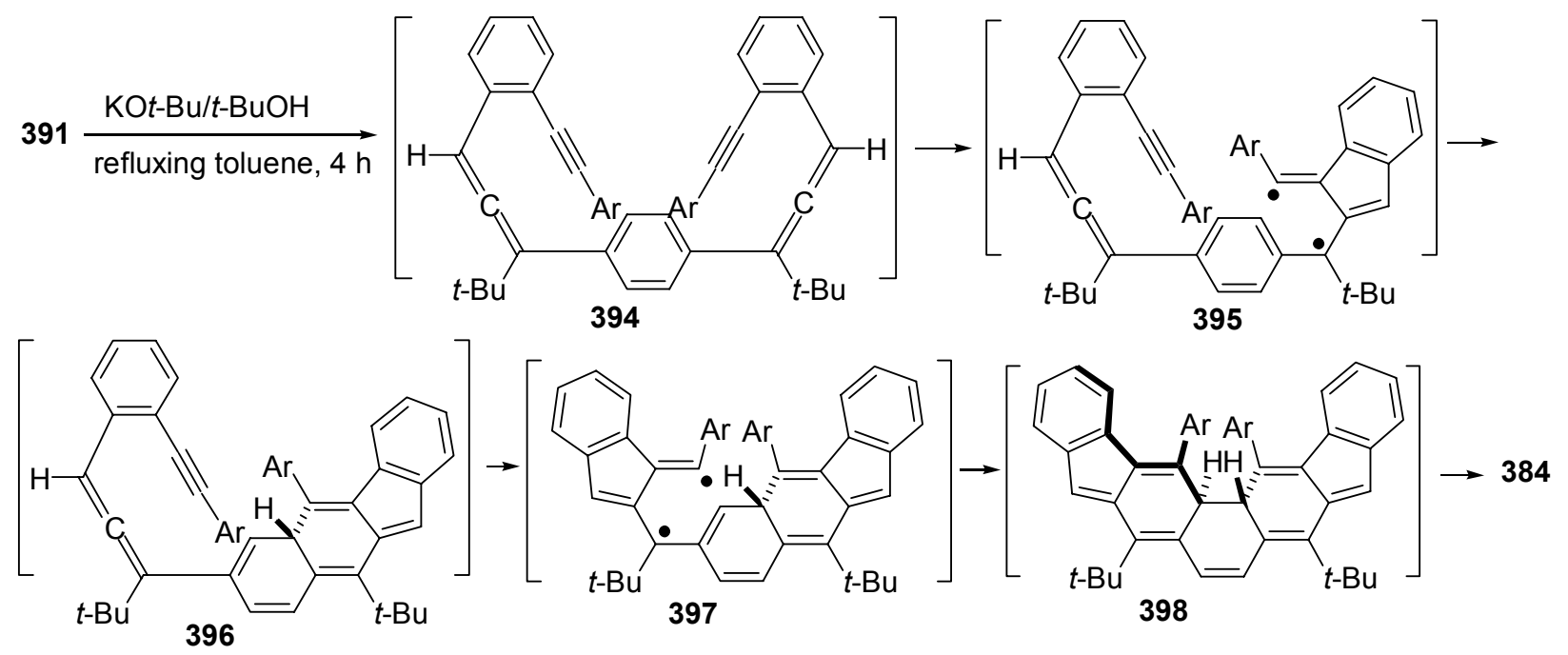

Scheme 86. Proposed mechanism leading to 384 .

The formation of $\mathbf{3 9 2}$ indicates that the rate of transformation from 396 to 398 is competitive with that of the tautomerization of 396 to 399 (Scheme 87). A rapid initial tautomerization could lead to the formation of $\mathbf{3 9 9}$, followed by $\mathrm{C}^{2}-\mathrm{C}^{6}$ cyclization generating biradical 400. Subsequent radical-radical coupling and tautomerization could lead to the linearly fused isomer $\mathbf{3 9 2}$ as a result of reducing nonbonded steric interactions in the step of the 
intramolecular radical-radical coupling. The formation of the linearly fused isomer from this pathway was not observed previously. ${ }^{33}$ Presumably, the nonbonded steric interactions are more severe in $\mathbf{3 8 4}$ as compared to those in $\mathbf{7 8 .}$

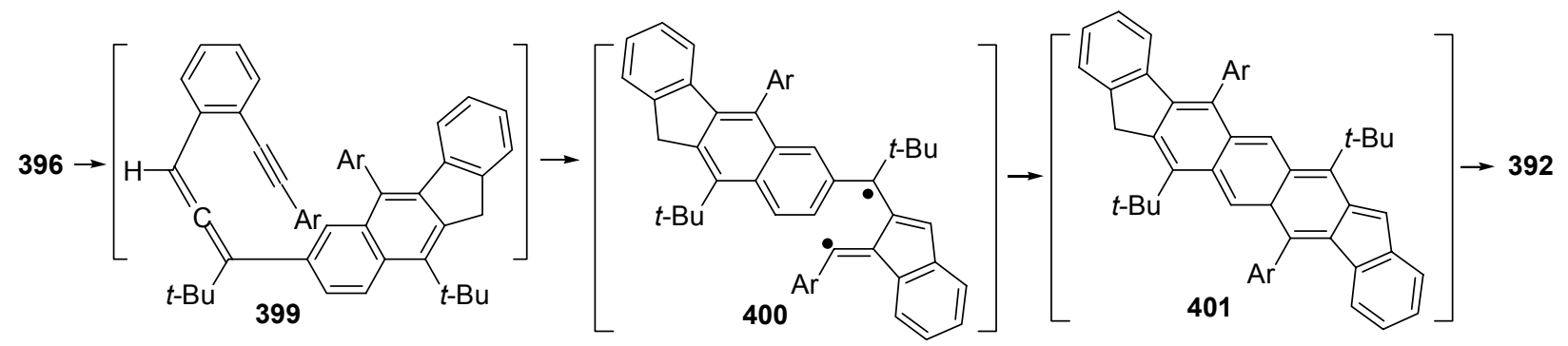

Scheme 87. Proposed mechanism leading to 392.

The formation of $\mathbf{3 9 3}$ involved the direct coupling of the radical center depicted in $\mathbf{3 9 7}$ leading to $[2+2]$ cycloaddition adduct having a $1 H$-cyclobut $[a]$ indene moiety. Similar examples of the intramolecular $[2+2]$ cycloaddition reaction of the benzannulated enyne-allene systems leading to $1 H$-cyclobut $[a]$ indenes were observed and reported previously. ${ }^{35 a, 32 b}$

The structure of the major isomer of $\mathbf{3 8 4}$ was unequivocally established by the X-ray structure analysis. The ORTEP drawing of major isomer of $\mathbf{3 8 4}$ is given in Figure 7. As expected, the two naphthyl substituents are bent away from each other and are essentially perpendicular to the diindino-fused phenanthrene ring system. In addition, the two 1-naphthyl substituents are oriented essentially parallel to each other and are pointing in the same direction in the case of the syn isomer. Because of the presence of a helical twist in the diindino-fused phenanthrene system and slow rotations of the naphthyl groups, two diastereomers are possible for the anti isomers with the two 1-naphthyl rings pointing toward opposite direction. 


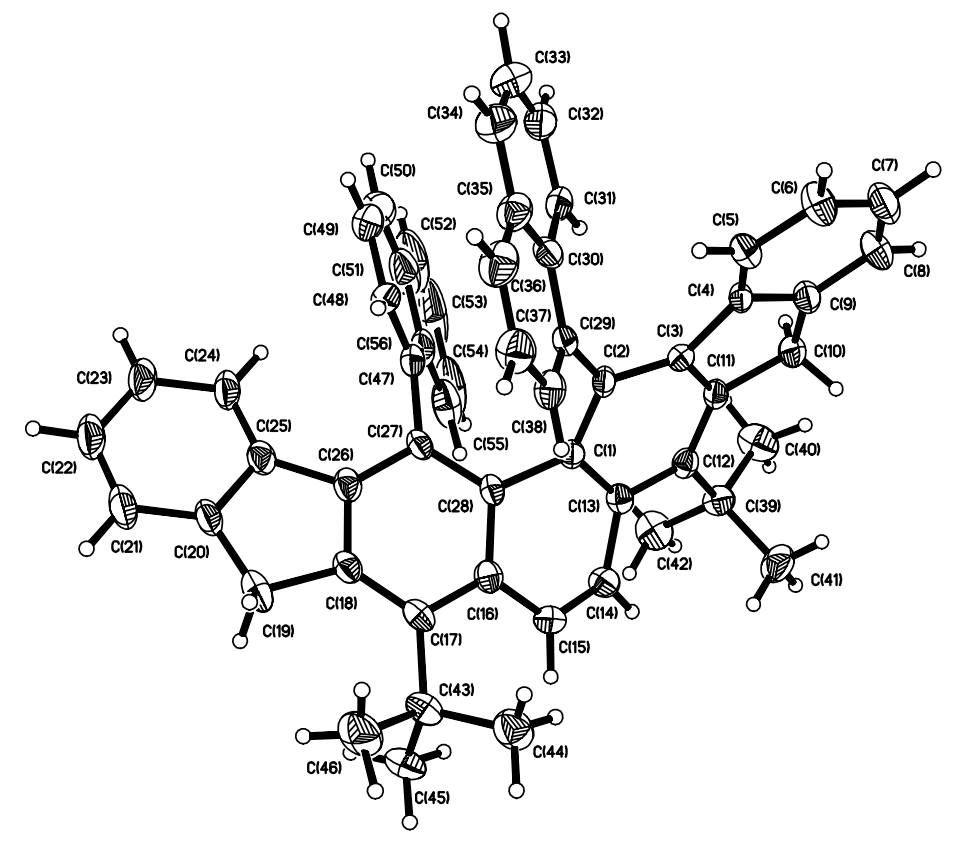

Figure 7. ORTEP drawing of the crystal structure of the syn isomer of $\mathbf{3 8 4}$.

\subsection{Synthsis of Diacetylene 388}

The diacetylene $\mathbf{3 8 8}$ used for the preparation of $\mathbf{3 8 4}$ in Scheme 85 was prepared from 1bromo-2-iodobenzene via two consecutive Sonogashira coupling reactions with 1ethynylnaphthalene and (trimethylsilyl)acetylene followed by desilylation as described previously (Scheme 88). ${ }^{33}$ The second coupling reaction was significantly improved in yield and reaction conditions by converting bromide 402 to iodide 403 .

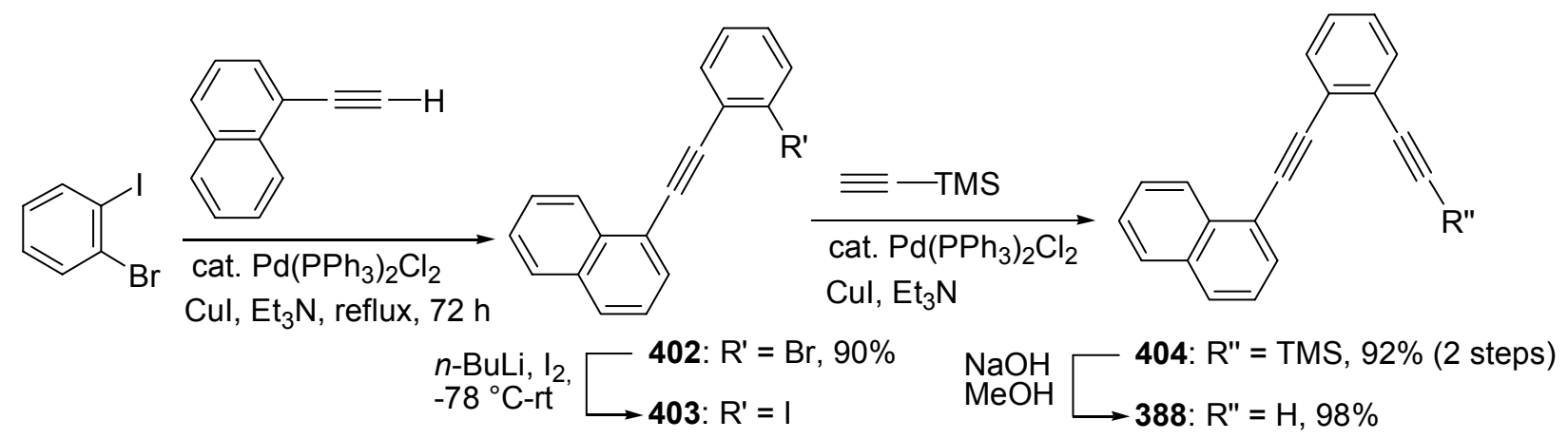

Scheme 88. Synthesis of a new diacetylene 388 . 


\subsection{Cyclization versus Ring Expansion}

Scheme 89 illustrates the competitive reaction between cyclization and ring expansion. Treatment of compound 405, ${ }^{120}$ prepared from benzophenone and diacetylene $\mathbf{6 0}$, with LDA and paraformaldehyde gave 406 in $86 \%$ yield. On exposure to phosphorous pentoxide under refluxing $p$-xylene for $2 \mathrm{~h}$, compound $\mathbf{4 0 7}$ and $\mathbf{4 0 8}$ were isolated in 5:4 ratio. Transformation from 406 to 407 involved an intramolecular Friedel-Crafts alkylation reaction. Compound 408 was produced via a Wagner-Meerwein rearrangement of $\mathbf{4 0 6}$ followed by an aromatization. In the cases with tert-butyl substituent, ring expansion products were obtained as the predominant products.
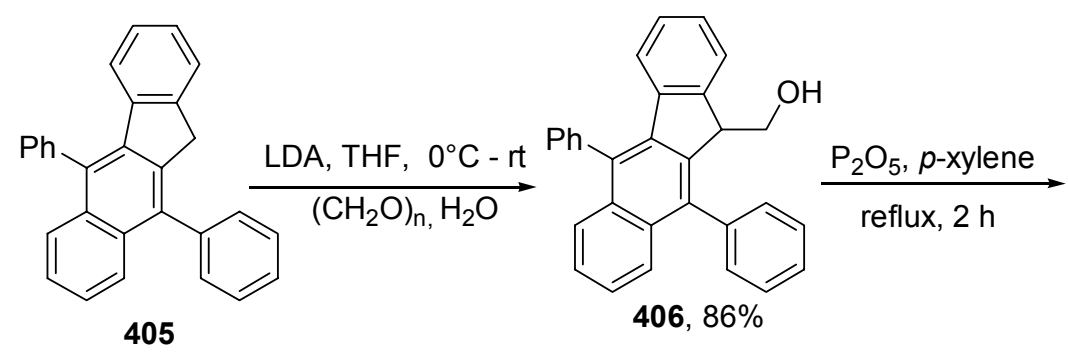

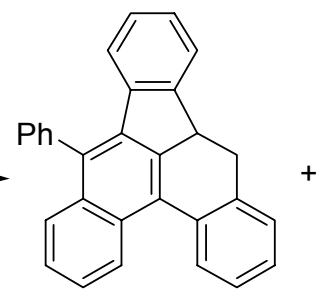

407, $54 \%$

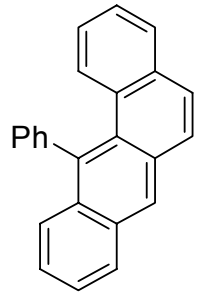

408, $40 \%$

Scheme 89. Cyclization versus ring expansion.

\section{Conclusions}

The Wagner-Meerwein rearrangement of fluorenylmethanols derived from 15,16-diaryldiindeno[2,1-b:1',2'-h]phenanthrenes (4,5-diarylphenanthrenes) was successfully adopted for the synthesis of helical 17,18-diaryl-dibenzo[a,o]pentaphenes involving the carbocation-promoted ring expansion and aromatization. Two of the 17,18-diaryl-dibenzo[a,o]pentaphenes were employed for the subsequent intramolecular Friedel-Crafts arylation reactions involving phenyl or 4-biphenylyl substiuents at the $17 \& 18$ positions, producing several butterfly-shaped compounds having two planes of symmetry and a $C_{2}$ symmetry in the case of the phenyl substituent and having only a $C_{2}$ symmetry in the case of the 4-biphenylyl substituent. They 
possess very interesting structural features. This methodology exhibits great potential for the synthesis of novel polycyclic aromatic compounds with a helical twist or with a deep valley.

A new and sterically more hindered 4,5-di(1-naphthyl)phenanthrene 384, which could exist as three rotamers and the first linear polycyclic compound 392 were also prepared involving a $\mathrm{C}^{2}-\mathrm{C}^{6}$ cyclization reaction followed by a radical-radical coupling reaction of the benzannulated enyne-allene. 


\section{CHAPTER V}

\section{Experimental Section}

All reactions were conducted in oven-dried $\left(120{ }^{\circ} \mathrm{C}\right)$ glassware under a nitrogen atmosphere except in the cases for the synthesis of diketones. Diethyl ether $\left(\operatorname{Et}_{2} \mathrm{O}\right)$ and tetrahydrofuran (THF) were distilled from benzophenone ketyl prior to use. Methylene chloride, benzene, toluene, and $p$-xylene were distilled over calcium hydride $\left(\mathrm{CaH}_{2}\right)$ prior to use. Silica gel for flash column chromatography was purchased from chemical suppliers. Melting points were

uncorrected. ${ }^{1} \mathrm{H}(270 \mathrm{MHz}, 600 \mathrm{MHz})$ and ${ }^{13} \mathrm{C}(67.9 \mathrm{MHz})$ NMR spectra were recorded in $\mathrm{CDCl}_{3}$ using $\mathrm{CHCl}_{3}\left({ }^{1} \mathrm{H} \delta\right.$ 7.26) and $\mathrm{CDCl}_{3}\left({ }^{13} \mathrm{C} \delta 77.00\right)$ as internal standards. IR spectra were taken on Perkin-Elmer 1600 FT-IR spectrometer. Mass spectra and high resolution mass spectra were obtained on Hewlett Packard 5970B GC/MSD instrument at $70 \mathrm{eV}$, VG 7070 by DEI, VG-ZAB by FAB, and DE-STR by MALDI.

$n$-Butyllithium $(2.5 \mathrm{M})$ in hexanes, tert-butyllithium $(1.7 \mathrm{M})$ in pentane, lithium diisopropylamide (LDA) $(2.0 \mathrm{M})$ in heptane/tetrahydrofuran/ethylbenzene, potassium tertbutoxide (1.0 M) in 2-methyl-2-propanol, 4-octyne, 1,4-dichloro-2-butyne, benzil, dimethyl 1,3acetonedicarboxylate, anthranilic acid, thionyl chloride, pyridine, $\mathrm{Pd}\left(\mathrm{PPh}_{3}\right)_{2} \mathrm{Cl}_{2}$, copper(I) iodide, triethylamine, phenylacetylene, (trimethylsilyl)acetylene, 1-bromo-2-iodobenzene, tributyltin hydride, 2,2'-azobisisobutyronitrile (AIBN), isoamyl nitrite, and 1,2-dichloroethane, mesitylene, triethylsilane, trifluoroacetic acid, 1,4-cyclohexadiene, 9-fluorenone, acetic anhydride, tetrakis(triphenylphosphine)-palladium $\left(\mathrm{Pd}\left(\mathrm{PPh}_{3}\right)_{4}\right)$, samarium (II) iodide $(0.1 \mathrm{M})$ in tetrahydrofuran, 2propanol, trifluoromethanesulfonic anhydride, $N, N$-diisopropylethylamine, diisopropylamine, tert-butyldimethylsilyl chloride $(1.0 \mathrm{M})$ in THF (TBDMSCl), hexamethylphosphoramide (HMPA), anhydrous aluminum chloride, benzophenone (277), benzosuberone (278), 2,2- 
dimethylpropiophenone (292), 1-indanone, 1-tetralone, iodomethane, and 4H-cyclopenta[def]phenanthrene, ${ }^{82}$ sodium hydride, sodium azide, lead (IV) acetate, boron trifluoride diethyl etherate, methyl formate, trimethyl orthoformate, perchloric acid, paraformaldehyde, phosphorus pentoxide, 2-naphthoyl chloride, terephthaloyl chloride, $\mathrm{CuBr} \cdot \mathrm{SMe}_{2}$, 2,3-dichloro-5,6-dicyano1,4-benzoquinone (DDQ), 1-ethynylnaphthalene, and iodine were purchased from chemical suppliers and were used as received without further purification.

2,5-Dicarbomethoxy-3,4-diphenylcyclopentadienone (162) was prepared from dimethyl 1,3-acetonedicarboxylate and benzil according to the reported procedure. ${ }^{53}$ 1-(2-Ethynylphenyl)2-phenylethyne as the precursor of $\mathbf{6 0}$ was prepared as described previously from 1-bromo-2iodobenzene, (trimethylsilyl)acetylene, and phenylacetylene. ${ }^{33}$ Diester 183 was prepared in $96 \%$ yield from condensation between $\mathbf{1 6 2}$ and benzyne as reported previously. ${ }^{55} 4 \mathrm{H}$ Cyclopenta[def]-phenanthren-4-one $(\mathbf{2 7 5})^{81}$ and 8,9-dihydrocyclopenta[def]phenan-thren-4-one (276) $^{59,84}$ were prepared from $4 H$-cyclopenta[def]phenanthrene as reported previously. 1-Oxo2,2-dimethyl-1,2,3,4-tetrahydronaphthalene $(\mathbf{2 9 8})^{86}$ and 2,2-dimethyl-1-indanone (299) ${ }^{87}$ were prepared from 1-tetralone and 1-indanone, respectively, according to the reported procedures. Tosyl azide was prepared from $p$-toluenesulfonyl chloride and sodium azide as reported previously. ${ }^{78 a} 369$ was synthesized by Yanzhong Zhang recently from tert-butyl 2-naphthyl ketone which was prepared from 2-naphthoyl chloride according to the reported procedure. ${ }^{121}$ The same procedures were repeated to make a large amount of 369. 4,5-Diarylphenanthrenes 78a and $\mathbf{7 8 b}$ were prepared from diketone $\mathbf{3 8 9}$ derived from terephthaloyl chloride as reported previously. ${ }^{121,33}$

Diester 163. A mixture of $0.174 \mathrm{~g}(0.500 \mathrm{mmol})$ of 2,5-dicarbomethoxy-3,4-diphenylcyclopentadienone $(\mathbf{1 6 2})^{53}$ and $0.10 \mathrm{~mL}(0.68 \mathrm{mmol})$ of 4-octyne in $3 \mathrm{~mL}$ of mesitylene in a sealed 
tube was heated to $190{ }^{\circ} \mathrm{C}$ for $12 \mathrm{~h}$. The solvent was removed in vacuo. Flash column chromatography (silica gel/10\% ethyl acetate in hexanes) afforded $0.109 \mathrm{~g}$ of 163 (0.253 mmol, 50\%) as a wax-like white solid: $\mathrm{mp} 105-108^{\circ} \mathrm{C}$; IR 1728, 1200, $702 \mathrm{~cm}^{-1} ;{ }^{1} \mathrm{H} \delta 7.13-7.06(6 \mathrm{H}$, m), 7.03-6.96 (4 H, m), $3.43(6 \mathrm{H}, \mathrm{s}), 2.62(4 \mathrm{H}, \mathrm{t}, J=8.3 \mathrm{~Hz}), 1.65(4 \mathrm{H}$, sextet, $J=7.7 \mathrm{~Hz})$, $1.02(6 \mathrm{H}, \mathrm{t}, J=7.3 \mathrm{~Hz}) ;{ }^{13} \mathrm{C} \delta 170.0,138.3,137.0,136.8,136.3,130.0,127.3,126.7,51.7,33.0$, 24.9, 14.9; MS $m / z 430\left(\mathrm{M}^{+}\right), 415,399,367,337$.

Diketone 164. To a flask containing $0.088 \mathrm{~g}(0.205 \mathrm{mmol})$ of 163 was added $4 \mathrm{~mL}$ of concentrated sulfuric acid. The mixture was swirled periodically until the solid was dissolved in the sulfuric acid at rt. After $3 \mathrm{~h}$, the reaction mixture was poured into an ice-water mixture and then was extracted with diethyl ether. The combined organic extracts were washed with water, dried over magnesium sulfate, and concentrated. Recrystallization of the crude yellow solid from $95 \%$ ethanol afforded $0.059 \mathrm{~g}$ of $164(0.161 \mathrm{mmol}, 79 \%)$ as bright-yellow crystals: $\mathrm{mp}$ $182-184{ }^{\circ} \mathrm{C}$; IR (KBr) 1700, 757, $721 \mathrm{~cm}^{-1} ;{ }^{1} \mathrm{H} \delta 8.09(2 \mathrm{H}, \mathrm{d}, J=7.7 \mathrm{~Hz}), 7.75(2 \mathrm{H}, \mathrm{d}, J=7.4$ Hz), $7.59(2 \mathrm{H}, \mathrm{td}, J=7.5,1.0 \mathrm{~Hz}), 7.38(2 \mathrm{H}, \mathrm{t}, J=7.4 \mathrm{~Hz}), 3.12(4 \mathrm{H}, \mathrm{t}, J=8.0 \mathrm{~Hz}), 1.55(4 \mathrm{H}$, sextet, $J=7.6 \mathrm{~Hz}), 1.10(6 \mathrm{H}, \mathrm{t}, J=7.3 \mathrm{~Hz}) ;{ }^{13} \mathrm{C} \delta 193.8,146.0,143.0,136.9,135.9,135.4$, 134.7, 129.1, 124.5, 123.5, 28.3, 24.4, 14.6; MS m/z $366\left(\mathrm{M}^{+}\right), 351,337$.

Diol 157a. To a solution of $0.18 \mathrm{~g}(0.89 \mathrm{mmol})$ of 1-(2-ethynylphenyl)-2-phenylethyne ${ }^{33}$ in 10 $\mathrm{mL}$ of diethyl ether under a nitrogen atmosphere at $0{ }^{\circ} \mathrm{C}$ was added $0.31 \mathrm{~mL}$ of a $2.5 \mathrm{M}$ solution of $n$-butyllithium $(0.78 \mathrm{mmol})$ in hexanes. The reaction mixture was then allowed to warm to $\mathrm{rt}$. After $30 \mathrm{~min}$ at $\mathrm{rt}$, a solution of $0.099 \mathrm{~g}(0.271 \mathrm{mmol})$ of 164 in $40 \mathrm{~mL}$ of diethyl ether was introduced via cannula. After an additional $2 \mathrm{~h}, 5 \mathrm{~mL}$ of water was introduced, and the reaction mixture was extracted with diethyl ether. The combined organic extracts were washed with brine and water, dried over sodium sulfate, and concentrated. Flash column chromatography 
(silica gel $/ 30 \%$ diethyl ether in hexanes) provided $0.197 \mathrm{~g}$ of $157 \mathrm{a}(0.256 \mathrm{mmol}, 94 \%$, a mixture of the trans and cis isomers, isomer ratio $=2: 1$ ) as a soil-colored solid: $\mathrm{mp} 107-113{ }^{\circ} \mathrm{C}$; IR 3528 , 3426, 2215, $753 \mathrm{~cm}^{-1}$; ${ }^{1} \mathrm{H} \delta 8.24(2 \mathrm{H}, \mathrm{d}, J=7.9 \mathrm{~Hz}), 7.85(2 \mathrm{H}, \mathrm{d}, J=7.4 \mathrm{~Hz}), 7.51-7.4(6 \mathrm{H}$, m), 7.4-7.09 (16 H, m), 3.32-3.13 (2 H, m), 3.13-2.98 (2 H, m), 2.48 (2 H, br), 1.92-1.76 (2 H, m), 1.76-1.52 (2 H, m), $1.03(6 \mathrm{H}, \mathrm{t}, J=7.2 \mathrm{~Hz}) ;{ }^{13} \mathrm{C} \delta 148.6,146.9,140.9,138.5,132.7,131.9$, $131.8,131.7,129.2,128.4,128.1,127.8,125.9,124.9,124.5,123.1,93.3,93.2,87.9,82.0,75.5$, 31.1, 25.0, 15.2; MS $m / z 770\left(\mathrm{M}^{+}\right), 753$, 736; HRMS calcd for $\mathrm{C}_{58} \mathrm{H}_{42} \mathrm{O}_{2}$ 770.3185, found 770.3160.

Compounds 165-168. To a flask containing $0.05 \mathrm{~mL}(0.7 \mathrm{mmol})$ of thionyl chloride in $10 \mathrm{~mL}$ of diethyl ether under a nitrogen atmosphere at $0{ }^{\circ} \mathrm{C}$ was added $0.08 \mathrm{~mL}(1.0 \mathrm{mmol})$ of pyridine in $5 \mathrm{~mL}$ of diethyl ether via cannula. After $10 \mathrm{~min}, 0.094 \mathrm{~g}(0.122 \mathrm{mmol})$ of $157 \mathrm{a}$ in $20 \mathrm{~mL}$ of diethyl ether was introduced slowly via cannula. After $5 \mathrm{~h}$ at $0{ }^{\circ} \mathrm{C}$, the reaction mixture was allowed to warm to rt. After an additional $2 \mathrm{~h}$ at $\mathrm{rt}, 10 \mathrm{~mL}$ of water was introduced, and the organic layer was separated. The aqueous layer was back extracted with methylene chloride. The combined organic layers were washed with water, dried over sodium sulfate, and concentrated. Flash column chromatography (silica gel/50\% methylene chloride in hexanes) provided $0.008 \mathrm{~g}$ of $165(0.010 \mathrm{mmol}, 8 \%)$ as a pink solid, $0.0030 \mathrm{~g}$ of $166(0.0037 \mathrm{mmol}, 3 \%)$ as a dark solid, $0.026 \mathrm{~g}$ of $167(0.035 \mathrm{mmol}, 28 \%)$ as a dark brown solid, and $0.029 \mathrm{~g}$ of $\mathbf{1 6 8}$ $(0.036 \mathrm{mmol}, 30 \%$, trans:cis $=5: 1)$ as an orange solid. Compound 165: mp $266-269{ }^{\circ} \mathrm{C}$; IR $1701,749 \mathrm{~cm}^{-1} ;{ }^{1} \mathrm{H} \delta 9.35(2 \mathrm{H}, \mathrm{dd}, J=7.9,1.2 \mathrm{~Hz}), 7.93(2 \mathrm{H}, \mathrm{d}, J=7.2 \mathrm{~Hz}), 7.70-7.26(16 \mathrm{H}$, m), $7.21(2 \mathrm{H}, \mathrm{td}, J=7.3,1.0 \mathrm{~Hz}), 7.12(2 \mathrm{H}, \mathrm{td}, J=7.7,1.2 \mathrm{~Hz}), 5.96(2 \mathrm{H}, \mathrm{d}, J=7.7 \mathrm{~Hz}), 3.55$ (2 H, br), 2.64 (2 H, m), 1.25 (4 H, m), 0.49 (6 H, t, $J=6.8 \mathrm{~Hz}) ;{ }^{13} \mathrm{C} \delta$ 193.7, 149.3, 144.2, 143.7, $141.5,141.2,140.7,138.6,138.3,137.6,136.9,135.6,134.1,130.2,129.4,129.1,128.94$ 
$128.87,128.7,128.2,127.0,126.7,123.7,123.5,35.1,25.1,14.3 ; \mathrm{MS} m / z 769\left(\mathrm{MH}^{+}\right), 768$ HRMS calcd for $\mathrm{C}_{58} \mathrm{H}_{40} \mathrm{O}_{2} 768.3028$, found 768.3021. Recrystallization of $\mathbf{1 6 5}$ from $\mathrm{CH}_{2} \mathrm{Cl}_{2} / 2$ propanol produced a crystal suitable for X-ray structure analysis (Figure 5). Compound 166: IR 1447, 753, $691 \mathrm{~cm}^{-1} ;{ }^{1} \mathrm{H} \delta 8.73(1 \mathrm{H}, \mathrm{d}, J=7.2 \mathrm{~Hz}), 8.40(1 \mathrm{H}, \mathrm{d}, J=6.9 \mathrm{~Hz}), 8.29(1 \mathrm{H}, \mathrm{d}, J=$ $7.4 \mathrm{~Hz}), 7.85(1 \mathrm{H}, \mathrm{d}, J=7.2 \mathrm{~Hz}), 7.67-7.16(19 \mathrm{H}, \mathrm{m}), 7.01(1 \mathrm{H}, \mathrm{t}, J=7.5 \mathrm{~Hz}), 6.86(1 \mathrm{H}, \mathrm{t}, J=$ $7.7 \mathrm{~Hz}), 5.48(1 \mathrm{H}, \mathrm{d}, J=7.7 \mathrm{~Hz}), 2.32-2.22(1 \mathrm{H}, \mathrm{m}), 2.2-2.0(1 \mathrm{H}, \mathrm{m}), 1.8-1.4(4 \mathrm{H}, \mathrm{m})$, 1.12-0.96 (1 H, m), 0.9-0.8 (1 H, m), $0.69(3 \mathrm{H}, \mathrm{t}, J=7.3 \mathrm{~Hz}), 0.46(3 \mathrm{H}, \mathrm{t}, J=7.1 \mathrm{~Hz}) ; \mathrm{MS} m / z$ 790, $771\left(\mathrm{M}^{+}-\mathrm{Cl}\right)$, 728. Compound 167: mp 275-277 ${ }^{\circ} \mathrm{C}$; IR (KBr) 2211, 1695, $761 \mathrm{~cm}^{-1} ;{ }^{1} \mathrm{H} \delta$ $9.44(1 \mathrm{H}, \mathrm{dd}, J=6.9,1.7 \mathrm{~Hz}), 8.64(1 \mathrm{H}, \mathrm{dd}, J=6.9,1.5 \mathrm{~Hz}), 8.38(1 \mathrm{H}, \mathrm{d}, J=7.7 \mathrm{~Hz}), 7.78(1$ $\mathrm{H}, \mathrm{d}, J=7.4 \mathrm{~Hz}), 7.68(1 \mathrm{H}, \mathrm{d}, J=7.2 \mathrm{~Hz}), 7.64-7.31(16 \mathrm{H}, \mathrm{m}), 7.26(1 \mathrm{H}, \mathrm{td}, J=7.5,1.0 \mathrm{~Hz})$, $7.17(1 \mathrm{H}, \mathrm{td}, J=7.4,0.7 \mathrm{~Hz}), 7.03(1 \mathrm{H}, \mathrm{td}, J=7.7,1.2 \mathrm{~Hz}), 6.96(1 \mathrm{H}, \mathrm{td}, J=7.4,0.7 \mathrm{~Hz}), 5.20$ $(1 \mathrm{H}, \mathrm{d}, J=7.7 \mathrm{~Hz}), 2.71(2 \mathrm{H}, \mathrm{m}), 2.12(2 \mathrm{H}, \mathrm{m}), 1.02(4 \mathrm{H}$, sextet, $J=7.9 \mathrm{~Hz}), 0.68(6 \mathrm{H}, \mathrm{t}, J=$ $7.3 \mathrm{~Hz}) ;{ }^{13} \mathrm{C} \delta 193.8,153.3,145.3,145.0,144.4,144.3,141.2,140.0,139.4,137.2,137.0,136.5$, $136.3,135.2,134.2,132.4,132.0,131.8,131.6,130.7,130.1,129.1,128.94,128.87,128.6$ $128.5,128.4,128.2,128.1,127.7,126.9,126.1,125.8,125.3,125.0,124.3,123.7,123.6,123.1$, $120.5,118.5,102.6,93.7,89.0,88.4,51.6,42.5,18.5,14.1$; MS $m / z 753\left(\mathrm{MH}^{+}\right), 752,709$; HRMS calcd for $\mathrm{C}_{58} \mathrm{H}_{40} \mathrm{O}$ 752.3079, found 752.3048. Recrystallization of $\mathbf{1 6 7}$ from $\mathrm{CH}_{2} \mathrm{Cl}_{2} / 2$ propanol produced a crystal suitable for X-ray structure analysis (Figure 8). Compound 168: $\mathrm{mp}$ $>340{ }^{\circ} \mathrm{C}$; IR 1640, 1424, 1196, $753 \mathrm{~cm}^{-1} ;{ }^{1} \mathrm{H} \delta$ (trans isomer) $8.67(2 \mathrm{H}, \mathrm{d}, J=7.7 \mathrm{~Hz}), 7.87(2$ H, t, $J=7.4 \mathrm{~Hz}), 7.56-7.20(22 \mathrm{H}, \mathrm{m}), 2.54(2 \mathrm{H}, \mathrm{m}), 2.42(2 \mathrm{H}, \mathrm{m}), 1.27(2 \mathrm{H}, \mathrm{m}), 1.03(2 \mathrm{H}$, $\mathrm{m}), 0.44(6 \mathrm{H}, \mathrm{t}, J=7.2 \mathrm{~Hz}) ;{ }^{13} \mathrm{C} \delta$ (trans isomer) $152.4,148.8,148.1,145.7,144.0,141.1,140.4$, $139.3,134.9,131.9,130.2,129.3,129.0,128.5,128.2,127.8,127.3,125.0,124.5,123.7,123.2$ $120.0,111.5,65.6,30.2,25.2,14.5 ;{ }^{13} \mathrm{C} \delta$ (cis isomer, partial) 151.9, 149.0, 145.9, 144.01, 
140.97, 139.2, 135.0, 132.1, 130.0, 129.4, 128.8, 127.6, 120.1, 112.0, 65.55, 14.54; MS m/z 807 $\left(\mathrm{MH}^{+}\right), 763,720$; HRMS calcd for $\mathrm{C}_{58} \mathrm{H}_{41} \mathrm{Cl}_{2}$ 807.2585, found 807.2569. Recrystallization of 168 from $\mathrm{CH}_{2} \mathrm{Cl}_{2} / 2$-propanol produced a crystal of the trans isomer suitable for $\mathrm{X}$-ray structure analysis (Figure 9).

Diester 177. A mixture of $0.454 \mathrm{~g}(1.30 \mathrm{mmol})$ of $\mathbf{1 6 2}$ and $0.161 \mathrm{~g}(1.31 \mathrm{mmol})$ of 1,4-dichloro2-butyne in $10 \mathrm{~mL}$ of mesitylene was heated under reflux for $72 \mathrm{~h}$. The solvent was removed in vacuo. Flash column chromatography (silica gel $/ 20 \%$ diethyl ether in hexanes) afforded $0.480 \mathrm{~g}$ of $\mathbf{1 7 7}(1.08 \mathrm{mmol}, 83 \%)$ as a wax-like white solid: $\mathrm{mp} 150-152{ }^{\circ} \mathrm{C}$; IR $1731,1208,697 \mathrm{~cm}^{-1}$; ${ }^{1} \mathrm{H} \delta$ 7.16-7.11 (6 H, m), 7.02-6.97 (4 H, m), $4.85(4 \mathrm{H}, \mathrm{s}), 3.47(6 \mathrm{H}, \mathrm{s}) ;{ }^{13} \mathrm{C} \delta 168.2,140.5$, 137.3, 137.2, 133.0, 129.6, 127.5, 127.4, 52.2, 39.0; MS m/z $442\left(\mathrm{M}^{+}\right), 407,391,375$.

Diester 178. A mixture of $0.521 \mathrm{~g}(1.18 \mathrm{mmol})$ of $177,0.97 \mathrm{~mL}(3.60 \mathrm{mmol})$ of tributyltin hydride, and $10 \mathrm{mg}(0.06 \mathrm{mmol})$ of AIBN in $25 \mathrm{~mL}$ of benzene was heated under reflux for $6 \mathrm{~h}$. The reaction mixture was washed with a $10 \%$ potassium fluoride solution followed by filtration to remove the white precipitate. The filtrate was extracted with diethyl ether. The combined organic layers were washed with water, dried over magnesium sulfate, and concentrated. Flash column chromatography (silica gel $/ 10 \%$ diethyl ether in hexanes) afforded $0.348 \mathrm{~g}$ of $\mathbf{1 7 8}(0.93$ mmol, $79 \%$ ) as a wax-like white solid: $\mathrm{mp} 145-147{ }^{\circ} \mathrm{C}$; IR 1729, $1207,702 \mathrm{~cm}^{-1} ;{ }^{1} \mathrm{H} \delta$ 7.12-7.07 (6 H, m), 7.03-6.97 (4 H, m), $3.47(6 \mathrm{H}, \mathrm{s}), 2.32(6 \mathrm{H}, \mathrm{s}) ;{ }^{13} \mathrm{C} \delta 170.0,138.3,136.5$, 136.2, 132.7, 130.0, 127.3, 126.8, 51.8, 17.1; MS m/z $374\left(\mathrm{M}^{+}\right), 359,343,311$.

Diketone 179. To a flask containing $0.347 \mathrm{~g}(0.93 \mathrm{mmol})$ of 178 was added $7 \mathrm{~mL}$ of concentrated sulfuric acid. The mixture was swirled periodically until the solid was dissolved in the sulfuric acid at rt. After $3 \mathrm{~h}$, the reaction mixture was poured into an ice-water mixture and then was extracted with diethyl ether. The combined organic extracts were washed with water, 
dried over magnesium sulfate, and concentrated. Recrystallization of the crude yellow solid from $95 \%$ ethanol afforded $0.184 \mathrm{~g}$ of $\mathbf{1 7 9}(0.59 \mathrm{mmol}, 64 \%)$ as bright-yellow crystals: $\mathrm{mp}$ 260-263 ${ }^{\circ} \mathrm{C}$; IR (KBr) 1699, 756, $714 \mathrm{~cm}^{-1} ;{ }^{1} \mathrm{H} \delta 8.02(2 \mathrm{H}, \mathrm{d}, J=7.7 \mathrm{~Hz}), 7.74(2 \mathrm{H}, \mathrm{d}, J=7.4$ Hz), $7.56(2 \mathrm{H}, \mathrm{td}, J=7.7,1.2 \mathrm{~Hz}), 7.37(2 \mathrm{H}, \mathrm{t}, J=7.3 \mathrm{~Hz}), 2.62(6 \mathrm{H}, \mathrm{s}) ;{ }^{13} \mathrm{C} \delta 194.1,142.8$, 141.9, 136.3, 135.5, 135.4, 134.7, 129.1, 124.5, 123.5, 12.9; MS m/z $310\left(\mathrm{M}^{+}\right), 295,281$.

Diol 157b. To a solution of $0.264 \mathrm{~g}(1.31 \mathrm{mmol})$ of 1-(2-ethynylphenyl)-2-phenylethyne in 20 $\mathrm{mL}$ of diethyl ether under a nitrogen atmosphere at $0{ }^{\circ} \mathrm{C}$ was added $0.40 \mathrm{~mL}$ of a $2.5 \mathrm{M}$ solution of $n$-butyllithium $(1.00 \mathrm{mmol})$ in hexanes. The reaction mixture was then allowed to warm to rt. After $30 \mathrm{~min}$ at $\mathrm{rt}$, a solution of $0.123 \mathrm{~g}(0.40 \mathrm{mmol})$ of 179 in $200 \mathrm{~mL}$ of diethyl ether was introduced via cannula. After an additional $2 \mathrm{~h}, 5 \mathrm{~mL}$ of water was introduced, and the reaction mixture was extracted with diethyl ether. The combined organic extracts were washed with brine and water, dried over sodium sulfate, and concentrated. Flash column chromatography (silica gel $/ 30 \%$ diethyl ether in hexanes) provided $0.266 \mathrm{~g}$ of $\mathbf{1 5 7 b}(0.37 \mathrm{mmol}, 94 \%$, a mixture of the trans and cis isomers, isomer ratio $=2: 1$ ) as a light brown solid: $\mathrm{mp} 125-128^{\circ} \mathrm{C}$; IR 3523 , 3404, 2253, $2217 \mathrm{~cm}^{-1} ;{ }^{1} \mathrm{H} \delta 8.27(2 \mathrm{H}, \mathrm{d}, J=7.7 \mathrm{~Hz}), 7.85(2 \mathrm{H}, \mathrm{d}, J=7.4 \mathrm{~Hz}), 7.50-7.44(6 \mathrm{H}$, m), 7.33-7.18 (16 H, m), $2.63(6 \mathrm{H}, \mathrm{s}), 2.42(2 \mathrm{H}, \mathrm{s}) ;{ }^{13} \mathrm{C} \delta 148.0,146.4,138.8,136.1,132.3$, $131.8,131.6,129.3,128.2,127.8,125.9,124.8,124.5,123.2,123.0,93.2,92.6,87.9,82.3,75.3$, 15.3. A minor set of ${ }^{13} \mathrm{C}$ signals due to the presence of the minor isomer was also observed.; MS $m / z 714\left(\mathrm{M}^{+}\right), 697,680$; HRMS calcd for $\mathrm{C}_{54} \mathrm{H}_{34} \mathrm{O}_{2}$ 714.2559, found 714.2548.

Compounds 180-182. To a solution of $0.130 \mathrm{~g}(0.182 \mathrm{mmol})$ of $157 \mathrm{~b}$ in $20 \mathrm{~mL}$ of diethyl ether under a nitrogen atmosphere at $0{ }^{\circ} \mathrm{C}$ was added a mixture of $0.05 \mathrm{~mL}(0.7 \mathrm{mmol})$ of thionyl chloride and $0.12 \mathrm{~mL}(1.5 \mathrm{mmol})$ of pyridine in $30 \mathrm{~mL}$ of diethyl ether slowly via cannula. The reaction mixture was allowed to warm to rt. After $6 \mathrm{~h}, 10 \mathrm{~mL}$ of water was introduced, and the 
organic layer was separated. The aqueous layer was back extracted with methylene chloride. The combined organic layers were washed with water, dried over sodium sulfate, and concentrated. Flash column chromatography (silica gel/50\% methylene chloride in hexanes) provided $0.0065 \mathrm{~g}$ of $\mathbf{1 8 0}(0.009 \mathrm{mmol}, 5 \%)$ as a pink solid, $0.0027 \mathrm{~g}$ of $181(0.0036 \mathrm{mmol}, 2 \%)$ as a dark solid, and $0.054 \mathrm{~g}$ of $\mathbf{1 8 2}(0.076 \mathrm{mmol}, 42 \%)$ as a deep green solid. Compound $\mathbf{1 8 0}$ : mp 108-110 ${ }^{\circ} \mathrm{C}$; IR 1705, 1598, $747 \mathrm{~cm}^{-1} ;{ }^{1} \mathrm{H} \delta 9.35(2 \mathrm{H}, \mathrm{dd}, J=7.2,1.5 \mathrm{~Hz}), 7.70(2 \mathrm{H}, \mathrm{d}, J=$ $7.7 \mathrm{~Hz}), 7.64-7.26(16 \mathrm{H}, \mathrm{m}), 7.21(2 \mathrm{H}, \mathrm{td}, J=7.4,1.0 \mathrm{~Hz}), 7.12(2 \mathrm{H}, \mathrm{td}, J=7.4,1.2 \mathrm{~Hz}), 6.04$ $(2 \mathrm{H}, \mathrm{d}, J=7.4 \mathrm{~Hz}), 2.27(6 \mathrm{H}, \mathrm{s}) ;{ }^{13} \mathrm{C} \delta 193.9,144.3,143.5,142.7,141.6,140.6,140.3,139.3$, $138.9,138.2,137.8,135.6,134.1,129.5,129.4,129.0,128.8,128.5,128.2,127.2,126.9,125.2$ 123.8, 123.4, 22.6; MS $m / z 712\left(\mathrm{M}^{+}\right), 419,391$; HRMS calcd for $\mathrm{C}_{54} \mathrm{H}_{32} \mathrm{O}_{2}$ 712.2402, found 712.2388. Compound 181: IR 1449, $756 \mathrm{~cm}^{-1} ;{ }^{1} \mathrm{H} \delta 8.70(1 \mathrm{H}, \mathrm{d}, J=7.7 \mathrm{~Hz}), 8.39(1 \mathrm{H}, \mathrm{d}, J=$ $7.9 \mathrm{~Hz}), 8.27(1 \mathrm{H}, \mathrm{d}, J=7.4 \mathrm{~Hz}), 7.77(1 \mathrm{H}, \mathrm{d}, J=7.4 \mathrm{~Hz}), 7.70-7.23(19 \mathrm{H}, \mathrm{m}), 7.00(1 \mathrm{H}, \mathrm{t}, J$ $=7.4 \mathrm{~Hz}), 6.86(1 \mathrm{H}, \mathrm{t}, J=7.9 \mathrm{~Hz}), 5.54(1 \mathrm{H}, \mathrm{d}, J=7.6 \mathrm{~Hz}), 1.77(3 \mathrm{H}, \mathrm{s}), 1.56(3 \mathrm{H}, \mathrm{s}) ; \mathrm{MS} m / z$ 732, $715\left(\mathrm{M}^{+}-\mathrm{Cl}\right)$. Compound 182: $\mathrm{mp}>300{ }^{\circ} \mathrm{C}$; IR $(\mathrm{KBr}) 1443,756 \mathrm{~cm}^{-1} ;{ }^{1} \mathrm{H} \delta 8.72(1 \mathrm{H}, \mathrm{d}, J$ $=7.2 \mathrm{~Hz}), 8.34(1 \mathrm{H}, \mathrm{d}, J=7.4 \mathrm{~Hz}), 8.23(1 \mathrm{H}, \mathrm{d}, J=7.4 \mathrm{~Hz}), 7.67(1 \mathrm{H}, \mathrm{d}, J=7.4 \mathrm{~Hz})$, 7.61-7.20 (19 H, m), $7.02(1 \mathrm{H}, \mathrm{t}, J=7.3 \mathrm{~Hz}), 6.89(1 \mathrm{H}, \mathrm{td}, J=7.7,1.0 \mathrm{~Hz}), 6.23(1 \mathrm{H}, \mathrm{s}), 5.80$ $(1 \mathrm{H}, \mathrm{d}, J=7.9 \mathrm{~Hz}), 5.39(1 \mathrm{H}, \mathrm{s}), 1.85(3 \mathrm{H}, \mathrm{s}) ;{ }^{13} \mathrm{C} \delta 148.5,145.9,144.7,142.8,142.1,141.8$, 141.4, 140.0, 138.4, 138.1, 137.1, 134.9, 133.3, 132.4, 132.3, 132.1, 132.0, 129.5, 129.4, 129.3, $128.6,128.5,128.4,128.3,128.0,127.9,126.6,126.3,126.2,126.1,125.6,125.5,125.3,125.0$ 124.8, 123.1, 123.0, 121.4, 120.4, 119.1, 116.1, 101.6, 93.7, 89.2, 88.4, 48.1, 34.1; MS m/z 714 $\left(\mathrm{M}^{+}\right)$, 699. Recrystallization of $\mathbf{1 8 2}$ from $\mathrm{CH}_{2} \mathrm{Cl}_{2} / 2$-propanol produced a crystal suitable for $\mathrm{X}$ ray structure analysis (Figure 10). 
Diketone 184. To a flask containing $0.660 \mathrm{~g}(1.67 \mathrm{mmol})$ of $183^{55}$ was added $10 \mathrm{~mL}$ of concentrated sulfuric acid. The mixture was swirled periodically until the solid was dissolved in the sulfuric acid at rt. After $12 \mathrm{~h}$, the reaction mixture was poured into an ice-water mixture and then was extracted with a mixture of diethyl ether/THF solution. The combined organic extracts were washed with water, dried over magnesium sulfate, and concentrated. Recrystallization of the crude yellow solid from 95\% ethanol afforded $0.479 \mathrm{~g}$ of $\mathbf{1 8 4}(1.44 \mathrm{mmol}, 87 \%)$ as red crystals: $\mathrm{mp} 247-250{ }^{\circ} \mathrm{C}$; IR 1699, 750, $708 \mathrm{~cm}^{-1} ;{ }^{1} \mathrm{H} \delta 9.01(2 \mathrm{H}, \mathrm{dd}, J=6.7,3.5 \mathrm{~Hz}), 8.01(2$ H, d, $J=7.7 \mathrm{~Hz}), 7.72(2 \mathrm{H}, \mathrm{d}, J=7.2 \mathrm{~Hz}), 7.56(2 \mathrm{H}, \mathrm{td}, J=7.5,1.0 \mathrm{~Hz}), 7.50(2 \mathrm{H}, \mathrm{dd}, J=6.7$, $3.5 \mathrm{~Hz}), 7.36(2 \mathrm{H}, \mathrm{t}, J=7.4 \mathrm{~Hz}) ;{ }^{13} \mathrm{C} \delta 194.1,143.0,140.0,134.7,134.6,133.2,131.2,129.7$, 129.5, 124.53, 124.49, 123.6; MS m/z $332\left(\mathrm{M}^{+}\right), 304,281$.

Diol 157c. To a solution of $0.186 \mathrm{~g}(0.92 \mathrm{mmol})$ of 1-(2-ethynylphenyl)-2-phenylethyne in 20 $\mathrm{mL}$ of diethyl ether under a nitrogen atmosphere at $0{ }^{\circ} \mathrm{C}$ was added $0.35 \mathrm{~mL}$ of a $2.5 \mathrm{M}$ solution of $n$-butyllithium $(0.88 \mathrm{mmol})$ in hexanes. The reaction mixture was then allowed to warm to rt. After $30 \mathrm{~min}$ at $\mathrm{rt}$, a solution of $0.104 \mathrm{~g}(0.313 \mathrm{mmol})$ of $184 \mathrm{in} 50 \mathrm{~mL}$ of THF was introduced via cannula. After an additional $2 \mathrm{~h}, 5 \mathrm{~mL}$ of water was introduced, and the reaction mixture was extracted with diethyl ether. The combined organic extracts were washed with brine and water, dried over sodium sulfate, and concentrated. Flash column chromatography (silica gel/30\% diethyl ether in hexanes) provided $0.219 \mathrm{~g}$ of $157 \mathrm{c}(0.298 \mathrm{mmol}, 95 \%$, a mixture of the trans and cis isomers, isomer ratio $=3: 1)$ as a soil-colored solid. Some fractions were found to contain only one of the two isomers. Isomer 1: mp $118-121{ }^{\circ} \mathrm{C}$; IR $3391,2215,753 \mathrm{~cm}^{-1} ;{ }^{1} \mathrm{H} \delta 8.84(2$ $\mathrm{H}, \mathrm{dd}, J=6.6,3.3 \mathrm{~Hz}), 8.31(2 \mathrm{H}, \mathrm{d}, J=7.9 \mathrm{~Hz}), 7.94(2 \mathrm{H}, \mathrm{d}, J=7.4 \mathrm{~Hz}), 7.50-7.14(24 \mathrm{H}, \mathrm{m})$, $2.71(2 \mathrm{H}, \mathrm{s}) ;{ }^{13} \mathrm{C} \delta 148.9,145.0,139.1,132.6,132.3,131.8,131.7,129.40,129.35,128.4,128.3$, $128.2,127.8,127.0,126.1,125.8,124.7,124.4,123.5,123.0,93.3,92.9,87.9,83.2,75.4$; MS 
m/z $736\left(\mathrm{M}^{+}\right), 719,702$; HRMS calcd for $\mathrm{C}_{56} \mathrm{H}_{32} \mathrm{O}_{2}$ 736.2402, found 736.2436. Isomer 2: mp $132-135{ }^{\circ} \mathrm{C}$; IR $3355,2215,752 \mathrm{~cm}^{-1} ;{ }^{1} \mathrm{H} \delta 8.84(2 \mathrm{H}, \mathrm{dd}, J=6.7,3.2 \mathrm{~Hz}), 8.26(2 \mathrm{H}, \mathrm{d}, J=7.7$ $\mathrm{Hz}), 7.92(2 \mathrm{H}, \mathrm{d}, J=7.4 \mathrm{~Hz}), 7.52-7.37(8 \mathrm{H}, \mathrm{m}), 7.32-7.16(16 \mathrm{H}, \mathrm{m}), 2.76(2 \mathrm{H}, \mathrm{br} \mathrm{s}) ;{ }^{13} \mathrm{C} \delta$ $148.7,144.6,139.1,132.7,132.4,131.8,131.6,129.5,129.4,128.4,128.33,128.25,127.7$, 127.1, 126.1, 125.7, 124.7, 124.6, 123.5, 122.9, 93.5, 93.1, 87.8, 83.6, 75.3; MS $m / z 736\left(\mathrm{M}^{+}\right)$, $719,702$.

Compounds 185-187. To a solution of $0.309 \mathrm{~g}(0.42 \mathrm{mmol})$ of $157 \mathrm{c}$ in $30 \mathrm{~mL}$ of diethyl ether under a nitrogen atmosphere at $0{ }^{\circ} \mathrm{C}$ was added a mixture of $0.12 \mathrm{~mL}(1.6 \mathrm{mmol})$ of thionyl chloride and $0.20 \mathrm{~mL}$ ( $2.5 \mathrm{mmol})$ of pyridine in $20 \mathrm{~mL}$ of diethyl ether slowly via cannula. The reaction mixture was allowed to warm to rt. After $6 \mathrm{~h}$, the solvent was removed in vacuo. Water $(10 \mathrm{~mL})$ and methylene chloride $(50 \mathrm{~mL})$ were introduced, and the organic layer was separated. The aqueous layer was back extracted with methylene chloride. The combined organic layers were washed with water, dried over magnesium sulfate, and concentrated. Flash column chromatography (silica gel/30\% methylene chloride in hexanes) provided $0.084 \mathrm{~g}$ of $\mathbf{1 8 5}(0.11$ mmol, $26 \%$, trans:cis $=3: 1)$ as a green-yellow solid, $0.043 \mathrm{~g}$ of $186(0.057 \mathrm{mmol}, 14 \%$, a mixture of the trans and cis isomers, isomer ratio $=2: 1$ ) as a yellow solid, and $0.0034 \mathrm{~g}$ of $\mathbf{1 8 7}$ (0.005 mmol, 1\%) as a red solid. Compound 185: $\mathrm{mp}>340{ }^{\circ} \mathrm{C}$; IR 1637, 1425, $753 \mathrm{~cm}^{-1} ;{ }^{1} \mathrm{H} \delta$ (trans isomer) $8.78(2 \mathrm{H}, \mathrm{d}, J=7.7 \mathrm{~Hz}), 7.96(2 \mathrm{H}, \mathrm{d}, J=7.4 \mathrm{~Hz}), 7.87(2 \mathrm{H}, \mathrm{dd}, J=6.7,3.5 \mathrm{~Hz})$, 7.62-7.48 (8 H, m), 7.44-7.33 (4 H, m), $7.19(8 \mathrm{H}, \mathrm{s}), 7.13(2 \mathrm{H}, \mathrm{s}), 7.08(2 \mathrm{H}, \mathrm{dd}, J=6.4,3.2$ $\mathrm{Hz}) ;{ }^{13} \mathrm{C} \delta$ (trans isomer) 153.1, 149.0, 148.5, 146.0, 142.8, 141.0, 139.7, 135.1, 131.7, 130.9, $130.4,129.5,129.0,128.8,128.7,128.3,127.7,127.5,126.7,125.1,124.4,124.1,123.8,123.6$ 120.3, 111.9, 65.6. A minor set of ${ }^{13} \mathrm{C}$ signals due to the presence of the cis isomer was also observed.; MS m/z $772\left(\mathrm{M}^{+}\right)$, 737; HRMS calcd for $\mathrm{C}_{56} \mathrm{H}_{30} \mathrm{Cl}_{2}$ 772.1725, found 772.1766. 
Recrystallization of $\mathbf{1 8 5}$ from $\mathrm{CH}_{2} \mathrm{Cl}_{2} / 2$-propanol produced a crystal of the trans isomer suitable for X-ray structure analysis (Figure 11). Compound 186: Some fractions were found to contain only one of the two isomers. Isomer 1 : $\mathrm{mp}>340{ }^{\circ} \mathrm{C}$; IR 3378, $1425,746 \mathrm{~cm}^{-1} ;{ }^{1} \mathrm{H} \delta 9.11(1 \mathrm{H}, \mathrm{d}$, $J=8.7 \mathrm{~Hz}) ; 8.87(1 \mathrm{H}, \mathrm{d}, J=6.9 \mathrm{~Hz}), 8.76(1 \mathrm{H}, \mathrm{d}, J=7.7 \mathrm{~Hz}), 8.03(1 \mathrm{H}, \mathrm{d}, J=8.7 \mathrm{~Hz}), 7.99(1$ $\mathrm{H}, \mathrm{d}, J=7.4 \mathrm{~Hz}), 7.79(1 \mathrm{H}, \mathrm{d}, J=7.7 \mathrm{~Hz}), 7.71-7.08(22 \mathrm{H}, \mathrm{m}), 6.74(1 \mathrm{H}, \mathrm{br} \mathrm{s}), 6.52(1 \mathrm{H}, \mathrm{d}, J$ $=7.9 \mathrm{~Hz}), 2.50(1 \mathrm{H}, \mathrm{br} \mathrm{s}) ;{ }^{13} \mathrm{C} \delta 153.0,149.1,148.6,146.1,145.3,142.2,141.9,141.2,139.6$, $139.5,138.5,138.1,137.7,136.7,136.0,135.4,135.0,134.2,132.0,131.5,130.8,130.3,130.1$, $129.6,129.5,129.0,128.93,128.8,128.3,128.2,127.74,127.66,126.6,126.5,125.8,125.2$, 124.9, 124.4, 124.1, 123.7, 123.0, 120.4, 112.1, 75.6, 65.6; MS m/z $754\left(\mathrm{M}^{+}\right)$, 737; HRMS calcd for $\mathrm{C}_{56} \mathrm{H}_{31} \mathrm{ClO} 754.2063$, found 754.2039. Isomer 2: $\mathrm{mp}>340{ }^{\circ} \mathrm{C}$; IR 3434, $1430,749 \mathrm{~cm}^{-1} ;{ }^{1} \mathrm{H}$ $\delta 9.04(1 \mathrm{H}, \mathrm{d}, J=8.4 \mathrm{~Hz}) ; 8.84(1 \mathrm{H}, \mathrm{d}, J=6.9 \mathrm{~Hz}), 8.76(1 \mathrm{H}, \mathrm{d}, J=7.7 \mathrm{~Hz}), 8.00(1 \mathrm{H}, \mathrm{dd}, J=$ 7.7, 1.0 Hz), $7.98(1 \mathrm{H}, \mathrm{d}, J=7.4 \mathrm{~Hz}), 7.77(1 \mathrm{H}, \mathrm{d}, J=7.4 \mathrm{~Hz}), 7.71-7.26(16 \mathrm{H}, \mathrm{m}), 7.13-7.08$

$(6 \mathrm{H}, \mathrm{m}), 6.74(1 \mathrm{H}, \mathrm{d}, J=7.7 \mathrm{~Hz}), 6.52(1 \mathrm{H}, \mathrm{d}, J=7.9 \mathrm{~Hz}), 2.46(1 \mathrm{H}, \mathrm{d}, J=7.7 \mathrm{~Hz}) ;{ }^{13} \mathrm{C} \delta$ 153.0, 149.1, 148.6, 146.0, 145.2, 141.9, 141.8, 141.2, 139.6, 139.5, 138.5, 138.1, 137.7, 136.6, $136.1,135.5,135.0,134.1,132.1,131.6,131.5,130.7,130.3,130.1,129.5,128.99,128.94$ $128.87,128.77,128.3,128.2,128.1,127.7,126.62,126.56,126.48,125.6,125.2,124.9,124.42$, 124.37, 124.1, 123.9, 123.7, 123.0, 120.4, 112.0, 75.5, 65.4; MS m/z $754\left(\mathrm{M}^{+}\right)$, 737. Compound 187: $\mathrm{mp}>340{ }^{\circ} \mathrm{C}$; IR 1702, 1602, $750 \mathrm{~cm}^{-1} ;{ }^{1} \mathrm{H} \delta 8.61(2 \mathrm{H}, \mathrm{dd}, J=7.4,2.7 \mathrm{~Hz}), 8.29(1 \mathrm{H}, \mathrm{d}, J$ $=8.7 \mathrm{~Hz}), 7.97(1 \mathrm{H}, \mathrm{d}, J=7.4 \mathrm{~Hz}), 7.88(1 \mathrm{H}, \mathrm{d}, J=8.2 \mathrm{~Hz}), 7.82(1 \mathrm{H}, \mathrm{dd}, J=7.7,1.6 \mathrm{~Hz})$, 7.68-7.18 (22 H, m), $6.47(1 \mathrm{H}, \mathrm{d}, J=6.9 \mathrm{~Hz}) ;{ }^{13} \mathrm{C} \delta 192.8,152.9,149.1,148.5,146.1,144.8$, 143.9, 139.1, 138.9, 138.3, 137.7, 136.8, 136.0, 134.9, 134.7, 134.5, 132.9, 131.7, 131.6, 130.3, $130.25,130.21,130.03,130.01,129.96,129.54,129.45,129.0,128.8,128.6,128.5,128.4,127.9$ 
127.7, 127.1, 126.5, 125.6, 125.2, 124.4, 124.3, 124.1, 123.8, 123.3, 122.9, 120.4, 112.1, 65.4;

MS $m / z 752\left(\mathrm{M}^{+}\right), 705,483,469$; HRMS calcd for $\mathrm{C}_{56} \mathrm{H}_{29} \mathrm{ClO} 752.1907$, found 752.1915.

Compound 188b. To a mixture of $0.030 \mathrm{~g}(0.042 \mathrm{mmol})$ of $157 \mathrm{~b}$ and $0.0502 \mathrm{~g}(0.43 \mathrm{mmol})$ of triethylsilane in $10 \mathrm{~mL}$ of methylene chloride under a nitrogen atmosphere at -30 to $-40{ }^{\circ} \mathrm{C}$ was added $0.05 \mathrm{~mL}$ trifluoroacetic acid $(0.074 \mathrm{~g}, 0.65 \mathrm{mmol})$. After $30 \mathrm{~min}$ at $-30{ }^{\circ} \mathrm{C}$, the reaction mixture was allowed to warm to room temperature. $0.77 \mathrm{~g}(7.26 \mathrm{mmol})$ sodium carbonate was added followed by $10 \mathrm{~mL}$ of water and $20 \mathrm{~mL}$ of diethyl ether. The organic layer was separated. The aqueous layer was back extracted with diethyl ether. The combined organic extracts were washed with brine and water, dried over sodium sulfate, and concentrated. Flash column chromatography (silica gel $/ 5 \%$ diethyl ether in hexanes) provided $0.025 \mathrm{~g}$ of $\mathbf{1 8 8 b}(0.037 \mathrm{mmol}$, $87 \%, 2: 1$ mixture of diastereomers) as a light brown solid: $\mathrm{mp} 98-100{ }^{\circ} \mathrm{C}$; IR 2222, 2212, 911 , 757, 732, $691 \mathrm{~cm}^{-1} ;{ }^{1} \mathrm{H} \delta 8.48(2 \mathrm{H}, \mathrm{d}, J=7.9 \mathrm{~Hz}), 7.86(2 \mathrm{H}, \mathrm{d}, J=7.2 \mathrm{~Hz}), 7.52-7.43(6 \mathrm{H}, \mathrm{m})$, 7.35-7.12 (16 H, m), 5.14-5.06 (2 H, s), 2.59-2.49 (6 H, s).

Compound 191. To a solution of $0.422 \mathrm{~g}(2.09 \mathrm{mmol})$ of 1-(2-ethynylphenyl)-2-phenylethyne in $20 \mathrm{~mL}$ of diethyl ether under a nitrogen atmosphere at $0{ }^{\circ} \mathrm{C}$ was added $0.78 \mathrm{~mL}$ of a $2.5 \mathrm{M}$ solution of $n$-butyllithium $(1.95 \mathrm{mmol})$ in hexanes. The reaction mixture was then allowed to warm to room temperature. After $30 \mathrm{~min}$ at room temperature, a solution of $0.257 \mathrm{~g}(1.43 \mathrm{mmol})$ of 9-fluorenone in $30 \mathrm{~mL}$ of diethyl ether was introduced dropwise via cannula. After an additional $2 \mathrm{~h}$ at room temperature, a solution of $0.145 \mathrm{~g}(1.43 \mathrm{mmol})$ of acetic anhydride in 10 $\mathrm{mL}$ of diethyl ether was introduced. After an additional $4 \mathrm{~h}$, to the reaction mixture, $0.033 \mathrm{~g}$ $(0.029 \mathrm{mmol})$ of $\mathrm{Pd}\left(\mathrm{PPh}_{3}\right)_{4}$ and $0.086(1.43 \mathrm{mmol})$ of 2-propanol in $5 \mathrm{~mL}$ THF were added, followed by $14.3 \mathrm{~mL}$ of a $0.1 \mathrm{M}$ solution of $\mathrm{SmI}_{2}(1.43 \mathrm{mmol})$ in THF. After $12 \mathrm{~h}$, a mixture of hexane and diethyl ether (4:1) was introduced to form ppt. The solid was collected by filtration 
to afford $0.177 \mathrm{~g}$ of $\mathbf{1 9 1}$ as brown crystals: $\mathrm{mp} 227-230^{\circ} \mathrm{C}$; IR 1441, 780, 754, 733, $693 \mathrm{~cm}^{-1}$; ${ }^{1} \mathrm{H} \delta 8.02-7.95(3 \mathrm{H}, \mathrm{m}), 7.65-7.42(10 \mathrm{H}, \mathrm{m}), 7.29(1 \mathrm{H}, \mathrm{t}, J=7.8 \mathrm{~Hz}), 7.09(1 \mathrm{H}, \mathrm{t}, J=7.5 \mathrm{~Hz})$, $6.71(1 \mathrm{H}, \mathrm{d}, J=7.9 \mathrm{~Hz}), 4.45(2 \mathrm{H}, \mathrm{s}) ;{ }^{13} \mathrm{C} \delta 143.8,141.2,140.0,139.9,139.0,138.1,137.9$, $136.3,134.0,131.5,131.0,130.2,129.7,128.7,127.9,127.4,127.23,127.17,126.7,125.7$, $125.1,123.7,123.0,121.6,119.6,35.4$.

Propargylic Acetate 190. The following procedure is representative for the preparation of the propargylic acetates. To a solution of $1.63 \mathrm{~g}(8.07 \mathrm{mmol})$ of 1-(2-ethynylphenyl)-2phenylethyne in $50 \mathrm{~mL}$ of diethyl ether under a nitrogen atmosphere at $0{ }^{\circ} \mathrm{C}$ was added $3.00 \mathrm{~mL}$ of a $2.5 \mathrm{M}$ solution of $n$-butyllithium $(7.50 \mathrm{mmol})$ in hexanes. The reaction mixture was then allowed to warm to room temperature. After $30 \mathrm{~min}$ at room temperature, a solution of $1.13 \mathrm{~g}$ (6.27 mmol) of 9-fluorenone in $50 \mathrm{~mL}$ of diethyl ether was introduced dropwise via cannula. After an additional $2 \mathrm{~h}$ at room temperature, a solution of $0.78 \mathrm{~g}(7.64 \mathrm{mmol})$ of acetic anhydride in $50 \mathrm{~mL}$ of diethyl ether was introduced, and the reaction mixture was stirred for $4 \mathrm{~h}$ before 20 $\mathrm{mL}$ of water was added. The organic layer was separated, and the aqueous layer was backextracted with diethyl ether. The combined organic extracts were washed with brine and water, dried over magnesium sulfate, and concentrated. A mixture of hexanes and diethyl ether (3:1, 10 $\mathrm{mL}$ ) was added to the residue, and the solution was cooled to $0{ }^{\circ} \mathrm{C}$. A solid precipitate appeared after ca. 15 min. The solid precipitate was collected by filtration and then washed with hexanes to furnish $2.20 \mathrm{~g}$ of 190 (5.19 mmol, 83\%) as a light brown solid: mp $120-122{ }^{\circ} \mathrm{C}$; IR 2219 , 1749, 1229, $757 \mathrm{~cm}^{-1} ;{ }^{1} \mathrm{H} \delta 7.91(2 \mathrm{H}, \mathrm{d}, J=7.7 \mathrm{~Hz}), 7.65(2 \mathrm{H}, \mathrm{d}, J=7.7 \mathrm{~Hz}), 7.50(2 \mathrm{H}, \mathrm{tm}, J=$ 7.4, $2 \mathrm{~Hz}), 7.40(2 \mathrm{H}, \mathrm{td}, J=7.4,0.7 \mathrm{~Hz}), 7.35-7.20(9 \mathrm{H}, \mathrm{m}), 2.02(3 \mathrm{H}, \mathrm{s}) ;{ }^{13} \mathrm{C} \delta$ 169.1, 144.1, $139.9,132.5,131.75,131.70,129.8,128.41,128.35,128.25,128.18,127.8,126.1,126.0,124.7$, 
123.1, 120.0, 93.2, 89.7, 87.8, 84.1, 79.6, 21.8; MS $m / z 424\left(\mathrm{M}^{+}\right), 380,366$; HRMS calcd for $\mathrm{C}_{31} \mathrm{H}_{20} \mathrm{O}_{2} 424.1463$, found 424.1466 .

Carboxylic Acid 274. The following procedure is representative for the preparation of the carboxylic acids. To a flask containing $1.60 \mathrm{~mL}$ of a $2.5 \mathrm{M}$ solution of $n$-butyllithium (4.00 mmol) in hexanes under a nitrogen atmosphere at $0{ }^{\circ} \mathrm{C}$ were added $0.56 \mathrm{~mL}(4.00 \mathrm{mmol})$ of diisopropylamine and then $5 \mathrm{~mL}$ of THF. After $30 \mathrm{~min}$ at $0{ }^{\circ} \mathrm{C}$, the reaction mixture was cooled to $-78{ }^{\circ} \mathrm{C}$. A solution of $0.85 \mathrm{~g}(2.00 \mathrm{mmol})$ of $\mathbf{1 9 0} \mathrm{in} 15 \mathrm{~mL}$ of THF was introduced dropwise via cannula. After $30 \mathrm{~min}$ at $-78{ }^{\circ} \mathrm{C}, 1 \mathrm{~mL}$ of $\mathrm{HMPA}$ and $4 \mathrm{~mL}$ of a $1.0 \mathrm{M}$ solution of TBDMSCl (4.00 mmol) in THF were introduced. The reaction mixture was allowed to warm to room temperature slowly and then heated to $45{ }^{\circ} \mathrm{C}$. After an additional $12 \mathrm{~h}$ at $45{ }^{\circ} \mathrm{C}$, the reaction mixture was allowed to cool to room temperature, and a mixture of $10 \mathrm{~mL}$ of acetic acid and $3.3 \mathrm{~mL}$ of water was introduced. After $12 \mathrm{~h}, 20 \mathrm{~mL}$ of diethyl ether was added, and the organic layer was separated. The aqueous layer was back extracted with diethyl ether. The combined organic layers were washed with water $(5 \times 30 \mathrm{~mL})$, dried over magnesium sulfate, and concentrated. Flash column chromatography (silica gel $/ 25 \%$ acetone in hexanes) provided $0.487 \mathrm{~g}$ of $274(1.15 \mathrm{mmol}, 57 \%)$ as a yellow solid: $\mathrm{mp} 258-260^{\circ} \mathrm{C}$; IR $3500-2600$ (br), 1708, $756 \mathrm{~cm}^{-1} ;{ }^{1} \mathrm{H} \delta 8.05(1 \mathrm{H}, \mathrm{d}, J=7.7 \mathrm{~Hz}), 8.02(1 \mathrm{H}, \mathrm{d}, J=7.7 \mathrm{~Hz}), 7.97(1 \mathrm{H}, \mathrm{d}, J=6.2 \mathrm{~Hz}), 7.68$ $(1 \mathrm{H}, \mathrm{d}, J=7.7 \mathrm{~Hz}), 7.64-7.44(9 \mathrm{H}, \mathrm{m}), 7.29(1 \mathrm{H}, \mathrm{t}, J=6.9 \mathrm{~Hz}), 7.10(1 \mathrm{H}, \mathrm{t}, J=7.4 \mathrm{~Hz}), 6.67$ $(1 \mathrm{H}, \mathrm{d}, J=7.7 \mathrm{~Hz}), 5.18(1 \mathrm{H}, \mathrm{dd}, J=10.5,1.4 \mathrm{~Hz}), 3.76(1 \mathrm{H}, \mathrm{dd}, J=16.6,2.2 \mathrm{~Hz}), 2.55(1 \mathrm{H}$, $\mathrm{dd}, J=16.6,10.9 \mathrm{~Hz}) ;{ }^{13} \mathrm{C} \delta 177.5,147.3,141.6,140.3,140.2,138.6,137.83,137.80,136.4$, $134.2,131.8,130.8,130.2,128.83,128.75,128.0,127.80,127.77,127.58,127.51,125.9,124.6$, 123.9, 123.7, 121.8, 119.8, 41.9, 38.5; MS $m / z 424\left(\mathrm{M}^{+}\right), 378,365$; HRMS calcd for $\mathrm{C}_{31} \mathrm{H}_{20} \mathrm{O}_{2}$ 424.1463, found 424.1466. 
Propargylic Acetate 279. The same procedure was repeated as described for 190 except that $0.08 \mathrm{~g}(0.39 \mathrm{mmol})$ of $\mathbf{2 7 5}$ was treated with 60, prepared from $0.140 \mathrm{~g}(0.69 \mathrm{mmol})$ of 1-(2ethynylphenyl)-2-phenylethyne and $0.25 \mathrm{~mL}$ of a $2.5 \mathrm{M}$ solution of $n$-butyllithium ( $0.63 \mathrm{mmol})$ in hexanes at $0{ }^{\circ} \mathrm{C}$, followed by $0.064 \mathrm{~g}(0.63 \mathrm{mmol})$ of acetic anhydride to afford $0.143 \mathrm{~g}$ of 279 (0.32 mmol, 81\%) as a light brown solid: $\mathrm{mp} 143-145^{\circ} \mathrm{C}$; IR 2214, 1749, 1226, $756 \mathrm{~cm}^{-1} ;{ }^{1} \mathrm{H} \delta$ 8.07-8.03 (2 H, m), 7.87-7.82 (4 H, m), 7.60-7.47 (4 H, m), 7.35-7.20 (7 H, m), 2.08 (3 H, s); ${ }^{13} \mathrm{C} \delta 169.4,143.2,135.7,132.5,131.7,131.6,128.5,128.4,128.2,128.1,127.9,127.8,126.0$, $125.8,125.4,124.7,123.3,123.0,93.2,89.1,87.8,84.7,81.1,21.6$.

Carboxylic Acid 283. The same procedure was repeated as described for 274 except that 0.143 $\mathrm{g}(0.32 \mathrm{mmol})$ of $\mathbf{2 7 9}$ was treated with LDA, prepared from $0.26 \mathrm{~mL}$ of a $2.5 \mathrm{M}$ solution of $n$ butyllithium $(0.65 \mathrm{mmol})$ in hexanes and $0.09 \mathrm{~mL}(0.65 \mathrm{mmol})$ of diisopropylamine, followed by $0.34 \mathrm{~mL}$ of HMPA and $0.65 \mathrm{~mL}$ of a $1.0 \mathrm{M}$ solution of TBDMSCl $(0.65 \mathrm{mmol})$ in THF. Hydrolysis with a mixture of $2.3 \mathrm{~mL}$ of acetic acid and $0.8 \mathrm{~mL}$ water provided $0.10 \mathrm{~g}$ of $\mathbf{2 8 3}$ (0.22 mmol, 70\%) as yellow crystals: mp $228-231^{\circ} \mathrm{C}$; IR 3500-2600 (br), 1703, 827, 750, 704 $\mathrm{cm}^{-1} ;{ }^{1} \mathrm{H} \delta 8.25(1 \mathrm{H}, \mathrm{d}, J=6.9 \mathrm{~Hz}), 8.01(1 \mathrm{H}, \mathrm{d}, J=8.4 \mathrm{~Hz}), 7.97(1 \mathrm{H}, \mathrm{t}, J=8.2 \mathrm{~Hz}), 7.86(1$ $\mathrm{H}, \mathrm{d}, J=8.7 \mathrm{~Hz}), 7.80(1 \mathrm{H}, \mathrm{t}, J=7.5 \mathrm{~Hz}), 7.73(1 \mathrm{H}, \mathrm{d}, J=7.7 \mathrm{~Hz}), 7.67-7.52(7 \mathrm{H}, \mathrm{m}), 7.30(1$ $\mathrm{H}, \mathrm{t}, J=7.9 \mathrm{~Hz}), 7.12(1 \mathrm{H}, \mathrm{t}, J=7.5 \mathrm{~Hz}), 6.77(1 \mathrm{H}, \mathrm{d}, J=7.9 \mathrm{~Hz}), 5.14(1 \mathrm{H}, \mathrm{dd}, J=10.9,2.6$ Hz), $3.94(1 \mathrm{H}, \mathrm{dd}, J=16.4,2.6 \mathrm{~Hz}), 2.79(1 \mathrm{H}, \mathrm{dd}, J=16.4,10.5 \mathrm{~Hz}) ;{ }^{13} \mathrm{C} \delta 177.3,146.7$, $144.6,141.1,138.9,137.8,135.9,135.2,133.9,132.7,132.5,131.3,130.0,128.9,128.8,128.3$, $128.1,127.9,127.5,127.4,126.8,126.7,126.6,125.8,125.3,124.78,124.74,124.66,123.7$, 42.2, 38.7; MS m/z $448\left(\mathrm{M}^{+}\right), 402,389$; HRMS calcd for $\mathrm{C}_{33} \mathrm{H}_{20} \mathrm{O}_{2}$ 448.1463, found 448.1451. Recrystallization of $\mathbf{2 8 3}$ from $\mathrm{CH}_{2} \mathrm{Cl}_{2}$ /2-propanol produced a crystal suitable for X-ray structure analysis (Figure 12). 
Propargylic Acetate 280. The same procedure was repeated as described for 190 except that $0.177 \mathrm{~g}(0.86 \mathrm{mmol})$ of 276 was treated with 60, prepared from $0.19 \mathrm{~g}(0.94 \mathrm{mmol})$ of 1-(2ethynylphenyl)-2-phenylethyne and $0.36 \mathrm{~mL}$ of a $2.5 \mathrm{M}$ solution of $n$-butyllithium ( $0.90 \mathrm{mmol})$ in hexanes, followed by $0.10 \mathrm{~g}(0.98 \mathrm{mmol})$ of acetic anhydride. A small sample of $\mathbf{2 8 0}$ was isolated as a light brown solid for structural elucidation: $\mathrm{mp} 146-148{ }^{\circ} \mathrm{C}$; IR $2226,1749,1226$, $756 \mathrm{~cm}^{-1} ;{ }^{1} \mathrm{H} \delta 7.71(2 \mathrm{H}, \mathrm{t}, J=4.0 \mathrm{~Hz}), 7.55-7.50(2 \mathrm{H}, \mathrm{m}), 7.41-7.23(7 \mathrm{H}, \mathrm{m}), 7.17-7.12(4$ $\mathrm{H}, \mathrm{m}), 3.21-3.02(4 \mathrm{H}, \mathrm{m}), 2.07(3 \mathrm{H}, \mathrm{s}) ;{ }^{13} \mathrm{C} \delta 169.3,141.8,137.2,132.5,131.7,130.5,128.8$, $128.24,128.20,128.1,127.9,127.7,125.9,124.8,124.1,123.1,93.2,89.4,87.9,84.0,81.0,25.6$, 21.6. As in the case of $\mathbf{2 8 5}$, the rest of the crude acetate $\mathbf{2 8 0}$ was used for the next step without further purification.

Carboxylic Acid 284. The same procedure was repeated as described for 274 except that 0.386 $\mathrm{g}(0.86 \mathrm{mmol})$ of the crude acetate $\mathbf{2 8 0}$ was treated with LDA, prepared from $0.69 \mathrm{~mL}$ of a $2.5 \mathrm{M}$ solution of $n$-butyllithium $(1.73 \mathrm{mmol})$ in hexanes and $0.24 \mathrm{~mL}(1.73 \mathrm{mmol})$ of diisopropylamine, followed by $1 \mathrm{~mL}$ of HMPA and $1.73 \mathrm{~mL}$ of a $1.0 \mathrm{M}$ solution of TBDMSCl (1.73 mmol) in THF. Hydrolysis with a mixture of $5 \mathrm{~mL}$ of acetic acid and $3 \mathrm{~mL}$ of water provided $0.141 \mathrm{~g}$ of $284\left(0.31 \mathrm{mmol}, 37 \%\right.$ from 276) as a yellow solid: $\mathrm{mp} 230-233{ }^{\circ} \mathrm{C}$; IR 3500-2600 (br), 1708, 756, $703 \mathrm{~cm}^{-1} ;{ }^{1} \mathrm{H} \delta 7.79(1 \mathrm{H}, \mathrm{d}, J=7.4 \mathrm{~Hz}), 7.69(1 \mathrm{H}, \mathrm{d}, J=7.4 \mathrm{~Hz})$, 7.63-7.54 (4 H, m), 7.51-7.46 (1 H, m), 7.42-7.29 (4 H, m), 7.22 (1 H, d, J= 7.7 Hz), 7.10 (1 $\mathrm{H}, \mathrm{t}, J=7.7 \mathrm{~Hz}), 6.72(1 \mathrm{H}, \mathrm{d}, J=7.9 \mathrm{~Hz}), 5.06(1 \mathrm{H}, \mathrm{dd}, J=10.4,1.5 \mathrm{~Hz}), 3.83(1 \mathrm{H}, \mathrm{dd}, J=$ 16.6, $2.5 \mathrm{~Hz}), 3.44-3.26,(4 \mathrm{H}, \mathrm{m}), 2.68(1 \mathrm{H}, \mathrm{dd}, J=16.6,10.6 \mathrm{~Hz}) ;{ }^{13} \mathrm{C} \delta 178.1,146.8,143.7$, $140.8,138.5,138.1,137.8,134.6,134.2,133.0,132.0,131.1,130.0,129.9,129.8,128.9,128.8$, $128.7,128.3,127.9,127.5,126.9,126.0,125.8,124.6,123.7,122.0,42.0,38.6,26.5,26.2 ; \mathrm{MS}$ $m / z 450\left(\mathrm{M}^{+}\right), 404,391$; HRMS calcd for $\mathrm{C}_{33} \mathrm{H}_{22} \mathrm{O}_{2} 450.1620$, found 450.1615. 
Carboxylic Acid 285. The following procedure is representative for the preparation of the carboxylic acids from crude propargylic acetates directly. To a solution of $0.316 \mathrm{~g}(1.56 \mathrm{mmol})$ of 1-(2-ethynylphenyl)-2-phenylethyne in $20 \mathrm{~mL}$ of diethyl ether under a nitrogen atmosphere at $0{ }^{\circ} \mathrm{C}$ was added $0.62 \mathrm{~mL}$ of a $2.5 \mathrm{M}$ solution of $n$-butyllithium $(1.55 \mathrm{mmol})$ in hexanes. The reaction mixture was then allowed to warm to room temperature. After $30 \mathrm{~min}$ at room temperature, a solution of $0.259 \mathrm{~g}(1.42 \mathrm{mmol})$ of benzophenone (277) in $20 \mathrm{~mL}$ of diethyl ether was introduced slowly via cannula. After an additional $2 \mathrm{~h}$ at room temperature, a solution of $0.158 \mathrm{~g}(1.55 \mathrm{mmol})$ of acetic anhydride in $10 \mathrm{~mL}$ of diethyl ether was introduced. After an additional $4 \mathrm{~h}, 20 \mathrm{~mL}$ of water was introduced. The organic layer was separated, and the aqueous layer was back extracted with diethyl ether. The combined organic extracts were washed with brine and water, dried over magnesium sulfate, and concentrated in vacuo. The crude propargylic acetate $\mathbf{2 8 1}$ was used for the next step without further purification.

To a flask containing $1.20 \mathrm{~mL}$ of a $2.5 \mathrm{M}$ solution of $n$-butyllithium $(3.00 \mathrm{mmol})$ in hexanes under a nitrogen atmosphere at $0{ }^{\circ} \mathrm{C}$ were added $0.42 \mathrm{~mL}(3.00 \mathrm{mmol})$ of diisopropylamine and then $2 \mathrm{~mL}$ of THF. After $30 \mathrm{~min}$ at $0{ }^{\circ} \mathrm{C}$, the reaction mixture was cooled to $-78{ }^{\circ} \mathrm{C}$. A solution of the crude propargylic acetate 281 in $15 \mathrm{~mL}$ of THF was introduced slowly via cannula. After $30 \mathrm{~min}$ at $-78{ }^{\circ} \mathrm{C}, 0.8 \mathrm{~mL}$ of $\mathrm{HMPA}$ and $3.0 \mathrm{~mL}$ of a $1.0 \mathrm{M}$ solution of TBDMSCl (3.0 mmol) in THF were introduced. The reaction mixture was allowed to warm to room temperature slowly and then heated at $45{ }^{\circ} \mathrm{C}$. After an additional $12 \mathrm{~h}$ at $45{ }^{\circ} \mathrm{C}$, the reaction mixture was allowed to cool to room temperature. A mixture of $10 \mathrm{~mL}$ of acetic acid and $3.3 \mathrm{~mL}$ of water was introduced. After $12 \mathrm{~h}, 20 \mathrm{~mL}$ of diethyl ether was introduced, and the organic layer was separated. The aqueous layer was back extracted with diethyl ether. The combined organic extracts were washed with water $(5 \times 30 \mathrm{~mL})$, dried over magnesium sulfate, 
and concentrated. Flash column chromatography (silica gel/25\% acetone in hexanes) provided $0.323 \mathrm{~g}$ of 285 (0.76 mmol, $53 \%$ from 277$)$ as a light yellow solid: $\mathrm{mp} 252-255{ }^{\circ} \mathrm{C}$; IR 3500-2600 (br), 1696, 767, $703 \mathrm{~cm}^{-1} ;{ }^{1} \mathrm{H} \delta 7.72-7.35$ (15 H, m), 7.20 (1 H, t, $\left.J=7.4 \mathrm{~Hz}\right), 7.04$ $(1 \mathrm{H}, \mathrm{t}, J=7.5 \mathrm{~Hz}), 6.44(1 \mathrm{H}, \mathrm{d}, J=7.7 \mathrm{~Hz}), 4.69(1 \mathrm{H}, \mathrm{dd}, J=8.9,3.2 \mathrm{~Hz}), 2.75(1 \mathrm{H}, \mathrm{dd}, J=$ 16.6, $3.5 \mathrm{~Hz}), 2.17(1 \mathrm{H}, \mathrm{dd}, J=16.6,9.2 \mathrm{~Hz}) ;{ }^{13} \mathrm{C} \delta 177.2,147.4,141.2,140.4,138.9,138.0$, 136.2, 135.4, 133.34, 133.31, 131.8, 130.9, 130.1, 129.7, 129.5, 129.2, 129.1, 128.4, 127.88, $127.85,127.6,127.3,126.5,125.8,125.52,125.48,124.1,123.8,42.5,37.0 ; \mathrm{MS} m / z 426\left(\mathrm{M}^{+}\right)$, 367; HRMS calcd for $\mathrm{C}_{31} \mathrm{H}_{22} \mathrm{O}_{2} 426.1620$, found 426.1632 .

Compound 286. The same procedure was repeated as described for 285 except that $0.267 \mathrm{~g}$ $(1.28 \mathrm{mmol})$ of benzosuberone (278) was treated with lithium acetylide, derived from $0.276 \mathrm{~g}$ (1.37 mmol) of 1-(2-ethynylphenyl)-2-phenylethyne and $0.54 \mathrm{~mL}$ of a $2.5 \mathrm{M}$ solution of $n$ butyllithium $(1.35 \mathrm{mmol})$ in hexanes, followed by $0.140 \mathrm{~g}(1.37 \mathrm{mmol})$ of acetic anhydride to provide the crude acetate $\mathbf{2 8 2}$. The crude acetate $\mathbf{2 8 2}$ was immediately treated with LDA, derived from $1.00 \mathrm{~mL}$ of a $2.5 \mathrm{M}$ solution of $n$-butyllithium $(2.50 \mathrm{mmol})$ in hexanes and $0.36 \mathrm{~mL}$ (2.57 mmol) of diisopropylamine, followed by $1.0 \mathrm{~mL}$ of HMPA and $2.6 \mathrm{~mL}$ of a $1.0 \mathrm{M}$ solution of TBDMSCl $(2.60 \mathrm{mmol})$ in THF. Hydrolysis with a solution of $10 \mathrm{~mL}$ of $10 \%$ sodium hydroxide, followed by flash column chromatography (silica gel $/ 25 \%$ acetone in hexanes) provided $0.057 \mathrm{~g}$ of $\mathbf{2 8 6}(0.126 \mathrm{mmol}, 10 \%$ from $\mathbf{2 7 8})$ as a yellow solid: $\mathrm{mp} 122-125{ }^{\circ} \mathrm{C}$; IR 1708, 780, 759, $703 \mathrm{~cm}^{-1} ;{ }^{1} \mathrm{H} \delta 7.68-7.12(14 \mathrm{H}, \mathrm{m}), 7.02(1 \mathrm{H}, \mathrm{t}, J=7.4 \mathrm{~Hz}), 6.33(1 \mathrm{H}, \mathrm{d}, J=$ $7.7 \mathrm{~Hz}), 5.07(1 \mathrm{H}, \mathrm{dd}, J=9.0,3.3 \mathrm{~Hz}), 3.50-3.30(3 \mathrm{H}, \mathrm{m}), 3.00-2.80(1 \mathrm{H}, \mathrm{m}), 2.58(1 \mathrm{H}, \mathrm{dd}, J$ $=16.3,3.5 \mathrm{~Hz}), 2.13(1 \mathrm{H}, \mathrm{dd}, J=16.2,9.0 \mathrm{~Hz}) ;{ }^{13} \mathrm{C} \delta 177.0,147.2,143.7,143.6,140.1,139.5$, $139.1,137.8,136.7,134.5,134.3,134.0,132.2,130.5,130.3,129.9,129.3,129.1,128.6,127.84$ $127.77,127.5,127.2,126.7,126.3,125.3,124.5,123.9,123.7,43.9,40.2,36.7,33.6$. 
Ketone 287. The following procedure is representative for the intramolecular acylation reaction. To a flask containing $0.25 \mathrm{~g}(0.59 \mathrm{mmol})$ of 274 under a nitrogen atmosphere was added $5.0 \mathrm{~mL}$ (68.5 mmol) of thionyl chloride. After $3 \mathrm{~h}$ at room temperature, the excess thionyl chloride was removed in vacuo to yield the crude acid chloride (IR $1794 \mathrm{~cm}^{-1}$ ) as a light brown oil. To the solution of the crude acid chloride in $130 \mathrm{~mL}$ of methylene chloride at $0{ }^{\circ} \mathrm{C}$ was added $0.21 \mathrm{~g}$ (1.57 mmol) of anhydrous aluminum chloride. The reaction mixture was allowed to warm to room temperature slowly. After $12 \mathrm{~h}, 10 \mathrm{~mL}$ of a $2 \mathrm{M}$ solution of hydrochloric acid was added, and the organic layer was separated. The aqueous layer was back extracted with methylene chloride. The combined organic layers were washed with saturated aqueous sodium bicarbonate $(3 \times 50 \mathrm{~mL})$ and water, dried over magnesium sulfate, and concentrated. Flash column chromatography (silica gel/50\% methylene chloride in hexanes) furnished $0.21 \mathrm{~g}$ of 287 (0.52 mmol, 88\%) as orange crystals: $\mathrm{mp} 323-325^{\circ} \mathrm{C}$; IR $1662,774,708 \mathrm{~cm}^{-1} ;{ }^{1} \mathrm{H} \delta 8.08(1 \mathrm{H}, \mathrm{d}, J=$ $7.4 \mathrm{~Hz}), 7.97(1 \mathrm{H}, \mathrm{dd}, J=7.7,1.5 \mathrm{~Hz}), 7.94(1 \mathrm{H}, \mathrm{d}, J=7.7 \mathrm{~Hz}), 7.63-7.43(9 \mathrm{H}, \mathrm{m}), 7.33(1 \mathrm{H}$, $\mathrm{t}, J=7.2 \mathrm{~Hz}), 7.14(1 \mathrm{H}, \mathrm{t}, J=7.7 \mathrm{~Hz}), 6.85(1 \mathrm{H}, \mathrm{d}, J=7.7 \mathrm{~Hz}), 4.51(1 \mathrm{H}, \mathrm{d}, J=13.6 \mathrm{~Hz}), 3.64$ $(1 \mathrm{H}, \mathrm{dd}, J=12.9,2.5 \mathrm{~Hz}), 3.24(1 \mathrm{H}, \mathrm{dd}, J=13.6,12.9 \mathrm{~Hz}) ;{ }^{13} \mathrm{C} \delta 199.2,145.9,144.0,141.6$, $139.9,137.9,137.2,135.9,134.7,133.4,130.7,130.4,130.1,129.9,128.9,128.8,128.7,128.1$, $128.0,127.8,127.6,127.5,126.9,126.4,126.1,124.4,123.8,121.3,44.4,41.8 ; \mathrm{MS} m / z 406$ $\left(\mathrm{M}^{+}\right)$, 389, 378; HRMS calcd for $\mathrm{C}_{31} \mathrm{H}_{18} \mathrm{O}$ 406.1358, found 406.1347. Recrystallization of 287 from $\mathrm{CH}_{2} \mathrm{Cl}_{2} / 2$-propanol produced a crystal suitable for X-ray structure analysis (Figure 13).

Ketone 291. The same procedure was repeated as described for 287 except that $0.106 \mathrm{~g}(0.249$ mmol) of 285 was treated with $3 \mathrm{~mL}$ of thionyl chloride and $0.100 \mathrm{~g}(0.749 \mathrm{mmol})$ of anhydrous aluminum chloride to afford $0.071 \mathrm{~g}$ of $291(0.174 \mathrm{mmol}, 70 \%)$ as yellow crystals: $\mathrm{mp} 239-241$ ${ }^{\circ} \mathrm{C}$; IR 1682, 765, $700 \mathrm{~cm}^{-1} ;{ }^{1} \mathrm{H} \delta 8.18(1 \mathrm{H}, \mathrm{dd}, J=7.9,1.5 \mathrm{~Hz}), 7.88(1 \mathrm{H}, \mathrm{dd}, J=7.7,1.2 \mathrm{~Hz})$, 
$7.76(1 \mathrm{H}, \mathrm{dd}, J=7.9,1.0 \mathrm{~Hz}), 7.70-7.38(11 \mathrm{H}, \mathrm{m}), 7.27(1 \mathrm{H}, \mathrm{td}, J=7.4,1.0 \mathrm{~Hz}), 7.08(1 \mathrm{H}, \mathrm{t}$, $J=7.7 \mathrm{~Hz}), 6.52(1 \mathrm{H}, \mathrm{d}, J=7.9 \mathrm{~Hz}), 4.44(1 \mathrm{H}, \mathrm{dd}, J=13.4,4.5 \mathrm{~Hz}), 3.59(1 \mathrm{H}, \mathrm{dd}, J=19.2$, $4.5 \mathrm{~Hz}), 2.69(1 \mathrm{H}, \mathrm{dd}, J=19.2,13.5 \mathrm{~Hz}) ;{ }^{13} \mathrm{C} \delta 204.2,146.2,143.3,140.4,140.1,138.5,135.8$, $134.6,134.4,134.3,131.7,130.9,130.6,130.1,129.8,129.5,129.2,128.0,127.83,127.77$, 127.4, 127.1, 125.9, 125.6, 125.3, 124.0, 123.9, 52.7, 42.0; MS m/z $408\left(\mathrm{M}^{+}\right), 393,378,302$; HRMS calcd for $\mathrm{C}_{31} \mathrm{H}_{20} \mathrm{O}$ 408.1514, found 408.1527. Recrystallization of $\mathbf{2 9 1}$ from $\mathrm{CH}_{2} \mathrm{Cl}_{2} /-$ hexanes produced a crystal suitable for X-ray structure analysis (Figure 14).

Carboxylic Acids 296 and 297. The same procedure was repeated as described for 285 except that $0.162 \mathrm{~g}(1.00 \mathrm{mmol})$ of $\mathbf{2 9 2}$ was treated with $\mathbf{6 0}$, prepared from $0.227 \mathrm{~g}(1.12 \mathrm{mmol})$ of 1-(2ethynylphenyl)-2-phenylethyne and $0.44 \mathrm{~mL}$ of a $2.5 \mathrm{M}$ solution of $n$-butyllithium (1.10 mmol) in hexanes, followed by $0.112 \mathrm{~g}(1.10 \mathrm{mmol})$ of acetic anhydride to provide the crude acetate 293 as a light brown liquid. The crude acetate 293 was treated with LDA, prepared from 0.80 $\mathrm{mL}$ of a $2.5 \mathrm{M}$ solution of $n$-butyllithium $(2.00 \mathrm{mmol})$ in hexanes and $0.28 \mathrm{~mL}(2.00 \mathrm{mmol})$ of diisopropylamine, followed by $1.2 \mathrm{~mL}$ of HMPA and $2.00 \mathrm{~mL}$ of a $1.0 \mathrm{M}$ solution of TBDMSCl (2.00 mmol) in THF. Hydrolysis with a mixture of $7 \mathrm{~mL}$ of acetic acid and $3 \mathrm{~mL}$ of water provided $0.142 \mathrm{~g}$ of $296\left(0.35 \mathrm{mmol}, 35 \%\right.$ from 292) as an orange solid: $\mathrm{mp} 204-206{ }^{\circ} \mathrm{C}$; IR 3500-2600 (br), 1707, 751, $693 \mathrm{~cm}^{-1} ;{ }^{1} \mathrm{H} \delta 7.96(2 \mathrm{H}, \mathrm{d}, J=7.2 \mathrm{~Hz}), 7.67(1 \mathrm{H}, \mathrm{d}, J=7.4 \mathrm{~Hz})$, 7.55-7.10 (11 H, m), $3.85(2 \mathrm{H}, \mathrm{s}), 1.22(9 \mathrm{H}, \mathrm{s}) ;{ }^{13} \mathrm{C} \delta 176.5,153.7,151.7,148.4,147.5,142.8$, $135.5,129.3,129.2,129.0,128.9,128.8,128.6,127.6,126.2,124.0,123.6,120.1,114.8,77.2$ 36.8, 33.2, 29.0; MS $m / z 406\left(\mathrm{M}^{+}\right)$, 360, 349; HRMS calcd for $\mathrm{C}_{29} \mathrm{H}_{26} \mathrm{O}_{2}$ 406.1933, found 406.1915. The formation of $\mathbf{2 9 7}$ was detected in the crude reaction products with ${ }^{1} \mathrm{H}$ NMR signals (partial) at $\delta 8.57(1 \mathrm{H}, \mathrm{d}, J=8.9 \mathrm{~Hz}), 6.96(1 \mathrm{H}, \mathrm{t}, J=6.7 \mathrm{~Hz}), 6.23(1 \mathrm{H}, \mathrm{d}, J=7.7 \mathrm{~Hz})$, $5.41(1 \mathrm{H}, \mathrm{d}, J=11 \mathrm{~Hz}), 3.23(1 \mathrm{H}, \mathrm{d}, J=16 \mathrm{~Hz}), 2.30(1 \mathrm{H}, \mathrm{dd}, J=16,11 \mathrm{~Hz})$. 
Carboxylic Acids $\mathbf{3 0 2}$ and 303. The same procedure was repeated as described for $\mathbf{2 8 5}$ except that $0.571 \mathrm{~g}(3.28 \mathrm{mmol})$ of the ketone $\mathbf{2 9 8}$ was treated with $\mathbf{6 0}$, prepared from $0.800 \mathrm{~g}$ (3.96 mmol) of 1-(2-ethynylphenyl)-2-phenylethyne and $1.57 \mathrm{~mL}$ of a $2.5 \mathrm{M}$ solution of $n$-butyllithium (3.93 mmol) in hexanes, followed by $0.405 \mathrm{~g}(3.96 \mathrm{mmol})$ of acetic anhydride to provide the crude acetate $\mathbf{3 0 0}$ as a light brown liquid. The crude acetate $\mathbf{3 0 0}$ was treated with LDA, prepared from $2.62 \mathrm{~mL}$ of a $2.5 \mathrm{M}$ solution of $n$-butyllithium $(6.55 \mathrm{mmol})$ in hexanes and $0.92 \mathrm{~mL}(6.55$ mmol) of diisopropylamine, followed by $2.0 \mathrm{~mL}$ of HMPA and $6.60 \mathrm{~mL}$ of a $1.0 \mathrm{M}$ solution of TBDMSCl $(6.60 \mathrm{mmol})$ in THF. Hydrolysis with a mixture of $15 \mathrm{~mL}$ of acetic acid and $5 \mathrm{~mL}$ of water provided $0.326 \mathrm{~g}$ of $\mathbf{3 0 2}(0.78 \mathrm{mmol}, 24 \%$ from $\mathbf{2 9 8})$ as an orange solid and $0.326 \mathrm{~g}$ of $\mathbf{3 0 3}$ (0.78 mmol, $24 \%$ from 298 ) as a yellow solid. $\mathbf{3 0 2}$ : $\mathrm{mp} 164-167^{\circ} \mathrm{C}$; IR $3500-2600$ (br), 1702, $726 \mathrm{~cm}^{-1} ;{ }^{1} \mathrm{H} \delta 7.74(1 \mathrm{H}, \mathrm{d}, J=7.4 \mathrm{~Hz}), 7.43-7.08(11 \mathrm{H}, \mathrm{m}), 6.98(1 \mathrm{H}, \mathrm{t}, J=7.4 \mathrm{~Hz}), 3.43(2$ H, s), 3.12-2.98 (2 H, m), 2.04-1.93 (1 H, m), 1.85-1.76 (1 H, m), $1.13(3 \mathrm{H}, \mathrm{s}), 1.03(3 \mathrm{H}, \mathrm{s})$; ${ }^{13} \mathrm{C} \delta 174.9,153.0,152.1,148.1,147.4,138.4,135.0,134.8,129.9,129.4,129.2,128.7,128.5$, 128.4, 126.5, 126.2, 123.7, 123.6, 120.1, 113.1, 68.8, 35.3, 34.7, 31.8, 27.4, 26.2, 26.0. 303: mp 225-228 ${ }^{\circ} \mathrm{C}$; IR 3500-2600 (br), 1708, $732 \mathrm{~cm}^{-1} ;{ }^{1} \mathrm{H} \delta$ 7.61-7.51 (4 H, m), 7.46-7.28 (5 H, m), $7.18(1 \mathrm{H}, \mathrm{td}, J=7.4,0.7 \mathrm{~Hz}), 6.98(1 \mathrm{H}, \mathrm{t}, J=7.7 \mathrm{~Hz}), 6.25(1 \mathrm{H}, \mathrm{d}, J=7.7 \mathrm{~Hz}), 5.21(1 \mathrm{H}, \mathrm{dd}, J$ $=10.6,2.0 \mathrm{~Hz}), 3.57(1 \mathrm{H}, \mathrm{dd}, J=16.7,2.4 \mathrm{~Hz}), 3.46(1 \mathrm{H}, \mathrm{ddd}, J=17.1,11.9,5.2 \mathrm{~Hz}), 3.12(1$ $\mathrm{H}, \mathrm{dt}, J=13.1,4.0 \mathrm{~Hz}), 2.43(1 \mathrm{H}, \mathrm{dd}, J=16.6,10.6 \mathrm{~Hz}), 2.09(1 \mathrm{H}, \mathrm{td}, J=12.5,4.9 \mathrm{~Hz}), 1.94(1$ $\mathrm{H}, \mathrm{dt}, J=12.9,4.5 \mathrm{~Hz}), 1.84(3 \mathrm{H}, \mathrm{s}), 1.59(3 \mathrm{H}, \mathrm{s}) ;{ }^{13} \mathrm{C} \delta 177.0,148.2,139.8,139.6,139.2$, $139.0,136.6,135.4,134.1,133.3,130.2,129.35,129.30,129.0,127.7,127.3,127.2,125.1$, $124.9,124.8,124.0,123.4,44.2,42.6,40.8,36.3,30.7,28.9,27.7$.

Carboxylic Acids 304 and 305. The same procedure was repeated as described for 285 except that $0.522 \mathrm{~g}(3.26 \mathrm{mmol})$ of the ketone $\mathbf{2 9 9}$ was treated with $\mathbf{6 0}$, prepared from $0.806 \mathrm{~g}$ (3.99 
mmol) of 1-(2-ethynylphenyl)-2-phenylethyne and $1.60 \mathrm{~mL}$ of a $2.5 \mathrm{M}$ solution of $n$-butyllithium $(4.00 \mathrm{mmol})$ in hexanes, followed by $0.413 \mathrm{~g}(4.00 \mathrm{mmol})$ of acetic anhydride to provide the crude acetate $\mathbf{3 0 1}$ as a light brown liquid. The crude acetate $\mathbf{3 0 1}$ was treated with LDA, prepared from $2.60 \mathrm{~mL}$ of a $2.5 \mathrm{M}$ solution of $n$-butyllithium $(6.50 \mathrm{mmol})$ in hexanes and $0.91 \mathrm{~mL}(6.49$ mmol) of diisopropylamine, followed by $1.2 \mathrm{~mL}$ of HMPA and $6.50 \mathrm{~mL}$ of a $1.0 \mathrm{M}$ solution of TBDMSCl $(6.50 \mathrm{mmol})$ in THF. Hydrolysis with a mixture of $7 \mathrm{~mL}$ of acetic acid and $3 \mathrm{~mL}$ of water provided $0.132 \mathrm{~g}$ of $304(0.327 \mathrm{mmol}, 10 \%$ from 299) as an orange solid and $0.662 \mathrm{~g}$ of 305 (1.64 mmol, 50\% from 299) as a yellow solid. 304: mp 55-57 ${ }^{\circ} \mathrm{C}$; IR 3500-2600 (br), 1708, $689 \mathrm{~cm}^{-1} ;{ }^{1} \mathrm{H} \delta 7.77(1 \mathrm{H}, \mathrm{d}, J=7.2 \mathrm{~Hz}), 7.40-7.17(10 \mathrm{H}, \mathrm{m}), 7.10-7.06(2 \mathrm{H}, \mathrm{m}), 3.47(2 \mathrm{H}, \mathrm{s})$, $3.21(1 \mathrm{H}, \mathrm{d}, J=16.1 \mathrm{~Hz}), 2.99(1 \mathrm{H}, \mathrm{d}, J=16.1 \mathrm{~Hz}), 1.25(3 \mathrm{H}, \mathrm{s}) ; 1.16(3 \mathrm{H}, \mathrm{s}),{ }^{13} \mathrm{C} \delta 176.3$, $152.8,152.4,147.6,145.8,145.3,141.3,134.4,129.6,129.3,128.8,128.7,127.9,127.8,126.9$, $125.6,124.9,123.8,123.7,120.2,113.6,75.7,47.3,45.4,31.9,28.6,24.7 ; \mathrm{MS} m / z 404\left(\mathrm{M}^{+}\right)$, 389, 359, 345, 329; HRMS calcd for $\mathrm{C}_{29} \mathrm{H}_{24} \mathrm{O}_{2} 404.1776$, found 404.1775. 305: mp 143-146 ${ }^{\circ} \mathrm{C}$; IR 3500-2600 (br), 1708, 779, $703 \mathrm{~cm}^{-1} ;{ }^{1} \mathrm{H} \delta 7.63-7.47(5 \mathrm{H}, \mathrm{m}), 7.40-7.35(2 \mathrm{H}, \mathrm{m})$, 7.30-7.24 (2 H, m), $7.20(1 \mathrm{H}, \mathrm{td}, J=7.4,1.0 \mathrm{~Hz}), 7.02(1 \mathrm{H}, \mathrm{td}, J=7.5,0.9 \mathrm{~Hz}), 6.52(1 \mathrm{H}, \mathrm{d}, J$ $=7.9 \mathrm{~Hz}), 4.83(1 \mathrm{H}, \mathrm{dd}, J=10.3,2.4 \mathrm{~Hz}), 3.57(1 \mathrm{H}, \mathrm{dd}, J=16.6,2.5 \mathrm{~Hz}), 3.41(1 \mathrm{H}, \mathrm{d}, J=16.6$ $\mathrm{Hz}), 3.31(1 \mathrm{H}, \mathrm{d}, J=16.6 \mathrm{~Hz}), 2.59(1 \mathrm{H}, \mathrm{dd}, J=16.6,10.1 \mathrm{~Hz}), 1.76(3 \mathrm{H}, \mathrm{s}), 1.65(3 \mathrm{H}, \mathrm{s}) ;{ }^{13} \mathrm{C}$ $\delta 177.4,148.1,147.0,142.6,140.1,138.64,138.58,137.2,137.0,131.5,131.3,130.3,130.0$ $129.1,128.9,127.7,127.6,127.29,127.26,124.0,123.8,121.6,119.5,49.3,45.2,41.4,41.2$ 30.7, 28.6; MS m/z $404\left(\mathrm{M}^{+}\right), 389,358,345,330,315$; HRMS calcd for $\mathrm{C}_{29} \mathrm{H}_{24} \mathrm{O}_{2}$ 404.1776, found 404.1769 .

Compound 306. To a flask containing $0.183 \mathrm{~g}(0.413 \mathrm{mmol})$ of lead (IV) acetate in $5 \mathrm{~mL}$ of benzene under a nitrogen atmosphere was added a solution of $0.070 \mathrm{~g}(0.172 \mathrm{mmol})$ of $\mathbf{2 8 7}, 0.8$ 
$\mathrm{mL}(6.31 \mathrm{mmol})$ of $\mathrm{BF}_{3} \cdot \mathrm{Et}_{2} \mathrm{O}$, and $1.2 \mathrm{~mL}$ of methanol in $20 \mathrm{~mL}$ of methylene chloride. The reaction mixture was heated under reflux. After $48 \mathrm{~h}, 10 \mathrm{~mL}$ of water was introduced and the organic layer was separated. The aqueous layer was back extracted with methylene chloride. The combined organic extracts were washed with water, dried over magnesium sulfate, and concentrated. Flash column chromatography (silica gel/50\% methylene chloride in hexanes) afforded $0.027 \mathrm{~g}$ of $306(0.062 \mathrm{mmol}, 36 \%)$ as yellow crystals: $\mathrm{mp} 214-216^{\circ} \mathrm{C}$; IR 1686,1060 , $787,669 \mathrm{~cm}^{-1} ;{ }^{1} \mathrm{H} \delta 8.11(1 \mathrm{H}, \mathrm{dd}, J=7.4,0.7 \mathrm{~Hz}), 8.01(1 \mathrm{H}, \mathrm{dd}, J=5.9,1.5 \mathrm{~Hz}), 7.94(1 \mathrm{H}, \mathrm{dd}$, $J=7.9,0.7 \mathrm{~Hz}), 7.68-7.47(9 \mathrm{H}, \mathrm{m}), 7.33(1 \mathrm{H}, \mathrm{td}, J=7.5,1.0 \mathrm{~Hz}), 7.15(1 \mathrm{H}, \mathrm{td}, J=7.7,1.0$ Hz), $6.74(1 \mathrm{H}, \mathrm{d}, J=7.7 \mathrm{~Hz}), 5.70(1 \mathrm{H}, \mathrm{d}, J=10.8 \mathrm{~Hz}), 4.56(1 \mathrm{H}, \mathrm{d}, J=10.8 \mathrm{~Hz}), 2.73(3 \mathrm{H}$, $\mathrm{s}) ;{ }^{13} \mathrm{C} \delta 193.5,143.1,142.0,140.0,137.7,137.0,136.7,136.5,135.3,134.8,132.0,131.6$, $131.2,130.8,130.2,130.1,129.9,129.4,129.0,128.8,128.6,128.5,128.4,126.7,126.4,126.0$, 123.7, 122.0, 83.6, 68.8, 68.2, 50.5. Recrystallization of $\mathbf{3 0 6}$ from $\mathrm{CH}_{2} \mathrm{Cl}_{2} / 2$-propanol produced a crystal suitable for X-ray structure analysis (Figure 15).

Compound 310. To a solution of $0.082 \mathrm{~g}(2.05 \mathrm{mmol})$ of sodium hydride and 1 drops of methanol in $5 \mathrm{~mL}$ of THF under a nitrogen atmosphere at $0{ }^{\circ} \mathrm{C}$ was added a solution of $0.022 \mathrm{~g}$ $(0.054 \mathrm{mmol})$ of $\mathbf{2 8 7}$ and $0.1 \mathrm{~mL}$ of methyl formate in $20 \mathrm{~mL}$ of THF. The reaction mixture was then allowed to warm to room temperature. After $12 \mathrm{~h}$, a solution of $0.332 \mathrm{~g}$ (1.69 mmol) of tosyl azide in $5 \mathrm{~mL}$ THF was introduced into the reaction mixture. After an additional $4 \mathrm{~h}, 5 \mathrm{~mL}$ of water and $30 \mathrm{~mL}$ of methylene chloride were introduced and the organic layer was separated. The aqueous layer was back extracted with methylene chloride. The combined organic extracts were washed with a solution of $10 \% \mathrm{NaOH}$ and water, dried over magnesium sulfate, and concentrated. Flash column chromatography (silica gel $/ 50 \%$ methylene chloride in hexanes) afforded $0.018 \mathrm{~g}$ of $\mathbf{3 1 0}(0.045 \mathrm{mmol}, 83 \%)$ as yellow crystals: $\mathrm{mp} 325-327{ }^{\circ} \mathrm{C}$; IR 1695, 892, 
782, 733, $708 \mathrm{~cm}^{-1} ;{ }^{1} \mathrm{H} \delta 8.43(1 \mathrm{H}, \mathrm{dd}, J=8.2,0.7 \mathrm{~Hz}), 8.21(1 \mathrm{H}, \mathrm{dd}, J=7.2,0.7 \mathrm{~Hz}), 8.01(1$ $\mathrm{H}, \mathrm{dd}, J=6.3,1.1 \mathrm{~Hz}), 7.95(1 \mathrm{H}, \mathrm{d}, J=7.2 \mathrm{~Hz}), 7.74-7.55(9 \mathrm{H}, \mathrm{m}), 7.37(1 \mathrm{H}, \mathrm{td}, J=7.5,1.0$ $\mathrm{Hz}), 7.26(1 \mathrm{H}, \mathrm{m}), 6.90(1 \mathrm{H}, \mathrm{d}, J=7.7 \mathrm{~Hz})$. Recrystallization of $\mathbf{3 1 0}$ from $\mathrm{CH}_{2} \mathrm{Cl}_{2}$ /2-propanol produced a crystal suitable for X-ray structure analysis (Figure 16).

Fluorenylmethanol 370. To a solution of $0.317 \mathrm{~g}(0.796 \mathrm{mmol})$ of hydrocarbon $369 \mathrm{in} 8 \mathrm{~mL}$ of THF under a nitrogen atmosphere at $0{ }^{\circ} \mathrm{C}$ was added $0.53 \mathrm{~mL}$ of a $2.0 \mathrm{M}$ solution of LDA (1.06 $\mathrm{mmol})$ in heptane/tetrahydrofuran/ethylbenzene. After $10 \mathrm{~min}$ at $0{ }^{\circ} \mathrm{C}, 0.030 \mathrm{~g}(1.00 \mathrm{mmol})$ of paraformaldehyde was transferred into the reaction mixture via a solid addition tube. The reaction mixture was then allowed to warm to room temperature. After an additional 15 min, 5 $\mathrm{mL}$ of saturated sodium bicarbonate solution was introduced and the reaction mixture was extracted with diethyl ether. The combined organic extracts were washed with brine and water, dried over magnesium sulfate, and concentrated. Flash column chromatography (silica gel/20\% diethyl ether in hexanes) afforded $0.311 \mathrm{~g}$ of $\mathbf{3 7 0}(0.727 \mathrm{mmol}, 91 \%)$ as a white solid: $\mathrm{mp}$ 207-209 ${ }^{\circ} \mathrm{C}$; IR 3401 (br), 832, 750, $697 \mathrm{~cm}^{-1} ;{ }^{1} \mathrm{H} \delta 8.50(1 \mathrm{H}, \mathrm{d}, J=9.6 \mathrm{~Hz}), 7.79(1 \mathrm{H}, \mathrm{dd}, J=$ 7.9, $1.5 \mathrm{~Hz}), 7.68-7.52(7 \mathrm{H}, \mathrm{m}), 7.41-7.31(2 \mathrm{H}, \mathrm{m}), 7.21(1 \mathrm{H}, \mathrm{td}, J=7.4,1.0 \mathrm{~Hz}), 7.04-6.93$ $(2 \mathrm{H}, \mathrm{m}), 5.94(1 \mathrm{H}, \mathrm{d}, J=7.9 \mathrm{~Hz}), 5.02(1 \mathrm{H}, \mathrm{dd}, J=7.5,3.8 \mathrm{~Hz}), 4.45-4.41(1 \mathrm{H}, \mathrm{m})$, 3.56-3.45 (1 H, m), $1.91(9 \mathrm{H}, \mathrm{s}) ;{ }^{13} \mathrm{C} \delta 146.3,143.3,142.9,140.8,139.9,139.4,134.2,132.8$, $132.5,131.4,130.2,130.0,129.9,128.7,127.9,127.6,126.9,126.8,126.2,125.6,124.5,124.3$, 124.2, 123.6, 67.8, 51.4, 38.5, 34.6; MS m/z $429\left(\mathrm{MH}^{+}\right), 415,355,281,207$.

Hydrocarbon 371. To a flask containing $0.069 \mathrm{~g}(0.161 \mathrm{mmol})$ of $\mathbf{3 7 0}$ was added $0.256 \mathrm{~g}(1.80$ mmol) of phosphorus pentoxide, followed by $10 \mathrm{~mL}$ of $p$-xylene via cannula. The reaction mixture was heated under reflux for $2 \mathrm{~h}$. After the reaction mixture cooled to room temperature, $10 \mathrm{~mL}$ of saturated sodium bicarbonate solution was introduced and the organic layer was 
separated. The aqueous layer was back extracted with diethyl ether. The combined organic extracts were washed with water $(3 \times 30 \mathrm{~mL})$, dried over magnesium sulfate, and concentrated. Flash column chromatography (silica gel $/ 10 \%$ methylene chloride in hexanes) provided $0.050 \mathrm{~g}$ of $371(0.141 \mathrm{mmol}, 88 \%)$ as a white solid: $\mathrm{mp} 259-261^{\circ} \mathrm{C}$; IR 1443, 878, 790, 743, $696 \mathrm{~cm}^{-1}$; ${ }^{1} \mathrm{H} \delta 8.35(1 \mathrm{H}, \mathrm{s}), 7.82(2 \mathrm{H}, \mathrm{d}, J=8.9 \mathrm{~Hz}), 7.79(2 \mathrm{H}, \mathrm{dd}, J=8.2,1.5 \mathrm{~Hz}), 7.69(2 \mathrm{H}, \mathrm{d}, J=8.7$ Hz), 7.66-7.58 (3 H, m), 7.52-7.48 (2 H, m), $7.39(2 \mathrm{H}, \mathrm{td}, J=7.9,1.0 \mathrm{~Hz}), 7.21(2 \mathrm{H}, \mathrm{d}, J=8.7$ $\mathrm{Hz}), 6.99(2 \mathrm{H}, \mathrm{td}, J=8.7,1.7 \mathrm{~Hz}) ;{ }^{13} \mathrm{C} \delta 145.4,138.8,134.2,131.5,131.3,131.2,130.6,129.0$, 128.4, 128.2, 128.13, 128.10, 127.8, 126.9, 125.9, 124.5; MS m/z $354\left(\mathrm{M}^{+}\right), 337,313$; HRMS: calcd for $\mathrm{C}_{28} \mathrm{H}_{18}, 354.1409$; found, 354.1402 .

Diol 376. The following procedure is representative for the preparation of the diols. To a solution of $0.344 \mathrm{~g}(0.557 \mathrm{mmol})$ of hydrocarbon $78 \mathrm{a}$ in $60 \mathrm{~mL}$ of benzene and $50 \mathrm{~mL}$ of THF under a nitrogen atmosphere at $0{ }^{\circ} \mathrm{C}$ was added $1.80 \mathrm{~mL}$ of a $2.0 \mathrm{M}$ solution of LDA (3.60 mmol $)$ in heptane/tetrahydrofuran/ethylbenzene. After $20 \mathrm{~min}$ at $0{ }^{\circ} \mathrm{C}, 0.220 \mathrm{~g}(7.33 \mathrm{mmol})$ of paraformaldehyde was transferred into the reaction mixture via a solid addition tube. The reaction mixture was allowed to warm to room temperature. After an additional $30 \mathrm{~min}, 10 \mathrm{~mL}$ of saturated sodium bicarbonate solution was introduced and the reaction mixture was extracted with diethyl ether. The combined organic extracts were washed with brine and water, dried over magnesium sulfate, and concentrated. Flash column chromatography (silica gel $/ 50 \%$ diethyl ether in hexanes) afforded $0.287 \mathrm{~g}$ of $\mathbf{3 7 6}(0.423 \mathrm{mmol}, 76 \%$, a mixture of three isomers, isomer ratio $=22: 12: 1)$ as an orange solid: $\mathrm{mp} 221-225{ }^{\circ} \mathrm{C}$; IR $3412(\mathrm{br}), 765,704 \mathrm{~cm}^{-1} ;{ }^{1} \mathrm{H} \delta$ isomer 1 : $7.86(2 \mathrm{H}, \mathrm{s}), 7.49(2 \mathrm{H}, \mathrm{d}, J=7.4 \mathrm{~Hz}), 7.21-6.96(8 \mathrm{H}, \mathrm{m}), 6.80(2 \mathrm{H}, \mathrm{t}, J=7.7 \mathrm{~Hz}), 6.53-6.50$ (4 H, m), $6.27(2 \mathrm{H}, \mathrm{d}, J=7.9 \mathrm{~Hz}), 4.76-4.69(2 \mathrm{H}, \mathrm{m}), 4.47(2 \mathrm{H}, \mathrm{d}, J=10.6 \mathrm{~Hz}), 3.82(1.5 \mathrm{H}$, dd, $J=10.6,6.4 \mathrm{~Hz}), 3.72(0.5 \mathrm{H}, \mathrm{dd}, J=10.8,5.5 \mathrm{~Hz}), 1.85(18 \mathrm{H}, \mathrm{s})$; isomer 2 (partial of 
signals): $8.02(1 \mathrm{H}, \mathrm{d}, J=9.7 \mathrm{~Hz}), 7.92(1 \mathrm{H}, \mathrm{d}, J=9.4 \mathrm{~Hz}), 7.47(2 \mathrm{H}, \mathrm{d}, J=7.4 \mathrm{~Hz}), 6.38(1 \mathrm{H}$, d, $J=7.4 \mathrm{~Hz}), 6.36(1 \mathrm{H}, \mathrm{d}, J=7.7 \mathrm{~Hz}), 4.87(2 \mathrm{H}, \mathrm{dd}, J=7.9,3.7 \mathrm{~Hz}), 4.38(2 \mathrm{H}, \mathrm{dd}, J=10.9$, $3.5 \mathrm{~Hz}), 3.48(1 \mathrm{H}, \mathrm{dd}, J=10.4,8.2 \mathrm{~Hz}), 1.90(9 \mathrm{H}, \mathrm{s}), 1.88(9 \mathrm{H}, \mathrm{s})$; isomer 3 (partial of signals): $8.09(2 \mathrm{H}, \mathrm{s}), 1.93(9 \mathrm{H}, \mathrm{s}) ;{ }^{13} \mathrm{C} \delta$ ( 3 isomers) $146.7,146.6,140.8,140.7,140.6,140.5,140.4$, 139.0, 138.8, 138.7, 138.4, 138.3, 137.4, 137.2, 135.9, 135.5, 135.4, 135.1, 135.0, 134.9, 134.8, $134.6,133.3,132.5,132.2,132.1,131.2,131.1,128.2,127.7,127.2,126.92,126.88,126.55$ $126.52,126.1,126.0,123.8,123.5,123.3,123.0,122.9,122.1,121.9,69.5,67.1,67.0,52.2,50.6$, 38.2, 37.8, 37.7, 34.5, 34.3, 34.2; MS $m / z 678\left(\mathrm{M}^{+}\right), 664,647,605$; HRMS: calcd for $\mathrm{C}_{50} \mathrm{H}_{46} \mathrm{O}_{2}$, 678.3492; found, 678.3496 .

Hydrocarbon 377. The following procedure is representative for the preparation of the hydrocarbons only via ring expansion. To a flask containing $0.0134 \mathrm{~g}$ of $(0.0198 \mathrm{mmol})$ diol 376 was added $0.100 \mathrm{~g}(0.704 \mathrm{mmol})$ of phosphorus pentoxide, followed by $10 \mathrm{~mL}$ of $p$-xylene via cannula. The reaction mixture was heated at $110{ }^{\circ} \mathrm{C}$ for $10 \mathrm{~min}$. After the reaction mixture cooled to room temperature, $10 \mathrm{~mL}$ of saturated sodium bicarbonate solution was introduced. The organic layer was separated. The aqueous layer was back extracted with diethyl ether. The combined organic extracts were washed with water $(3 \times 30 \mathrm{~mL})$, dried over magnesium sulfate, and concentrated. Flash column chromatography (silica gel/10\% methylene chloride in hexanes) provided $0.0076 \mathrm{~g}$ of $377(0.0143 \mathrm{mmol}, 72 \%)$ as a light yellow solid: $\mathrm{mp} 272-275^{\circ} \mathrm{C}$; IR 1437 , 879, 797, 744, $697 \mathrm{~cm}^{-1}$; ${ }^{1} \mathrm{H} \delta 8.03(2 \mathrm{H}, \mathrm{s}), 7.71(2 \mathrm{H}, \mathrm{d}, J=8.9 \mathrm{~Hz}), 7.65(2 \mathrm{H}, \mathrm{d}, J=7.7 \mathrm{~Hz})$, $7.61(2 \mathrm{H}, \mathrm{d}, J=8.9 \mathrm{~Hz}), 7.44(2 \mathrm{H}, \mathrm{s}), 7.19(2 \mathrm{H}, \mathrm{td}, J=7.9,1.0 \mathrm{~Hz}), 7.00(2 \mathrm{H}, \mathrm{tt}, J=7.4,1.0$ $\mathrm{Hz}), 6.81(4 \mathrm{H}, \mathrm{t}, J=7.7 \mathrm{~Hz}), 6.62(2 \mathrm{H}, \mathrm{td}, J=7.8,1.5 \mathrm{~Hz}), 6.51(2 \mathrm{H}, \mathrm{d}, J=8.7 \mathrm{~Hz}), 6.40(4 \mathrm{H}$, $\mathrm{dd}, J=8.0,1.1 \mathrm{~Hz}) ;{ }^{13} \mathrm{C} \delta 141.2,139.3,133.9,132.52,132.45,132.3,130.9,128.90,128.85$, 
128.2, 127.7, 127.2, 127.0, 126.4, 126.0, 125.5, 123.6, 122.8; MS m/z $530\left(\mathrm{M}^{+}\right), 453,437,424$ HRMS: calcd for $\mathrm{C}_{42} \mathrm{H}_{26}, 530.2035$; found, 530.2035 .

Hydrocarbon 378. To a flask containing $0.083 \mathrm{~g}(0.122 \mathrm{mmol})$ of diol 376 was added $0.310 \mathrm{~g}$ (2.18 mmol) of phosphorus pentoxide, followed by $15 \mathrm{~mL}$ of $p$-xylene via cannula. The reaction mixture was heated under reflux for $1.5 \mathrm{~h}$. After the reaction mixture cooled to room temperature, $10 \mathrm{~mL}$ of saturated sodium bicarbonate solution was introduced and the organic layer was separated. The aqueous layer was back extracted with diethyl ether. The combined organic extracts were washed with water $(3 \times 30 \mathrm{~mL})$, dried over magnesium sulfate, and concentrated. Crystallization of the crude product from hexanes provided $0.050 \mathrm{~g}$ of $\mathbf{3 7 8}(0.094$ mmol, 77\%) as a bright yellow solid: $\mathrm{mp} 260-262{ }^{\circ} \mathrm{C}$; IR $1443,873,738,703 \mathrm{~cm}^{-1} ;{ }^{1} \mathrm{H} \delta 9.50(1$ H, dd, $J=6.4,3.5 \mathrm{~Hz}), 8.31(2 \mathrm{H}, \mathrm{d}, J=8.2 \mathrm{~Hz}), 8.12(1 \mathrm{H}, \mathrm{s}), 7.90-7.70(6 \mathrm{H}, \mathrm{m}), 7.64-7.58(3$ H, m), $7.45(1 \mathrm{H}, \mathrm{d}, J=8.4 \mathrm{~Hz}), 7.36(1 \mathrm{H}, \mathrm{td}, J=7.1,1.0 \mathrm{~Hz}), 7.31-7.22(3 \mathrm{H}, \mathrm{m}), 7.06-6.92(3$ $\mathrm{H}, \mathrm{m}), 6.61(3 \mathrm{H}, \mathrm{s}), 4.83(1 \mathrm{H}, \mathrm{d}, J=22.8 \mathrm{~Hz}), 4.77(1 \mathrm{H}, \mathrm{d}, J=23.0 \mathrm{~Hz}) ;{ }^{13} \mathrm{C} \delta 149.1,139.5$, $136.1,133.7,133.3,133.0,132.4,131.9,131.8,130.5,130.4,130.1,129.3,129.2,128.72$ $128.65,128.4,128.2,127.9,127.63,127.58,127.0,126.9,126.3,126.2,125.7,125.6,125.2$, 125.1, 124.6, 53.4, 35.8; MS $m / z 530\left(\mathrm{M}^{+}\right), 453,435,424$; HRMS: calcd for $\mathrm{C}_{42} \mathrm{H}_{26}, 530.2035$; found, 530.2030 .

Hydrocarbon 379. The following procedure is representative for the preparation of the butterfly-shaped hydrocarbons. To a flask containing $0.048 \mathrm{~g}(0.071 \mathrm{mmol})$ of diol 376 was added $0.496 \mathrm{~g}(3.49 \mathrm{mmol})$ of phosphorus pentoxide, followed by $20 \mathrm{~mL}$ of $p$-xylene via cannula. The reaction mixture was heated under reflux for $12 \mathrm{~h}$. After the reaction mixture cooled to room temperature, $10 \mathrm{~mL}$ of saturated sodium bicarbonate solution was introduced and the organic layer was separated. The aqueous layer was back extracted with diethyl ether. The 
combined organic extracts were washed with water $(3 \times 30 \mathrm{~mL})$, dried over magnesium sulfate, and concentrated. Crystallization of the crude product from hexanes provided $0.033 \mathrm{~g}$ of $\mathbf{3 7 9}$ (0.062 mmol, 87\%) as a light brown solid: $\mathrm{mp}>380^{\circ} \mathrm{C}$; IR 1455, 797, 779, $744 \mathrm{~cm}^{-1} ;{ }^{1} \mathrm{H} \delta 8.02$ $(2 \mathrm{H}, \mathrm{d}, J=8.2 \mathrm{~Hz}), 7.99(2 \mathrm{H}, \mathrm{d}, J=8.7 \mathrm{~Hz}), 7.75(2 \mathrm{H}, \mathrm{d}, J=8.4 \mathrm{~Hz}), 7.60(2 \mathrm{H}, \mathrm{d}, J=8.4 \mathrm{~Hz})$, $7.49(2 \mathrm{H}, \mathrm{td}, J=7.7,0.9 \mathrm{~Hz}), 7.31-7.24(2 \mathrm{H}, \mathrm{m}), 6.85(2 \mathrm{H}, \mathrm{s}), 6.79-6.71(8 \mathrm{H}, \mathrm{m}), 4.42(4 \mathrm{H}$, s); ${ }^{13} \mathrm{C} \delta 146.0,141.1,139.9,134.8,133.4,132.5,130.5,128.8,128.6,128.2,126.7,125.6$, 124.9, 124.7, 124.1, 123.7, 54.1, 33.8; MS $m / z$ 530, 453, 424. HRMS: calcd for $\mathrm{C}_{42} \mathrm{H}_{26}$, 530.2035; found, 530.2025 .

Diketone 380. To a flask containing $0.021 \mathrm{~g}(0.040 \mathrm{mmol})$ of hydrocarbon 379 was added 0.101 $\mathrm{g}(0.445 \mathrm{mmol})$ of DDQ, followed by $25 \mathrm{~mL}$ of benzene. The reaction mixture was heated under reflux for $72 \mathrm{~h}$. After the reaction mixture cooled to room temperature, it was run through an aluminum oxide column, followed by diethyl ether to rinse the column. The combined organic solution was concentrated. Flash column chromatography (silica gel/10\% diethyl ether in hexanes) provided $0.017 \mathrm{~g}$ of $\mathbf{3 8 0}(0.030 \mathrm{mmol}, 75 \%)$ as a light yellow solid: $\mathrm{mp}>370{ }^{\circ} \mathrm{C}$; IR $1654,878,758 \mathrm{~cm}^{-1} ;{ }^{1} \mathrm{H} \delta 8.82(2 \mathrm{H}, \mathrm{d}, J=8.7 \mathrm{~Hz}), 8.31(2 \mathrm{H}, \mathrm{d}, J=8.9 \mathrm{~Hz}), 8.17(2 \mathrm{H}, \mathrm{d}, J=$ $8.2 \mathrm{~Hz}), 8.12(2 \mathrm{H}, \mathrm{s}), 7.88(2 \mathrm{H}, \mathrm{d}, J=8.7 \mathrm{~Hz}), 7.74(2 \mathrm{H}, \mathrm{td}, J=8.0,1.2 \mathrm{~Hz}), 7.45(2 \mathrm{H}, \mathrm{td}, J=$ 8.4, 1.2 Hz), 6.86-6.82 (4 H, m), 6.75-6.70 (4 H, m); ${ }^{13} \mathrm{C} \delta 182.6,150.8,143.6,136.7,136.5$, $132.5,131.7,131.4,130.3,129.9,129.2,128.5,125.79,125.75,125.70,124.5,122.9,53.3 ;$ MS $m / z 558\left(\mathrm{M}^{+}\right), 529,498,479,464$. HRMS: calcd for $\mathrm{C}_{42} \mathrm{H}_{22} \mathrm{O}_{2}, 558.1620$; found, 558.1603. Recrystallization of $\mathbf{3 8 0}$ from $\mathrm{CH}_{2} \mathrm{Cl}_{2} / 2$-propanol produced a crystal suitable for X-ray structure analysis (Figure 17).

Diol 385a. The same procedure was repeated as described for 376 except that $0.094 \mathrm{~g}(0.122$ mmol) of 78b in a mixture of $30 \mathrm{~mL}$ of benzene and $20 \mathrm{~mL}$ of THF was treated with $0.50 \mathrm{~mL}$ of 
a $2.0 \mathrm{M}$ solution of LDA $(1.0 \mathrm{mmol})$ in heptane/tetrahydrofuran/-ethylbenzene, followed by $0.050 \mathrm{~g}(1.67 \mathrm{mmol})$ of paraformaldehyde to afford $0.078 \mathrm{~g}$ of $\mathbf{3 8 5 a}(0.094 \mathrm{mmol}, 77 \%$, a mixture of two isomers, isomer ratio $=1: 1.2)$ as a bright yellow solid: $\mathrm{mp} 235-238^{\circ} \mathrm{C}$; IR 3416 (br), 906, 840, 768, 728, $696 \mathrm{~cm}^{-1}$; ${ }^{1} \mathrm{H} \delta$ : isomer 1: $7.85(2 \mathrm{H}, \mathrm{s}), 7.68-7.62(4 \mathrm{H}, \mathrm{m}), 7.51-7.25$ $(12 \mathrm{H}, \mathrm{m}), 7.03(2 \mathrm{H}, \mathrm{td}, J=7.4,1.0 \mathrm{~Hz}), 6.80-6.74(2 \mathrm{H}, \mathrm{m}), 6.62-6.58(4 \mathrm{H}, \mathrm{m}), 6.36(2 \mathrm{H}, \mathrm{d}, J$ = 7.9 Hz), 4.87-4.72 (2 H, m), 4.51-4.38 (2 H, m), 3.90-3.44 (2 H, m), $1.84(18 \mathrm{H}, \mathrm{s})$; isomer 2 (partial of signals): $8.00(1 \mathrm{H}, \mathrm{d}, J=9.4 \mathrm{~Hz}), 7.90(1 \mathrm{H}, \mathrm{d}, J=9.4 \mathrm{~Hz}), 7.10(2 \mathrm{H}, \mathrm{t}, J=7.4 \mathrm{~Hz})$, $6.45(1 \mathrm{H}, \mathrm{d}, J=8.2 \mathrm{~Hz}), 6.41(1 \mathrm{H}, \mathrm{d}, J=8.2 \mathrm{~Hz}), 1.88(9 \mathrm{H}, \mathrm{s}), 1.87(9 \mathrm{H}, \mathrm{s}) ;{ }^{13} \mathrm{C} \delta(2$ isomers $)$ 146.8, 146.6, 141.11, 141.08, 141.00, 140.8, 140.73, 140.67, 140.6, 140.5, 140.4, 139.3, 139.15, 139.08, 138.91, 138.87, 137.9, 137.7, 137.56, 137.53, 137.4, 136.1, 134.9, 134.6, 134.5, 134.3, 133.0, 132.6, 132.2, 132.0, 131.2, 131.0, 128.85, 128.76, 127.32, 127.28, 127.23, 126.8, 126.7, $126.6,126.4,126.2,126.1,126.0,123.9,123.6,123.3,123.0,122.9,122.8,122.3,122.0,69.6$, 67.1, 66.9, 52.3, 50.7, 38.3, 37.8, 37.7, 34.5, 34.3, 34.2; MS m/z $830\left(\mathrm{M}^{+}\right), 799,681,656$. HRMS: calcd for $\mathrm{C}_{62} \mathrm{H}_{54} \mathrm{O}_{2}, 830.4118$; found, 830.4073 .

Hydrocarbon 386a. The same procedure was repeated as described for $\mathbf{3 7 7}$ except that 0.0085 $\mathrm{g}(0.0102 \mathrm{mmol})$ of $\mathbf{3 8 5 a}$ and $0.100 \mathrm{~g}(0.704 \mathrm{mmol})$ of phosphorus pentoxide, followed by 10 $\mathrm{mL}$ of benzene at $90{ }^{\circ} \mathrm{C}$ for $15 \mathrm{~min}$ to afford $0.0062 \mathrm{~g}$ of $\mathbf{3 8 6 a}(0.0091 \mathrm{mmol}, 89 \%)$ as a yellow solid: mp 264-267 ${ }^{\circ} \mathrm{C}$; IR 1449, 803, 732, $697 \mathrm{~cm}^{-1} ;{ }^{1} \mathrm{H} \delta 8.06(2 \mathrm{H}, \mathrm{s}), 7.73(2 \mathrm{H}, \mathrm{d}, J=8.7 \mathrm{~Hz})$, 7.65-7.54 (8 H, m), $7.47(2 \mathrm{H}, \mathrm{s}), 7.40(4 \mathrm{H}, \mathrm{td}, J=7.3,1.2 \mathrm{~Hz}), 7.33-7.26(2 \mathrm{H}, \mathrm{m}), 7.17(2 \mathrm{H}$, $\mathrm{tt}, J=7.9,1.3 \mathrm{~Hz}), 7.12(4 \mathrm{H}, \mathrm{d}, J=8.4 \mathrm{~Hz}), 6.68-6.59(4 \mathrm{H}, \mathrm{m}), 6.54(4 \mathrm{H}, \mathrm{d}, J=8.2 \mathrm{~Hz}) ;{ }^{13} \mathrm{C} \delta$ $140.7,140.5,138.8,138.6,134.0,132.7,132.5,132.4,130.9,129.0,128.7,128.1,127.9,127.5$ 127.3, 127.2, 127.1, 126.7, 126.5, 125.9, 125.6, 123.9, 122.9; MS m/z $682\left(\mathrm{M}^{+}\right), 528,448,425$. HRMS: calcd for $\mathrm{C}_{54} \mathrm{H}_{34}, 682.2661$; found, 682.2687 . 
Hydrocarbon 387. The same procedure was repeated as described for 379 except that $0.038 \mathrm{~g}$ $(0.046 \mathrm{mmol})$ of 385a and $0.300 \mathrm{~g}(2.11 \mathrm{mmol})$ of phosphorus pentoxide, followed by $40 \mathrm{~mL}$ of $p$-xylene under reflux for $12 \mathrm{~h}$ to afford $0.013 \mathrm{~g}$ of $\mathbf{3 8 7}(0.019 \mathrm{mmol}, 41 \%)$ as a yellow solid: $\mathrm{mp}$ 186-189 ${ }^{\circ} \mathrm{C}$; IR 908, 756, 732, $697 \mathrm{~cm}^{-1} ;{ }^{1} \mathrm{H}(270 \mathrm{MHz}) \mathrm{NMR} \delta 8.035(2 \mathrm{H}, \mathrm{d}, J=8.4 \mathrm{~Hz})$, $8.026(2 \mathrm{H}, \mathrm{d}, J=7.9 \mathrm{~Hz}), 7.89(2 \mathrm{H}, \mathrm{d}, J=8.4 \mathrm{~Hz}), 7.61(2 \mathrm{H}, \mathrm{d}, J=8.4 \mathrm{~Hz}), 7.54(2 \mathrm{H}, \mathrm{td}, J=$ 7.9, $1.0 \mathrm{~Hz}), 7.35(2 \mathrm{H}, \mathrm{td}, J=8.4,1.5 \mathrm{~Hz}), 7.22-7.10(6 \mathrm{H}, \mathrm{m}), 7.04-6.96(8 \mathrm{H}, \mathrm{m}), 6.89(2 \mathrm{H}$, s), $6.86(2 \mathrm{H}, \mathrm{d}, J=8.7 \mathrm{~Hz}), 4.44(4 \mathrm{H}, \mathrm{s}) ;{ }^{1} \mathrm{H}(600 \mathrm{MHz}) \mathrm{NMR} \delta$ (partial signals) $4.46(2 \mathrm{H}, \mathrm{d}, J$ $=21.6 \mathrm{~Hz}), 4.43(2 \mathrm{H}, \mathrm{d}, J=22.2 \mathrm{~Hz}) ;{ }^{13} \mathrm{C} \mathrm{NMR} \delta 146.6,145.3,142.2,140.9,137.1,134.9$, $133.5,132.5,130.4,129.0,128.8,128.4,128.2,127.1,126.9,126.8,126.7,126.4,125.9,125.1$, 124.7, 124.1, 123.1, 54.0, 33.8; MS $m / z 682\left(\mathrm{M}^{+}\right), 529,425$. HRMS: calcd for $\mathrm{C}_{54} \mathrm{H}_{34}, 682.2661$; found, 682.2663 .

Diol 385b. The same procedure was repeated as described for $\mathbf{3 7 6}$ except that $0.065 \mathrm{~g}(0.091$ mmol) of 384 in $45 \mathrm{~mL}$ of THF was treated with $0.50 \mathrm{~mL}$ of a $2.0 \mathrm{M}$ solution of LDA (1.0 $\mathrm{mmol})$ in heptane/tetrahydrofuran/ethylbenzene, followed by $0.10 \mathrm{~g}(3.3 \mathrm{mmol})$ of paraformaldehyde to afford $0.054 \mathrm{~g}$ of $\mathbf{3 8 5 \mathbf { b }}(0.069 \mathrm{mmol}, 76 \%$, a mixture of several isomers $)$ as an orange solid: mp $243-246{ }^{\circ} \mathrm{C}$; IR 3413 (br), 908, 803, 779, $732 \mathrm{~cm}^{-1} ;{ }^{1} \mathrm{H}$ 8: 8.22-7.90 (2 H, m), 7.84-7.66 (2 H, m), 7.63-5.80 (18 H, m), 5.71-4.82 (2 H, d, J=8.2 Hz), 4.82-4.40 (3 H, m), 3.90-2.97 (3 H, m), 1.94-1.86 (18 H, m); ${ }^{13} \mathrm{C} \delta$ (isomers) 146.6, 146.52, 146.49, 146.3, $146.2,145.8,145.7,141.2,140.80,140.77,140.68,140.6,140.53,140.49,140.4,140.3,140.0$, $139.8,139.3,139.2,139.1,139.03,138.96,138.8,138.6,138.3,138.2,138.1,138.0,137.7$, 137.6, 136.6, 136.1, 135.8, 135.4, 135.1, 134.8, 134.7, 134.5, 134.4, 134.1, 134.0, 133.9, 133.8, 133.7, 133.6, 133.5, 133.4, 133.31, 133.25, 133.00, 132.97, 132.7, 132.5, 132.4, 132.2, 131.8, $131.6,128.6,128.5,128.2,128.1,128.0,127.93,127.88,127.81,127.74,127.68,127.63,127.4$, 
$127.3,127.1,126.9,126.6,126.5,126.3,126.2,126.1,126.00,125.95,125.85,125.79,125.73$, $125.64,125.59,125.5,125.4,125.12,125.07,124.98,124.95,124.8,124.74,124.67,124.61$, $124.60,124.53,124.42,124.36,124.3,124.0,123.9,123.8,123.4,123.2,123.13,123.06,122.9$, $122.74,122.65,122.2,122.1,121.8,69.6,69.54,69.50,69.1,67.1,66.9,66.8,66.7,66.5,52.4$, $52.31,52.25,52.18,52.13,51.9,51.7,50.7,50.55,50.51,38.35,38.29,37.9,37.82,38.78,37.7$, 37.6, 34.6, 34.4, 34.3, 34.23, 34.18; MS $m / z 778\left(\mathrm{M}^{+}\right), 764,747,691,655$. HRMS: calcd for $\mathrm{C}_{58} \mathrm{H}_{50} \mathrm{O}_{2}, 778.3805$; found, 778.3833 .

Hydrocarbon 386b. The same procedure was repeated as described for $\mathbf{3 7 7}$ except that 0.0061 $\mathrm{g}(0.0078 \mathrm{mmol})$ of diol and $0.100 \mathrm{~g}(0.704 \mathrm{mmol})$ of phosphorus pentoxide, followed by $15 \mathrm{~mL}$ of benzene at $90{ }^{\circ} \mathrm{C}$ for $15 \mathrm{~min}$ to afford $0.0047 \mathrm{~g}$ of $\mathbf{3 8 6 \mathbf { b }}(0.0075 \mathrm{mmol}, 96 \%$, a mixture of three isomers, isomer ratio $=7: 2: 1)$ as a yellow solid: $\mathrm{mp} 189-192{ }^{\circ} \mathrm{C}$; IR $882,799,776,746$, $723 \mathrm{~cm}^{-1} ;{ }^{1} \mathrm{H} \delta$ : isomer 1: $8.19(1 \mathrm{H}, \mathrm{s}), 8.10(1 \mathrm{H}, \mathrm{s}), 7.80-7.75(1 \mathrm{H}, \mathrm{m}), 7.65-7.36(11 \mathrm{H}, \mathrm{m})$, 7.15-6.65 (10 H, m), 6.39-6.16 (1 H, m), 6.08-5.87 (2 H, m), 5.83-5.74 (1 H, m), 5.56-5.47 (2 $\mathrm{H}, \mathrm{m}$ ); isomer 2 (partial): $8.17(2 \mathrm{H}, \mathrm{s})$; isomer 3 (partial): $8.08(2 \mathrm{H}, \mathrm{s}) ;{ }^{13} \mathrm{C} \delta$ (3 isomers) 137.6, $133.9,133.62,133.55,133.4,132.8,132.7,132.5,132.2,132.0,131.5,130.9,130.8,130.4$ $129.8,128.7,128.5,128.3,128.2,127.9,127.8,127.2,126.9,126.75,126.69,126.61,126.56$, $126.4,126.0,125.9,125.24,125.17,125.02,124.95,124.85,124.4,124.29,124.28,122.9,122.8$ 121.1, 121.0; MS $m / z 630\left(\mathrm{M}^{+}\right), 503,350,315$. HRMS: calcd for $\mathrm{C}_{50} \mathrm{H}_{30}, 630.2348$; found, 630.2351.

Propargylic Diol 390. The following procedure is representative for the preparation of the propargylic alcohol. To a solution of $0.794 \mathrm{~g}$ (3.15 mmol) of 1-(2-ethynylphenyl)-2-(1naphthyl)ethyne $\mathbf{3 8 8}$ in $50 \mathrm{~mL}$ of diethyl ether under a nitrogen atmosphere at $0{ }^{\circ} \mathrm{C}$ was added $1.20 \mathrm{~mL}$ of a $2.5 \mathrm{M}$ solution of $n$-butyllithium $(3.00 \mathrm{mmol})$ in hexanes. The reaction mixture 
was then allowed to warm to room temperature. After $30 \mathrm{~min}$ at room temperature, a solution of $0.331 \mathrm{~g}$ (1.35 mmol) 389 in $40 \mathrm{~mL}$ of diethyl ether was introduced via cannula. After an additional $2 \mathrm{~h}, 30 \mathrm{~mL}$ of water was introduced, and the organic layer was separated. The aqueous layer was back extracted with diethyl ether. The combined organic extracts were washed with brine and water, dried over sodium sulfate, and concentrated. Flash column chromatography ( silica gel/20\% diethyl ether in hexanes) provided $1.00 \mathrm{~g}$ of $\mathbf{3 9 0}(1.33 \mathrm{mmol}, 99 \%, 1: 1 \mathrm{mixture}$ of diastereomers) as a white solid. Some fractions were found to contain only one of the two diastereomers. Diastereomer 1: $\operatorname{mp} 87-90^{\circ} \mathrm{C}$; IR 3566, 3447, 2214, 982, 841, 799, 773, 757 $\mathrm{cm}^{-1} ;{ }^{1} \mathrm{H} \delta 8.44(2 \mathrm{H}, \mathrm{dd}, J=6.2,3.5 \mathrm{~Hz}), 7.77-7.66(8 \mathrm{H}, \mathrm{m}), 7.61-7.56(2 \mathrm{H}, \mathrm{m}), 7.47-7.34$ (14 H, m), 2.13 (2 H, br), $0.98(18 \mathrm{H}, \mathrm{s}) ;{ }^{13} \mathrm{C} \delta 140.8,133.1,133.0,132.35,132.26,130.5,129.0$, $128.2,128.13,128.08,126.8,126.4,126.3,126.2,125.8,125.3,125.2,120.6,96.5,93.0,91.4$, 84.6, 79.3, 39.7, 25.5; MS m/z $773\left(\mathrm{MNa}^{+}\right)$, 733, 716, 693, 676. HRMS: calcd for $\mathrm{C}_{56} \mathrm{H}_{46} \mathrm{O}_{2} \mathrm{Na}$, 773.3390; found, 773.3419. Diastereomer 2: $\mathrm{mp} 191-193{ }^{\circ} \mathrm{C}$; IR 3566, 3447, 2214, 982, 841, 799, 773, $757 \mathrm{~cm}^{-1} ;{ }^{1} \mathrm{H} \delta 8.47-8.42$ (2 H, m), 7.83-7.77 (4 H, m), 7.72-7.65 (4 H, m), 7.54-7.42 (10 H, m), 7.40-7.28 (6 H, m), 2.33 (2 H, br), 0.96(18 H, s); ${ }^{13} \mathrm{C} \delta 140.8,133.2,133.1,132.3$, $132.2,130.5,128.9,128.2,128.1,128.0,126.8,126.34,126.27,125.8,125.2,120.6,96.4,93.0$, 91.3, 84.6, 79.3, 39.7, 25.5; MS $m / z 773\left(\mathrm{MNa}^{+}\right), 733,716,693,676$. HRMS: calcd for $\mathrm{C}_{56} \mathrm{H}_{46} \mathrm{O}_{2} \mathrm{Na}$, 773.3390; found, 773.3419.

Tetraacetylenic Hydrocarbon 391. The following procedure is representative for the preparation of the di/tetraacetylenic hydrocarbons. To a mixture of $0.893 \mathrm{~g}(1.19 \mathrm{mmol})$ of 390 and $0.829 \mathrm{~g}(7.15 \mathrm{mmol})$ of triethylsilane in $50 \mathrm{~mL}$ of methylene chloride under a nitrogen atmosphere at $0{ }^{\circ} \mathrm{C}$ was added $1.00 \mathrm{~mL}$ trifluoroacetic acid $(1.54 \mathrm{~g}, 13.5 \mathrm{mmol})$. After $15 \mathrm{~min}$ at $0{ }^{\circ} \mathrm{C}$, the reaction mixture was allowed to warm to room temperature. After an additional 10 
min, $0.77 \mathrm{~g}(7.26 \mathrm{mmol})$ sodium carbonate was added followed by $10 \mathrm{~mL}$ of water and $50 \mathrm{~mL}$ of diethyl ether. The organic layer was separated. The aqueous layer was back extracted with diethyl ether. The combined organic extracts were washed with brine and water, dried over sodium sulfate, and concentrated. Flash column chromatography (silica gel $/ 5 \%$ diethyl ether in hexanes) provided $0.817 \mathrm{~g}$ of 391 (1.14 mmol, 96\%, 1:1 mixture of diastereomers) as a light yellow solid: $\mathrm{mp} 155-158^{\circ} \mathrm{C}$; IR 2247, 2227, 907, 840, 800, 774, 758, $732 \mathrm{~cm}^{-1} ;{ }^{1} \mathrm{H} \delta 8.59-8.52$ (2 H, m), 7.90-7.68 (8 H, m), 7.62-7.28 (12 H, m), 7.21-7.18 (4 H, m), 3.67-3.64 (2 H, s), 0.99 $(18 \mathrm{H}, \mathrm{s}) ;{ }^{13} \mathrm{C} \delta 137.24,137.16,133.2,133.1,132.3,132.2,132.1,130.5,130.4,128.83,128.76$, $128.1,128.0,127.4,126.7,126.46,126.43,126.3,125.7,125.6,125.2,120.9,120.8,96.01$, 95.96, 93.44, 93.41, 91.0, 90.9, 82.6, 50.2, 35.5, 27.7; MS $m / z 718\left(\mathrm{M}^{+}\right), 661,605,397$. HRMS: calcd for $\mathrm{C}_{56} \mathrm{H}_{46}, 718.3600$; found, 718.3585 .

4,5-Di(1-naphthyl)phenanthrene 384. The following procedure is representative for the cyclization reactions. To $0.552 \mathrm{~g}(0.769 \mathrm{mmol})$ of $391 \mathrm{in} 50 \mathrm{~mL}$ of anhydrous toluene under a nitrogen atmosphere was added $1.7 \mathrm{~mL}$ of a $1.0 \mathrm{M}$ solution of potassium tert-butoxide (1.7 mmol) in 2-methyl-2-propanol. The reaction mixture was then heated under reflux for $4 \mathrm{~h}$. After the reaction mixture cooled to room temperature, $10 \mathrm{~mL}$ of water was introduced, and the organic layer was separated. The aqueous layer was back extracted with diethyl ether. The combined organic extracts were washed with water, dried over sodium sulfate, and concentrated. Crystallization of the residue from a mixture of hexanes and diethyl ether (4:1) afforded $0.163 \mathrm{~g}$ of $392(0.227 \mathrm{mmol}, 30 \%)$ as a yellow solid. The remaining part was purified by flash column chromatography to provide $0.285 \mathrm{~g}$ of $\mathbf{3 8 4}(0.397 \mathrm{mmol}, 52 \%$, a mixture of diastereomers of syn, anti 1 , and anti 2 , isomer ratio $=4.1: 1.7: 1)$ as a yellow solid. 392: $\mathrm{mp} 287-290^{\circ} \mathrm{C}$; IR 903, 796, $778,760,724 \mathrm{~cm}^{-1} ;{ }^{1} \mathrm{H} \delta 8.46-8.45(2 \mathrm{H}, \mathrm{s}), 8.14(2 \mathrm{H}, \mathrm{d}, J=8.2 \mathrm{~Hz}), 8.06(2 \mathrm{H}, \mathrm{d}, J=8.4 \mathrm{~Hz})$, 
7.77-7.70 (2 H, m), 7.59-7.39 (8 H, m), 7.24-7.17 (2 H, m), $7.11(2 \mathrm{H}, \mathrm{t}, J=7.4 \mathrm{~Hz}), 6.79(2 \mathrm{H}$, $\mathrm{t}, J=7.7 \mathrm{~Hz}), 6.22(2 \mathrm{H}, \mathrm{dd}, J=7.8,2.1 \mathrm{~Hz}), 4.47(4 \mathrm{H}, \mathrm{s}), 1.274-1.269(18 \mathrm{H}, \mathrm{s}) ;{ }^{13} \mathrm{C} \delta 144.2$, $140.2,140.0,138.43,138.42,138.00,137.95,136.63,136.56,134.0,133.0,132.1,130.6,128.1$, $127.94,127.86,127.44,127.42,126.9,126.5,126.3,126.2,126.1,123.9,123.7,39.8,38.2,33.5$ MS $m / z 718\left(\mathrm{M}^{+}\right), 662,646,605$. HRMS: calcd for $\mathrm{C}_{56} \mathrm{H}_{46}, 718.3600$; found, 718.3592. 384 (syn isomer): $\mathrm{mp} 255-258{ }^{\circ} \mathrm{C}$; IR 799, 776, 750, 738, $729 \mathrm{~cm}^{-1} ;{ }^{1} \mathrm{H} \delta 7.96(1 \mathrm{H}, \mathrm{d}, J=9.4 \mathrm{~Hz})$, $7.92(1 \mathrm{H}, \mathrm{d}, J=9.2 \mathrm{~Hz}), 7.76(1 \mathrm{H}, \mathrm{d}, J=7.4 \mathrm{~Hz}), 7.73(1 \mathrm{H}, \mathrm{d}, J=7.2 \mathrm{~Hz}), 7.57(1 \mathrm{H}, \mathrm{d}, J=7.9$ Hz), $7.33(1 \mathrm{H}, \mathrm{d}, J=7.4 \mathrm{~Hz}), 7.28-7.13(4 \mathrm{H}, \mathrm{m}), 7.09(1 \mathrm{H}, \mathrm{d}, J=7.9 \mathrm{~Hz}), 6.93(1 \mathrm{H}, \mathrm{t}, J=7.3$ Hz), 6.87-6.76 (3 H, m), 6.63-6.58 (2 H, m), 6.49-6.43 (2 H, m), 6.24 (1 H, t, $J=7.8 \mathrm{~Hz}), 5.97$ $(1 \mathrm{H}, \mathrm{t}, J=7.5 \mathrm{~Hz}), 5.89(1 \mathrm{H}, \mathrm{dd}, J=7.7,1.6 \mathrm{~Hz}), 5.01(1 \mathrm{H}, \mathrm{d}, J=7.7 \mathrm{~Hz}), 4.98(1 \mathrm{H}, \mathrm{d}, J=$ $7.9 \mathrm{~Hz}), 4.41(1 \mathrm{H}, \mathrm{d}, J=21.0 \mathrm{~Hz}), 4.23(1 \mathrm{H}, \mathrm{d}, J=20.5 \mathrm{~Hz}), 4.19(1 \mathrm{H}, \mathrm{d}, J=21.0 \mathrm{~Hz}), 4.02(1$ $\mathrm{H}, \mathrm{d}, J=20.8 \mathrm{~Hz}), 1.88(9 \mathrm{H}, \mathrm{s}), 1.83(9 \mathrm{H}, \mathrm{s}) ;{ }^{13} \mathrm{C} \delta 144.0,143.6,141.2,140.5,139.8,139.4$ 138.9, 138.6, 138.4, 135.3, 134.5, 133.71, 133.67, 133.2, 132.9, 132.5, 132.4, 131.8, 131.7, $131.3,130.0,128.3,127.9,127.6,127.5,127.2,126.1,125.9,125.80,125.75,125.6,125.4$, $125.03,124.97,124.6,124.51,124.48,123.5,122.98,122.93,122.3,121.7,39.9,39.6,38.0$, 37.7, 33.5, 33.1; MS m/z $718\left(\mathrm{M}^{+}\right), 661,605,519$. HRMS: calcd for $\mathrm{C}_{56} \mathrm{H}_{46}, 718.3600$; found, 718.3573. Recrystallization of the syn isomer of $\mathbf{3 8 4}$ from $\mathrm{CH}_{2} \mathrm{Cl}_{2} / 2$-propanol produced a crystal suitable for X-ray structure analysis (Figure 7). Anti isomer 1 (Partial signal): ${ }^{1} \mathrm{H} \delta 7.94(2 \mathrm{H}, \mathrm{d}$, $J=8.2 \mathrm{~Hz}), 5.50(2 \mathrm{H}, \mathrm{d}, J=7.9 \mathrm{~Hz}), 4.15(1 \mathrm{H}, \mathrm{d}, J=19.2 \mathrm{~Hz}), 4.05(1 \mathrm{H}, \mathrm{d}, J=21.0 \mathrm{~Hz}), 1.85$ $(18 \mathrm{H}, \mathrm{s}) ;{ }^{13} \mathrm{C} \delta 143.9,37.84,33.3$. Anti isomer 2 (Partial signal): ${ }^{1} \mathrm{H} \delta 6.18(2 \mathrm{H}, \mathrm{t}, J=7.7 \mathrm{~Hz})$, $4.58(2 \mathrm{H}, \mathrm{d}, J=8.2 \mathrm{~Hz}), 4.44(1 \mathrm{H}, \mathrm{d}, J=21.0 \mathrm{~Hz}), 1.92(9 \mathrm{H}, \mathrm{s}), 1.90(9 \mathrm{H}, \mathrm{s}) ;{ }^{13} \mathrm{C} \delta 143.6$, 37.76, 33.1. The formation of $\mathbf{3 9 3}$ was detected in the crude reaction products with ${ }^{1} \mathrm{H}$ NMR signals (partial) at $\delta 8.48(1 \mathrm{H}, \mathrm{s}), 8.46(1 \mathrm{H}, \mathrm{s}), 1.05(9 \mathrm{H}, \mathrm{s}), 1.02(9 \mathrm{H}, \mathrm{s})$. 
1-(2-Bromophenyl)-2-(1-naphthyl)ethyne 402. To a flask containing $0.45 \mathrm{~g}(0.64 \mathrm{mmol})$ of dichlorobis(triphenylphosphine)palladium and $0.21 \mathrm{~g}(1.1 \mathrm{mmol})$ of $\mathrm{CuI}$ were added via cannula a solution of $3.76 \mathrm{~g}$ (13.3 mmol) 1-bromo-2-iodobenzene in $50 \mathrm{~mL}$ of triethylamine followed by a solution of $2.00 \mathrm{~g}(13.2 \mathrm{mmol})$ of 1-ethynylnaphthalene in $30 \mathrm{~mL}$ of triethylamine. The resulting mixture was heated under reflux and stirred vigorously. After 3 days, the reaction mixture was allowed to cool to room temperature and concentrated. $50 \mathrm{~mL}$ of a saturated ammonium chloride solution and $50 \mathrm{~mL}$ of diethyl ether were added. After filtration, the filtrate was extracted with diethyl ether. The combined organic extracts were washed with water, dried over magnesium sulfate, and concentrated. Purification of the residue by flash column chromatography (silica gel/hexanes) afforded $3.66 \mathrm{~g}$ (11.9 mmol, 90\%) of $\mathbf{4 0 2}$ as a white solid: mp 58-60 ${ }^{\circ} \mathrm{C}$; IR 2213, 799, 772, $752 \mathrm{~cm}^{-1} ;{ }^{1} \mathrm{H} \delta 8.60(1 \mathrm{H}, \mathrm{dd}, J=8.5,1.1 \mathrm{~Hz}), 7.87(2 \mathrm{H}, \mathrm{d}, J$ $=8.2 \mathrm{~Hz}), 7.82(1 \mathrm{H}, \mathrm{dd}, J=7.2,1.0 \mathrm{~Hz}), 7.70-7.45(5 \mathrm{H}, \mathrm{m}), 7.35(1 \mathrm{H}, \mathrm{td}, J=8.9,1.3 \mathrm{~Hz})$, $7.22(1 \mathrm{H}, \mathrm{td}, J=7.8,1.7 \mathrm{~Hz}) ;{ }^{13} \mathrm{C} \delta 133.4,133.3,133.2,132.5,130.7,129.4,129.2,128.2$, $127.1,126.9,126.5,126.4,125.6,125.5,125.2,120.6,92.7,92.2 ; \mathrm{MS} m / z 308\left(\mathrm{M}^{+}\right), 226,220$, 153.

1-(1-Naphthyl)-2-[2-(trimethylsilylethynyl)phenyl]ethyne 404. To a solution of $2.40 \mathrm{~g}$ (7.82 mmol) of $\mathbf{4 0 2}$ in $100 \mathrm{~mL}$ of anhydrous diethyl ether at $-78^{\circ} \mathrm{C}$ was added dropwise $4.70 \mathrm{~mL}$ of a $2.5 \mathrm{M}$ solution of $n$-butyllithium $(11.75 \mathrm{mmol})$ in hexanes. After one hour of stirring at $-78^{\circ} \mathrm{C}$, a solution of $3.02 \mathrm{~g}(11.89 \mathrm{mmol})$ of iodine in $100 \mathrm{~mL}$ of anhydrous diethyl ether was added via cannula. The reaction mixture was allowed to warm to $15{ }^{\circ} \mathrm{C}$ before $30 \mathrm{~mL}$ of a $5 \%$ sodium thiosulfate $\left(\mathrm{Na}_{2} \mathrm{~S}_{2} \mathrm{O}_{3}\right)$ solution was introduced. The organic layer was separated. The aqueous layer was back extracted with diethyl ether. The combined organic extracts were washed with water, dried over magnesium sulfate, and concentrated. The crude $\mathbf{4 0 3}$ was used in the next step 
without further purification. To a flask containing $0.30 \mathrm{~g}(0.43 \mathrm{mmol})$ of $\mathrm{Pd}\left(\mathrm{PPh}_{3}\right)_{2} \mathrm{Cl}_{2}$ and 0.12 $\mathrm{g}(0.63 \mathrm{mmol})$ of $\mathrm{CuI}$ were added via cannula a solution of $2.74 \mathrm{~g}(7.74 \mathrm{mmol}) \mathbf{4 0 3} \mathrm{in} 70 \mathrm{~mL}$ of triethylamine followed by a solution of $2.22 \mathrm{~g}(22.6 \mathrm{mmol})$ of (trimethylsilyl)acetylene in $40 \mathrm{~mL}$ of triethylamine. The resulting mixture was stirred vigorously at room temperature for $20 \mathrm{~h}$ before $50 \mathrm{~mL}$ of a saturated ammonium chloride solution and $50 \mathrm{~mL}$ of diethyl ether were added. After filtration, the filtrate was extracted with diethyl ether. The combined organic extracts were washed with water, dried over magnesium sulfate, and concentrated. Purification of the residue by flash column chromatography (silica gel/hexanes) afforded $2.33 \mathrm{~g}(7.19 \mathrm{mmol}, 92 \%$ overall yield for two steps) of $\mathbf{4 0 4}$ as colorless crystals: $\mathrm{mp} 78-80^{\circ} \mathrm{C}$; IR 2214, 2158, 861, 842, 799, 774, $758 \mathrm{~cm}^{-1} ;{ }^{1} \mathrm{H} \delta 8.61(1 \mathrm{H}, \mathrm{dd}, J=8.2,0.7 \mathrm{~Hz}), 7.91-7.83(3 \mathrm{H}, \mathrm{m}), 7.69-7.47(5 \mathrm{H}, \mathrm{m})$, 7.39-7.28 (2 H, m), $0.29(9 \mathrm{H}, \mathrm{s}) ;{ }^{13} \mathrm{C} \delta 133.2,132.6,132.0,130.7,128.9,128.3,128.2,127.9$, $126.8,126.5,126.4,126.0,125.4,125.2,120.9,103.7,98.7,92.9,91.6,0.02 ; \mathrm{MS} m / z 324\left(\mathrm{M}^{+}\right)$, 309, 293, 279, 263.

1-(2-Ethynylphenyl)-2-(1-naphthyl)ethyne 388. To $1.48 \mathrm{~g}(4.57 \mathrm{mmol})$ of 404 in $50 \mathrm{~mL}$ of diethyl ether were added $30 \mathrm{~mL}$ of a $10 \%$ sodium hydroxide solution and $50 \mathrm{~mL}$ of methanol. After $30 \mathrm{~min}$ at room temperature, the organic solvent was removed in vacuo. Water $(50 \mathrm{~mL})$ and diethyl ether $(100 \mathrm{~mL})$ were then added. The organic layer was separated. The aqueous layer was back extracted with diethyl ether. The combined organic extracts were washed with 2 M hydrochloric acid and water, dried over magnesium sulfate, and concentrated. Purification of the residue by flash column chromatography (silica gel/hexanes) afforded $1.13 \mathrm{~g}(4.48 \mathrm{mmol}$, 98\%) of $\mathbf{3 8 8}$ as a light brown solids: mp $60-62{ }^{\circ} \mathrm{C}$; IR 3285, 2212, 2106, 799, 773, $757 \mathrm{~cm}^{-1} ;{ }^{1} \mathrm{H}$ $\delta 8.70(1 \mathrm{H}, \mathrm{d}, J=7.9 \mathrm{~Hz}), 7.90-7.83(3 \mathrm{H}, \mathrm{m}), 7.70-7.46(5 \mathrm{H}, \mathrm{m}), 7.43-7.30(2 \mathrm{H}, \mathrm{m}), 3.48(1$ 
$\mathrm{H}, \mathrm{s}) ;{ }^{13} \mathrm{C} \delta 133.3,133.1,132.7,131.9,130.6,129.0,128.6,128.2,128.0,126.7,126.6,126.5$, 126.4, 125.2, 124.5, 120.8, 92.6, 91.7, 82.7, 81.3; MS m/z $252\left(\mathrm{M}^{+}\right), 224,125$.

Fluorenylmethanol 406. The same procedure was repeated as described for 376 except that $0.146 \mathrm{~g}(0.397 \mathrm{mmol})$ of $\mathbf{4 0 5}$ in $10 \mathrm{~mL}$ of THF was treated with $0.40 \mathrm{~mL}$ of a 2.0 M solution of LDA $(0.80 \mathrm{mmol})$ in heptane/tetrahydrofuran/-ethylbenzene, followed by $0.021 \mathrm{~g}(0.70 \mathrm{mmol})$ of paraformaldehyde to afford $0.136 \mathrm{~g}$ of $\mathbf{4 0 6}(0.342 \mathrm{mmol}, 86 \%)$ as a white solid: $\mathrm{mp} 182-185^{\circ} \mathrm{C}$; IR 3427 (br), 763, 745, 731, $702 \mathrm{~cm}^{-1}$; ${ }^{1} \mathrm{H} \delta$ 7.70-7.50 (12 H, m), 7.45-7.35 (3 H, m), 7.25 (1 H, td, $J=7.4,1.0 \mathrm{~Hz}), 7.06(1 \mathrm{H}, \mathrm{t}, J=7.8 \mathrm{~Hz}), 6.47(1 \mathrm{H}, \mathrm{d}, J=7.9 \mathrm{~Hz}), 4.38(1 \mathrm{H}, \mathrm{dd}, J=5.4,3.7$ $\mathrm{Hz}), 3.89(1 \mathrm{H}, \mathrm{dd}, J=11.1,3.6 \mathrm{~Hz}), 3.35(1 \mathrm{H}, \mathrm{dd}, J=10.9,5.9 \mathrm{~Hz}), 1.20(1 \mathrm{H}, \mathrm{br} \mathrm{s}) ;{ }^{13} \mathrm{C} \delta$ 145.9, 141.3, 139.0, 138.9, 138.6, 137.0, 135.7, 133.4, 133.3, 131.8, 130.7, 130.10, 130.08, $129.4,129.23,129.21,129.1,128.4,127.8,127.6,127.42,127.36,126.4,125.9,125.51,125.47$, $124.4,123.9,63.5,49.7$.

Compound 407 and 408 . To a flask containing $0.033 \mathrm{~g}(0.083 \mathrm{mmol})$ of 406 was added $0.201 \mathrm{~g}$ (1.42 mmol) of phosphorus pentoxide, followed by $10 \mathrm{~mL}$ of $p$-xylene via cannula. The reaction mixture was heated under reflux for $3 \mathrm{~h}$. After the reaction mixture cooled to room temperature, $10 \mathrm{~mL}$ of saturated sodium bicarbonate solution was introduced and the organic layer was separated. The aqueous layer was back extracted with diethyl ether. The combined organic extracts were washed with water $(3 \times 30 \mathrm{~mL})$, dried over magnesium sulfate, and concentrated. Flash column chromatography (silica gel $/ 5 \%$ methylene chloride in hexanes) provided $0.017 \mathrm{~g}$ of $407(0.045 \mathrm{mmol}, 54 \%)$ as a yellow solid and $0.010 \mathrm{~g}$ of $408(0.033 \mathrm{mmol}, 40 \%)$ as a yellow solid. Compound 407: $\mathrm{mp} 216-218^{\circ} \mathrm{C}$; IR 773, 750, $703 \mathrm{~cm}^{-1} ;{ }^{1} \mathrm{H} \delta 8.77(1 \mathrm{H}, \mathrm{d}, J=8.2 \mathrm{~Hz})$, $8.43(1 \mathrm{H}, \mathrm{d}, J=7.7 \mathrm{~Hz}), 7.76-7.35(11 \mathrm{H}, \mathrm{m}), 7.16(1 \mathrm{H}, \mathrm{td}, J=7.2,1.9 \mathrm{~Hz}), 6.99-6.85(3 \mathrm{H}$, m), $4.03(1 \mathrm{H}, \mathrm{dd}, J=14.8,5.4 \mathrm{~Hz}), 3.47(1 \mathrm{H}, \mathrm{dd}, J=13.9,5.4 \mathrm{~Hz}), 2.65(1 \mathrm{H}, \mathrm{t}, J=14.3 \mathrm{~Hz})$; 
${ }^{13} \mathrm{C} \delta 147.3,145.6,143.3,140.1,139.4,134.6,134.5,133.0,131.8,130.0,129.4,129.05,129.00$, $128.8,128.7,128.33,128.27,127.5,127.4,127.3,126.2,125.9,125.0,124.2,123.5,123.1,45.4$, 33.5; Compound 408: ${ }^{1} \mathrm{H} \delta 8.93(1 \mathrm{H}, \mathrm{d}, J=8.2 \mathrm{~Hz}), 8.50(1 \mathrm{H}, \mathrm{d}, J=7.9 \mathrm{~Hz}), 8.29(1 \mathrm{H}, \mathrm{s}), 8.14$ $(1 \mathrm{H}, \mathrm{d}, J=7.4 \mathrm{~Hz}), 8.00(1 \mathrm{H}, \mathrm{d}, J=7.9 \mathrm{~Hz}), 7.78-7.38(10 \mathrm{H}, \mathrm{m})$. The sample is too dilute to run ${ }^{13} \mathrm{C}$ NMR.

Repeated Experimental Procedures to synthesize hydrocarbon $\mathbf{3 6 9}$

Propargylic Alcohol. The same procedure was repeated as described for synthesis of propargylic alcohol except that $0.668 \mathrm{~g}(3.31 \mathrm{mmol})$ of 1-(2-ethynylphenyl)-2-phenylethyne was treated with $1.30 \mathrm{~mL}$ of a $2.5 \mathrm{M}$ solution of $n$-butyllithium $(3.25 \mathrm{mmol})$ in hexanes and $0.649 \mathrm{~g}$ (3.06 mmol) $t$-butyl 2-naphthyl ketone to afford $1.25 \mathrm{~g}$ of propargylic alcohol (3.02 $\mathrm{mmol}, 99 \%)$ as a light brown liquid: IR 3556, 3447, 2215, 823, 797, 756, $690 \mathrm{~cm}^{-1} ;{ }^{1} \mathrm{H} \delta 8.25(1 \mathrm{H}, \mathrm{d}, J=1.2$ Hz), $7.96(1 \mathrm{H}, \mathrm{dd}, J=8.7,1.7 \mathrm{~Hz}), 7.86-7.79(2 \mathrm{H}, \mathrm{m}), 7.71(1 \mathrm{H}, \mathrm{d}, J=8.9 \mathrm{~Hz}), 7.65-7.55(2$ H, m), 7.54-7.40 (4 H, m), 7.38-7.27 (3 H, m), 7.22-7.17 (2 H, m), $2.65(1 \mathrm{H}, \mathrm{br}), 1.20(9 \mathrm{H}, \mathrm{s})$; ${ }^{13} \mathrm{C} \delta 139.7,132.6,132.4,132.21,132.15,131.6,128.38,128.34,128.2,127.9,127.3,126.5$, $126.4,126.2,125.9,125.8,125.0,122.9,96.2,93.3,88.2,84.7,79.6,40.0,25.6$.

Diacetylenic Hydrocarbon. The same procedure was repeated as described for synthesis of di/tetraacetylenic hydrocarbons except that a mixture of $1.03 \mathrm{~g}(2.49 \mathrm{mmol})$ of propargylic alcohol and $0.866 \mathrm{~g}(7.47 \mathrm{mmol})$ of triethylsilane in $40 \mathrm{~mL}$ of methylene chloride was treated with $1.00 \mathrm{~mL}$ trifluoroacetic acid $(1.54 \mathrm{~g}, 13.5 \mathrm{mmol})$, followed by $1.06 \mathrm{~g}(10.0 \mathrm{mmol})$ sodium carbonate to afford $0.971 \mathrm{~g}$ of diacetylenic hydrocarbon $(2.44 \mathrm{mmol}, 98 \%)$ as white crystals: $\mathrm{mp}$ 103-105 ${ }^{\circ} \mathrm{C}$; IR 2214, 820, 756, $691 \mathrm{~cm}^{-1} ;{ }^{1} \mathrm{H} \delta 7.86(1 \mathrm{H}, \mathrm{s}), 7.81-7.61(4 \mathrm{H}, \mathrm{m}), 7.58-7.40(4$ $\mathrm{H}, \mathrm{m}), 7.36-7.23(5 \mathrm{H}, \mathrm{m}), 7.17-7.11(2 \mathrm{H}, \mathrm{m}), 3.90(1 \mathrm{H}, \mathrm{s}), 1.12(9 \mathrm{H}, \mathrm{s}) ;{ }^{13} \mathrm{C} \delta 136.9,133.0$ 
$132.4,132.13,132.07,131.6,128.4,128.19,128.17,128.1,127.88,127.85,127.5,127.4,127.0$, $126.3,125.8,125.6,125.5,123.2,95.6,92.8,88.5,82.6,50.8,35.8,27.9$.

Hydrocarbon 369. The same procedure was repeated as described for the cyclization reactions except that a mixture of $0.629 \mathrm{~g}(1.58 \mathrm{mmol})$ of diacetylenic hydrocarbon in $50 \mathrm{~mL}$ of anhydrous toluene was treated with $1.74 \mathrm{~mL}$ of a $1.0 \mathrm{M}$ solution of potassium tert-butoxide $(1.74 \mathrm{mmol})$ in 2-methyl-2-propanol to provide $0.504 \mathrm{~g}$ of $\mathbf{3 6 9}(1.27 \mathrm{mmol}, 80 \%)$ as a light yellow solid: $\mathrm{mp}$ 191-193 ${ }^{\circ} \mathrm{C}$; IR 908, 825, 753, 734, $702 \mathrm{~cm}^{-1} ;{ }^{1} \mathrm{H} \delta 8.42(1 \mathrm{H}, \mathrm{d}, J=9.4 \mathrm{~Hz}), 7.79(1 \mathrm{H}, \mathrm{d}, J=$ $7.7 \mathrm{~Hz}), 7.70-7.59(5 \mathrm{H}, \mathrm{s}), 7.52-7.35(4 \mathrm{H}, \mathrm{m}), 7.19(1 \mathrm{H}, \mathrm{t}, J=7.3 \mathrm{~Hz}), 7.03-6.91(2 \mathrm{H}, \mathrm{m})$, $6.00(1 \mathrm{H}, \mathrm{d}, J=7.9 \mathrm{~Hz}), 4.46(2 \mathrm{H}, \mathrm{s}), 1.90(9 \mathrm{H}, \mathrm{s}) ;{ }^{13} \mathrm{C} \delta 144.1,143.2,141.7,141.0,139.9$, 138.8, 134.0, 132.5, 131.4, 131.3, 130.4, 130.1, 129.9, 129.1, 127.7, 127.1, 126.5, 126.1, 126.0, $125.4,123.9,123.8,123.5,40.3,38.5,34.0$. 


\section{References}

1. Lee, M. D.; Ellestad, G. A.; Borders, D. B. Acc. Chem. Res. 1991, 24, 235-243.

2. (a) Konishi, M.; Ohkuma, H.; Matsumoto, K.; Tsuno, T.; Kamei, H.; Miyaki, T.; Oki, T.; Kawaguchi, H.; VanDuyne, G. D.; Clardy, J. J. Antibiot. 1989, 42, 1449-1452. (b) Konishi, M.; Ohkuma, H.; Tsuno, T.; Oki, T.; VanDuyne, G. D.; Clardy, J. J. Am. Chem. Soc. 1990, 112, $3715-3716$.

3. Golik, J.; Dubay, G.; Groenewold, G.; Kawaguchi, H.; Konishi, M.; Krishnan, B.; Ohkuma, H.; Saitoh, K.; Doyle, T. W. J. Am. Chem. Soc. 1987, 109, 3462-3464.

4. (a) Lam, K. S.; Hesler, G. A.; Gustavson, D. R.; Crosswell, A. R.; Veitch, J. M.; Forenza, S.; Tomita, K. J. Antibiot. 1991, 44, 472-478. (b) Leet, J. E.; Schroeder, D. R.; Hofstead, S. J.; Golik, J.; Colson, K. L.; Huang, S.; Klohr, S. E.; Doyle, T. W.; Matson, J. A. J. Am. Chem. Soc. 1992, 114, 7946-7948.

5. (a) Hu, J.; Xue, Y.-C.; Xie, M.-Y.; Zhang, R.; Otani, T.; Minami, Y.; Yamada, Y.; Marunaka, T. J. Antibiot. 1988, 41, 1575-1579. (b) Yoshida, K.; Minami, Y.; Azuma, R.; Saeki, M.; Otani, T. Tetrahedron Lett. 1993, 34, 2637-2640.

6. (a) Goldberg, I. H. Acc. Chem. Res. 1991, 24, 191-198. (b) Myers, A. G.; Proteau, P. J. J. Am. Chem. Soc. 1989, 111, 1146-1147.

7. McDonald, L. A.; Capson, T. L.; Krishnamurthy, G.; Ding, W.-D.; Ellestad, G. A.; Bernan, V. S.; Maiese, W. M.; Lassota, P.; Discafani, C.; Kramer, R. A.; Ireland, C. M. J. Am. Chem. Soc. 1996, 118, 10898-10899.

8. Oku, N.; Matsunaga, S.; Fusetani, N. J. Am. Chem. Soc. 2003, 125, 2044-2045.

9. For reviews, see: (a) Nicolaou, K. C.; Dai, W.-M. Angew. Chem., Int. Ed. Engl. 1991, 30, 1387-1416. (b) Grissom, J. W.; Gunawardena, G. U.; Klingberg, D.; Huang. D. Tetrahedron 
1996, 52, 6453-6518. (c) Maier, M. E. Synlett 1995, 13-26. (d) Saito, I.; Nakatani, K. Bull. Chem. Soc. Jpn. 1996, 69, 3007-3019.

10. Schmittel, M.; Keller, M.; Kiau, S.; Strittmatter, M. Chem. Eur. J. 1997, 3, 807-816.

11. For a review see: Wang, K. K. Chem. Rev. 1996, 96, 207-222.

12. Schmittel, M.; Strittmatter, M.; Kiau, S. Tetrahedron Lett. 1995, 36, 4975-4978.

13. Myers, A. G. Tetrahedron Lett. 1987, 28, 4493-4496.

14. Mayer, J.; Sondheimer, F. J. Am. Chem. Soc. 1966, 88, 603-604.

15. Darby, N.; Kim, C. U.; Salaün, J. A.; Shelton, K. W.; Takada, S.; Masamune, S. J. Chem. Soc., Chem. Commun. 1971, 1516-1517.

16. (a) Jones, R. R.; Bergman, R. G. J. Am. Chem. Soc. 1972, 94, 660-661. (b) Bergman, R. G. Acc. Chem. Res. 1973, 6, 25-31.

17. Lockhart, T. P.; Bergman, R. G. J. Am. Chem. Soc. 1981, 103, 4091-4096.

18. Nicolaou, K. C.; Smith, A. L.; Yue, E. W. Proc. Natl. Acad. Sci. USA 1993, 90, 5581.

19. (a) Nicolaou, K. C.; Zuccarello, G.; Ogawa, Y.; Schweiger, E. J.; Kumazawa, T. J. Am. Chem. Soc. 1988, 110, 4866-4868. (b) Nicolaou, K. C.; Ogawa, Y.; Zuccarello, G.; Kataoka, H. J. Am. Chem. Soc. 1988, 110, 7247-7248. (c) Wong, H. N. C.; Sondheimer, F. Tetrahedron Lett. 1980, 21, 217-220. (d) Guillerm, D.; Linstrumelle, G. Tetrahedron Lett. 1985, 26, 3811-3812. (e) Lockhart, T. P.; Comita, P. B.; Bergman, R. G. J. Am. Chem. Soc. 1981, 103, 4082-4090.

20. Magnus, P.; Carter, P.; Elliott, J.; Lewis, R.; Harling, J.; Pitterna, T.; Bauta, W. E.; Fortt, S. J. Am. Chem. Soc. 1992, 114, 2544-2559.

21. (a) Semmelhack, M. F.; Neu, T.; Foubelo, F. Tetrahedron Lett. 1992, 33, 3277-3280. (b) Semmelhack, M. F.; Neu, T.; Foubelo, F. J. Org. Chem. 1994, 59, 5038-5047.

22. Alabugin, I. V.; Manoharan, M.; Kovalenko, S. V Org. Lett. 2002, 4, 1119-1122. 
23. (a) Turro, N. J.; Evenzahav, A.; Nicolaou, K. C. Tetrahedron Lett. 1994, 35, 8089-8092. (b)

Funk, R. L.; Young, E. R. R.; Williams, R. M.; Flanagan, M. F.; Cecil, T. C. Abstracts of Papers; 34th National Organic Symposium, Williamsberg, VA; American Chemical Society; Washington, D. C., 1995, Abstract 261. (c) Kraft, B. J.; Coalter, N. L.; Nath, M.; Clark, A. E.; Siedle, A. R.; Huffman, J. C.; Zaleski, J. M. Inorg. Chem. 2003, 42, 1663-1672.

24. Warner, B. P.; Millar, S. P.; Broene, R. D.; Buchwald, S. L. Science 1995, 269, 814-816.

25. Coalter, N. L.; Concolino, T. E.; Streib, W. E.; Hughes, C. G.; Rheingold, A. L.; Zaleski, J. M. J. Am. Chem. Soc. 2000, 122, 3112-3117.

26. (a) Basak, A.; Shain, J. C.; Khamrai, U. K.; Rudra, K. R.; Basak, A. J. Chem. Soc., Perkin Trans. 1 2000, 1955-1964. (b) Benites, P.; Rawat, D. S.; Zaleski, J. M. J. Am. Chem. Soc. 2000, 122, 7208-7217. (c) Rawat, D. S.; Zaleski, J. M. J. Am. Chem. Soc. 2001, 123, 9675-9676.

27. (a) Myers, A. G.; Kuo, E. Y.; Finney, N. S. J. Am. Chem. Soc. 1989, 111, 8057-8059. (b) Myers, A. G.; Dragovich, P. S. J. Am. Chem. Soc. 1989, 111, 9130-9132. (c) Koga, N.; Morokuma, K. J. Am. Chem. Soc. 1991, 113, 1907-1911.

28. (a) Nagata, R.; Yamanaka, H.; Okazaki, E.; Saito, I. Tetrahedron Lett. 1989, 30, 4995-4998. (b) Nagata, R.; Yamanaka, H.; Murahashi, E.; Saito, I. Tetrahedron Lett. 1990, 31, 2907-2910.

29. (a) Schmittel, M.; Strittmatter, M.; Kiau, S. Angew. Chem., Int. Ed. Engl. 1996, 35, 1843-1845. (b) Schmittel, M.; Kiau, S. Liebigs Ann./Recueil 1997, 733- 736. (c) Schmittel, M.; Strittmatter, M.; Vollmann, K.; Kiau, S. Tetrahedron Lett. 1996, 37, 999-1002. (d) Schmittel, M.; Steffen, J.-P.; Auer, D.; Maywald, M. Tetrahedron Lett. 1997, 38, 6177-6180. (e) Schmittel, M.; Strittmatter, M. Tetrahedron 1998, 54, 13751-13760. (f) Schmittel, M.; Kiau, S.; Siebert, T.; Strittmatter, M. Tetrahedron Lett. 1996, 37, 7691-7694. (g) Schmittel, M.; Maywald, M.; Strittmatter, M. Synlett 1997, 165-166. 
30. (a) Musch, P. W.; Engels, B. J. Am. Chem. Soc. 2001, 123, 5557-5562. (b) Engels, B.; Hanrath, M. J. Am. Chem. Soc. 1998, 120, 6356-6361. (c) Engels, B.; Lennartz, C.; Hanrath, M.; Schmittel, M.; Strittmatter, M. Angew. Chem., Int. Ed. 1998, 37, 1960-1963. (d) Wenthold, P. G.; Lipton, M. A. J. Am. Chem. Soc. 2000, 122, 9265-9270. (e) Schreiner, P. R.; Prall, M. J. Am. Chem. Soc. 1999, 121, 8615-8627. (f) Stahl, F.; Moran, D.; Schleyer, P. v. R.; Prall, M.; Schreiner, P. R. J. Org. Chem. 2002, 67, 1453-1461.

31. Schmittel, M.; Maywald, M. Chem. Commun. 2001, 155-156.

32. (a) Zhang, H.-R.; Wang, K. K. J. Org. Chem. 1999, 64, 7996-7999. (b) Li, H.; Zhang, H.R.; Petersen, J. L.; Wang, K. K. J. Org. Chem. 2001, 66, 6662-6668.

33. Li, H.; Petersen, J. L.; Wang, K. K. J. Org. Chem. 2001, 66, 7804-7810.

34. Our group's unpublished results.

35. (a) Gillmann, T.; Hülsen, T.; Massa, W.; Wocadlo, S. Synlett 1995, 1257-1259. (b) Garcia, J. G.; Ramos, B.; Pratt, L. M.; Rodríguez, A. Tetrahedron Lett. 1995, 36, 7391-7394.

36. Brunette, S. R.; Lipton, M. A. J. Org. Chem. 2000, 65, 5114-5119.

37. (a) Naoe, Y.; Kikuishi, J.; Ishigaki, K.; Iitsuka, H.; Nemoto, H.; Shibuya, M. Tetrahedron Lett. 1995, 36, 9165-9168. (b) Suzuki, I.; Shigenaga, A.; Nemoto, H.; Shibuya, M. Heterocycles 2001, 54, 571-576.

38. Schmittel, M.; Steffen, J.-P.; Ángel, M. Á. W.; Engels, B.; Lennartz, C.; Hanrath, M. Angew. Chem. Int. Ed. 1998, 37, 1562-1564.

39. (a) Sullivan, R. W.; Coghlan, V. M.; Munk, S. A.; Reed, M. W.; Moore, H. W. J. Org. Chem. 1994, 59, 2276-2278. (b) Foland, L. D.; Karlsson, J. O.; Perri, S. T.; Schwabe, R.; Xu, S. L.; Patil, S.; Moore, H. W. J. Am. Chem. Soc. 1989, 111, 975-989. (c) Reed, M. W.; Pollart, D. J.; Perri, S. T.; Foland, L. D.; Moore, H. W. J. Org. Chem. 1988, 53, 2477-2482. (d) Liebeskind, 
L. S.; Fengl, R. W.; Wirtz, K. R.; Shawe, T. T. J. Org. Chem. 1988, 53, 2482-2488. (e) Liebeskind, L. S.; Foster, B. S. J. Am. Chem. Soc. 1990, 112, 8612-8613. (f) Perri, S. T.; Foland, L. D.; Moore, H. W. Tetrahedron Lett. 1988, 29, 3529-3532. (g) Xia, H.; Moore, H. W. J. Org. Chem. 1992, 57, 3765-3766. (h) Tarli, A.; Wang, K. K. J. Org. Chem. 1997, 62, 8841-8847.

40. (a) Schmittel, M.; Steffen, J.-P.; Engels, B.; Lennartz, C.; Hanrath, M. Angew. Chem. Int. Ed. 1998, 37, 2371-2373. (b) Schmittel, M.; Steffen, J.-P.; Maywald, M.; Engels, B.; Helten, H.; Musch, P. J. Chem. Soc., Perkin Trans. 2 2001, 1331-1339. (c) Schmittel, M.; Rodríguez, D.; Steffen, J.-P. Angew. Chem. Int. Ed. 2000, 39, 2152-2155.

41. (a) Shi, C.; Wang, K. K. J. Org. Chem. 1998, 63, 3517-3520. (b) Shi, C.; Zhang, Q.; Wang, K. K. J. Org. Chem. 1999, 64, 925-932. (c) Zhang, Q.; Shi, C.; Zhang, H.-R.; Wang, K. K. J. Org. Chem. 2000, 65, 7977-7983. (d) Lu, X.; Petersen, J. L.; Wang, K. K. J. Org. Chem. 2002, 67, 5412-5415. (e) Lu, X.; Petersen, J. L.; Wang, K. K. J. Org. Chem. 2002, 67, 7797-7801. (f) Li, H.; Petersen, J. L.; Wang, K. K. J. Org. Chem. 2003, 68, 5512-5518.

42. Sevin, A.; Chodkiewicz, W. Tetrahedron Lett. 1967, 2975-2980.

43. Nicolaou, K. C.; Maligres, P.; Shin, J.; de Leon, E.; Rideout, D. J. Am. Chem. Soc. 1990, $112,7825-7826$.

44. (a) Grissom, J. W.; Klingberg, D.; Huang, D.; Slattery, B. J. J. Org. Chem. 1997, 62, 603-606. (b) Grissom, J. W.; Huang, D. J. Org. Chem. 1994, 59, 5114-5116.

45. (a) Lutz, R. Chem. Rev. 1984, 84, 205-247. (b) Viola, A.; Collins, J. J.; Filipp, N. Tetrahedron 1981, 37, 3765-3811. (c) Bennett, G. B. Synthesis 1977, 589-606. (d) Harusawa, S.; Moriyama, H.; Kase, N.; Ohishi, H.; Yoneda, R.; Rurihara, T. Tetrahedron 1995, 51, $6475-6494$. 
46. (a) Nicolaou, K. C.; Skokotas, G.; Maligres, P.; Zuccarello, G.; Schweiger, E. J.; Toshima, K.; Wendeborn, S. Angew. Chem. Int. Ed. Engl. 1989, 28, 1272-1275. (b) Wu, M.-J.; Lin, C.-F.; Wu, J.-S.; Chen, H.-T. Tetrahedron Lett. 1994, 35, 1879-1882. (c) Grissom, J. W.; Klingberg, D. Tetrahedron Lett. 1995, 36, 6607-6610. (d) Wu, M.-J.; Lin, C.-F.; Jing, P.-T.; Chang, L.-J.; Duh, T.-H.; Lee, F.-C.; Chen, H.-T. J. Chinese Chem. Soc. 1998, 45, 475-479.

47. Dopico, P. G.; Finn, M. G. Tetrahedron 1999, 55, 29-62.

48. Gillmann, T.; Heckhoff, S.; Weeber, T. Syn. Commun. 1994, 24, 2133-2138.

49. Cunico, R. F.; Nair, S. K. Tetrahedron Lett. 1997, 38, 25-28.

50. (a) Wang, K. K.; Wang, Z. Tetrahedron Lett. 1994, 35, 1829-1832. (b) Wang, K. K.; Wang, Z. J. Org. Chem. 1996, 61, 1516-1518. (c) Wang, Z.; Wang, K. K. J. Org. Chem. 1994, 59, 4738-4742. (d) Liu, B.; Wang, K. K.; Petersen, J. L. J. Org. Chem. 1996, 61, 8503-8507. (e) Wang, K. K.; Zhang, H.-R. Petersen, J. L. J. Org. Chem. 1999, 64, 1650-1656. (f) Wang, K. K.; Liu, B.; Lu, Y.-D. Tetrahedron Lett. 1995, 36, 3785-3788. (g) Andemichael, Y. W.; Gu, Y. G.; Wang, K. K. J. Org. Chem. 1992, 57, 794-796.

51. Tabuchi, T.; Inanaga, J.; Yamaguchi, M. Tetrahedron Lett. 1986, 27, 5237-5240.

52. (a) Bailey, N. A.; Hull, S. E. Acta Crystallogr., Sect. B 1978, 34, 3289-3295. (b) Molins, E.; Miravitlles, C.; Espinosa, E.; Ballester, M. J. Org. Chem. 2002, 67, 7175-7178. (c) Ballester, M.; Castañer, J.; Riera, J.; de la Fuente, G.; Camps, M. J. Org. Chem. 1985, 50, 2287-2292. (d) Lemmen, P.; Lenoir, D. Chem. Ber. 1984, 117, 2300-2313. (e) Lenoir, D.; Lemmen, P. Chem. Ber. 1980, 113, 3112-3119. (f) Gosnay, I.; Bergmann, E. D.; Rabinovitz, M.; Agranat, I. Isr. J. Chem. 1972, 10, 423-437.

53. White, D. M. J. Org. Chem. 1974, 39, 1951-1952. 
54. (a) Gault, I. R.; Ollis, W. D.; Sutherland, I. O. Chem. Commun. 1970, 269-271. (b) Agranat, I.; Rabinovitz, M.;Weitzen-Dagan, A.; Gosnay, I. J. Chem. Soc., Chem. Commun. 1972, $732-733$.

55. Mallakpour, S. E. Indian J. Chem. 1997, 36B, 354-356.

56. Zhang, H.-R. Ph.D. Dissertation, Department of Chemistry, West Virginia University, 2000.

57. Han, X. MS Thesis, Department of Chemistry, West Virginia University, 2001.

58. Baldwin, J. E.; Bennett, P. A. R.; Forrest, A. K. J. Chem. Soc., Chem. Commun. 1987, $250-251$.

59. (a) Scott, L. T.; Hashemi, M. M.; Meyer, D. T.; Warren, H. B.; J. Am. Chem. Soc. 1991, 113, 7082-7084. (b) Scott, L. T. Pure Appl. Chem. 1996, 68, 291-300. (c) Scott, L.T.; Hashemi, M. M.; Bratcher, M. S. J. Am. Chem. Soc. 1992, 114, 1920-1921.

60. (a) Scott, L. T.; Cheng, P.-C.; Hashemi, M. M.; Bratcher, M. S.; Meyer, D. T.; Warren, H. B. J. Am. Chem. Soc. 1997, 119, 10963-10968. (b) Ansems, R. B. M.; Scott, L. T. J. Am. Chem. Soc. 2000, 122, 2719-2724. (c) Bronstein, H. E.; Choi, N.; Scott, L. T. J. Am. Chem. Soc. 2002, 124, 8870-8875. (d) Scott, L. T.; Bronstein, H. E.; Preda, D. V.; Ansems, R. B. M.; Bratcher, M. S.; Hagen, S. Pure Appl. Chem. 1999, 71, 209-219. (e) Mehta, G.; Rao, H. S. P. Tetrahedron 1998, 54, 13325-13370. (f) Rabideau, P. W.; Sygula, A. Acc. Chem. Res. 1996, 29, 235-242. (g) Knölker, H.-J.; Braier, A.; Bröcher, D. J.; Jones, P.G.; Piotrowski, H. Tetrahedron Lett. 1999, 40, 8075-8078. (h) Mehta, G.; Panda, G. Tetrahedron Lett. 1997, 38, 2145-2148. (i) Abdourazak, A. H.; Sygula, A.; Rabideau, P. W. J. Am. Chem. Soc. 1993, 115, 3010-3011. (j) Liu, C. Z.; Rabideau, P. W. Tetrahedron Lett. 1996, 37, 3437-3440. (k) Zimmermann, G.; Nuechter, U.; Hagen, S.; Nuechter, M Tetrahedron Lett. 1994, 35, 4747-4750. (1) Borchardt, A.; Fuchicello, A.; Kilway, K. V.; Baldridge, K. K.; Siegel, J. S. J. Am. Chem. Soc. 1992, 114, 1921-1923. 
61. (a) Barth, W. E.; Lawton, R. G. J. Am. Chem. Soc. 1971, 93, 1730-1745. (b) Barth, W. E.; Lawton, R. G. J. Am. Chem. Soc. 1966, 88, 380-381.

62. Crombie, D. A.; Shaw, S. J. Chem. Soc. C. 1969, 2489-2490.

63. Chang, H.-F.; Cho, B. P. J. Org. Chem. 1999, 64, 9051-9056.

64. Studt, P.; Win, T. Liebigs Ann. Chem. 1983, 519.

65. (a) Dosa, P. I.; Schleifenbaum, A.; Vollhardt, K. P. C. Org. Lett. 2001, 3, 1017-1020. (b) Brooks, M. A.; Scott, L. T. J. Am. Chem. Soc. 1999, 121, 5444-5449. (c) Sarobe, M.; Jenneskens, L. W.; Wiersum, U. E. Tetrahedron Lett. 1997, 38, 4689-4692. (d) Plater, M. J. Tetrahedron Lett. 1994, 35, 6147-6150.

66. (a) Craig, J. T.; Robins, M. D. W. Aust. J. Chem. 1968, 21, 2237- 2245. (b) Davy, J. R.; Iskander, M. N.; Reiss, J. A. Aust. J. Chem. 1979, 32, 1067-1078.

67. Mehta, G.; Sarma, P. V. V. S. Chem. Commun. 2000, 19-20.

68. (a) Marcinow, Z.; Sygula, A.; Ellern, A.; Rabideau, P. W. Org. Lett. 2001, 3, 3527-3529. (b) Sygula, A.; Karlen, S. D.; Sygula, R.; Rabideau, P. W. Org. Lett. 2002, 4, 3135-3137.

69. Seiders, T. J.; Baldridge, K. K.; Siegel, J. S. J. Am. Chem. Soc. 1996, 118, 2754-2755.

70. (a) Sygula, A.; Rabideau, P. W. J. Am. Chem. Soc. 1998, 120, 12666-12667. (b) Sygula, A.; Rabideau, P. W. J. Am. Chem. Soc. 1999, 121, 7800-7803. (c) Seiders, T. J.; Elliott, E. L.; Grube, G. H.; Siegel, J. S. J. Am. Chem. Soc. 1999, 121, 7804-7813.

71. (a) Sygula, A.; Rabideau, P. W. J. Am. Chem. Soc. 2000, 122, 6323-6324. (b) Sygula, A.; Xu, G.; Marcinow, Z.; Rabideau, P. W. Tetrahedron 2001, 57, 3637-3644. (c) Marcinow, Z.; Grove, D. I.; Rabideau, P. W. J. Org. Chem. 2002, 67, 3537-3539.

72. Reisch, H. A.; Bratcher, M. S.; Scott, L. T. Org. Lett. 2000, 2, 1427-1430.

73. Sygula, A.; Sygula, R.; Ellern, A.; Rabideau, P. W. Org. Lett. 2003, 5, 2595-2597. 
74. Taylor, E. C.; Chiang, C.-S.; McKillop, A.; White, J. F. J. Am. Chem. Soc. 1976, 98, $6750-6752$.

75. (a) Nongrum, F. M.; Myrboh, B. Synthesis 1987, 845-846. (b) Myrboh, B.; Ila, H.; Junjappa, H. Synthesis, 1981, 126-127.

76. (a) Mathew, F.; Myrboh, B. Syn. Commun. 1996, 26, 1097-1101. (b) Fujii, K.; Nakao, K.; Yamauchi, T. Synthesis 1982, 456-457. (c) Varma, R. S.; Kumar, D. Synthesis 1999, $1288-1290$.

77. (a) Wiberg, K. B.; Furtek, B. L.; Olli, L. K. J. Am. Chem. Soc. 1979, 101, 7675-7679. (b) Trost, B. M.; Kinson, P. L. J. Am. Chem. Soc. 1975, 97, 2438-2449. (c) Sasaki, T.; Eguchi, S.; Hirako, Y. J. Org. Chem. 1977, 42, 2981-2985. (d) Meinwald, J.; Gassman, P. G. J. Am. Chem. Soc. 1960, 82, 2857-2863. (e) Wiberg, K. B.; Olli, L. K.; Golembeski, N.; Adams, R. D. J. Am. Chem. Soc. 1980, 102, 7467-7475. (f) Fessner, W.-D.; Sedelmeier, G.; Spur, P. R.; Rihs, G.;

Prinzbach, H. J. Am. Chem. Soc. 1987, 109, 4626-4642. (g) Wiberg, K. B.; Hess, B. A., Jr. J. Org. Chem. 1966, 31, 2250-2254.

78. (a) Curphey, T. J. Org. Prep. Proced. Int. 1981, 13, 112-115. (b) Taber, D. F.; Ruckle, R. E., Jr.; Hennessy, M. J. J. Org. Chem. 1986, 51, 4077-4078.

79. (a) Cava, M. P.; Litle, R. L.; Napier, D. R. J. Am. Chem. Soc. 1958, 80, 2257-2263. (b) Horner, L.; Muth, K.; Schmelzer, H.-G. Chem. Ber. 1959, 92, 2953-2957.

80. (a) Ireland, R. E.; Mueller, R. H.; Willard, A. K. J. Am. Chem. Soc. 1976, 98, 2868-2877.

(b) Rathke, M. W.; Sullivan, D. F. Synth. Commun. 1973, 3, 67-72.

81. (a) Harvey, R. G.; Abu-shqara, E.; Yang, C. X. J. Org. Chem. 1992, 57, 6313-6317. (b) Muzart, J. Tetrahedron Lett. 1987, 28, 2131-2132. 
82. (a) Yang, C. X.; Harvey, R. G. Polycyclic Aromat. Compd. 1992, 2, 229-233. (b) Harvey, R. G. Polycyclic Aromatic Hydrocarbons; Wiley: New York, 1997; pp 336-337.

83. The structure was established by X-ray structure analysis (Figure 12).

84. Yoshida, M.; Kadokura, A.; Minabe, M. Bull. Chem. Soc. Jpn. 1980, 53, 1179-1180.

85. The structure was established by X-ray structure analysis (Figure 14).

86. (a) Klemm, L. H.; Shabtai, J.; Taylor, D. R. J. Org. Chem. 1968, 33, 1480-1488. (b) Zimmerman, H. E.; Factor, R. E. J. Am. Chem. Soc. 1980, 102, 3538-3548.

87. Lemmen, P.; Lenoir, D. Chem. Ber. 1984, 117, 2300-2313.

88. For reviews, see: (a) Meurer, K. P.; Vögtle, F. Top. Curr. Chem. 1985, 127, 1-76. (b) Hopf, H. Classics in Hydrocarbon Chemistry, Wiley-VCH, Weinheim, 2000, p. 321-330. (c) Laarhoven, W. H.; Prinsen, W. J. C. Top. Curr. Chem. 1984, 125, 63-130. (d) Martin, R. H. Angew. Chem. Int. Ed. 1974, 13, 649-660. For highlights, see: (e) Urbano, A. Angew. Chem. Int. Ed. 2003, 42, 3986-3989. (f) Schmuck, C. Angew. Chem. Int. Ed. 2003, 42, 2448-2452.

89. Janke, R. H.; Haufe, G.; Würthwein, E.-U.; Borkent, J. H. J. Am. Chem. Soc. 1996, 118, 6031-6035.

90. (a) Sato, I.; Yamashima, R.; Kadowaki, K.; Yamamoto, J.; Shibata, T.; Soai, K. Angew. Chem. Int. Ed. 2001, 40, 1096-1098. (b) Reetz, M. T.; Beuttenmüller, E. W.; Goddard, R. Tetrahedron Lett. 1997, 38, 3211-3214. (c) Terfort, A.; Görls, H.; Brunner, H. Synthesis 1997, 79-86. (d) Dreher, S. D.; Katz, T. J.; Lam, K.-C.; Rheingold, A. L. J. Org. Chem. 2000, 65, 815-822. (e) Fox, J. M.; Katz, T. J. J. Org. Chem. 1999, 64, 302-305. (f) Tanaka, K.; Osuga, H.; Shogase, Y.; Suzuki, H. Tetrahedron Lett. 1995, 36, 915-918. (g) Tanaka, K.; Kitahara, Y.; Suzuki, H.; Osuga, H. Tetrahedron Lett. 1996, 37, 5925-5928. 
91. (a) Honzawa, S.; Okubo, H.; Anzai, S.; Yamaguchi, M.; Tsumoto, K.; Kumagai, I. Bioorg. Med. Chem. 2002, 10, 3213-3218. (b) Kim, Y. H. Science 1981, 213, 1379-1381. (c) Ihara, H.; Nakanishi, N.; Sagawa, T.; Hirayama, C.; Sakurai, T.; Kinoshita, T.; Tsujita, Y. Chem. Lett. 1998, 963-964. (d) Nakagawa, H.; Yoshida, M.; Koborl, Y.; Yamada, K.-I. Chirality 2003, 15, 703-708. (e) Dipple, A.; Pigott, M. A.; Agarwal, S. K.; Yagi, H.; Sayer, J. M.; Jerina, D. M. Nature 1987, 327, 535-536.

92. (a) Nuckolls, C.; Katz, T. J. J. Am. Chem. Soc. 1998, 120, 9541-9544. (b) Lovinger, A. J.; Nuckolls, C.; Katz, T. J. J. Am. Chem. Soc. 1998, 120, 264-268. (c) Dai, Y.; Katz, T. J. J. Org. Chem. 1997, 62, 1274-1285.

93. (a) Verbiest, T.; Elshocht, S. V.; Kauranen, M.; Hellemans, L.; Snauwaert, J.; Nuckolls, C.; Katz, T. J.; Persoons, A. Science 1998, 282, 913-915. (b) Deussen, H.-J.; Hendrickx, E.; Boutton, C.; Krog, D.; Clays, K.; Bechgaard, K.; Persoons, A.; Bjørnholm, T. J. Am. Chem. Soc. 1996, 118, 6841-6852. (c) Maiorana, S.; Papagni, A.; Licandro, E.; Annunziata, R.; Paravidino, P.; Perdicchia, D.; Giannini, C.; Bencini, M.; Clays, K.; Persoons, A. Tetrahedron 2003, 59, 6481-6488. (d) Clays, K.; Wostyn, K.; Persoons, A.; Maiorana, S.; Papagni, A.; Daul, C. A.; Weber, V. Chem. Phys. Lett. 2003, 372, 438-442. (e) Chen, C.-T.; Chou, Y.-C. J. Am. Chem. Soc. 2000, 122, 7662-7672. (f) Nishida, J.-I.; Suzuki, T.; Ohkita, M.; Tsuji, T. Angew. Chem. Int. Ed. 2001, 40, 3251-3254. (g) Grimme, S.; Harren, J.; Sobanski, A.; Vögtle, F. Eur. J. Org. Chem. 1998, 1491-1509. (h) Verbiest, T.; Elshocht, S. V.; Persoons, A.; Nuckolls, C.; Phillips, K. E.; Katz, T. J. Langmuir 2001, 17, 4685-4687. (i) Verbiest, T.; Sioncke, S.; Persoons, A.; Vyklický, L.; Katz, T. J. Angew. Chem. Int. Ed. 2002, 41, 3882-3884. (j) Nuckolls, C.; Shao, R.; Jang, W.-G.; Clark, N. A., Walba, D. M.; Katz, T. J. Chem. Mater. 2002, 14, 773-776. 
94. (a) Fox, J. M.; Katz, T. J.; Elshocht, S. V.; Verbiest, T.; Kauranen, M.; Persoons, A.; Thongpanchang, T.; Krauss, T.; Brus, L. J. Am. Chem. Soc. 1999, 121, 3453-3459. (b) Katz, T. J. Angew. Chem. Int. Ed. 2000, 39, 1921-1923. (c) Phillips, K. E. S.; Katz, T. J.; Jockusch, S.; Lovinger, A. J.; Turro, N. J. J. Am. Chem. Soc. 2001, 123, 11899-11907.

95. (a) Kelly, T. R.; De Silva, H.; Silva, R. A. Nature 1999, 401, 150-152. (b) Kelly, T. R.; Sestelo, J. P.; Tellitu, I. J. Org. Chem. 1998, 63, 3655-3665.

96. (a) Armstrong, R. N.; Ammon, H. L.; Darnow, J. N. J. Am. Chem. Soc. 1987, 109, 2077-2082. (b) Cosmo, R.; Hambley, T. W.; Sternhell, S. J. Org. Chem. 1987, 52, 3119-3123. (c) Imashiro, F.; Saika, A.; Taira, Z. J. Org. Chem. 1987, 52, 5727-5729. (d) Tinnemans, A. H. A.; Laarhoven, W. H. J. Chem. Soc., Perkin Trans. 2 1976, 1115-1120. (e) Tinnemans, A. H. A.; Laarhoven, W. H. J. Am. Chem. Soc. 1974, 96, 4617-4622.

97. (a) Floyd, A. J.; Dyke, S. F.; Ward, S. E. Chem. Rev. 1976, 76, 509-562. (b) Brown, W. G.; Bluestein, B. J. Am. Chem. Soc. 1940, 62, 3256-3257. (c) Collins, C. J.; Hess, D. N.; Mayor, R. H.; Toffel, G. M.; Jones, A. R. J. Am. Chem. Soc. 1953, 75, 397-402. (d) Benjamin, B. M.; Collins, C. J. J. Am. Chem. Soc. 1953, 75, 402-405. (e) Collins, C. J.; Ciereszko, L. S.; Burr, J. G., Jr. J. Am. Chem. Soc. 1953, 75, 405-408.

98. (a) Newman, M. S.; Whitehouse, H. S. J. Am. Chem. Soc. 1949, 71, 3664-3667. (b) Munday, R.; Sutherland, I. O. J. Chem. Soc. B 1968, 80-84.

99. (a) Newman, M. S.; Lilje, K. C. J. Org. Chem. 1979, 44, 4944-4946. (b) Karnes, H. A.; Kybett, B. D.; Wilson, M. H.; Margrave, J. L.; Newman, M. S. J. Am. Chem. Soc. 1965, 87, $5554-5558$.

100. (a) Mannschreck, A.; Gmahl, E.; Burgemeister, T.; Kastner, F.; Sinnwell, V. Angew. Chem. Int. Ed. Engl. 1988, 27, 270-271. (b) Grimme, S.; Pischel, I.; Nieger, M.; Vögtle, F. J. Chem. 
Soc., perkin Trans. 2 1996, 2771-2774. (c) Fritsch, R.; Hartmann, E.; Andert, D.; Mannschreck, A. Chem. Ber. 1992, 125, 849-855. (d) Scherübl, H.; Fritzsche, U.; Mannschreck, A. Chem. Ber. 1984, $117,336-343$.

101. MacDowell, D. W. H.; Childers, R. L. J. Org. Chem. 1962, 27, 2630-2631.

102. (a) Tinnemans, A. H. A.; Laarhoven, W. H. Tetrahedron 1979, 35, 1537-1541. (b) Tinnemans, A. H. A.; Laarhoven, W. H. Tetrahedron Lett. 1973, 817-820.

103. (a) Estévez, J. C.; Villaverde, M. C.; Estévez, R. J.; Castedo, L. Tetrahedron 1993, 49, 2783-2790. (b) Estévez, J. C.; Estévez, R. J.; Castedo, L. Tetrahedron Lett. 1992, 33, 6883-6884. (c) Kessar, S. V.; Sood, R.; Nadir, U. K.; Singh, M. Chem. Commun. 1969, 316. (d) Yoshikawa, E.; Yamamoto, Y. Angew. Chem. Int. Ed. 2000, 39, 173-175. (e) Radhakrishnan, K. V.; Yoshikawa, E.; Yamamoto, Y. Tetrahedron Lett. 1999, 40, 7533-7535. (f) Leardini, R.; Nanni, D.; Tundo, A.; Zanardi, G. Synthesis 1988, 333-335.

104. (a) Flammang-Barbieux, M.; Nasielski, J.; Martin, R. H. Tetrahedron Lett. 1967, 743-744. (b) Moradpour, A.; Kagan, H.; Baes, M.; Morren, G.; Martin, R. H. Tetrahedron 1975, 31, 2139-2143. (c) Martin, R. H.; Baes, M. Tetrahedron 1975, 31, 2135-2137. (d) Hassine, B. B.; Gorsane, M.; Pecher, J. Bull. Soc. Chim. Belg. 1985, 94, 597-603. (e) Liu, L.; Yang, B.; Katz, T. J.; Poindexter, M. K. J. Org. Chem. 1991, 56, 3769-3775. (f) Frimer, A. A.; Kinder, J. D.; Youngs, W. J.; Meador, M. A. B. J. Org. Chem. 1995, 60, 1658-1664. (g) Fox, J. M.; Lin, D. J. Org. Chem. 1998, 63, 2031-2038. (h) Martin, R. H.; Marchant, M.-J.; Baes, M. Helv. Chim. Acta 1971, 54, 358-360.

105. (a) Liu, L.; Katz, T. J. Tetrahedron Lett. 1990, 31, 3983-3986. (b) Willmore, N. D.; Liu, L.; Katz, T. J. Angew. Chem. Int. Ed. Engl. 1992, 31, 1093-1095. 
106. (a) Dubois, F.; Gingras, M. Tetrahedron Lett. 1998, 39, 5039-5040. (b) Gingras, M.; Dubois, F. Tetrahedron Lett. 1999, 40, 1309-1312.

107. (a) Harrowven, D. C.; Nunn, M. I. T.; Fenwick, D. R. Tetrahedron Lett. 2002, 43, 3189-3191. (b) Harrowven, D. C.; Nunn, M. I. T.; Fenwick, D. R. Tetrahedron Lett. 2002, 43, $7345-7347$.

108. (a) Teplý, F.; Stará, I. G.; Starý, I.; Kollárovič, A.; Šaman, D.; Rulíšek, L.; Fiedler, P. J. Am. Chem. Soc. 2002, 124, 9175-9180. (b) Stará, I. G.; Starý, I.; Kollárovič, A.; Teplý, F.; Šaman, D.; Fiedler, P. Collect. Czech. Chem. Commun. 2003, 68, 917-930. (c) Teplý, F.; Stará, I. G.; Starý, I.; Kollárovič, A.; Šaman, D.; Vyskočil, Š.; Fiedler, P. J. Org. Chem. 2003, 68, $5193-5197$.

109. (a) Peña, D.; Cobas, A.; Pérez, D.; Guitián, E.; Castedo, L. Org. Lett. 2003, 5, 1863-1866. (b) Peña, D.; Pérez, D.; Guitián, E.; Castedo, L. Org. Lett. 1999, 1, 1555-1557.

110. (a) Mikeš, F.; Boshart, G.; Gil-Av, E. J. Chem. Soc., Chem. Commun. 1976, 99-100. (b) Nakagawa, H.; Ogashiwa, S.; Tanaka, H.; Yamada, K.; Kawazura, H. Bull. Chem. Soc. Jpn. 1981, 54, 1903-1904.

111. Thongpanchang, T.; Paruch, K.; Katz, T. J.; Rheingold, A. L.; Lam, K.-C.; Liable-Sands, L. J. Org. Chem. 2000, 65, 1850-1856.

112. (a) Carreño, M. C.; García-Cerrada, S.; Urbano, A. J. Am. Chem. Soc. 2001, 123, 7929-7930. (b) Carreño, M. C.; García-Cerrada, S.; Urbano, A. Chem. Eur. J. 2003, 9, 4118-4131. (c) Carreño, M. C.; García-Cerrada, S.; Sanz-Cuesta, M. J.; Urbano, A. Chem. Commun. 2001, 1452- 1453. (d) Carreño, M. C.; García-Cerrada, S.; Urbano, A. Chem. Commun. 2002, 1412-1413. 
113. (a) Ogawa, Y.; Toyama, M.; Karikomi, M.; Seki, K.; Haga, K.; Uyehara, T. Tetrahedron Lett. 2003, 44, 2167-2170. (b) Ogawa, Y.; Ueno, T.; Karikomi, M.; Seki, K.; Haga, K.; Uyehara, T. Tetrahedron Lett. 2002, 43, 7827-7829.

114. (a) Paruch, K.; Katz, T. J.; Incarvito, C.; Lam, K.-C.; Rhatigan, B.; Rheingold, A. L. J. Org. Chem. 2000, 65, 7602-7608. (b) Paruch, K.; Vyklický, L.; Wang, D. Z.; Katz, T. J.; Incarvito, C.; Zakharov, L.; Rheingold, A. L. J. Org. Chem. 2003, 68, 8539-8544.

115. Rajca, A.; Wang, H.; Pink, M.; Rajca, S. Angew. Chem. Int. Ed. 2000, 39, 4481-4483.

116. (a) Han, S.; Bond, A. D.; Disch, R. L.; Holmes, D.; Schulman, J. M.; Teat, S. J.; Vollhardt, K. P. C.; Whitener, G. D. Angew. Chem. Int. Ed. 2002, 41, 3223-3227. (b) Han, S.; Anderson, D. R.; Bond, A. D.; Chu, H. V.; Disch, R. L.; Holmes, D.; Schulman, J. M.; Teat, S. J.; Vollhardt, K. P. C.; Whitenner, G. D. Angew. Chem. Int. Ed. 2002, 41, 3227-3230.

117. Chong, J. M.; Lajoie, G.; Tjepkema, M. W. Synthesis 1992, 819-820.

118. (a) Smith, M. B.; March, J. March's Advanced Organic Chemistry, Wiley-Interscience, New York, 2001, p. 730-731. (b) Tashiro, M. Synthesis 1979, 921-936. (c) Tashiro, M.; Fukata, G. Org. Prep. Proced. Int. 1976, 8, 51-74. (d) Hofman, P. S.; Reiding, D. J.; Nauta, W. TH. Recl. Trav. Chim. Pays-Bas 1960, 79, 790-793.

119. See 4.3. Synthesis of 4,5-Di(1-naphthyl)phenanthrene.

120. 405 synthesized as described previously from benzophenone (277) and $\mathbf{6 0} .^{33}$

121. Bennett, G. B.; Nadelson, J.; Alden, L.; Jani, A. Org. Prep. Proced. Int. 1976, 8, 13-18. 


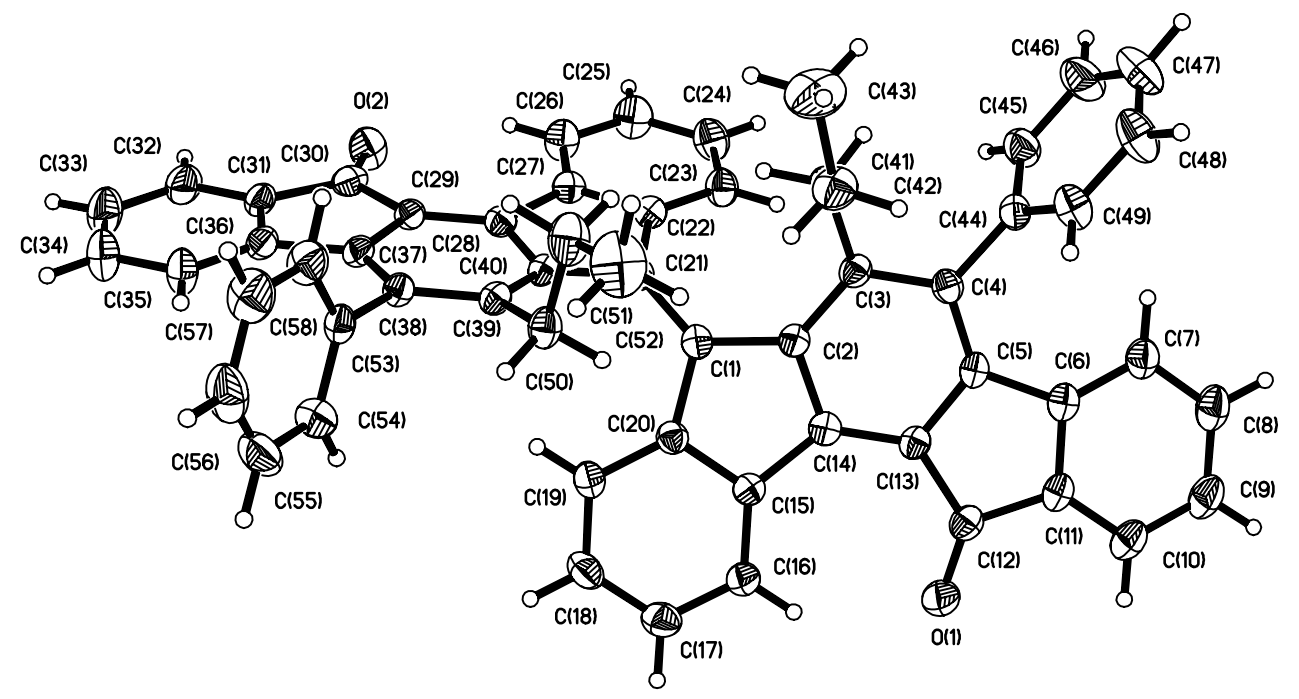

Figure 5b. ORTEP drawing of the crystal structure of 1,1'-dipropyl-9,9'-bifluorenylidene $\mathbf{1 6 5}$. 


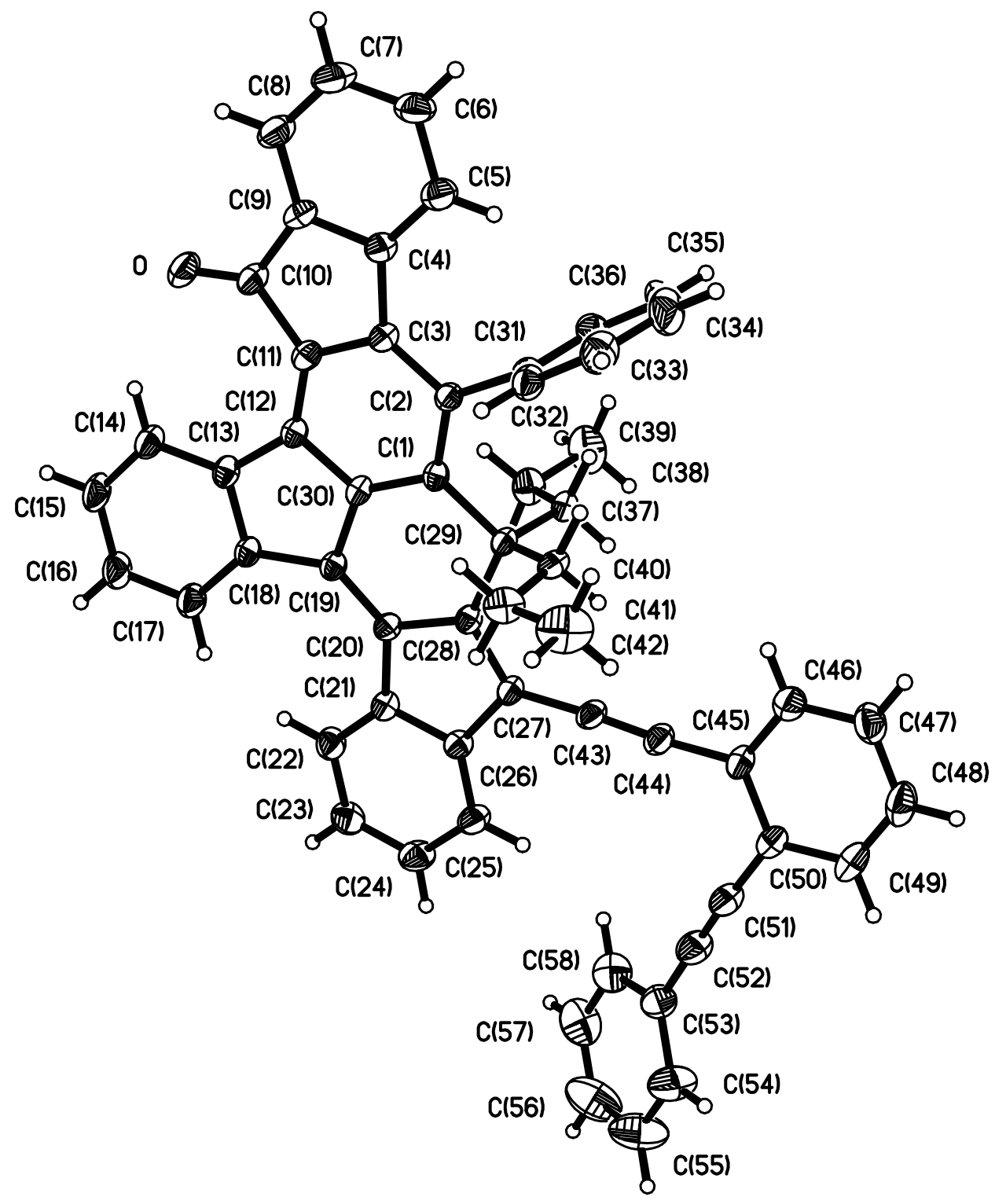

Figure 8. ORTEP drawing of the crystal structure of polycyclic compound $\mathbf{1 6 7 .}$ 


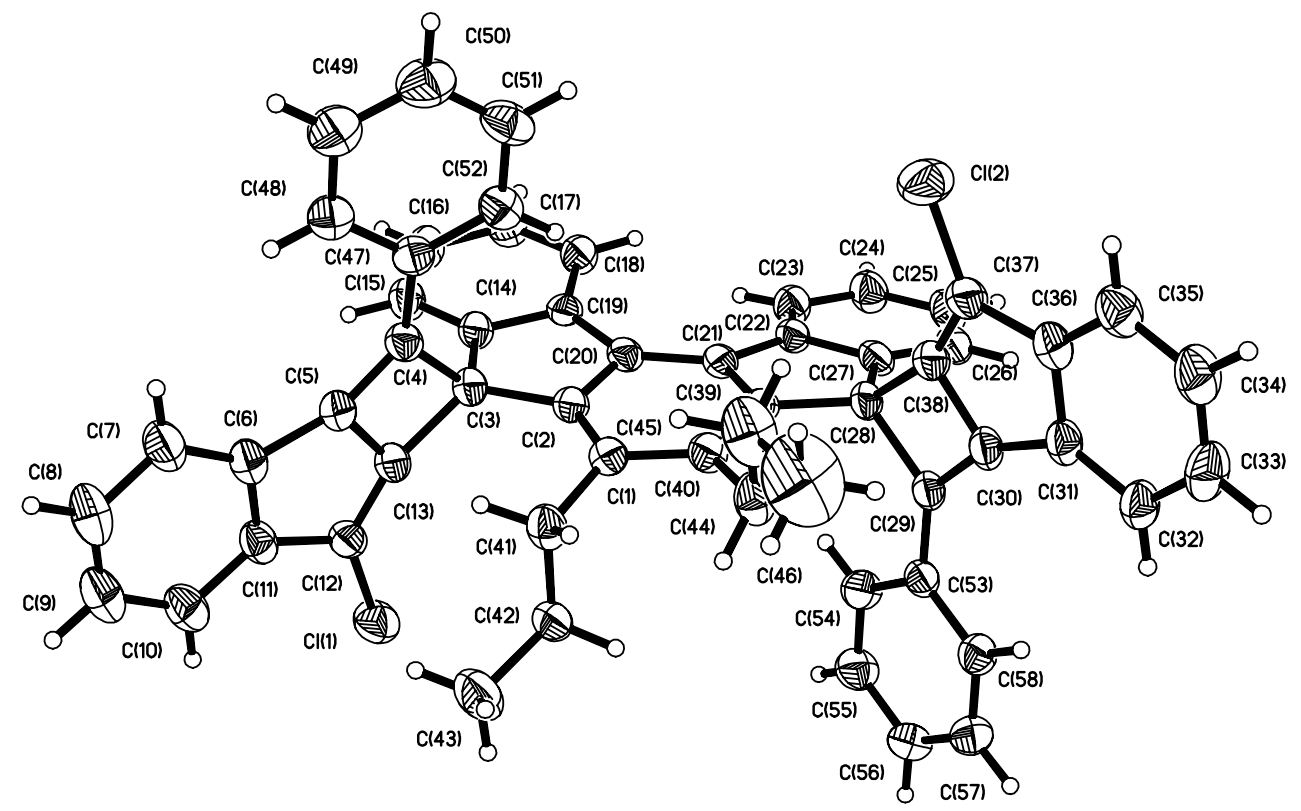

Figure 9. ORTEP drawing of the crystal structure of polycyclic compound 168.

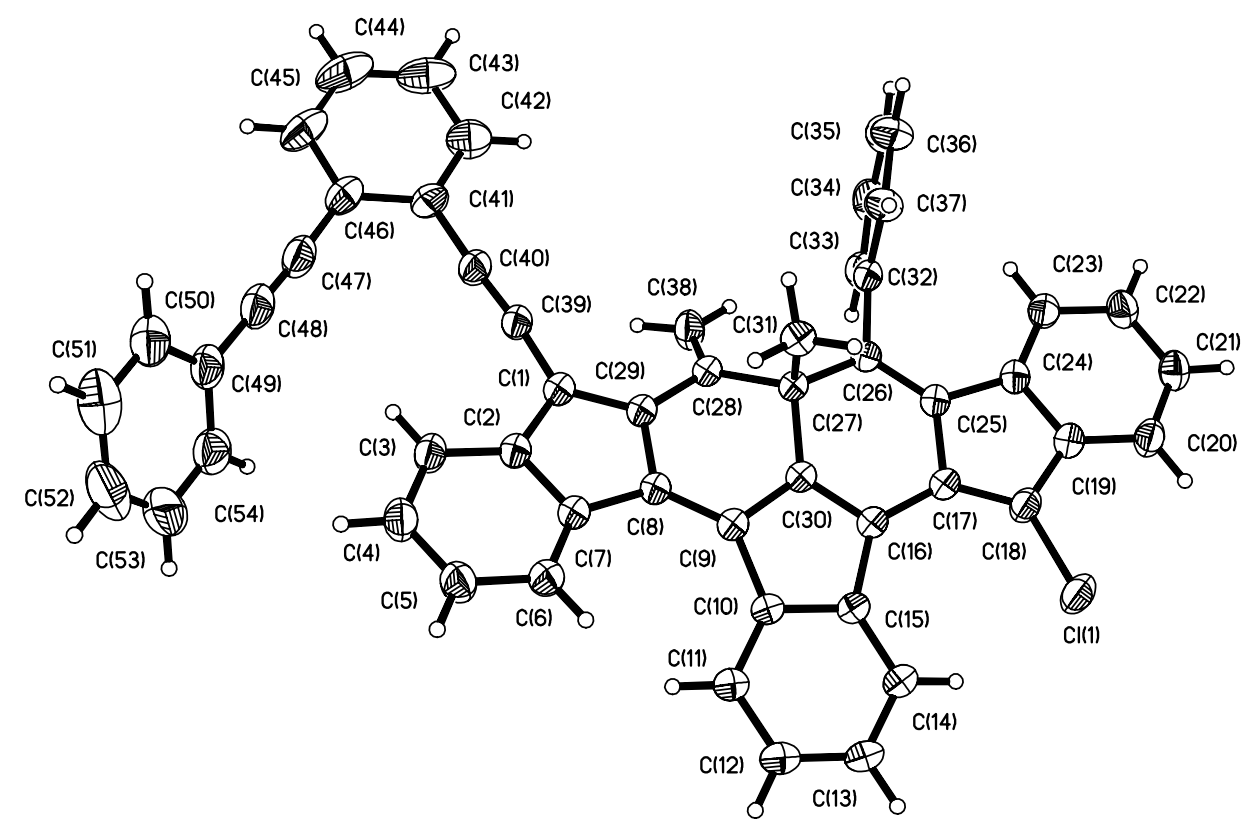

Figure 10. ORTEP drawing of the crystal structure of polycyclic compound 182. 


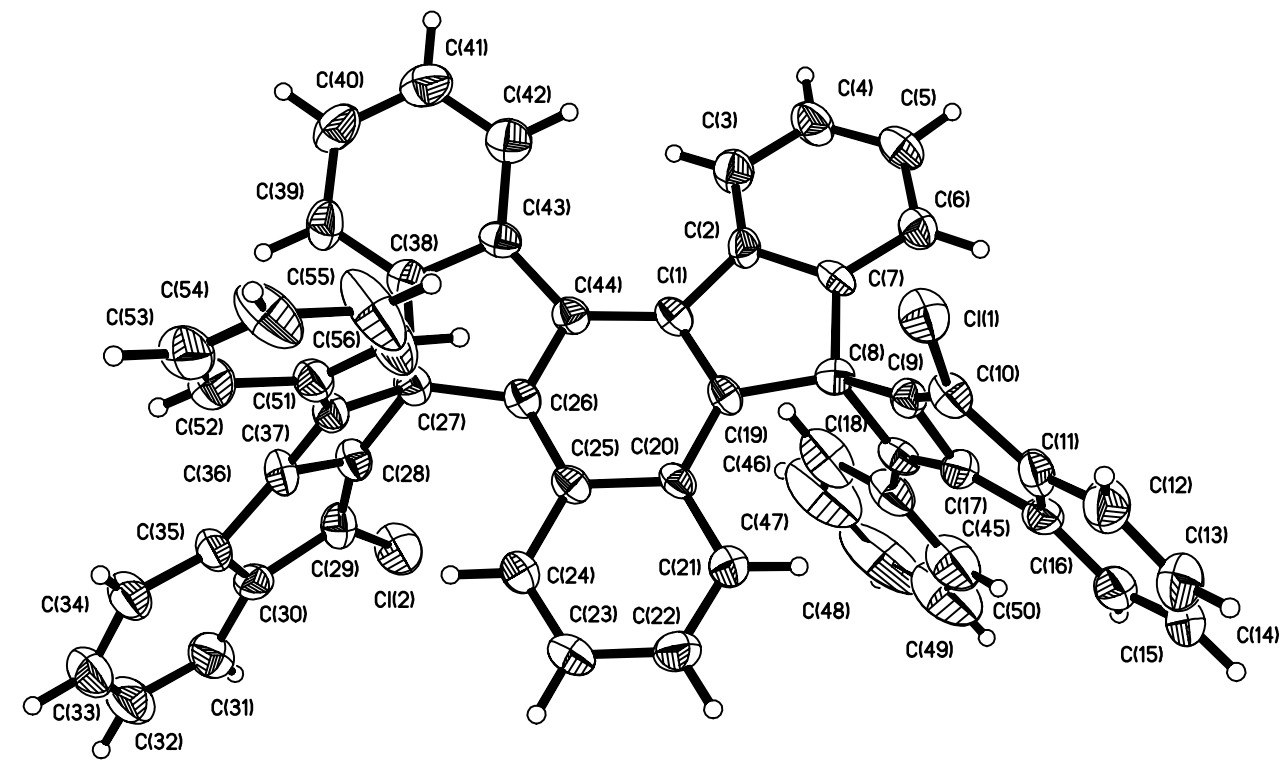

Figure 11. ORTEP drawing of the crystal structure of polycyclic compound $\mathbf{1 8 5}$. 


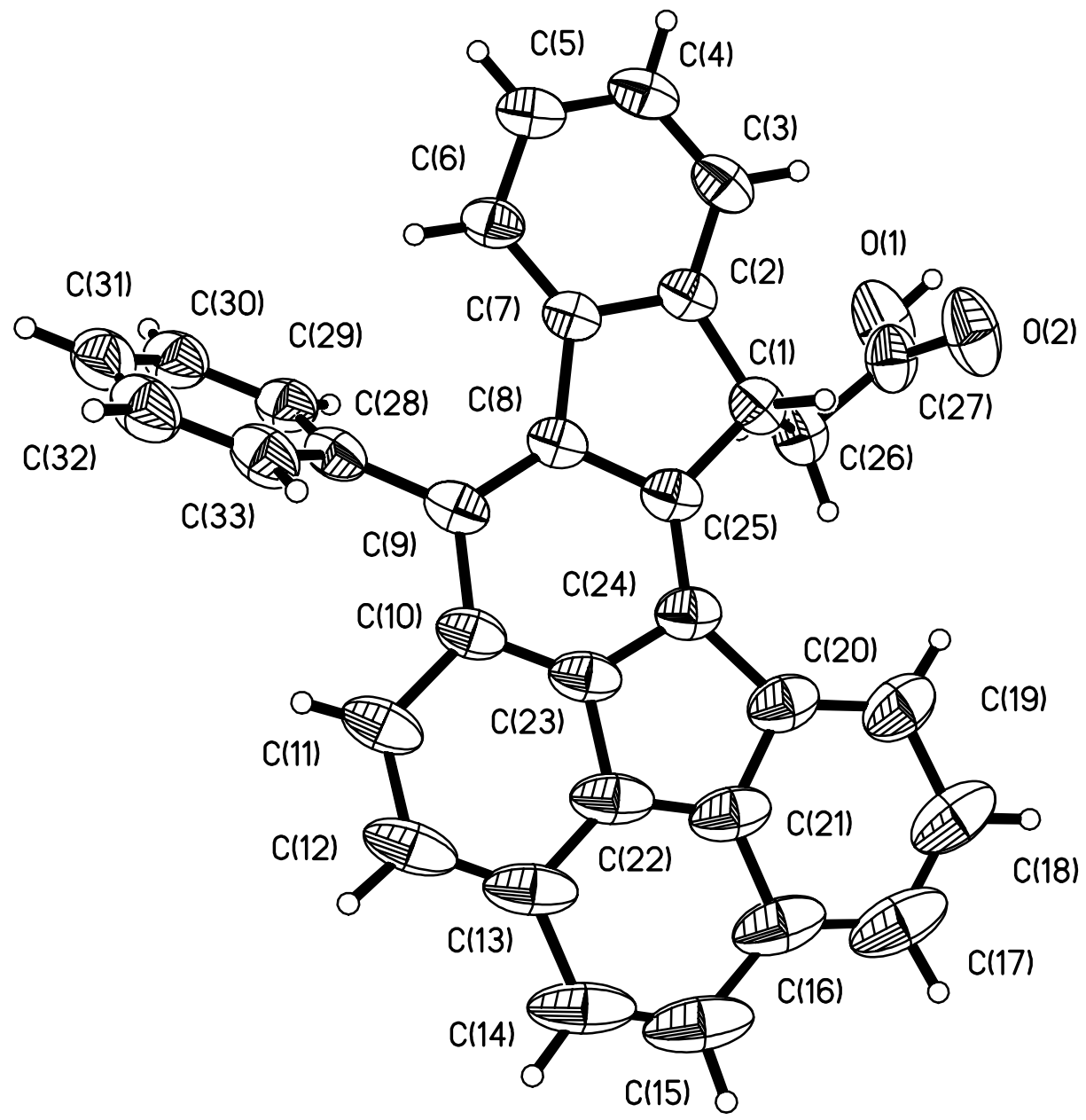

Figure 12. ORTEP drawing of the crystal structure of polycyclic carboxylic acid $\mathbf{2 8 3}$. 


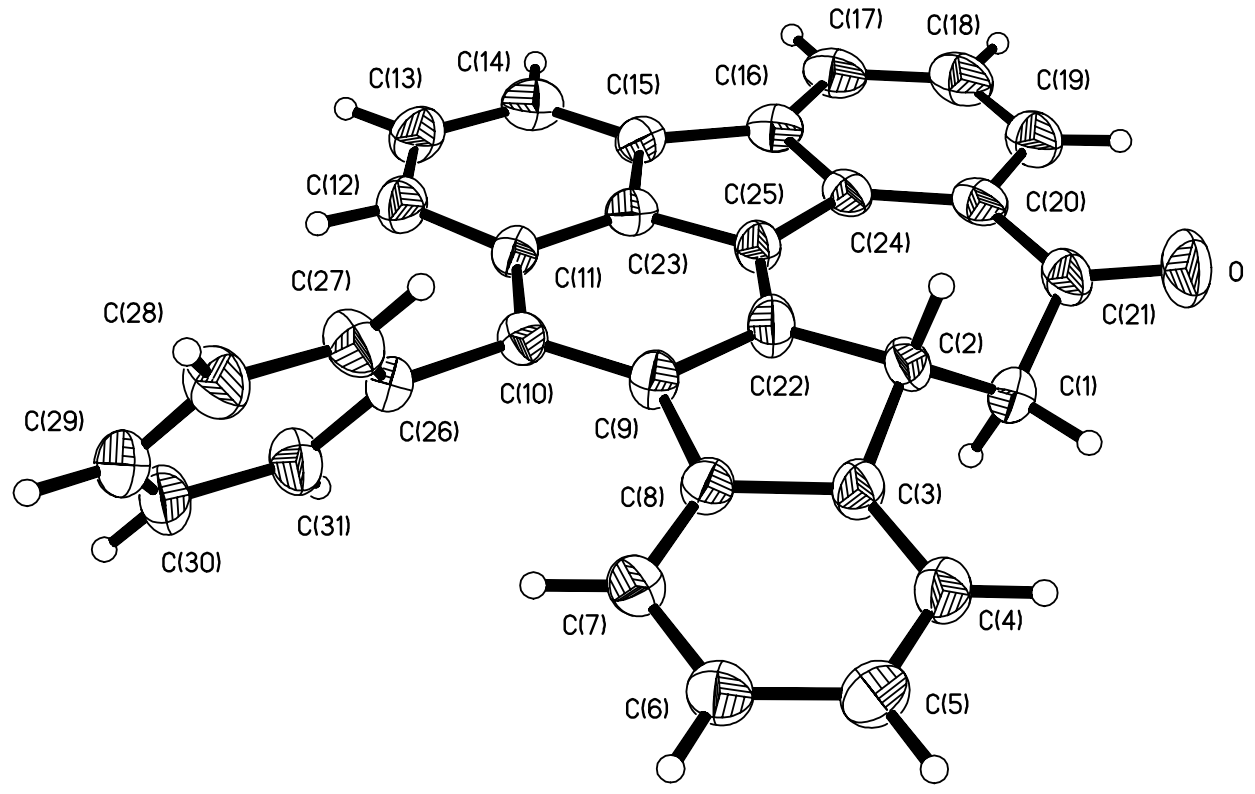

Figure 13. ORTEP drawing of the crystal structure of polycyclic ketone 287.

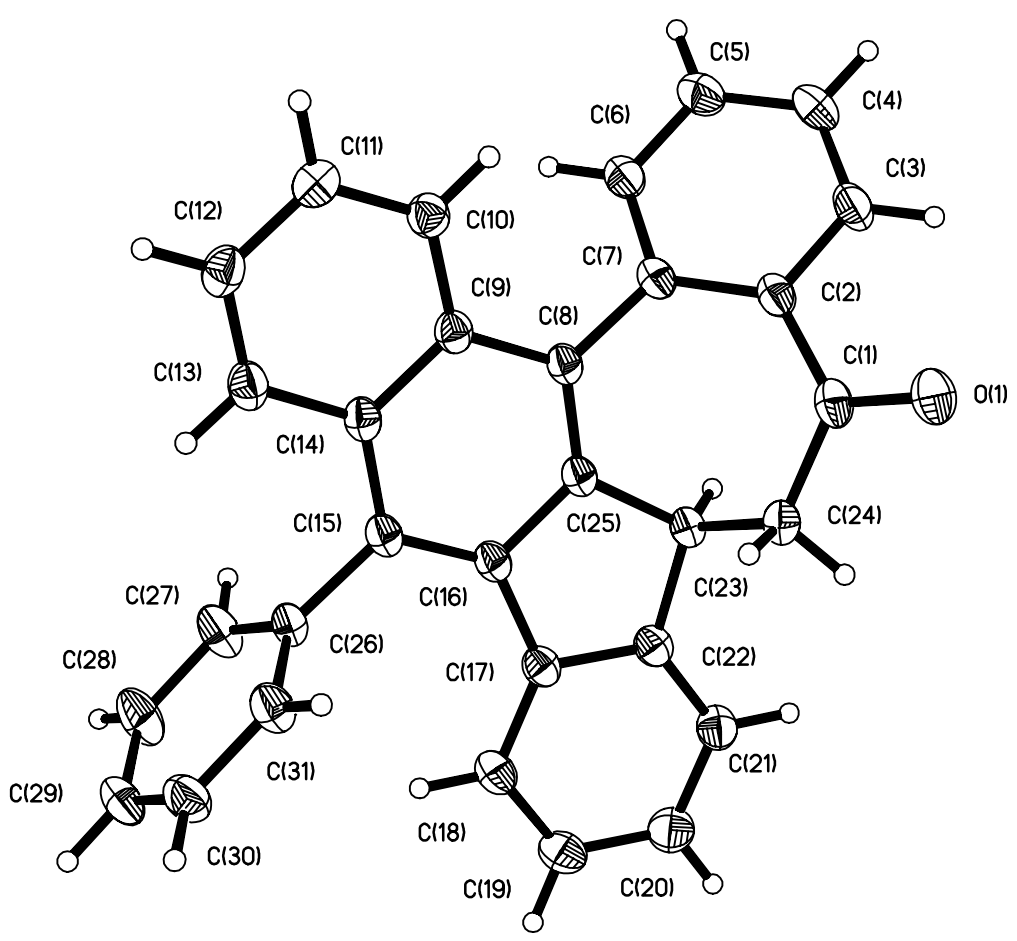

Figure 14. ORTEP drawing of the crystal structure of polycyclic ketone 291. 


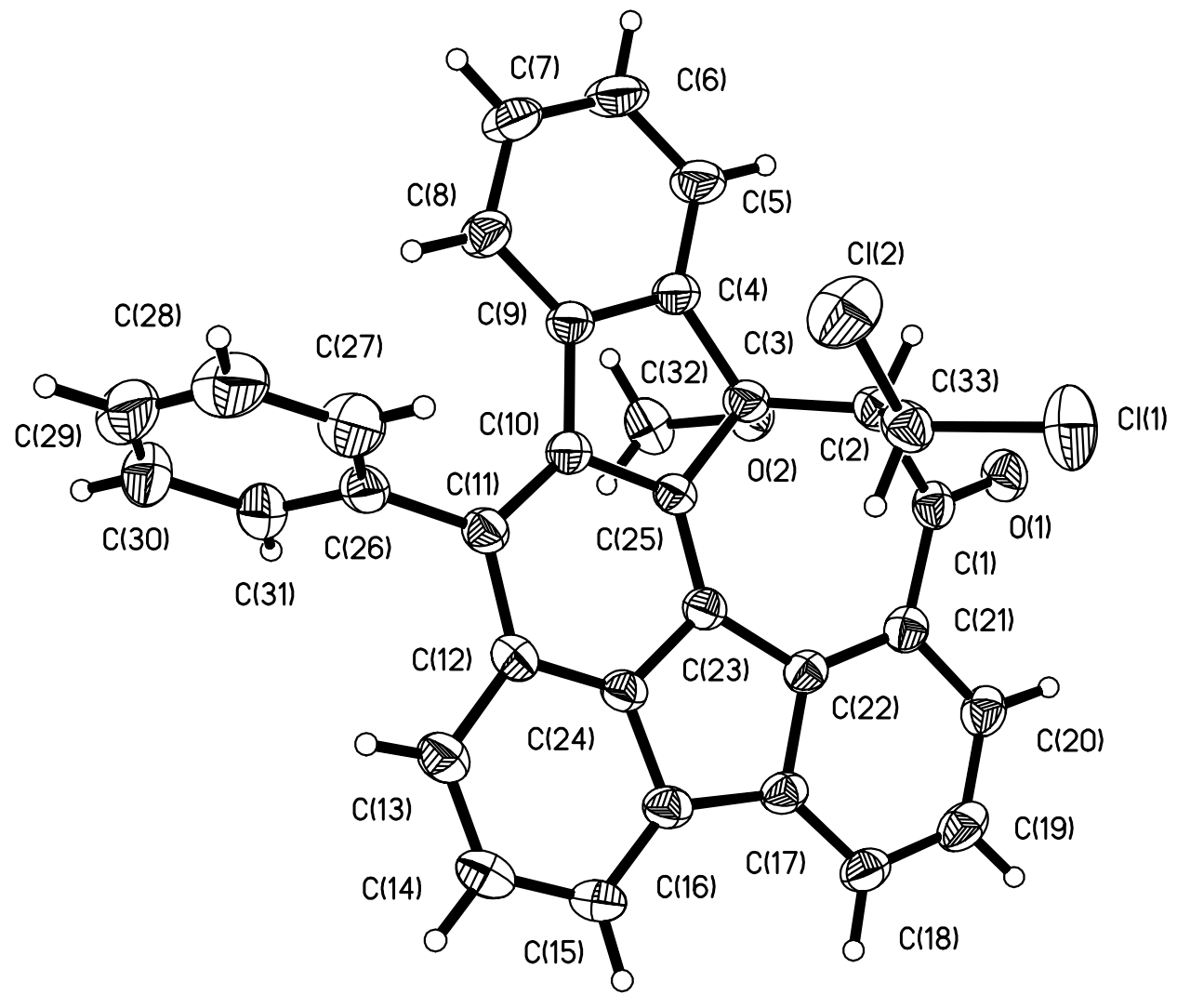

Figure 15. ORTEP drawing of the crystal structure of polycyclic compound $\mathbf{3 0 6}$. 


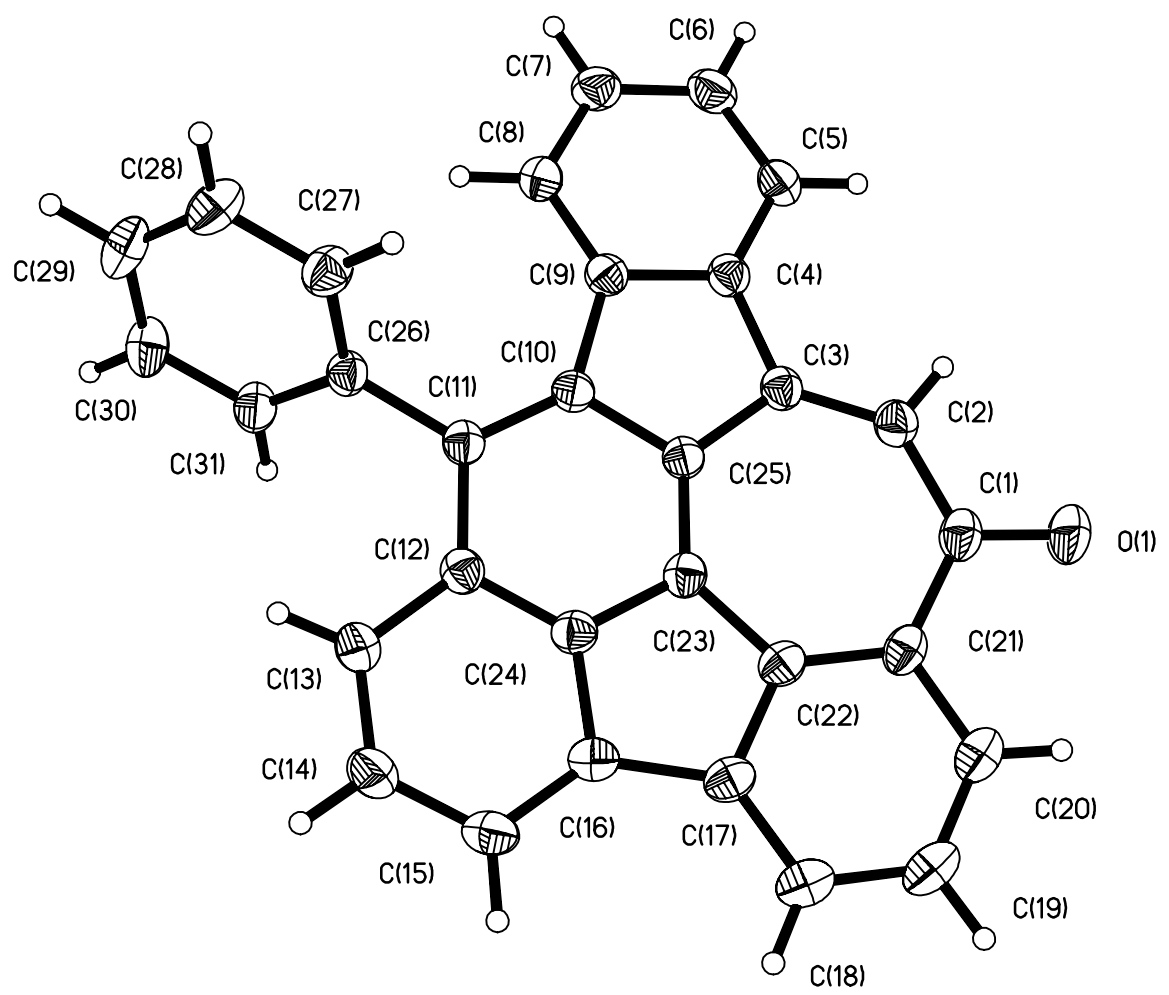

Figure 16. ORTEP drawing of the crystal structure of polycyclic compound $\mathbf{3 1 0}$.

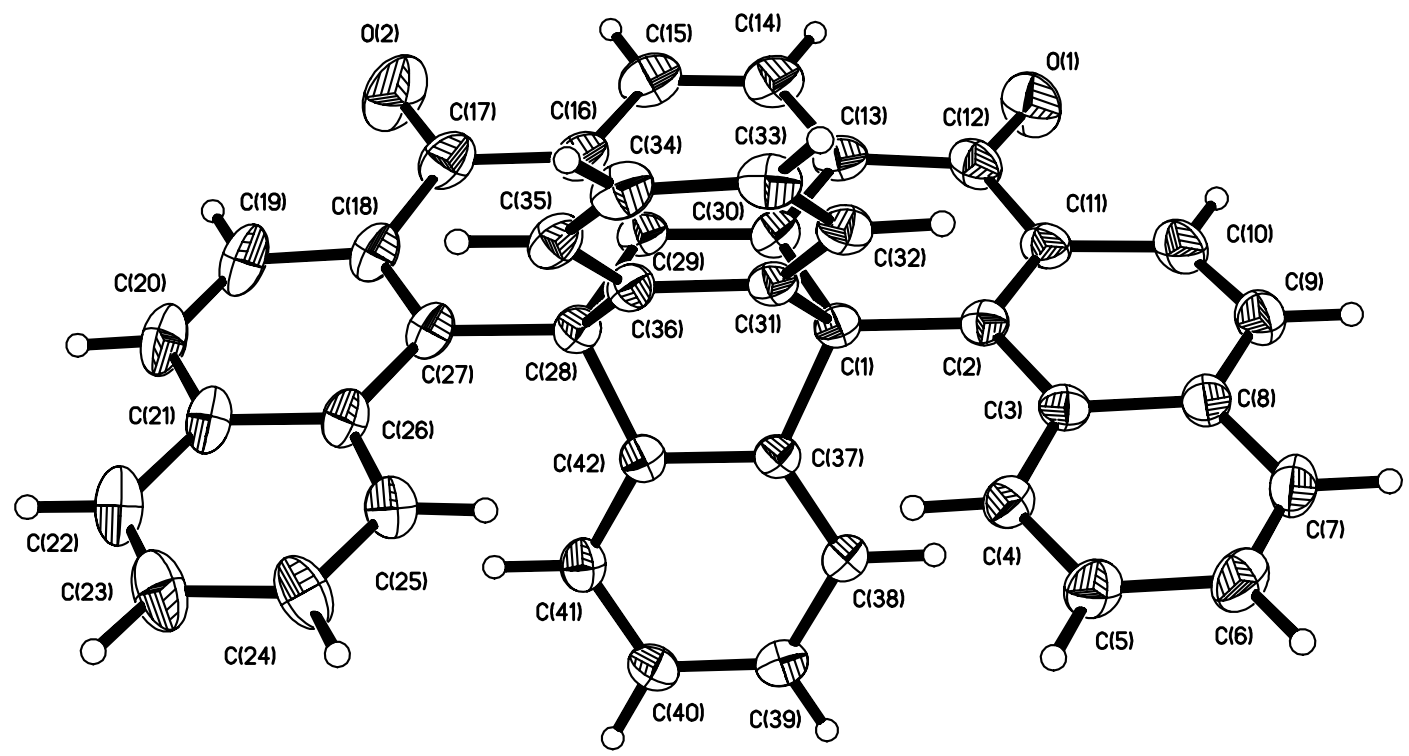

Figure 17. ORTEP drawing of the crystal structure of polycyclic compound $\mathbf{3 8 0}$. 

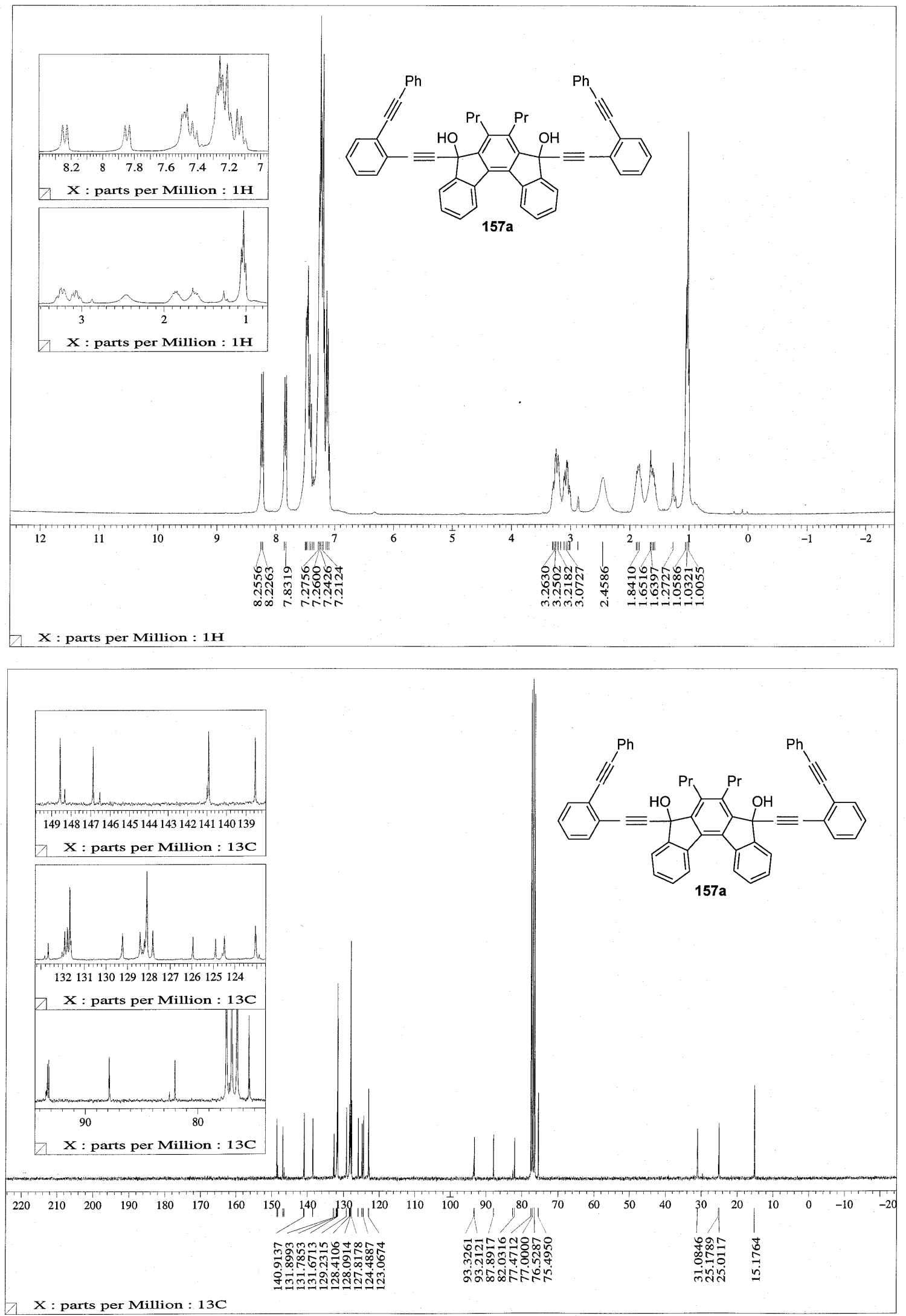

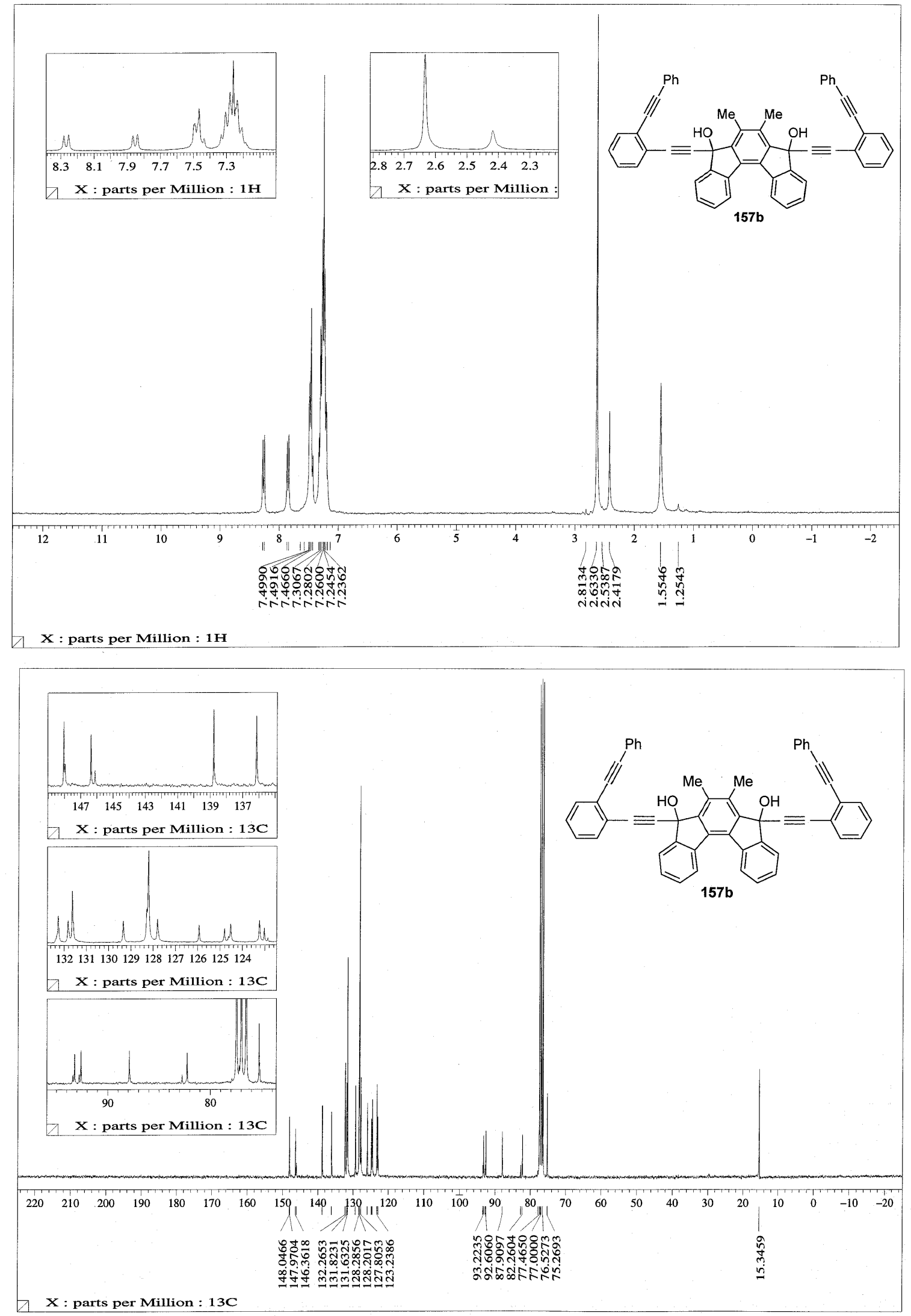

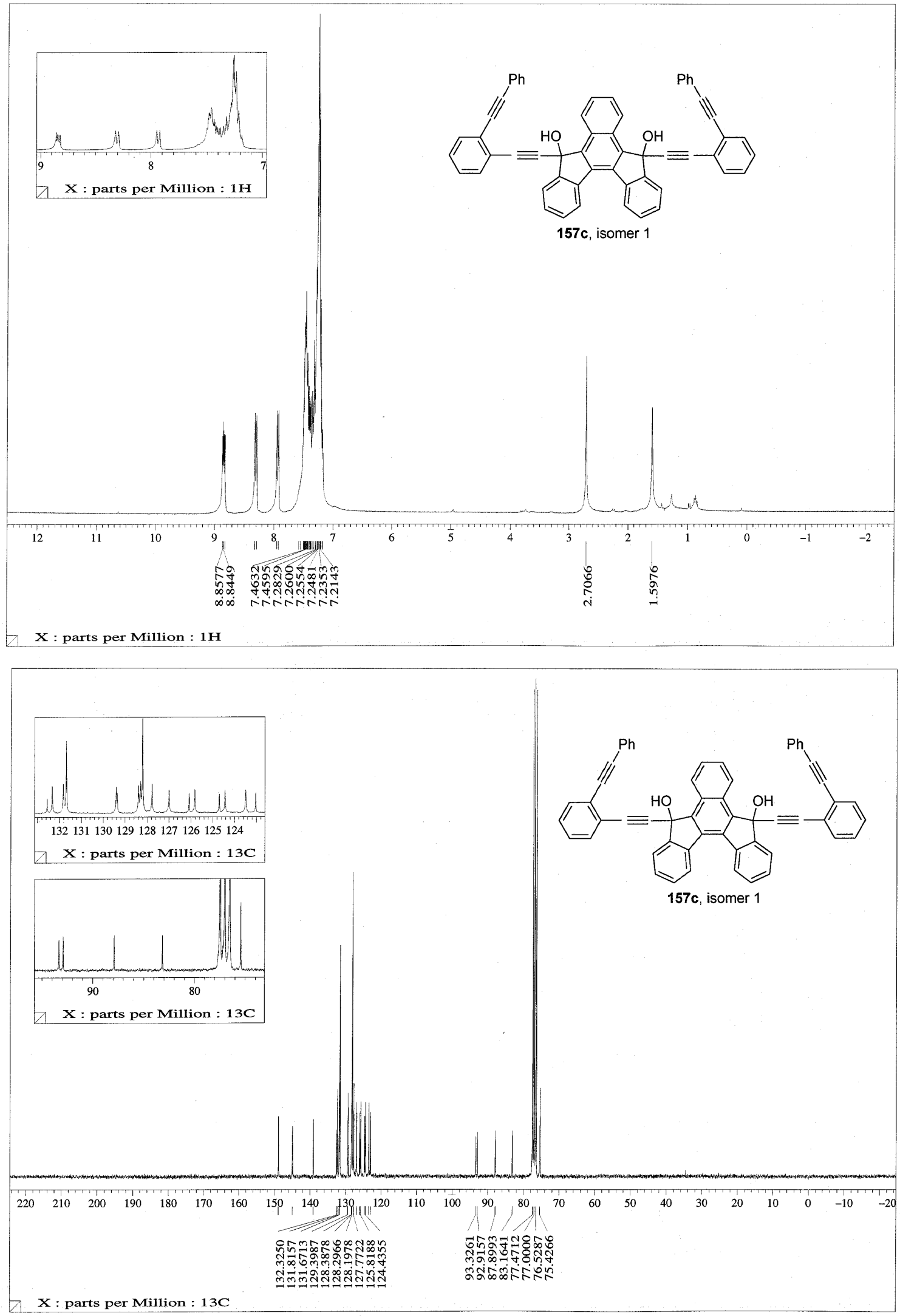

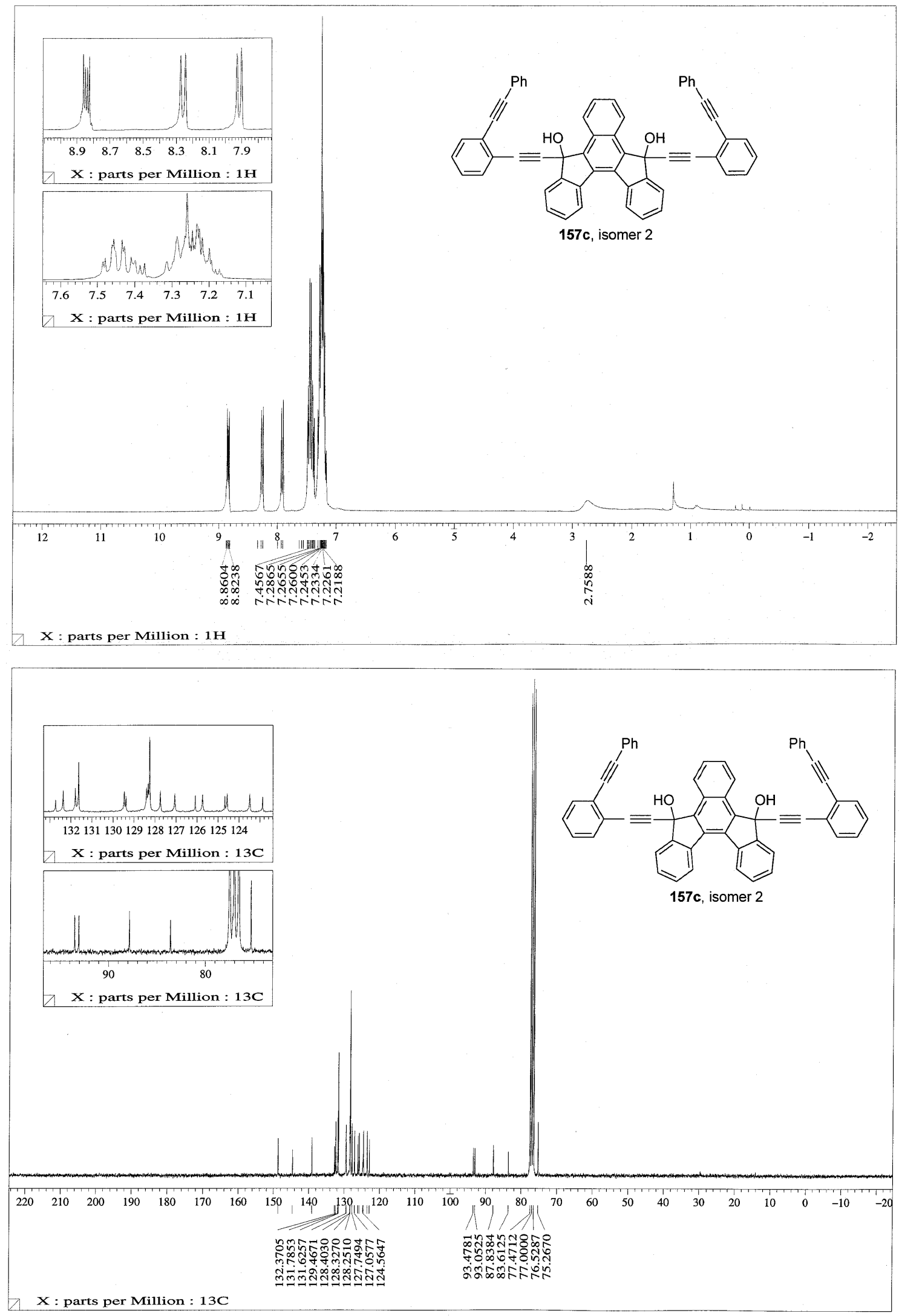

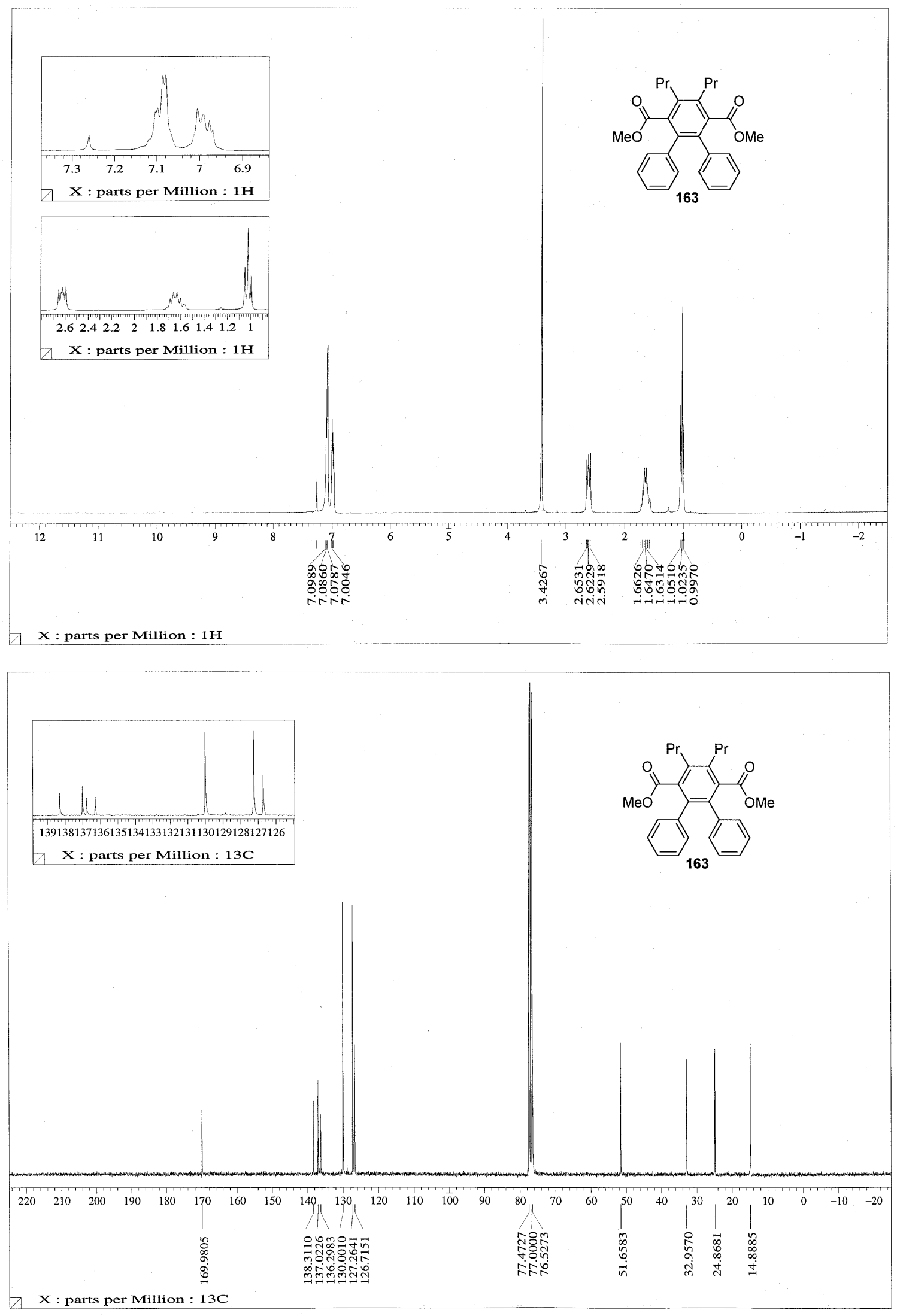

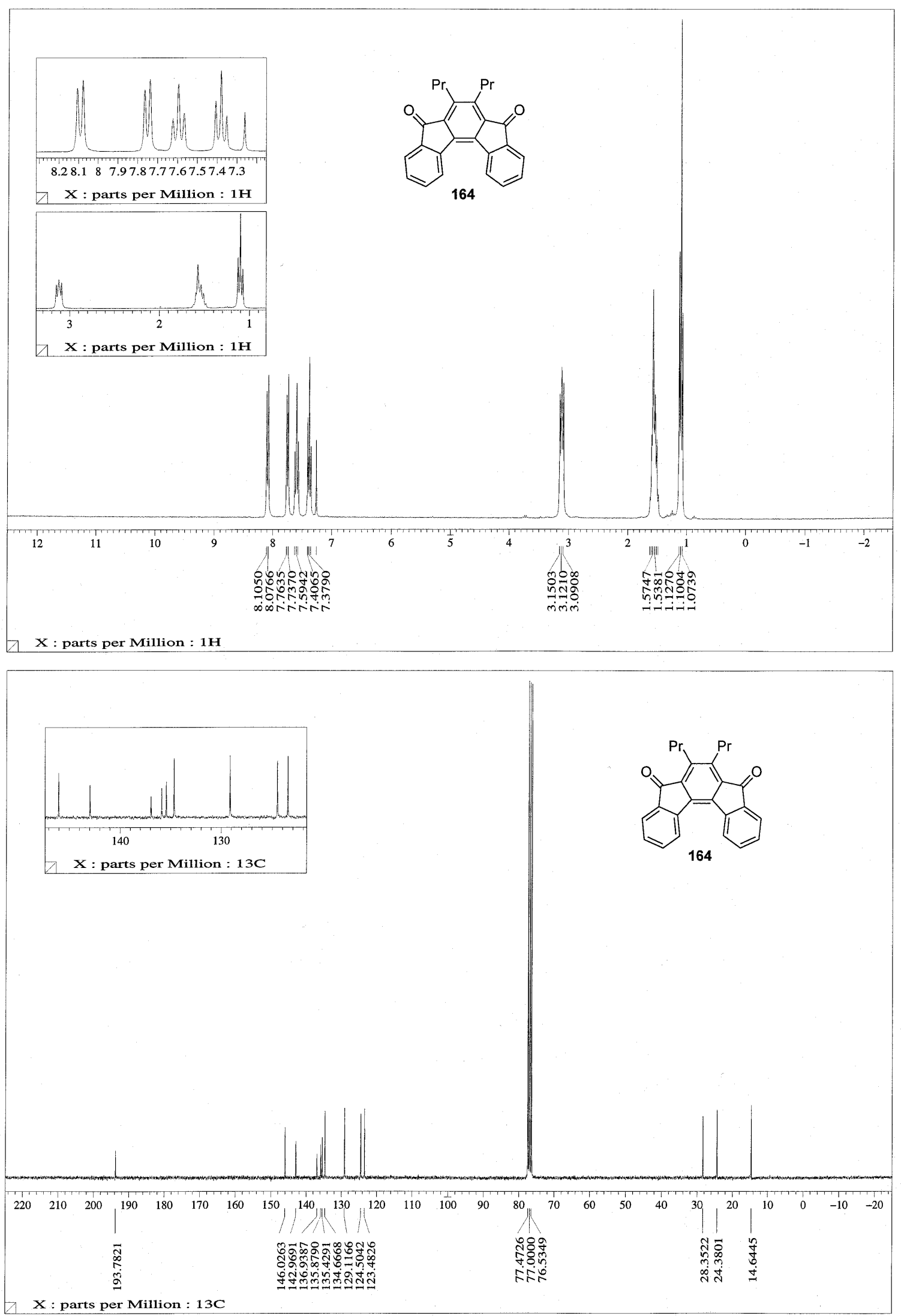

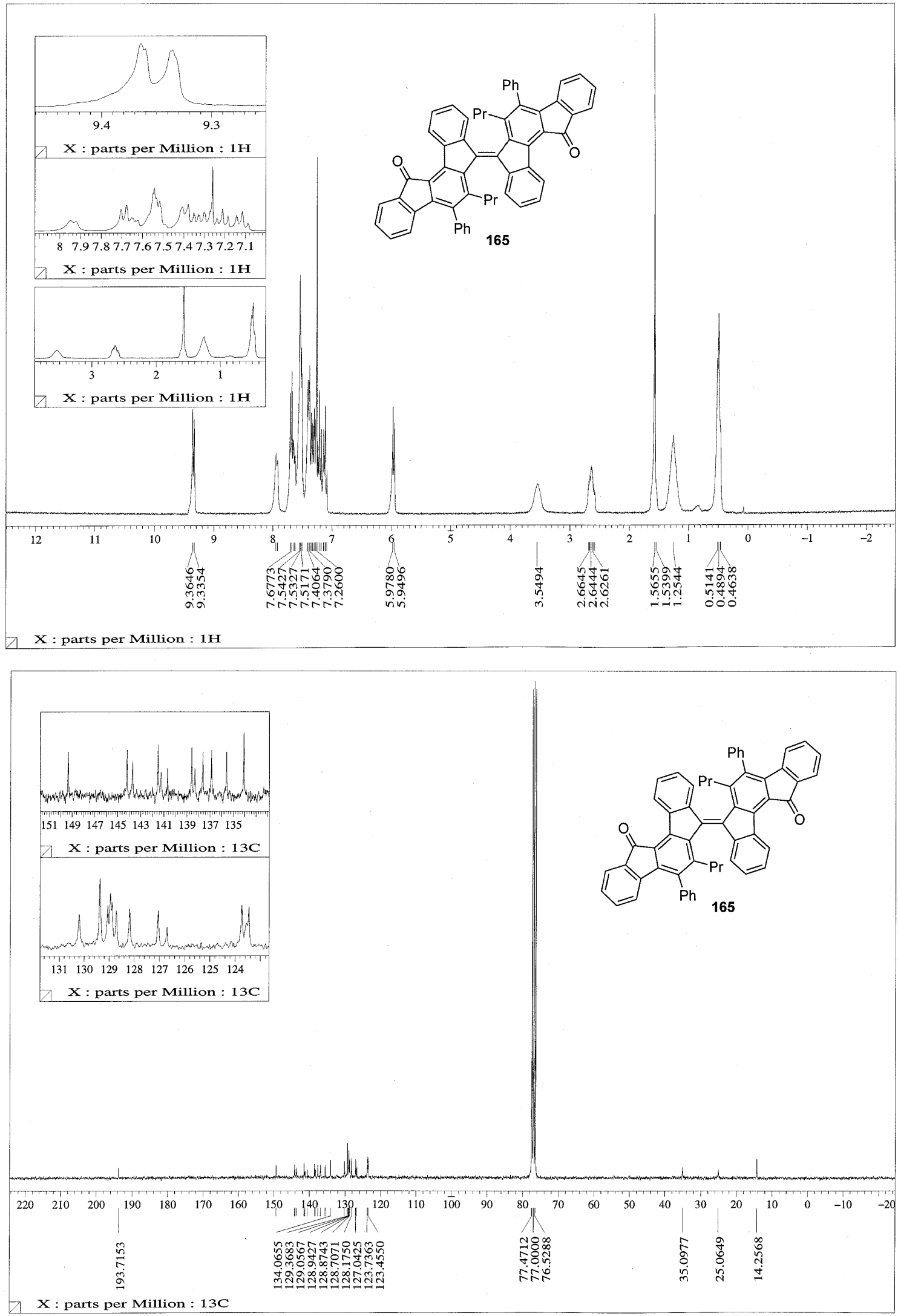


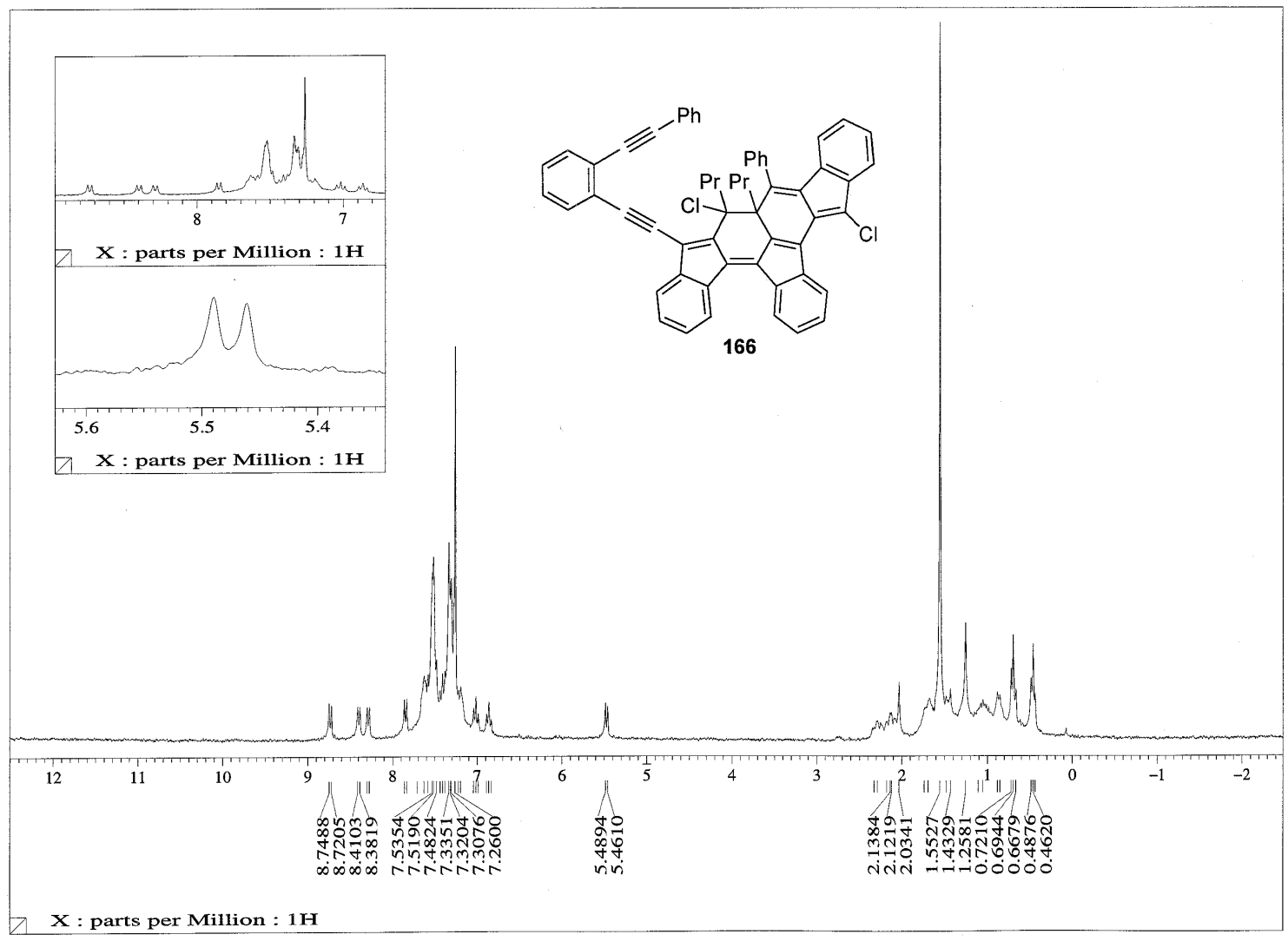



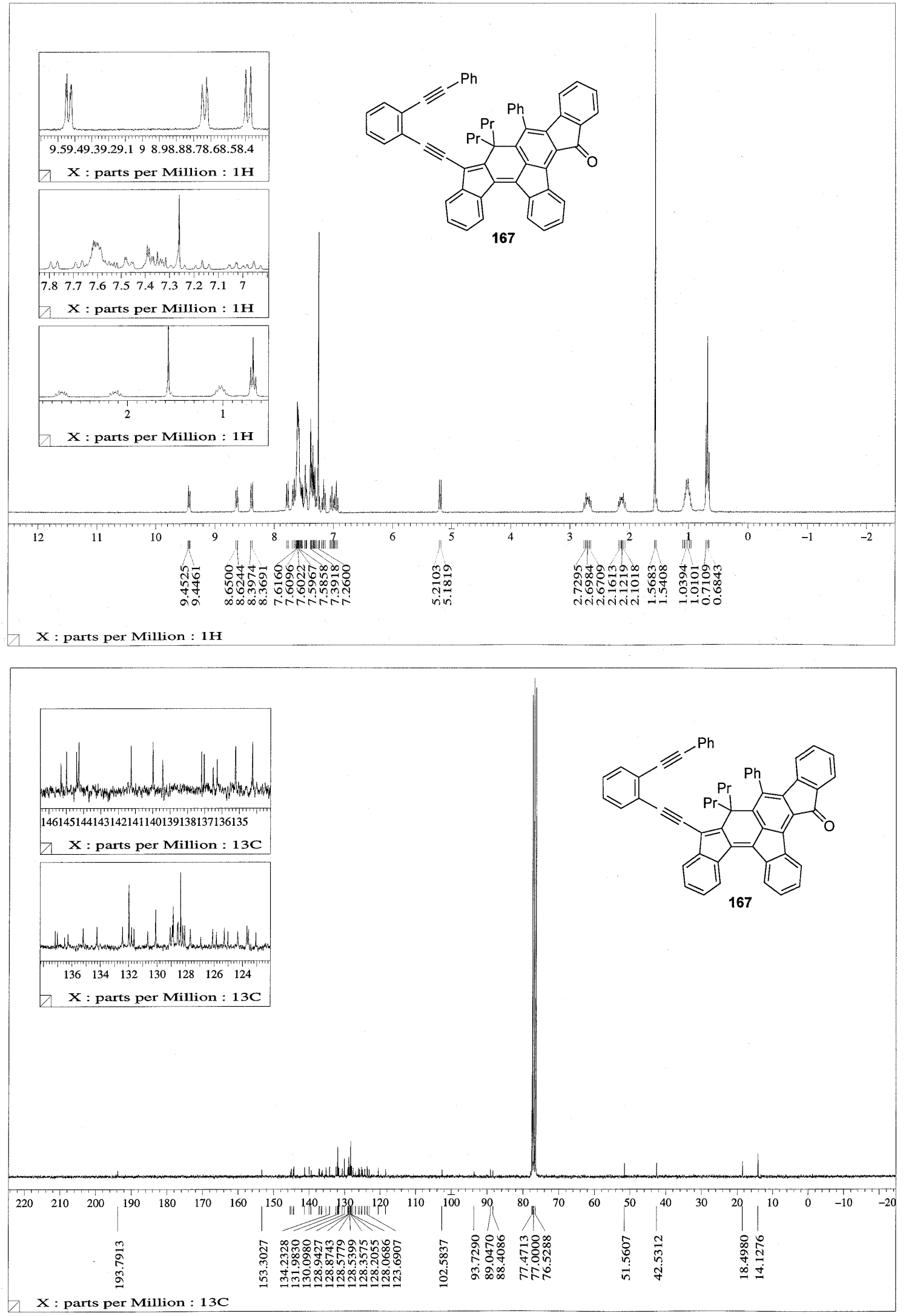

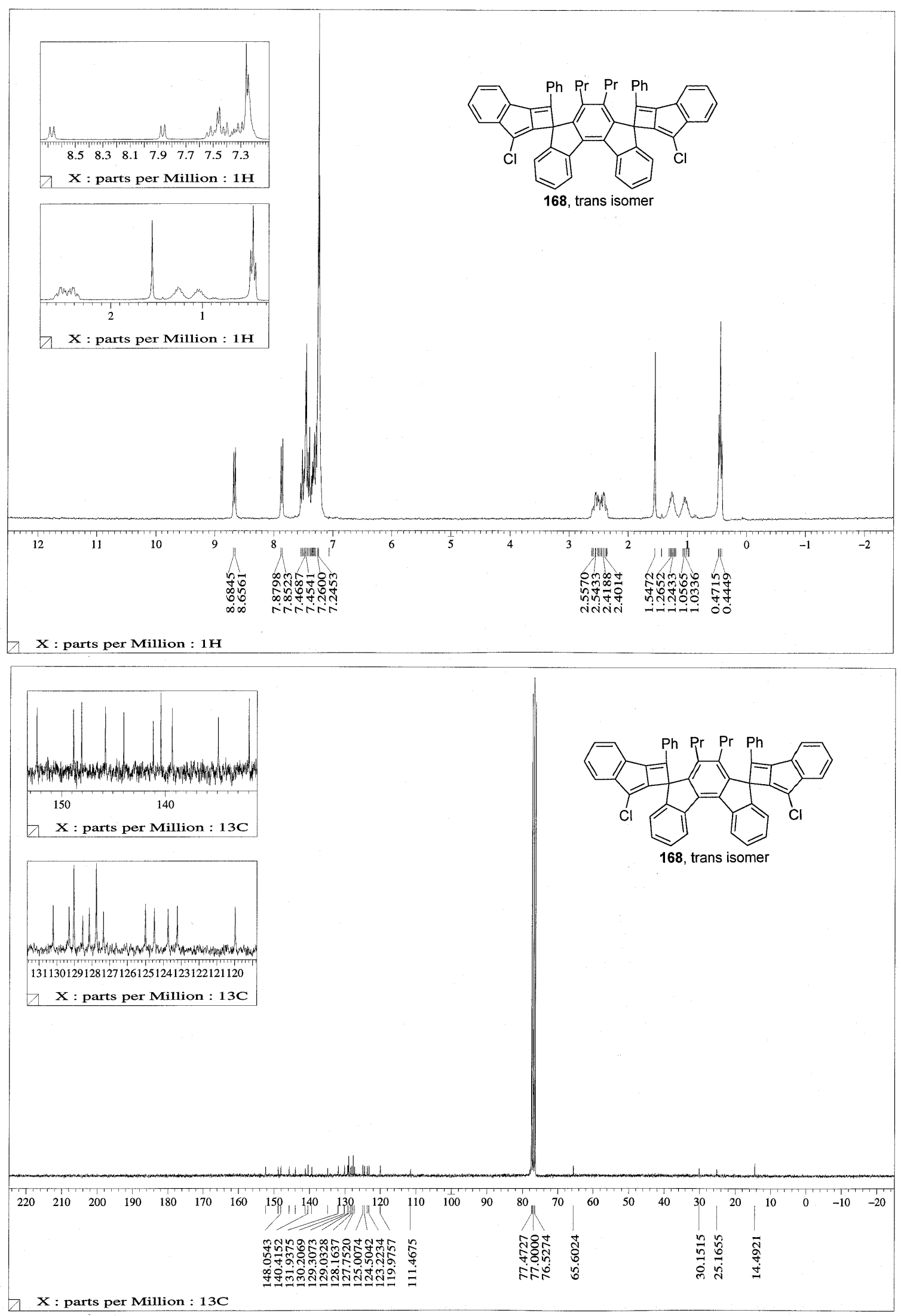

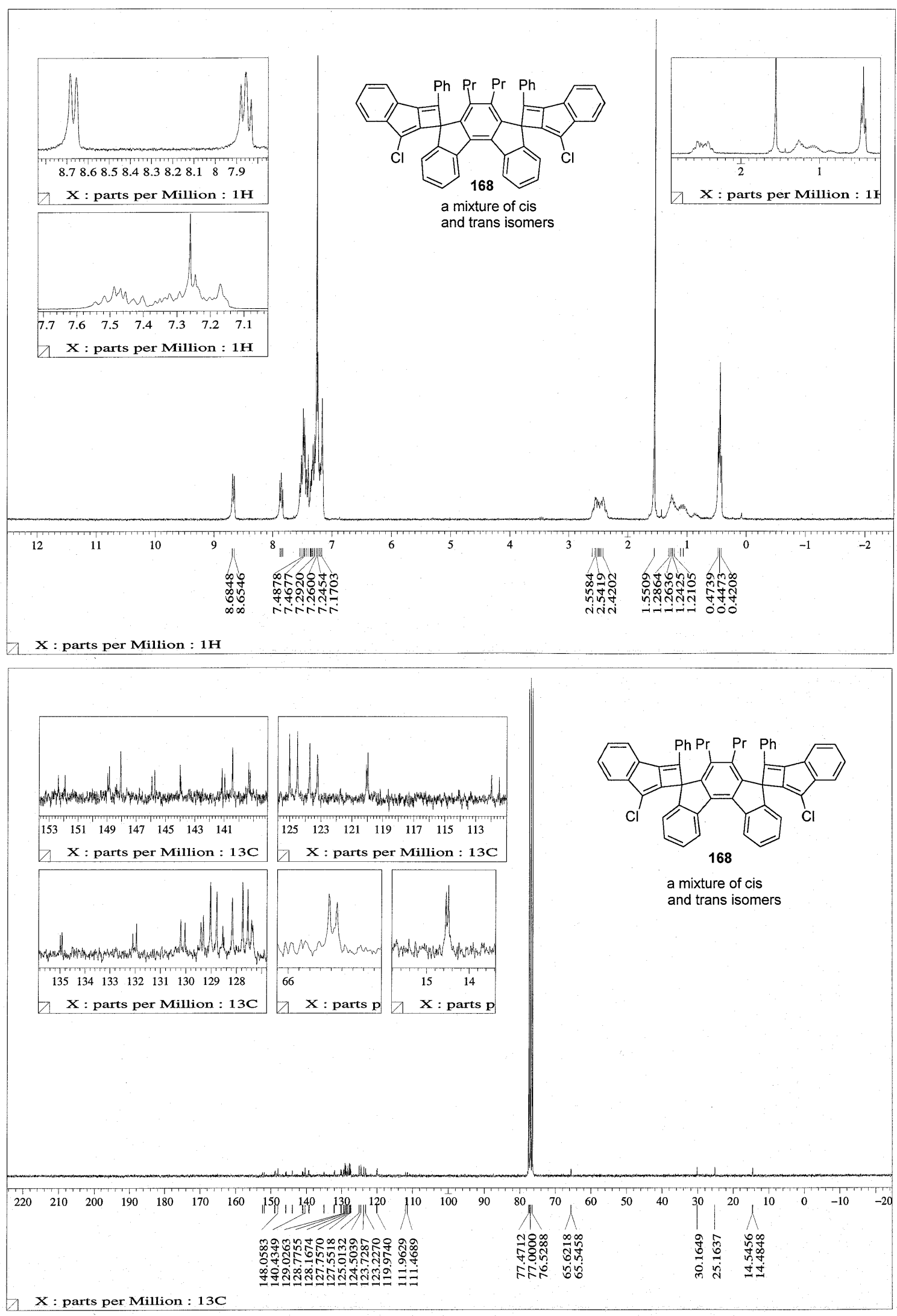

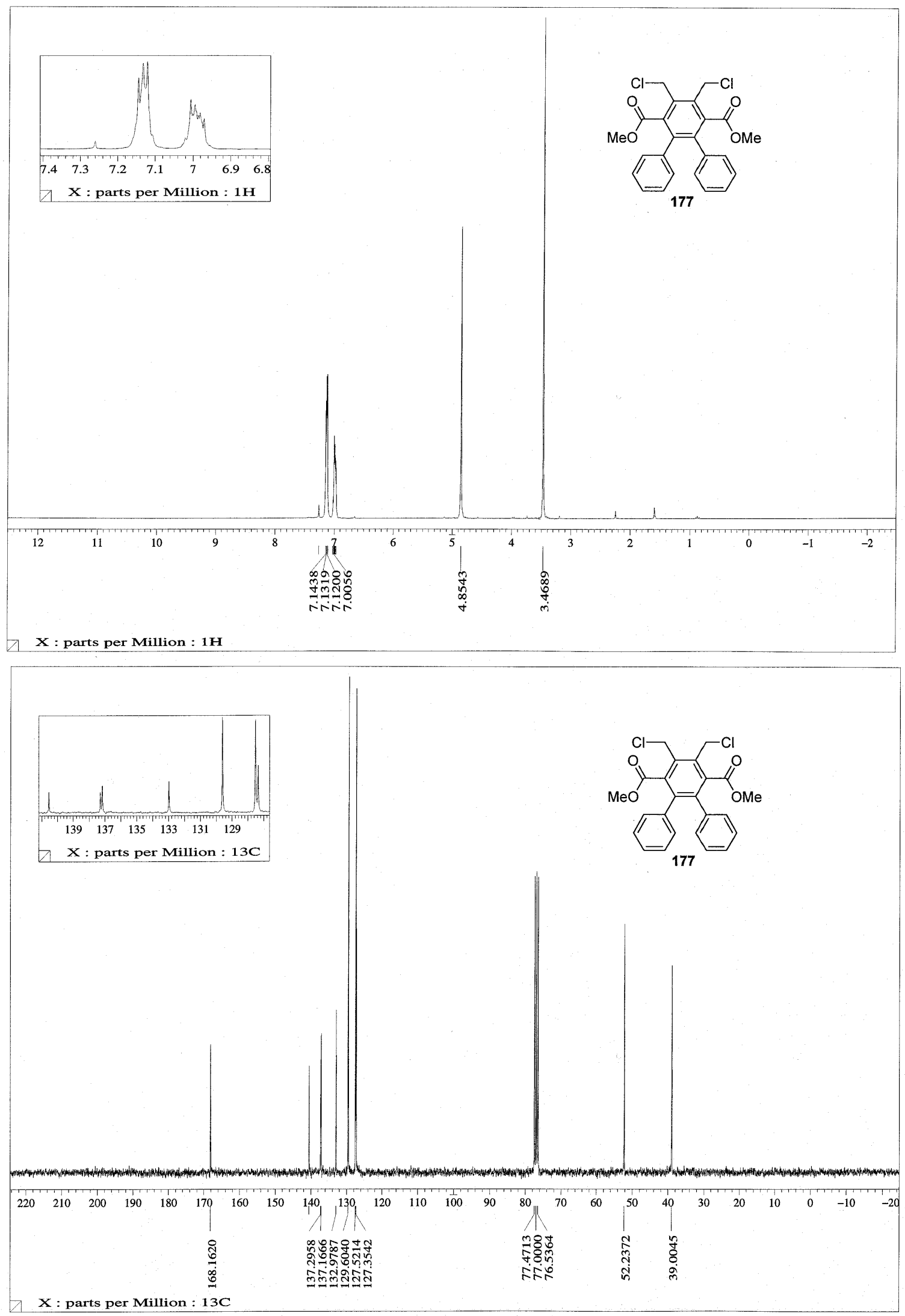

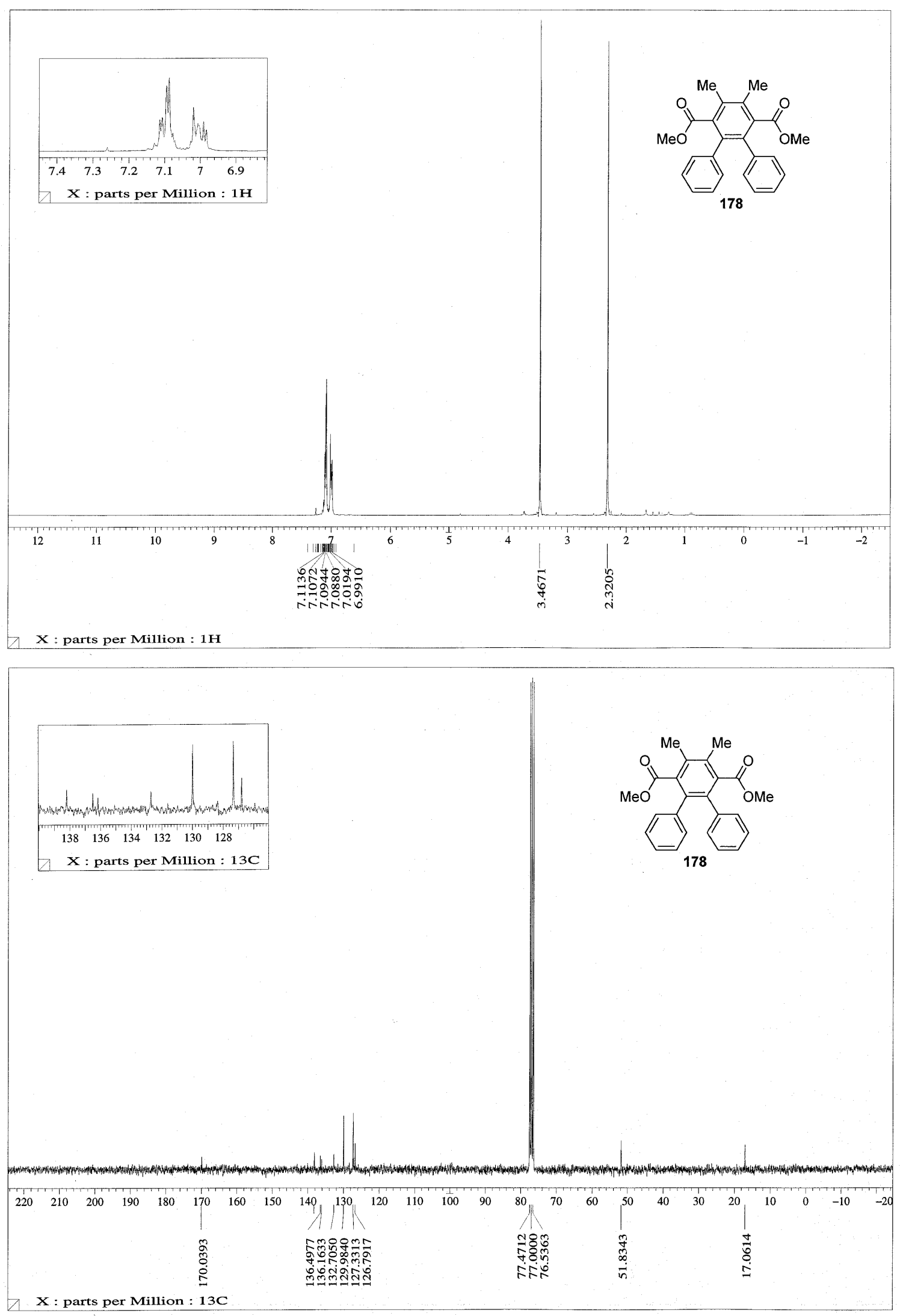

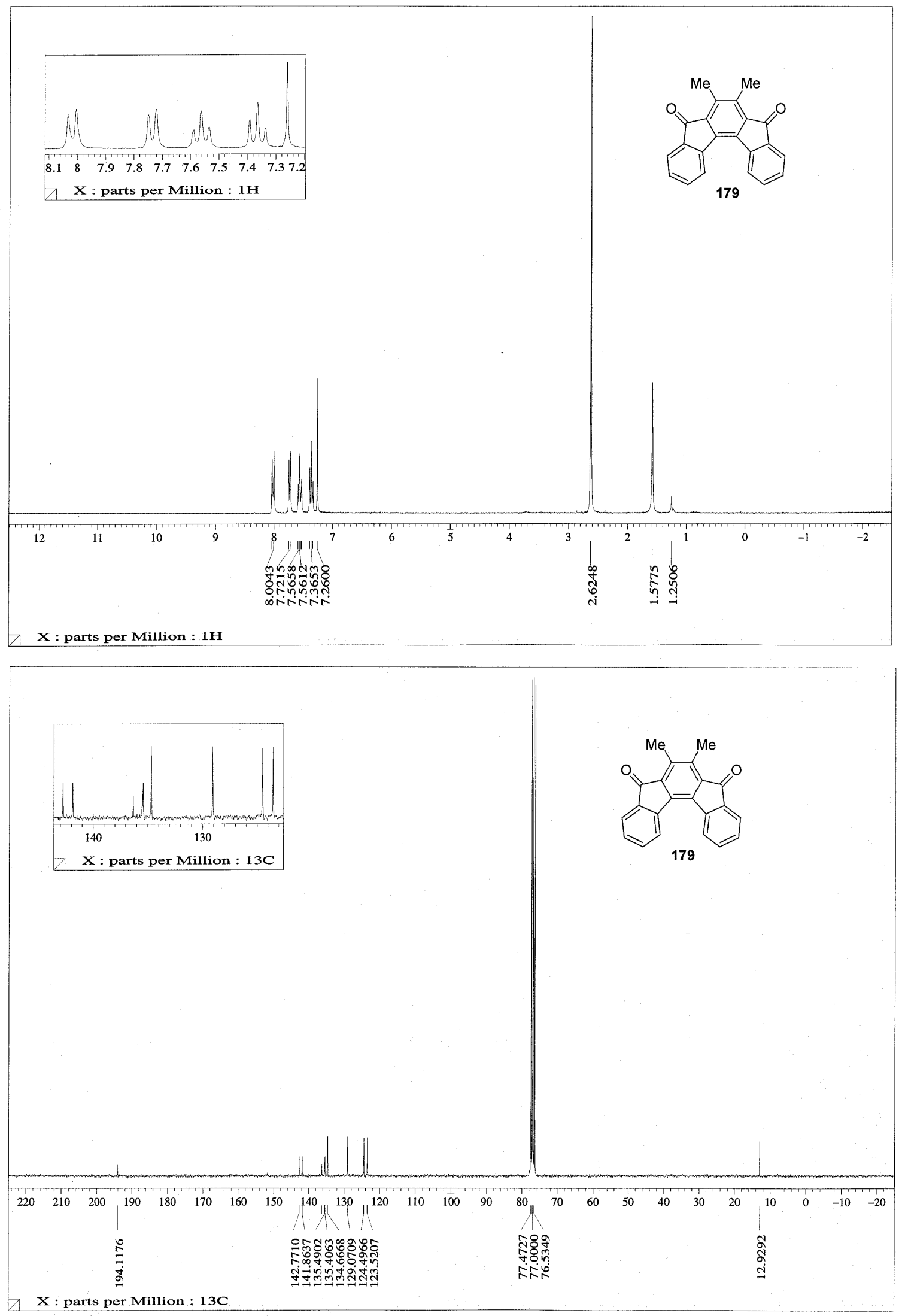

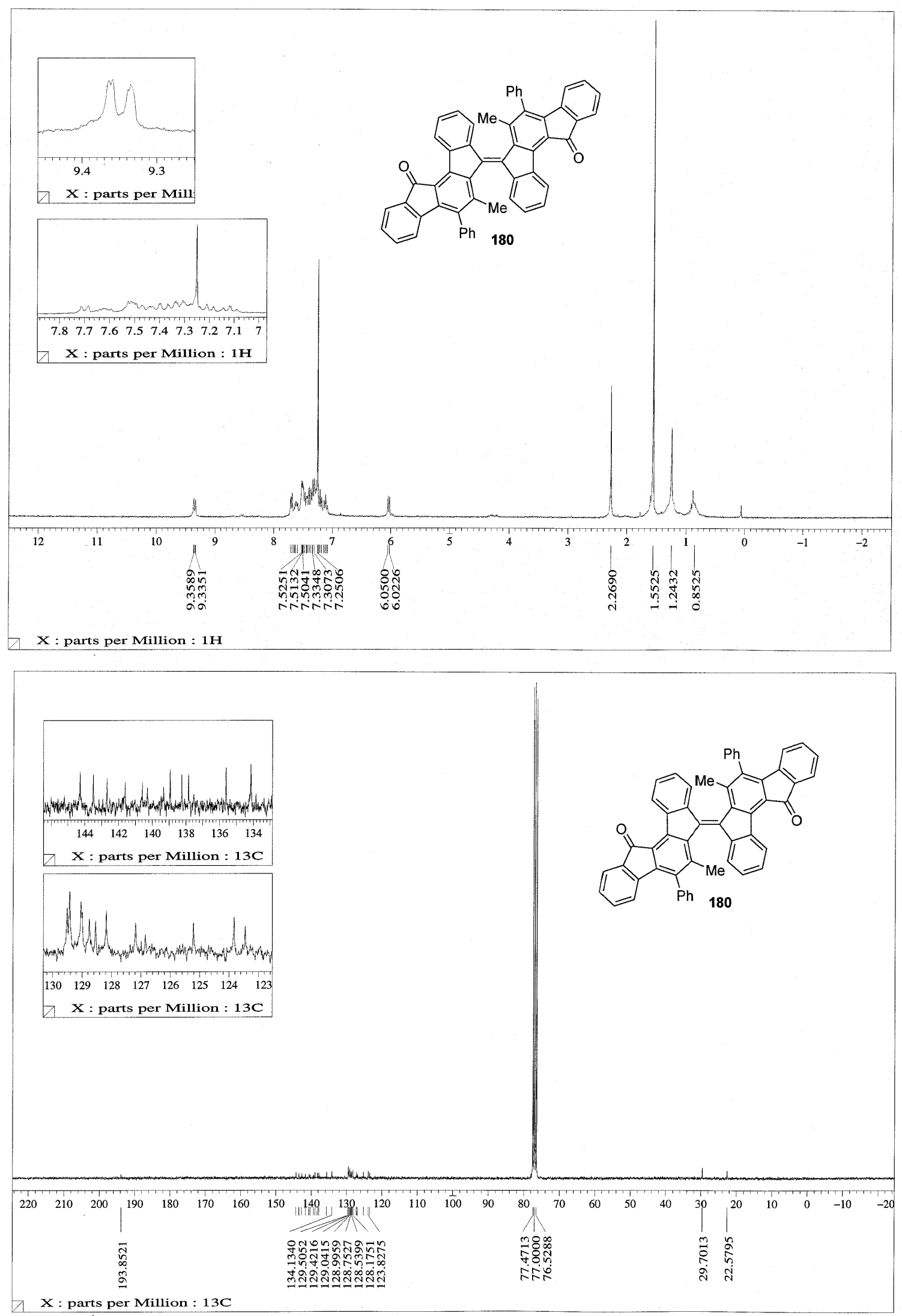


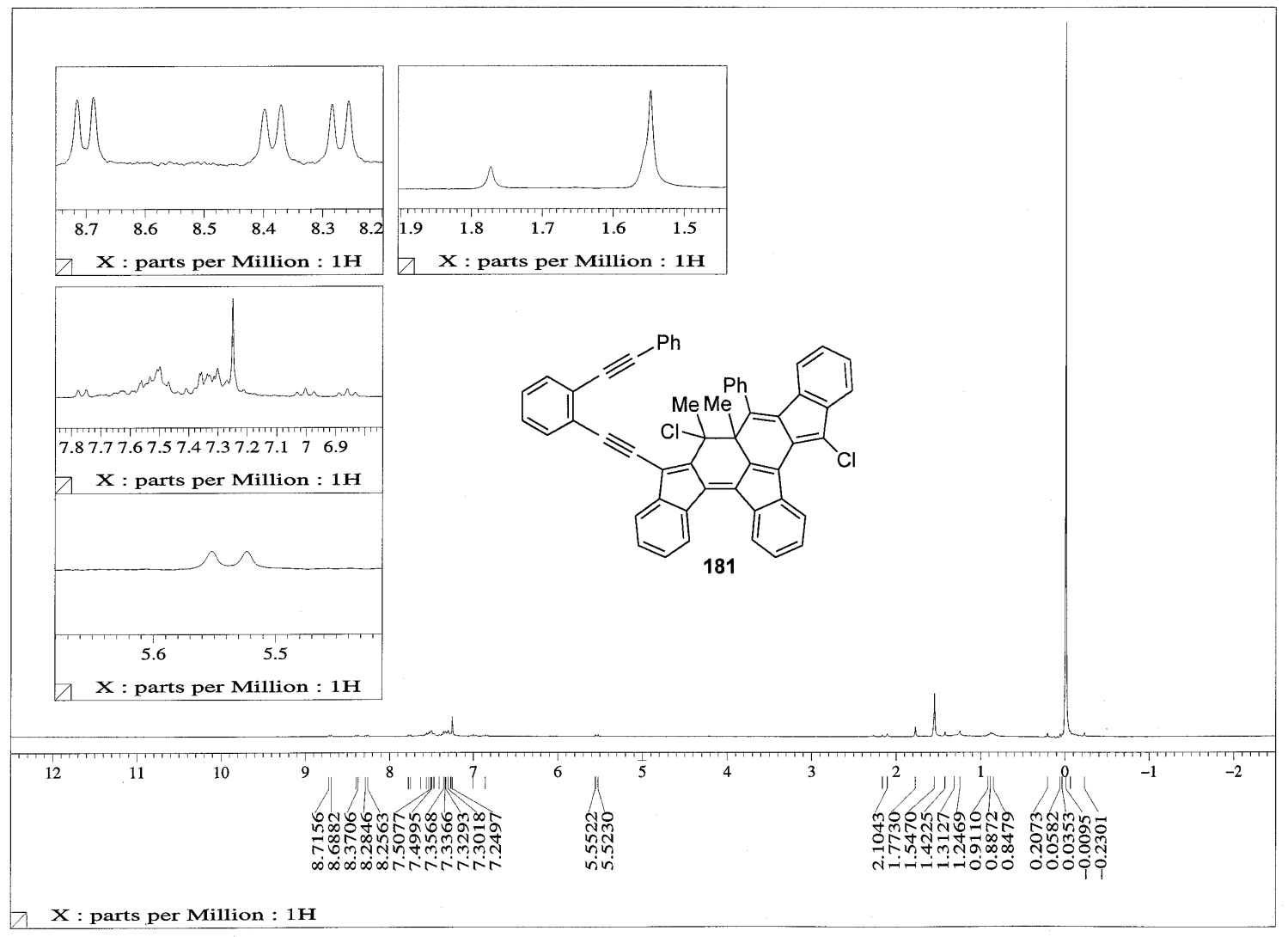



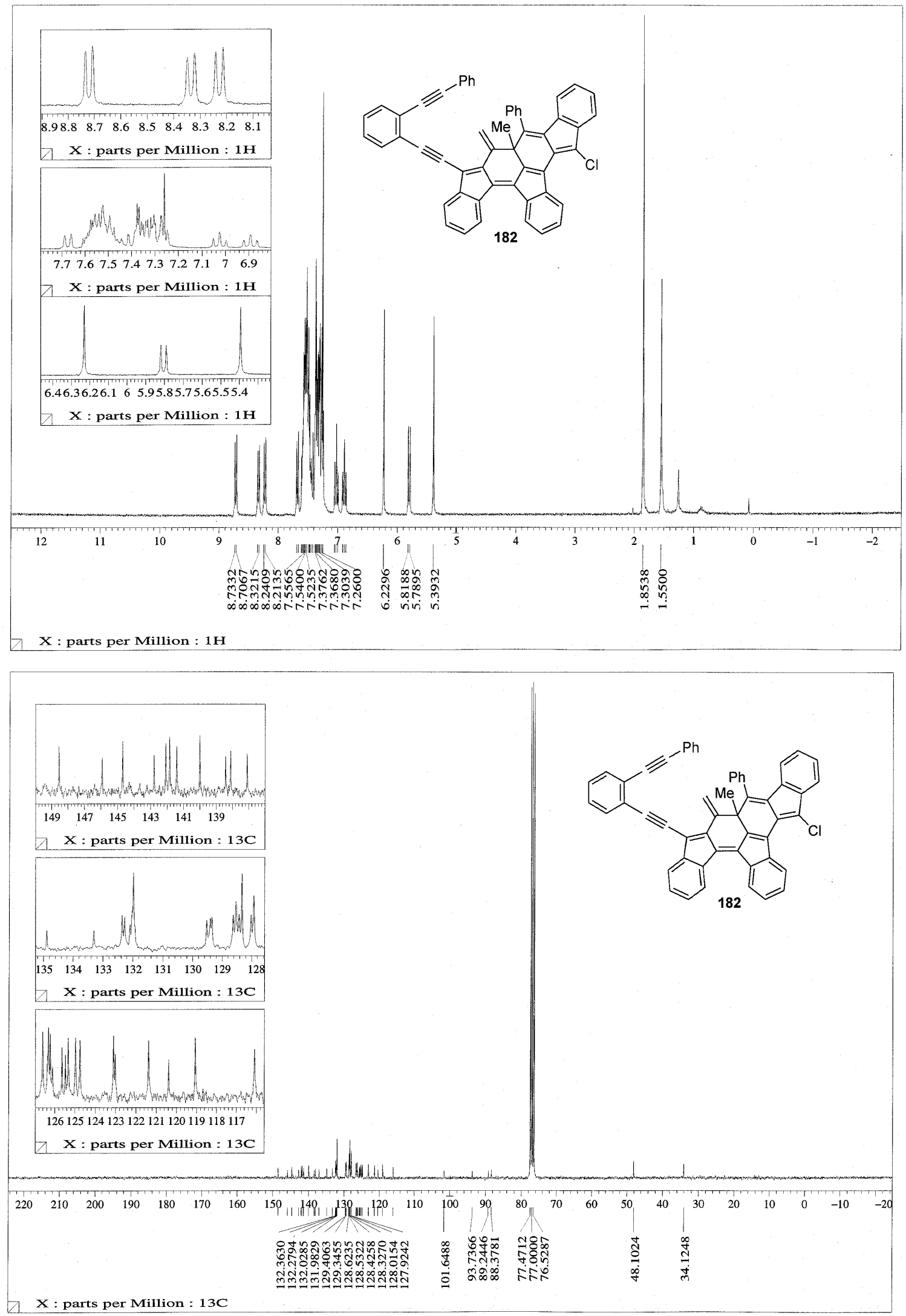

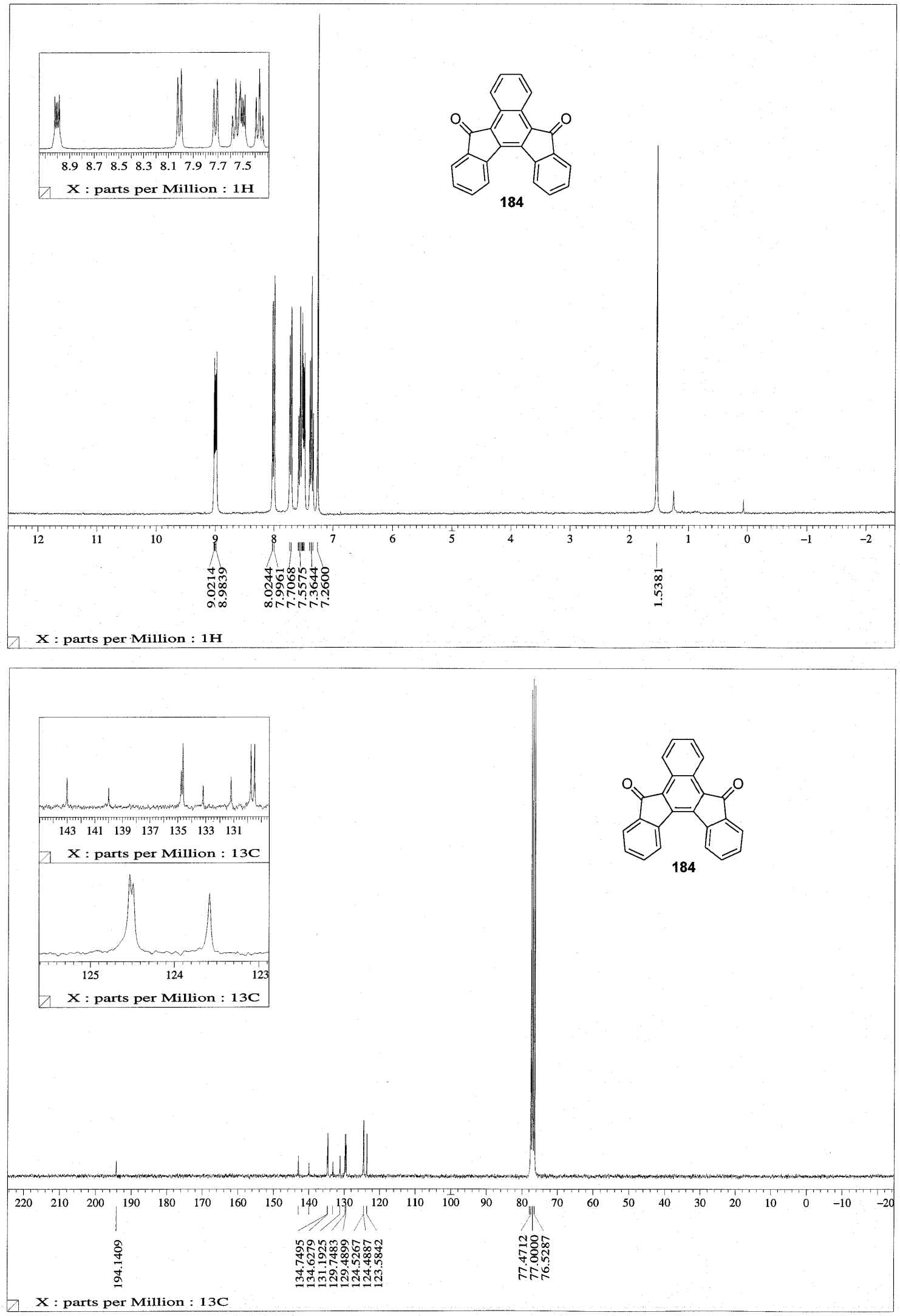

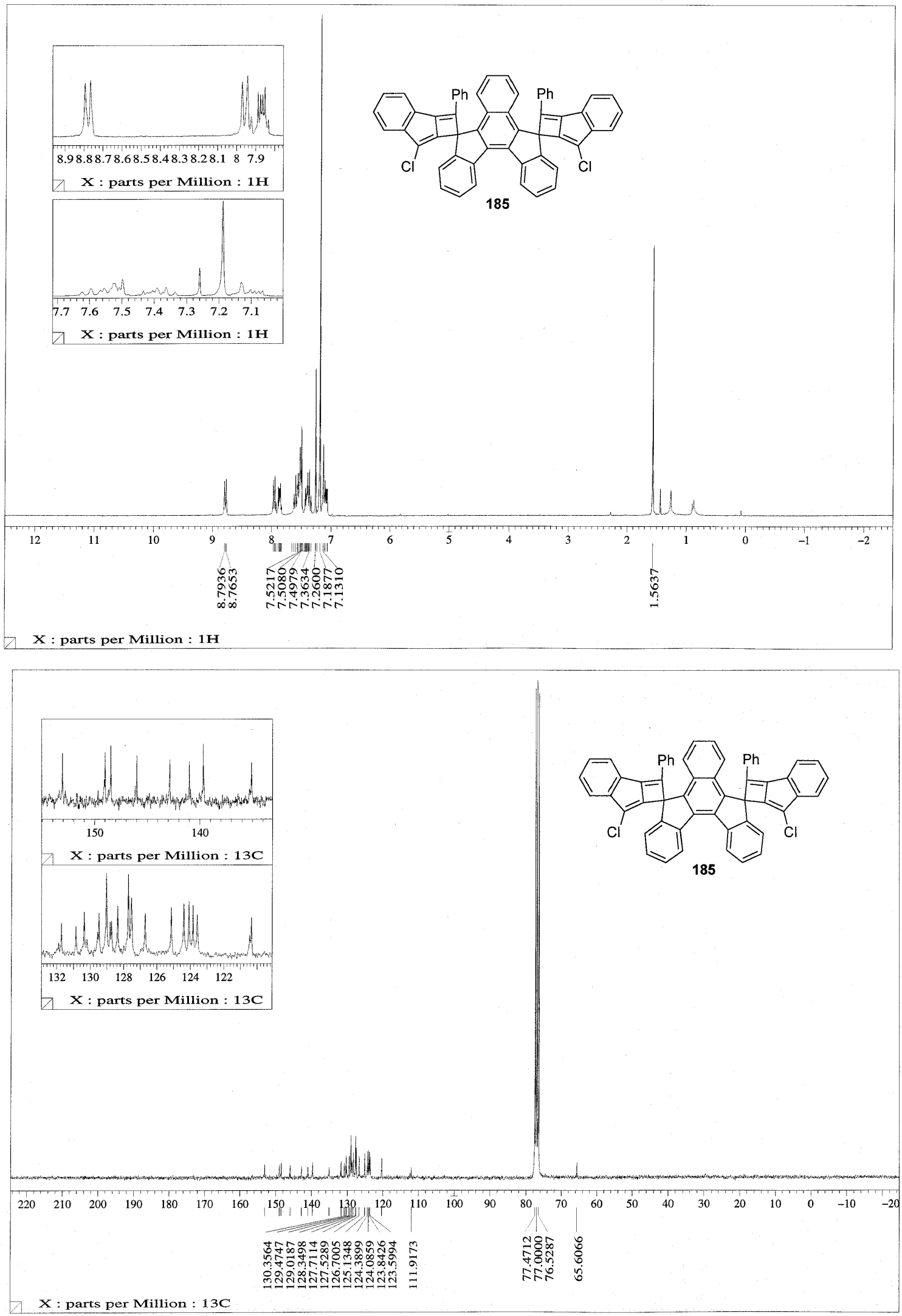

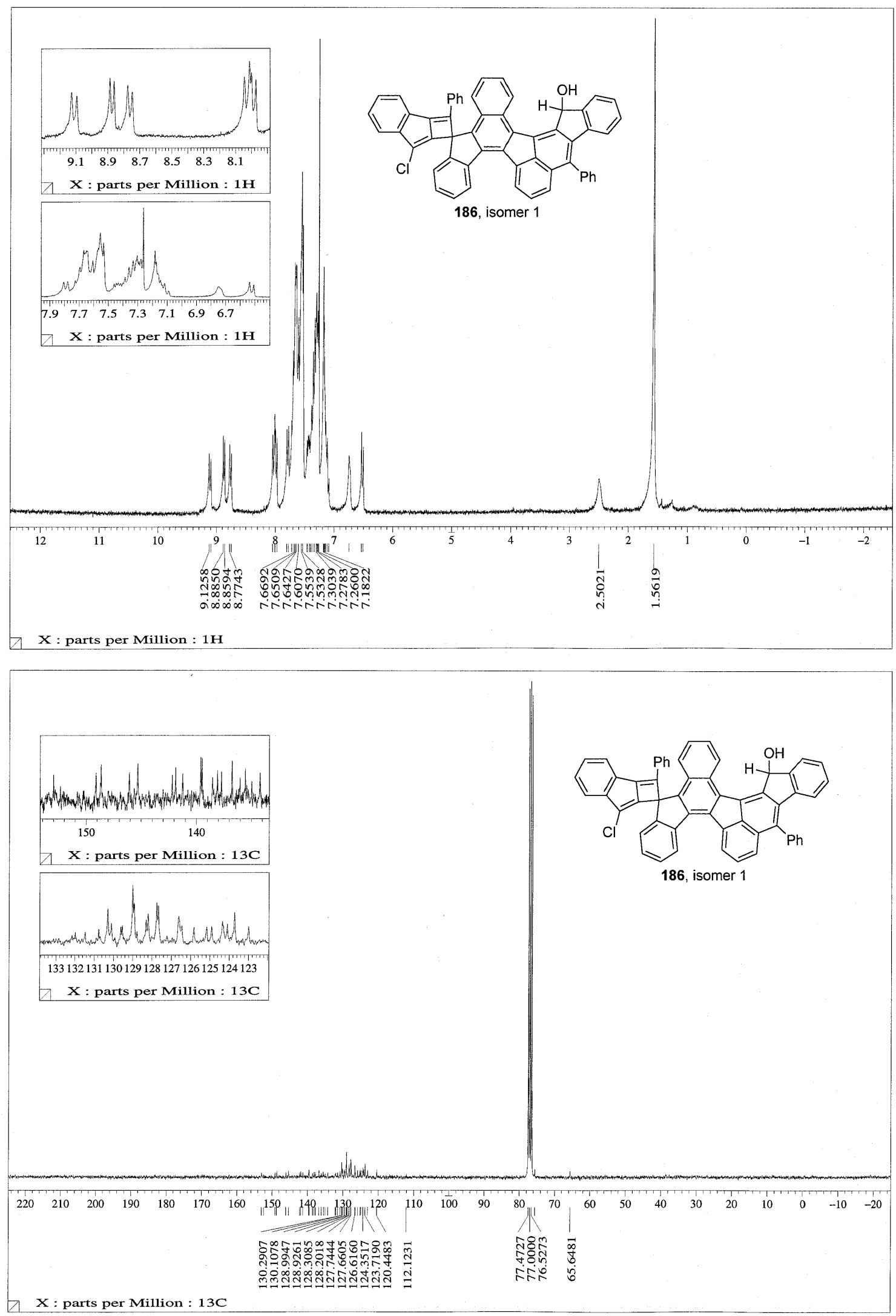

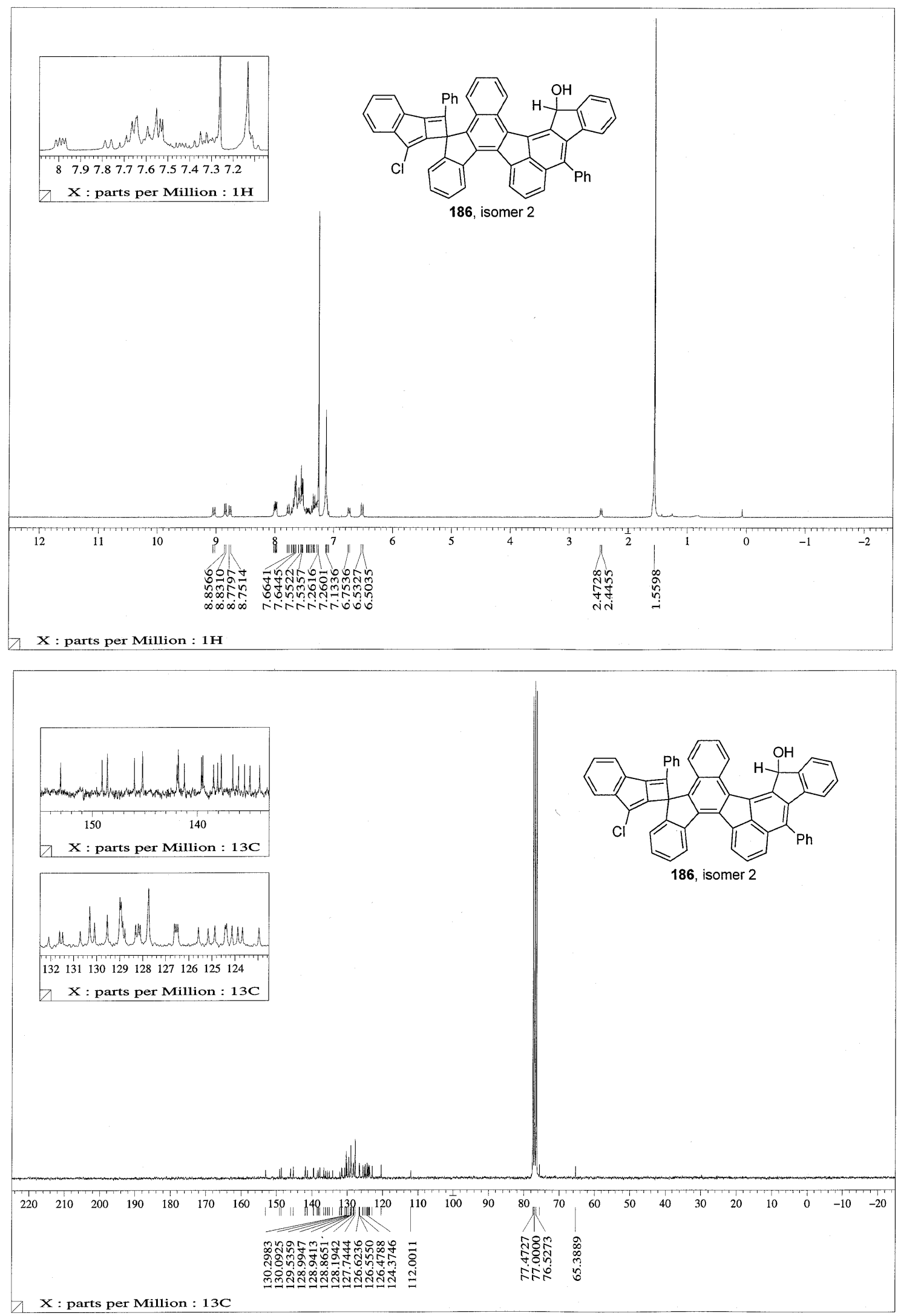

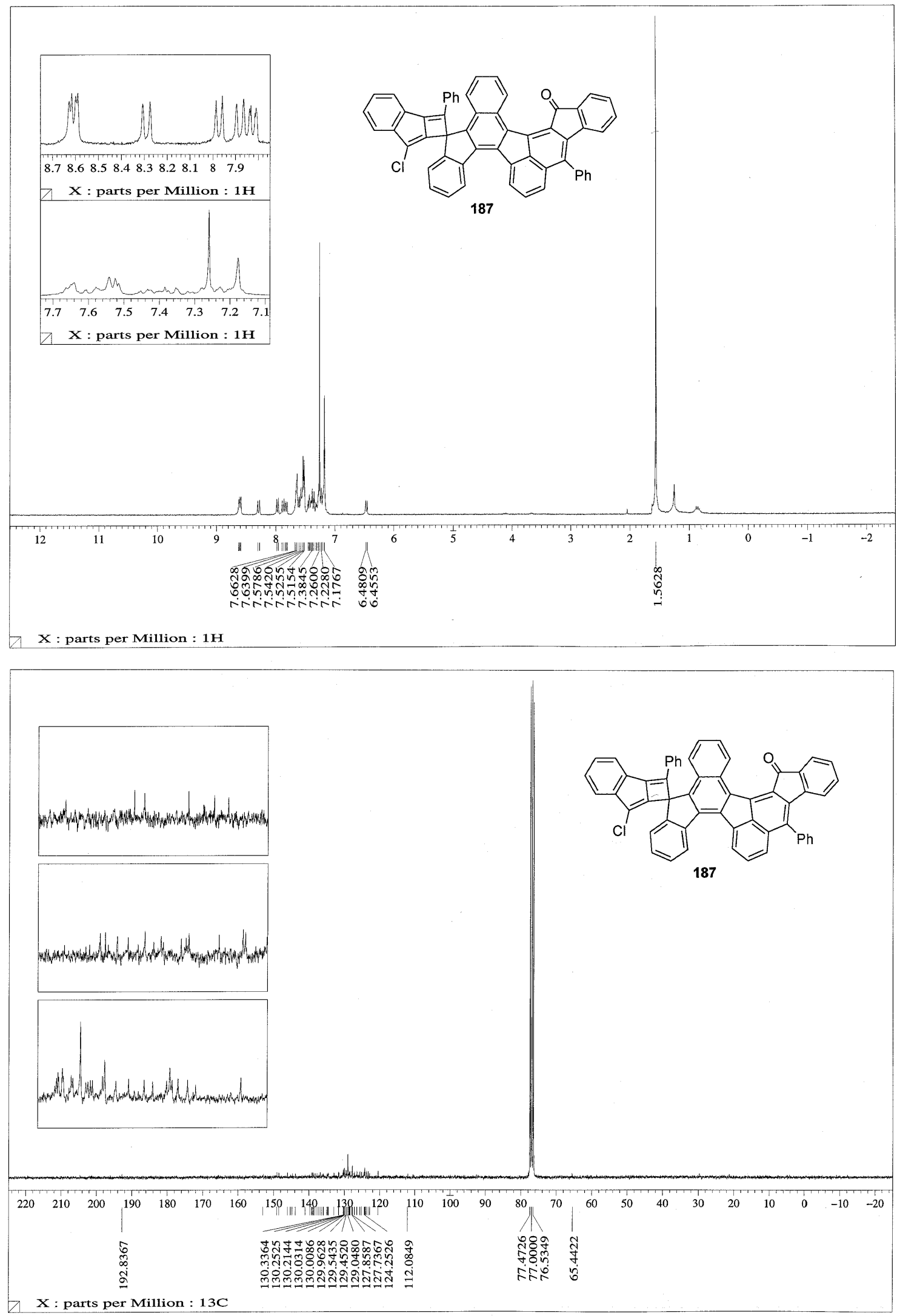


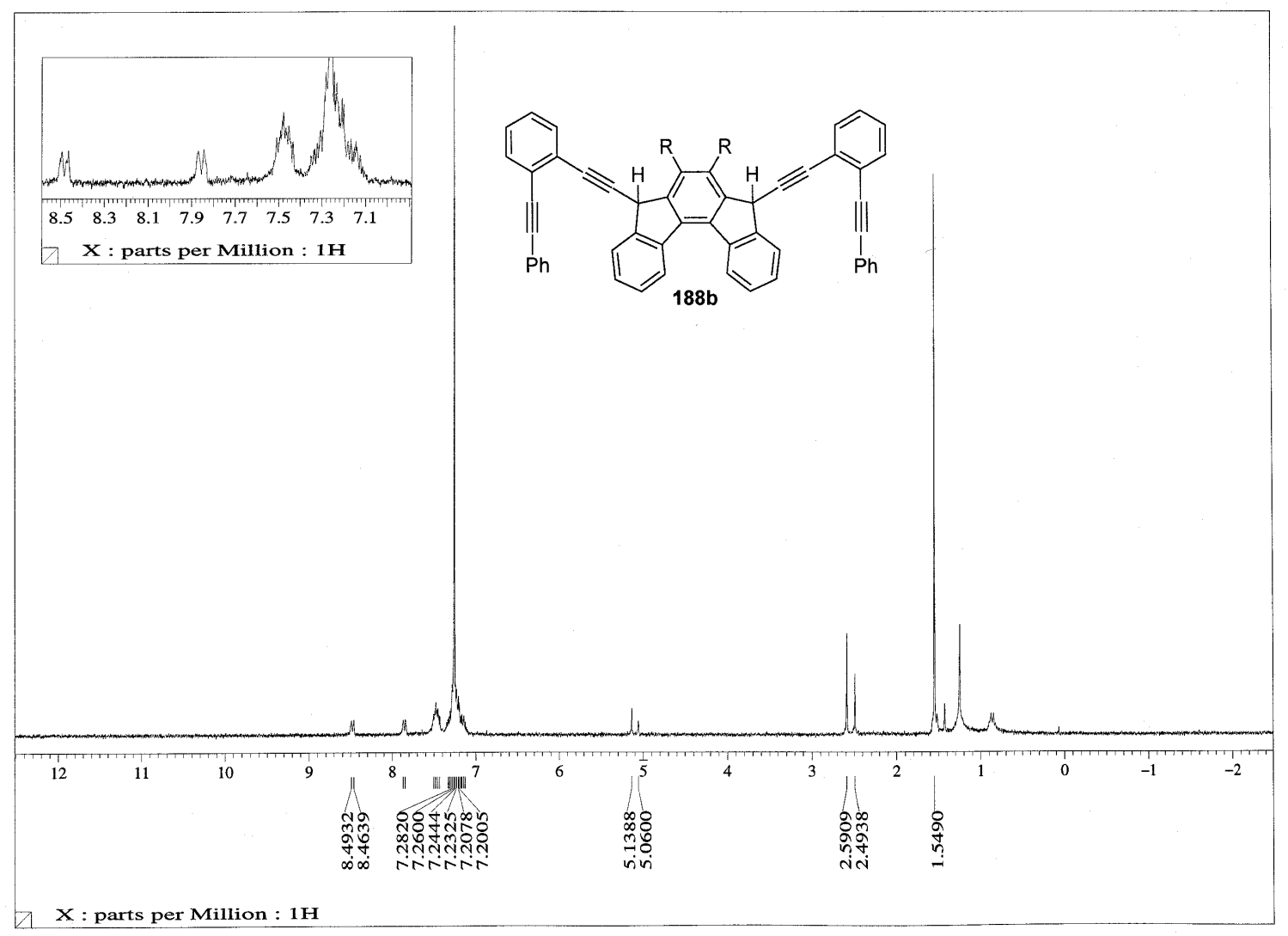



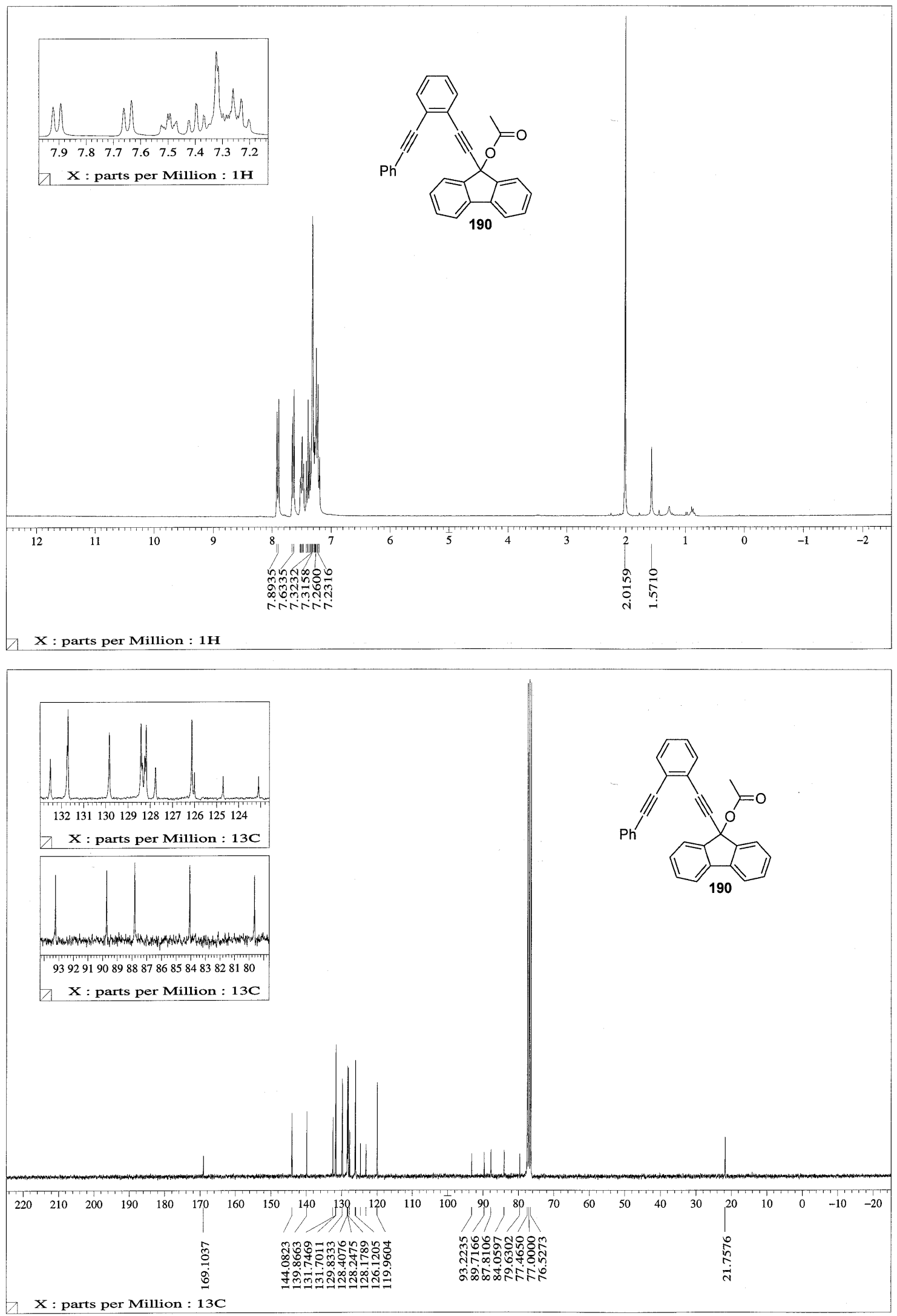

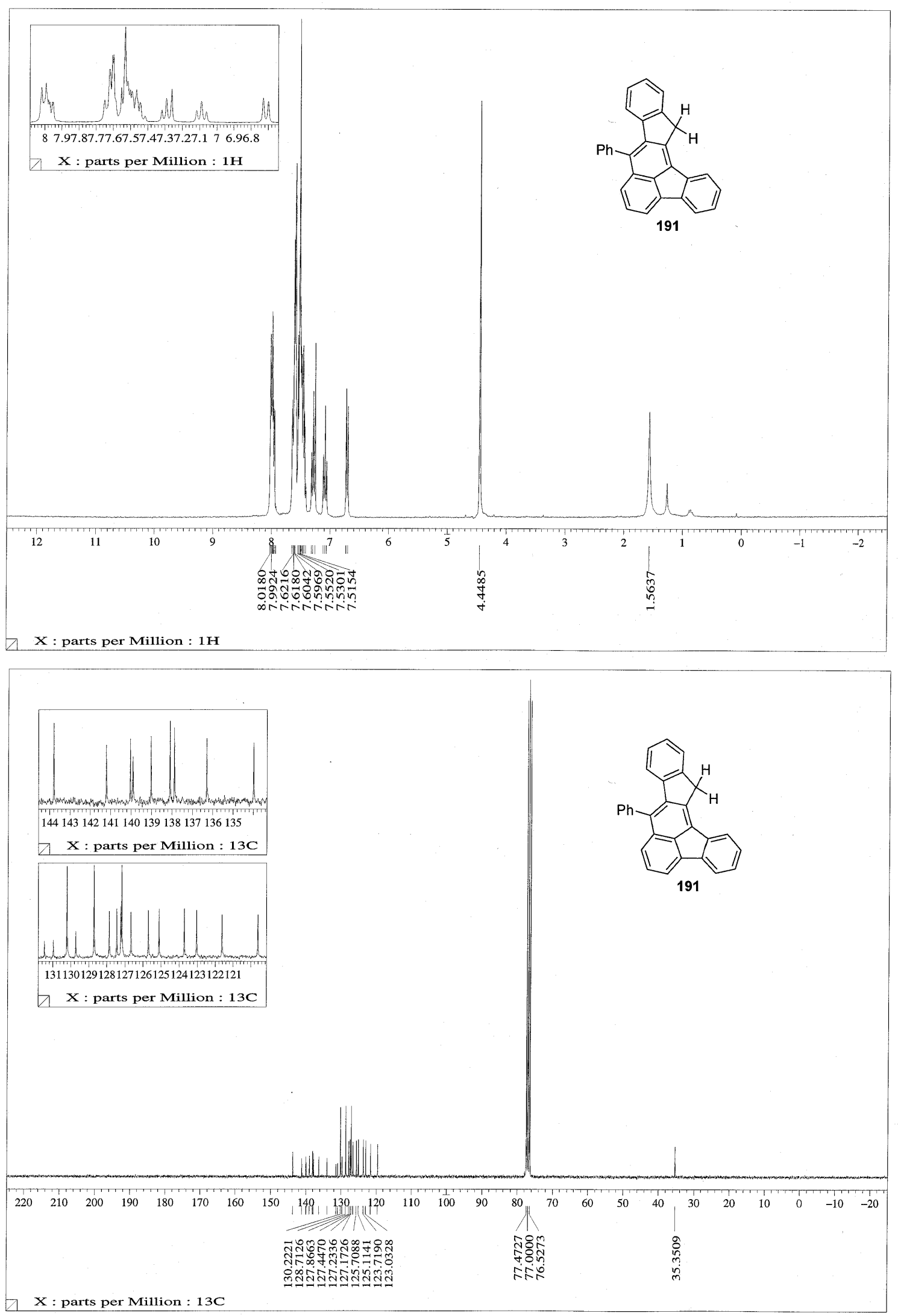

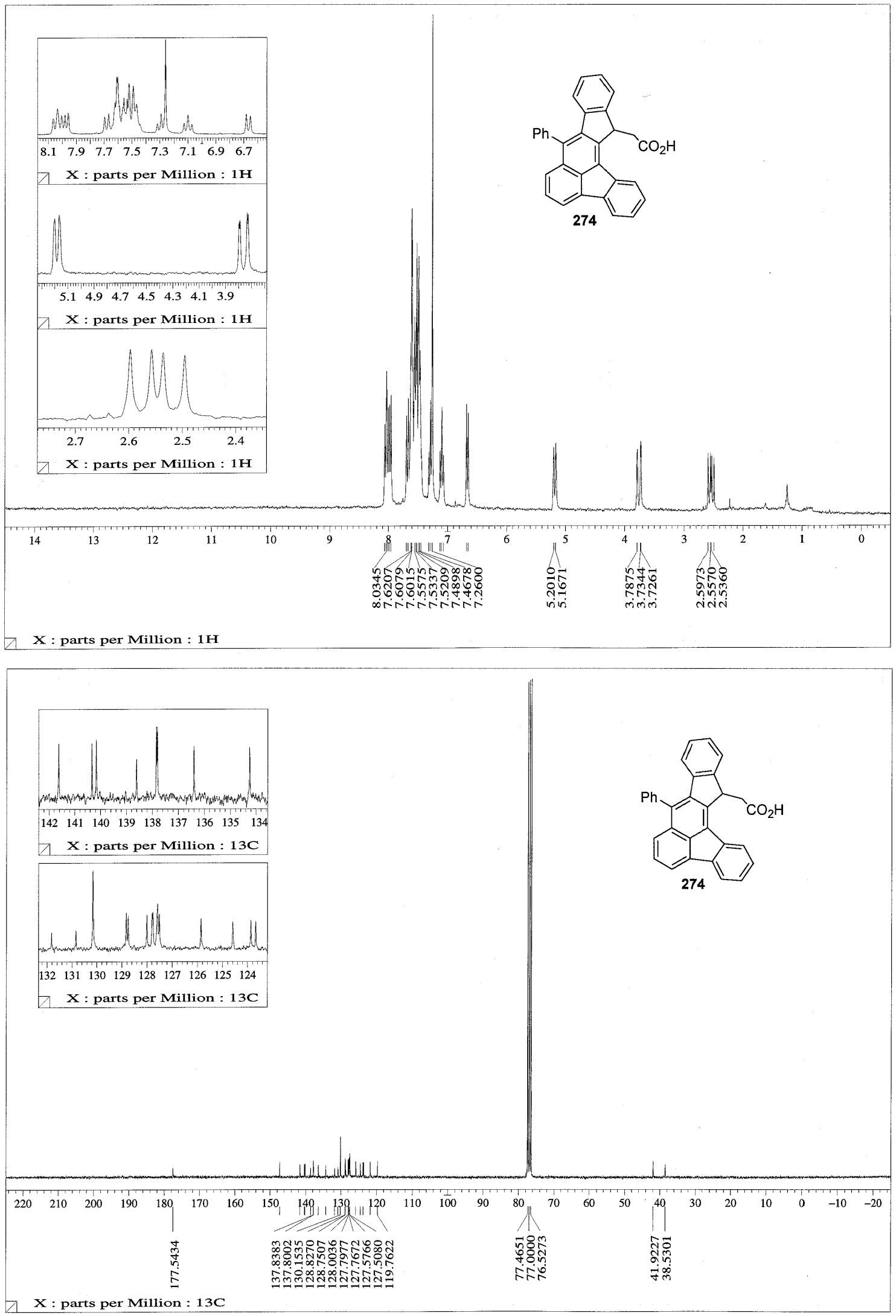

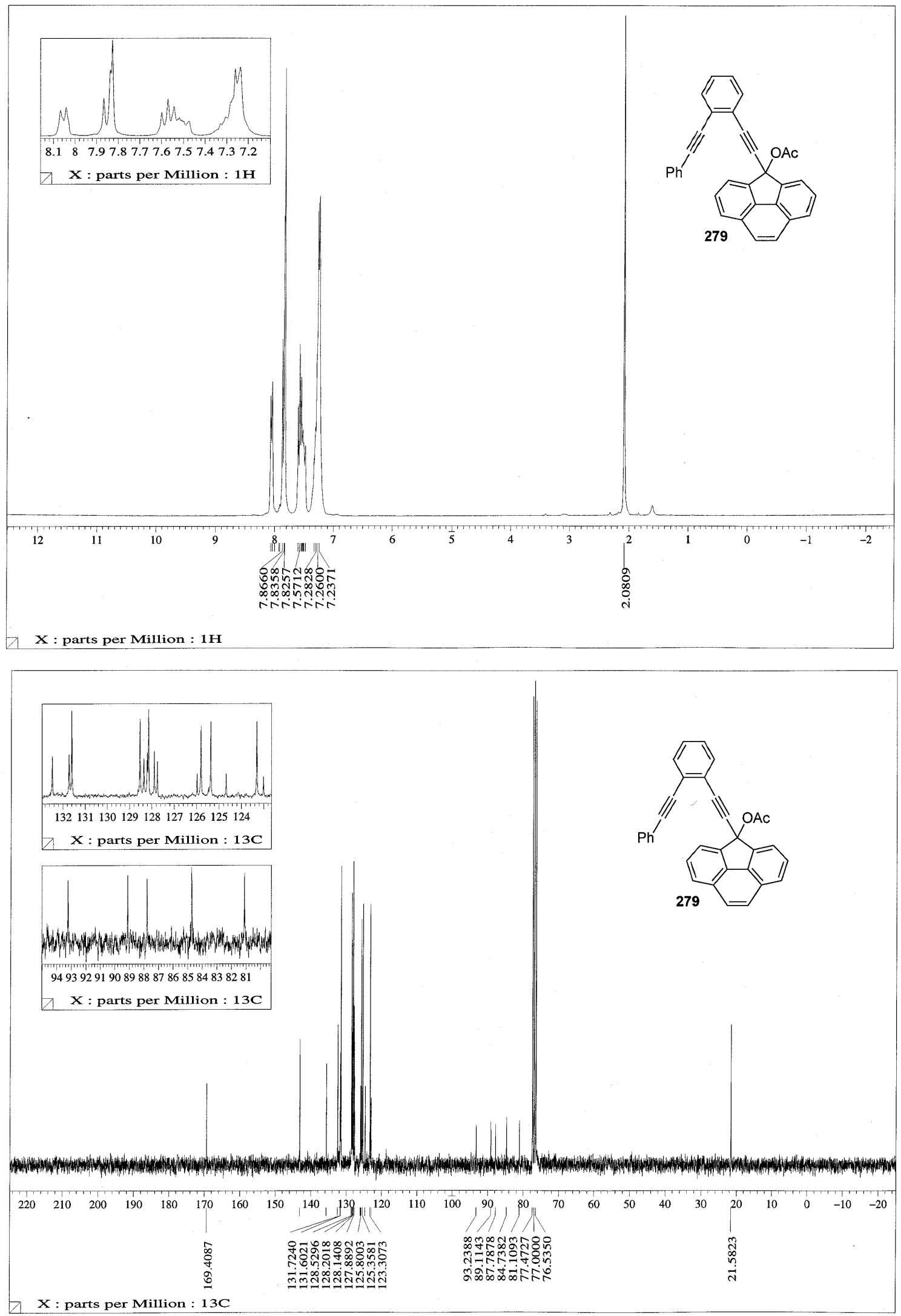

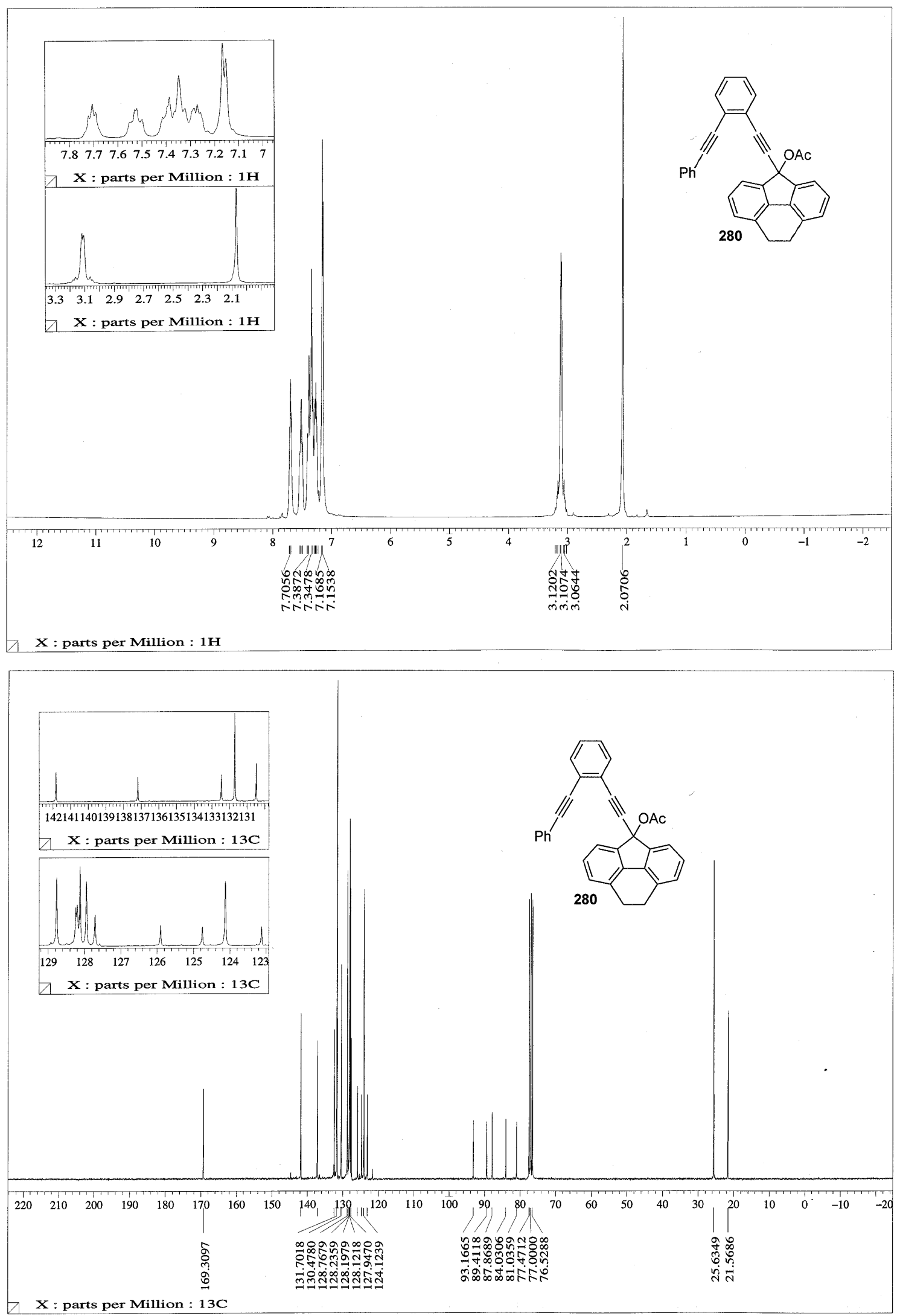

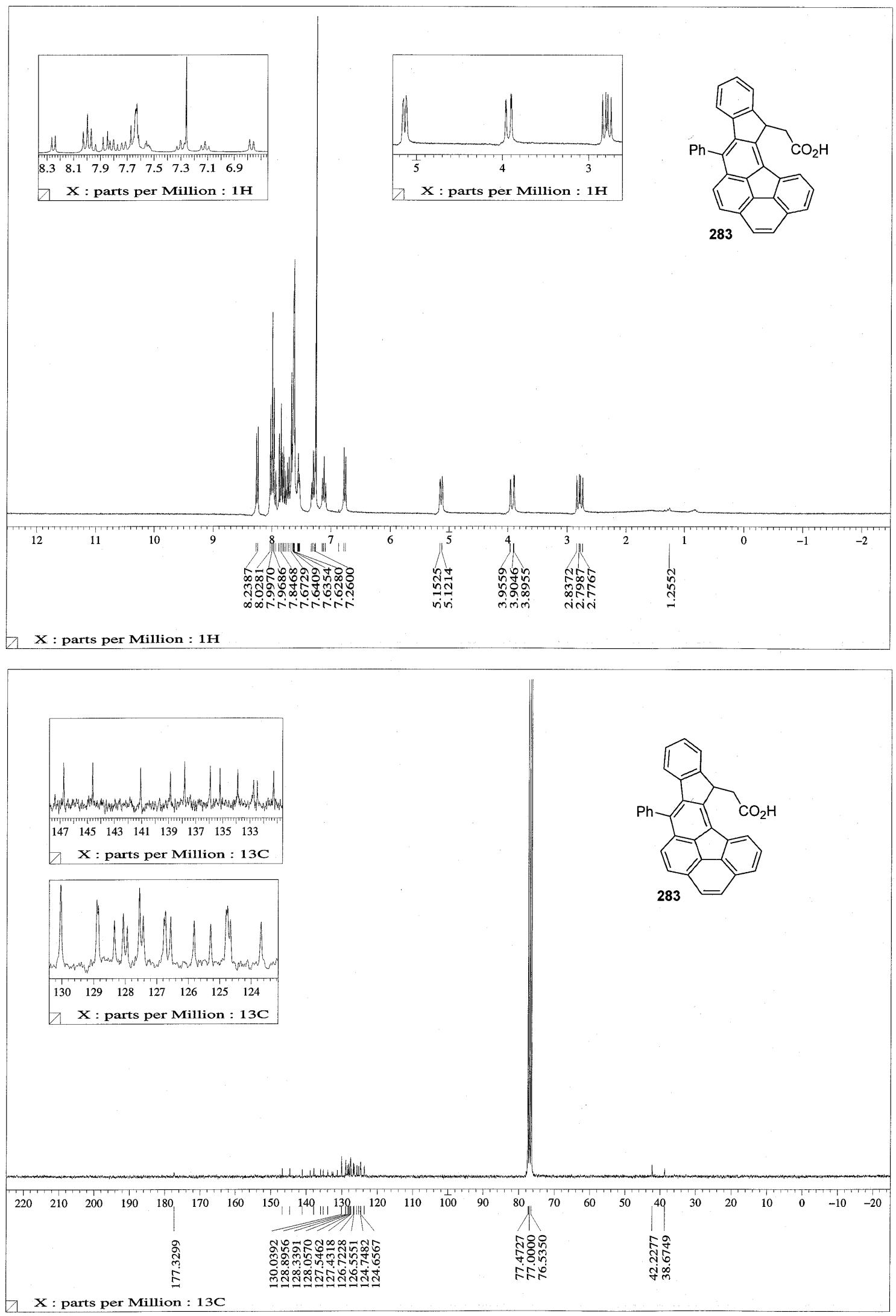

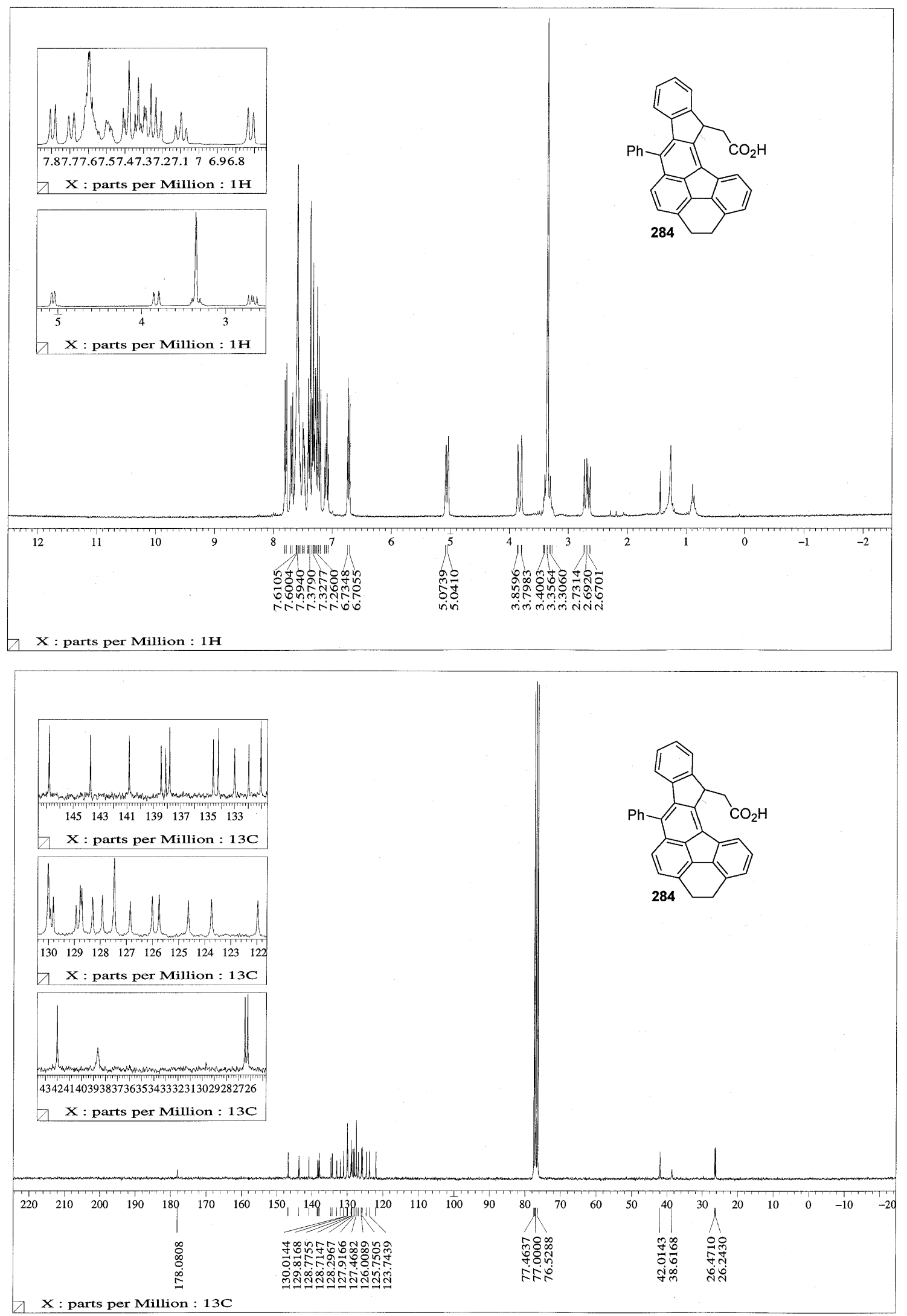

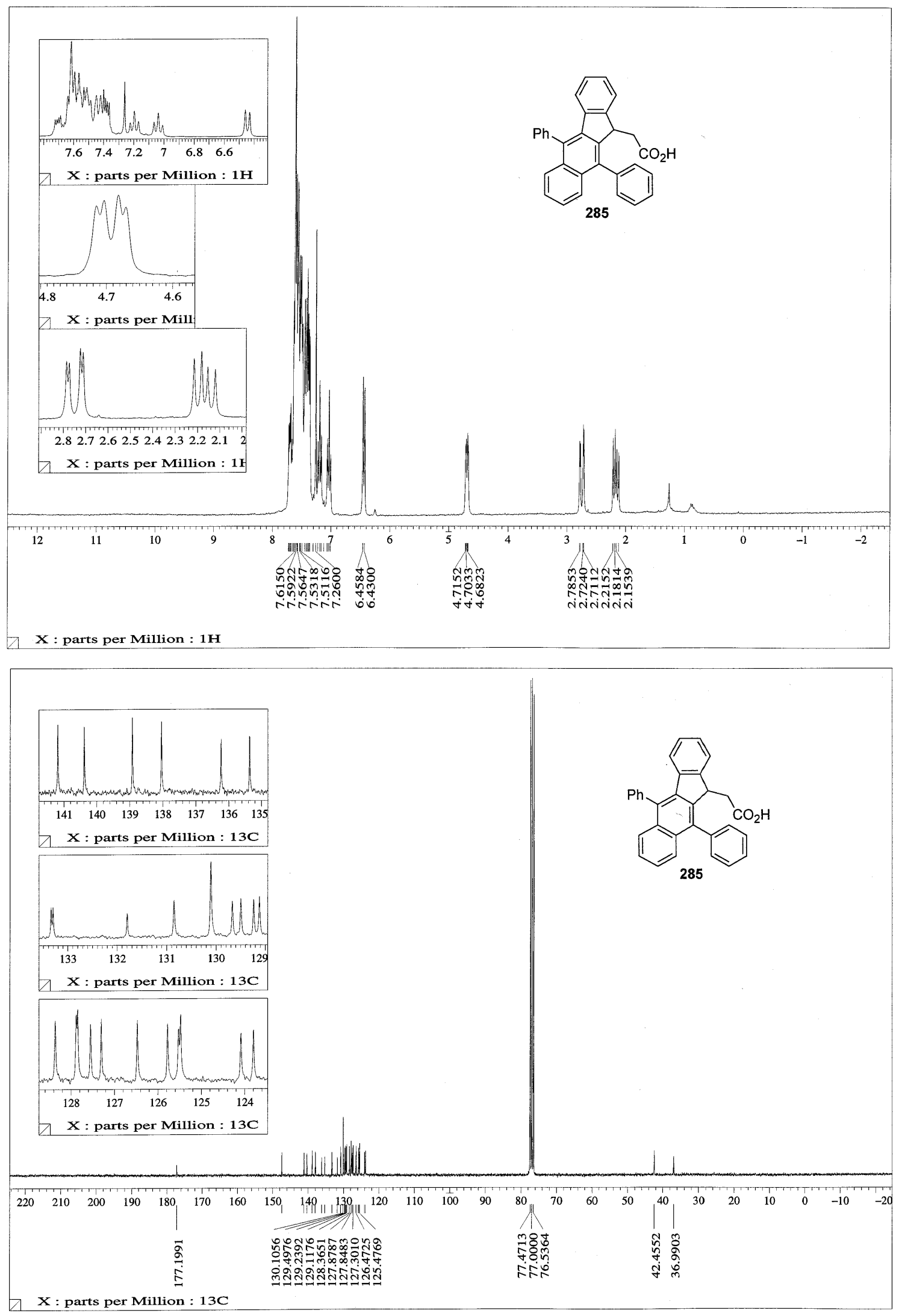

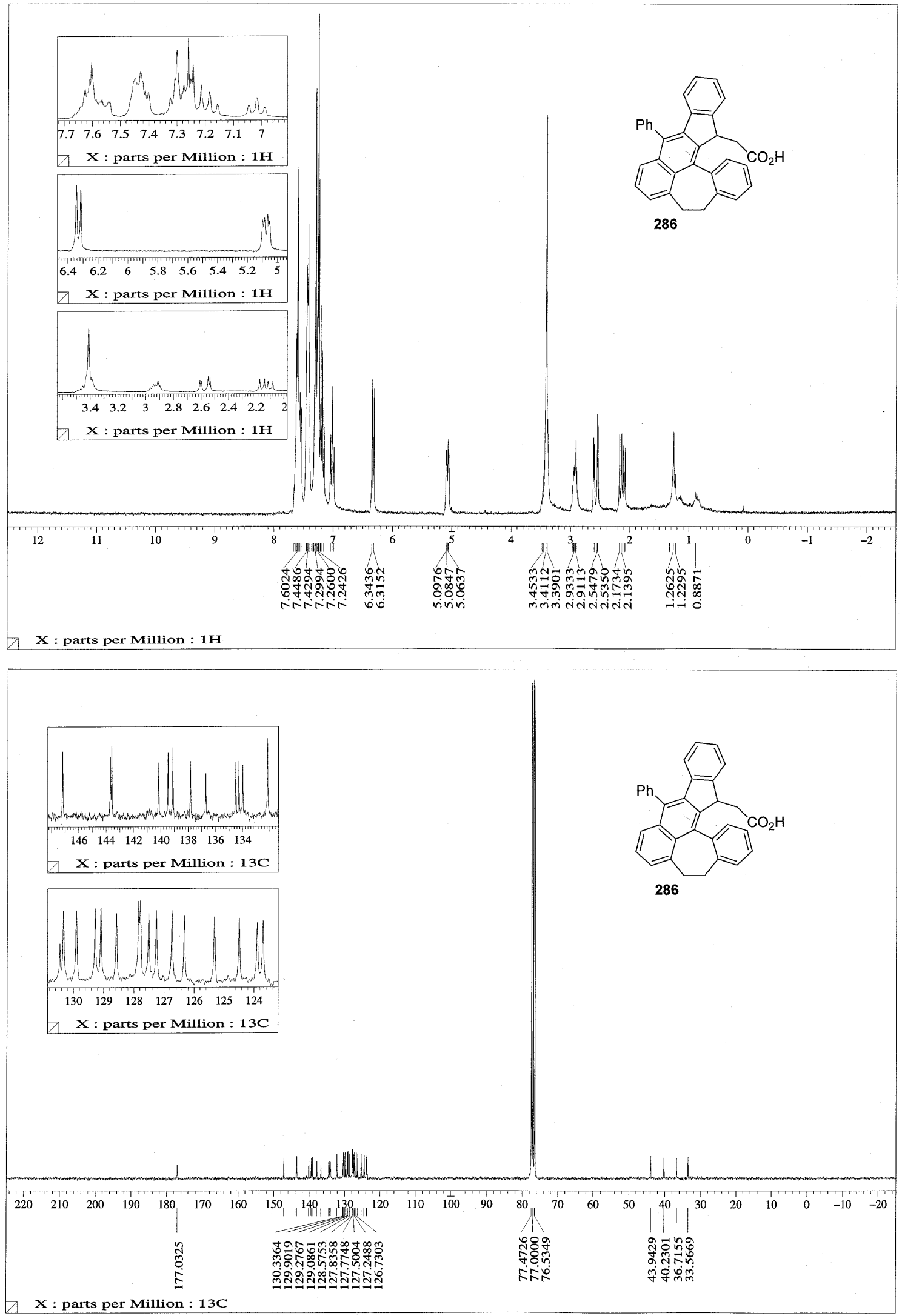

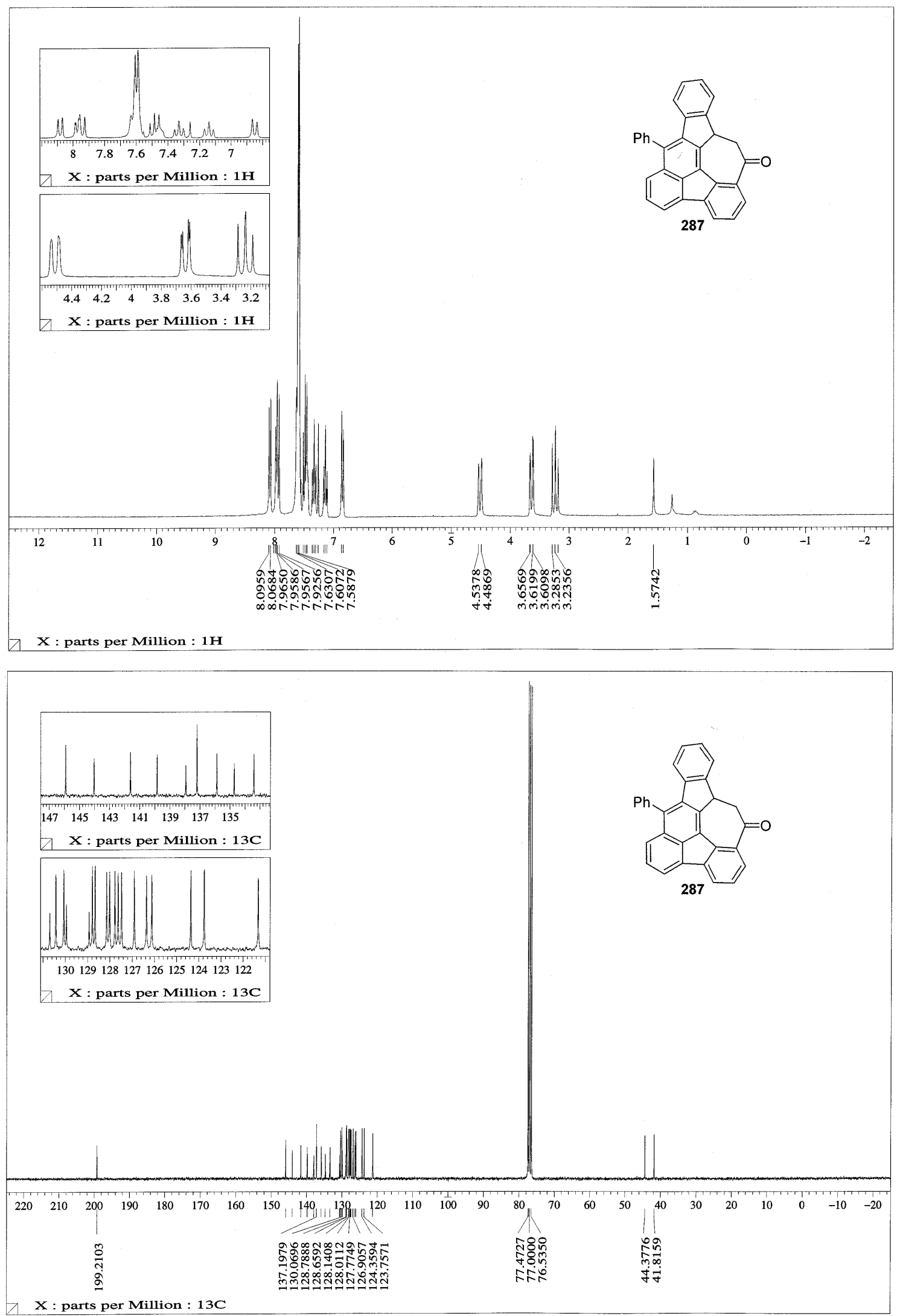

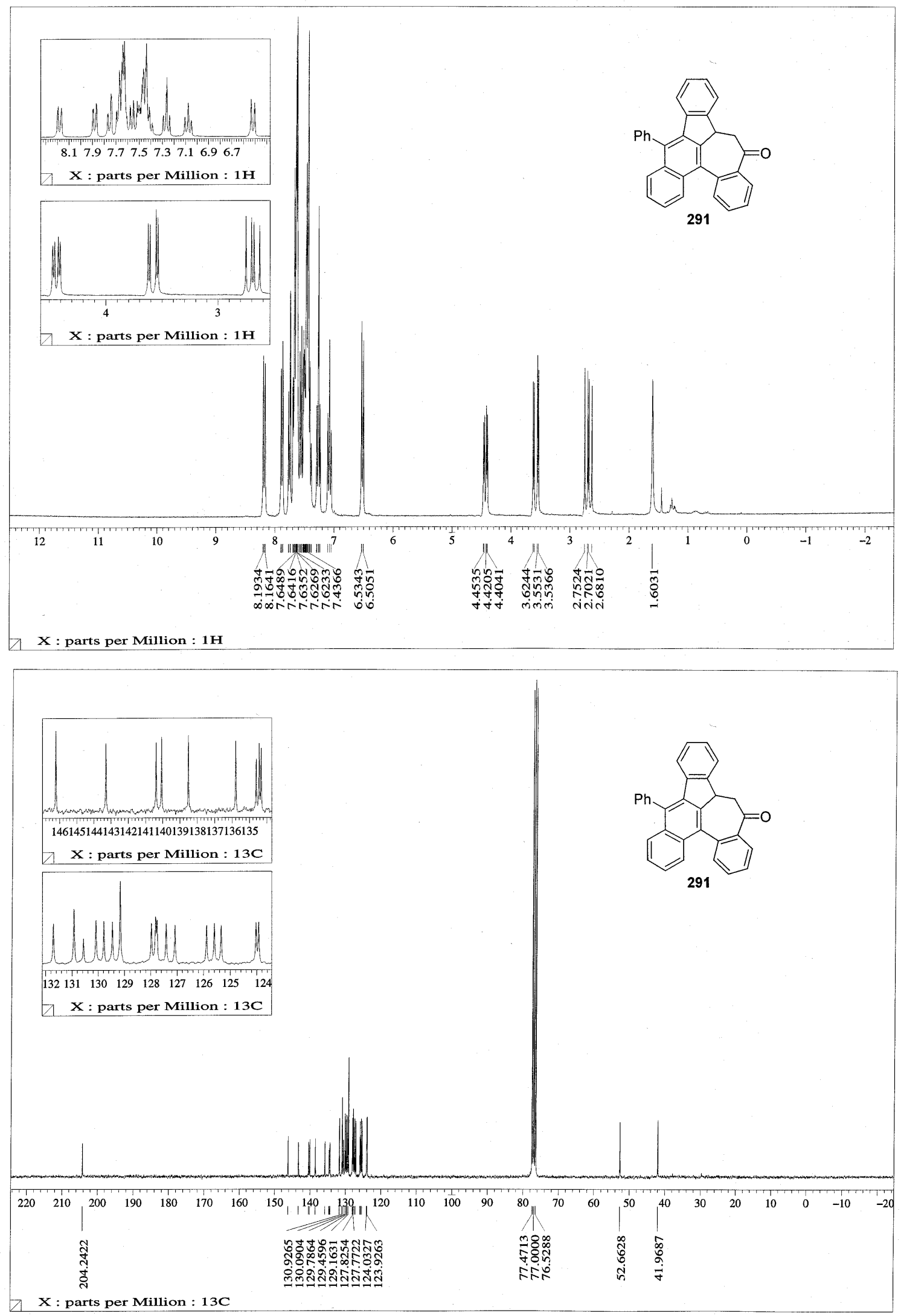

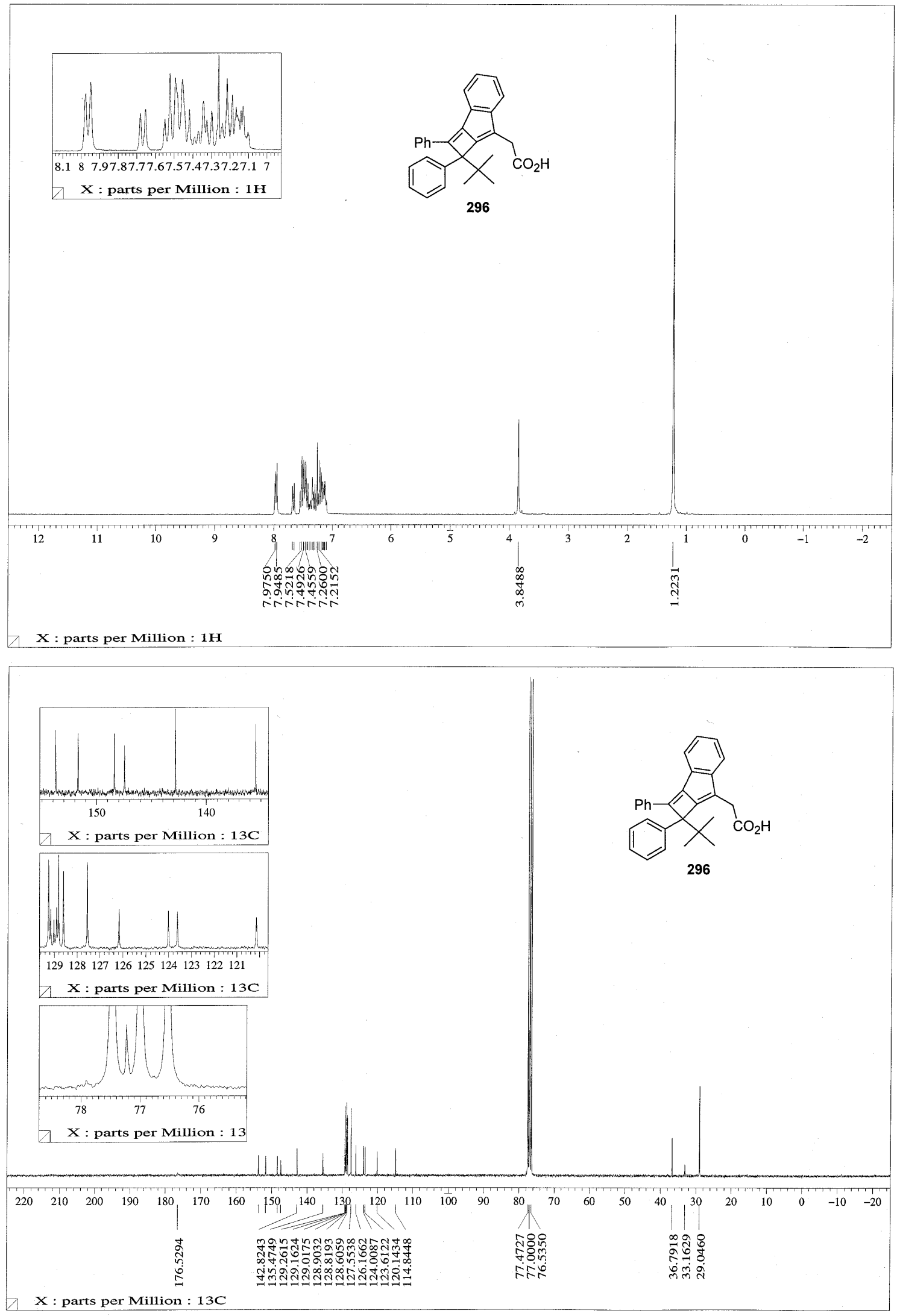

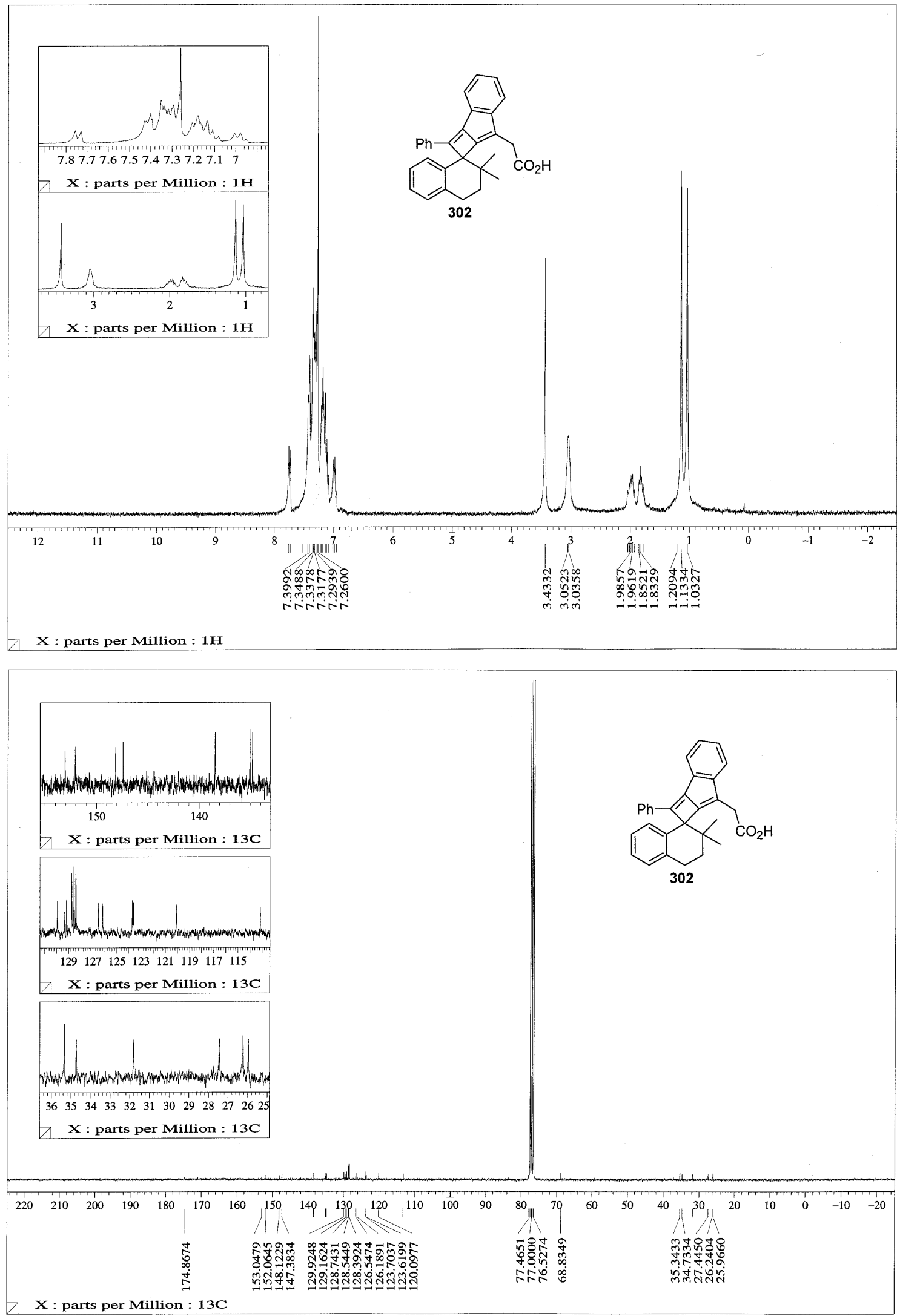

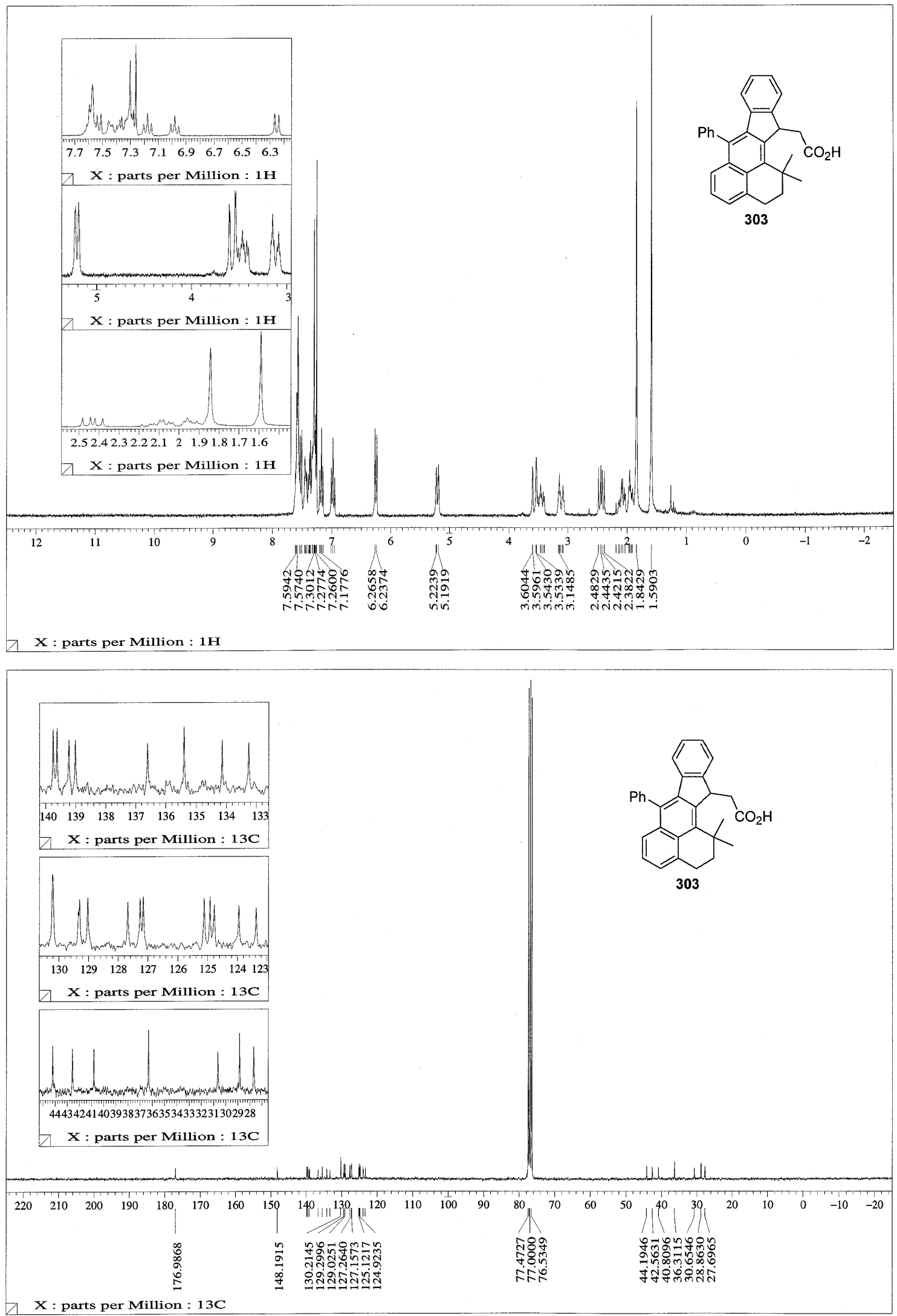

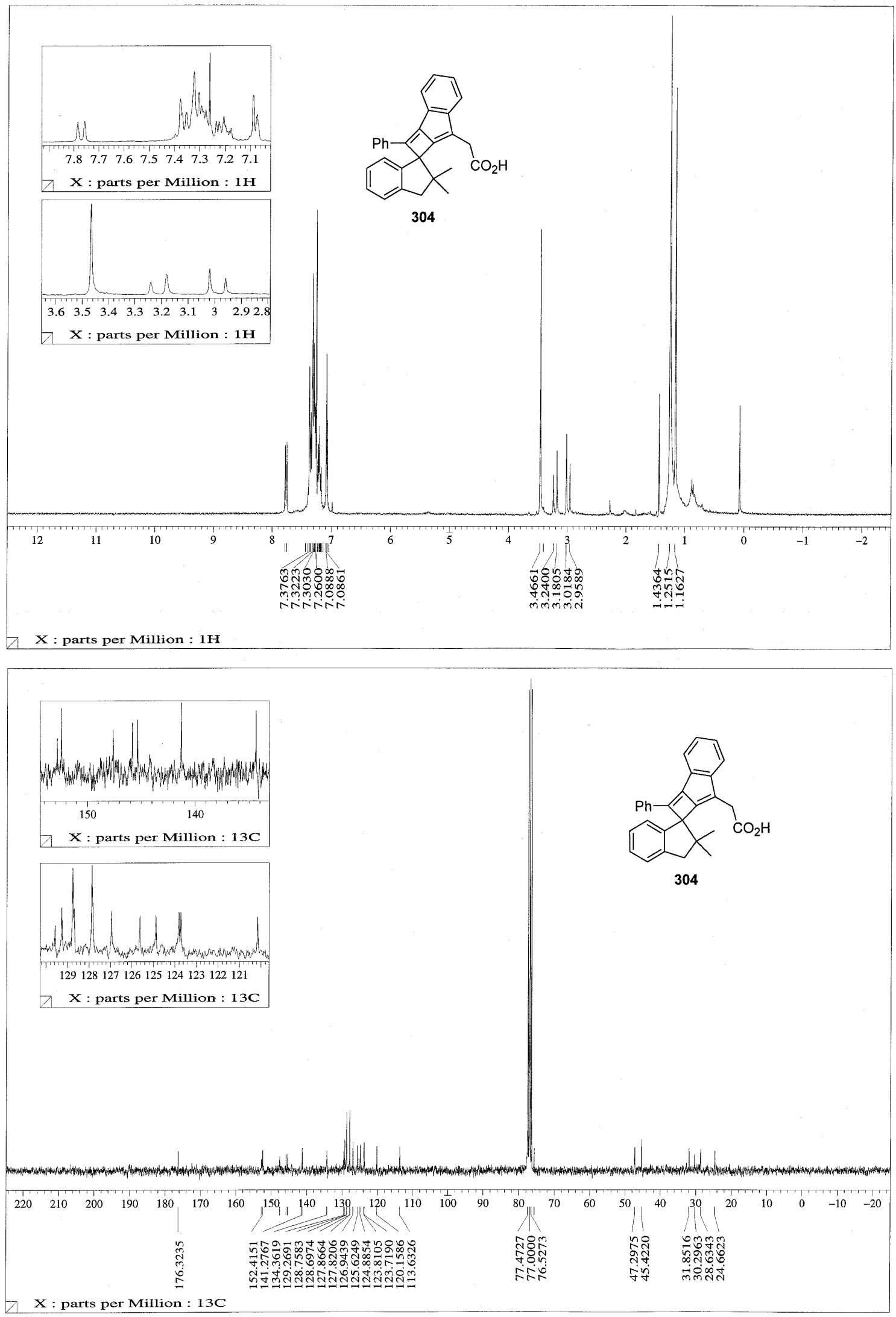

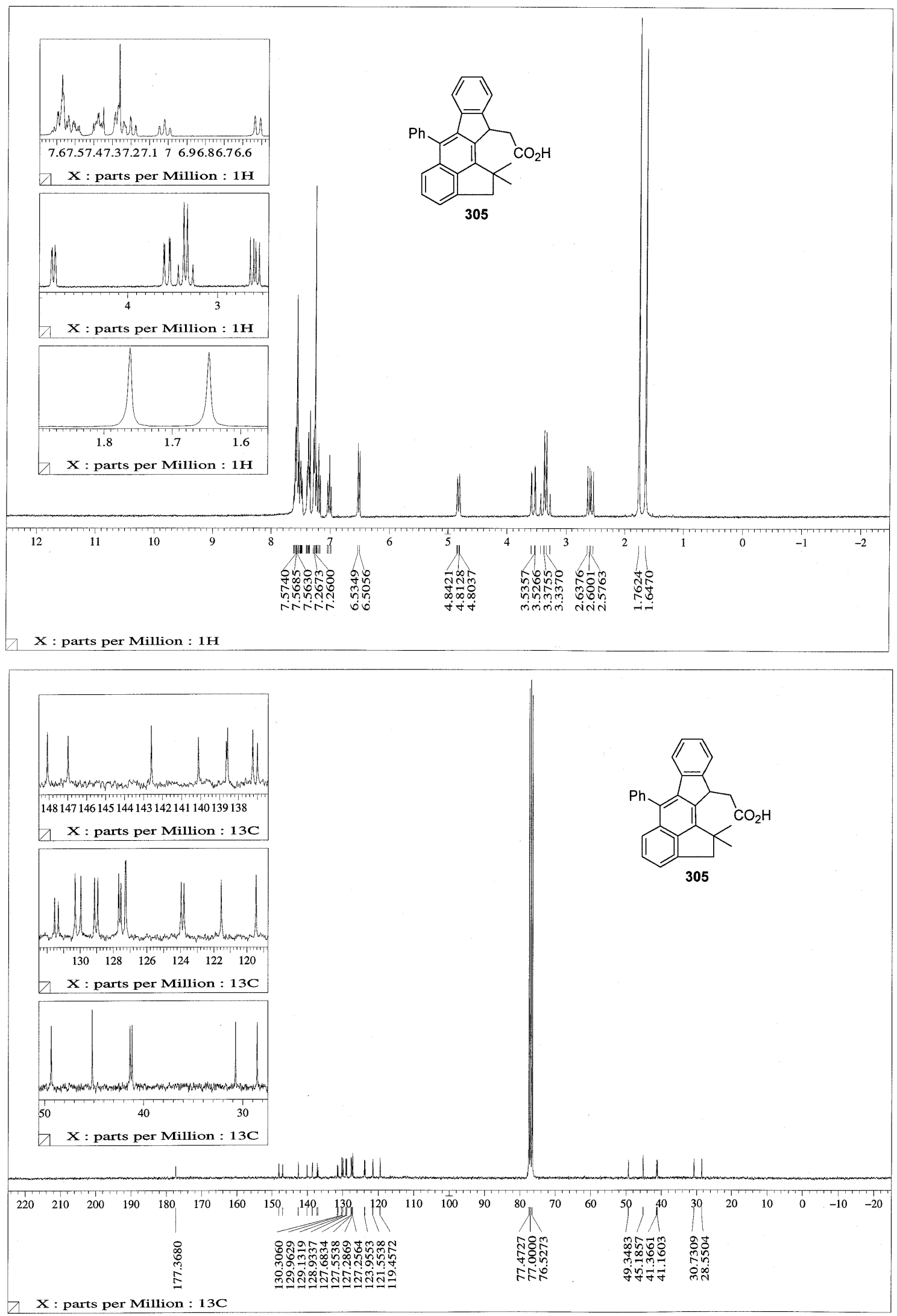

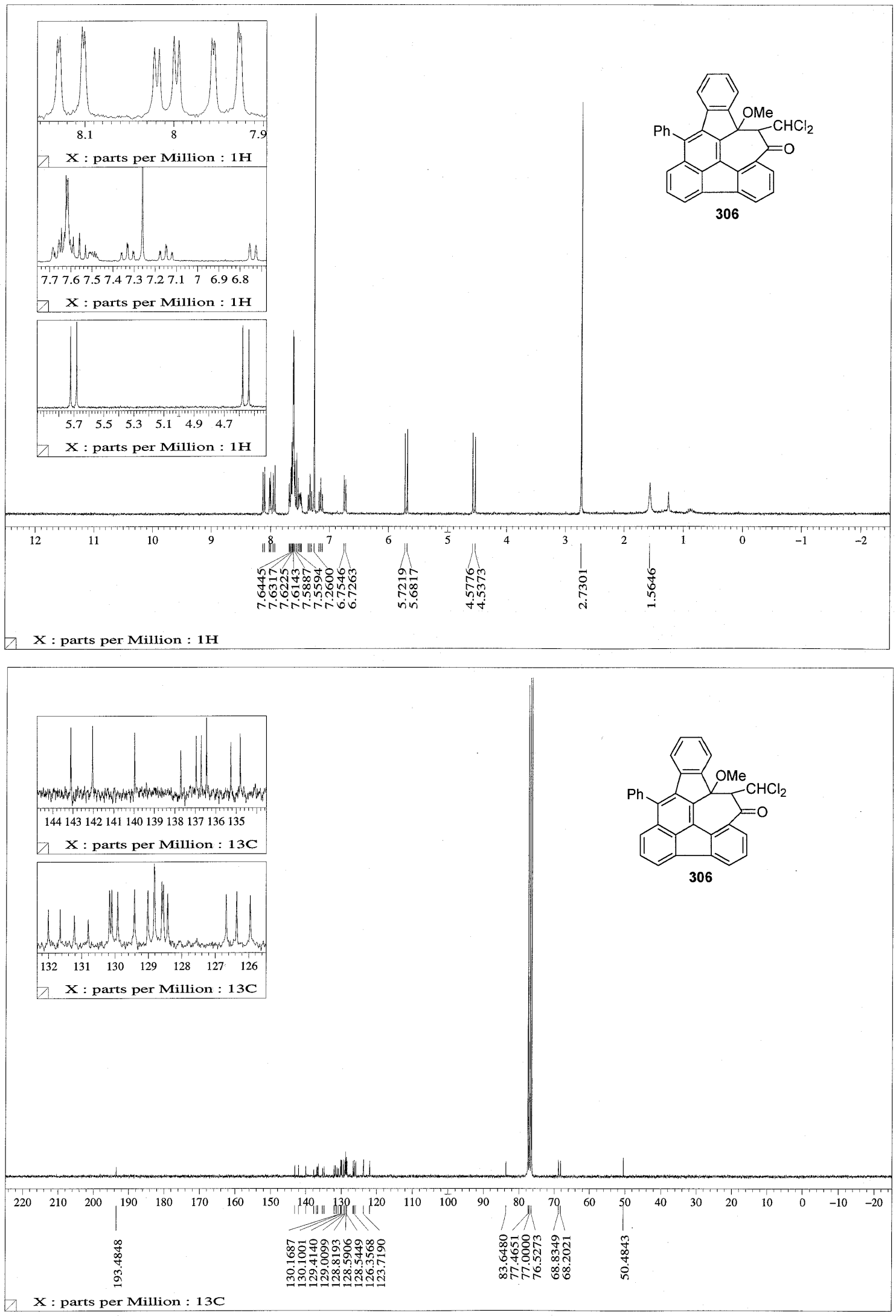


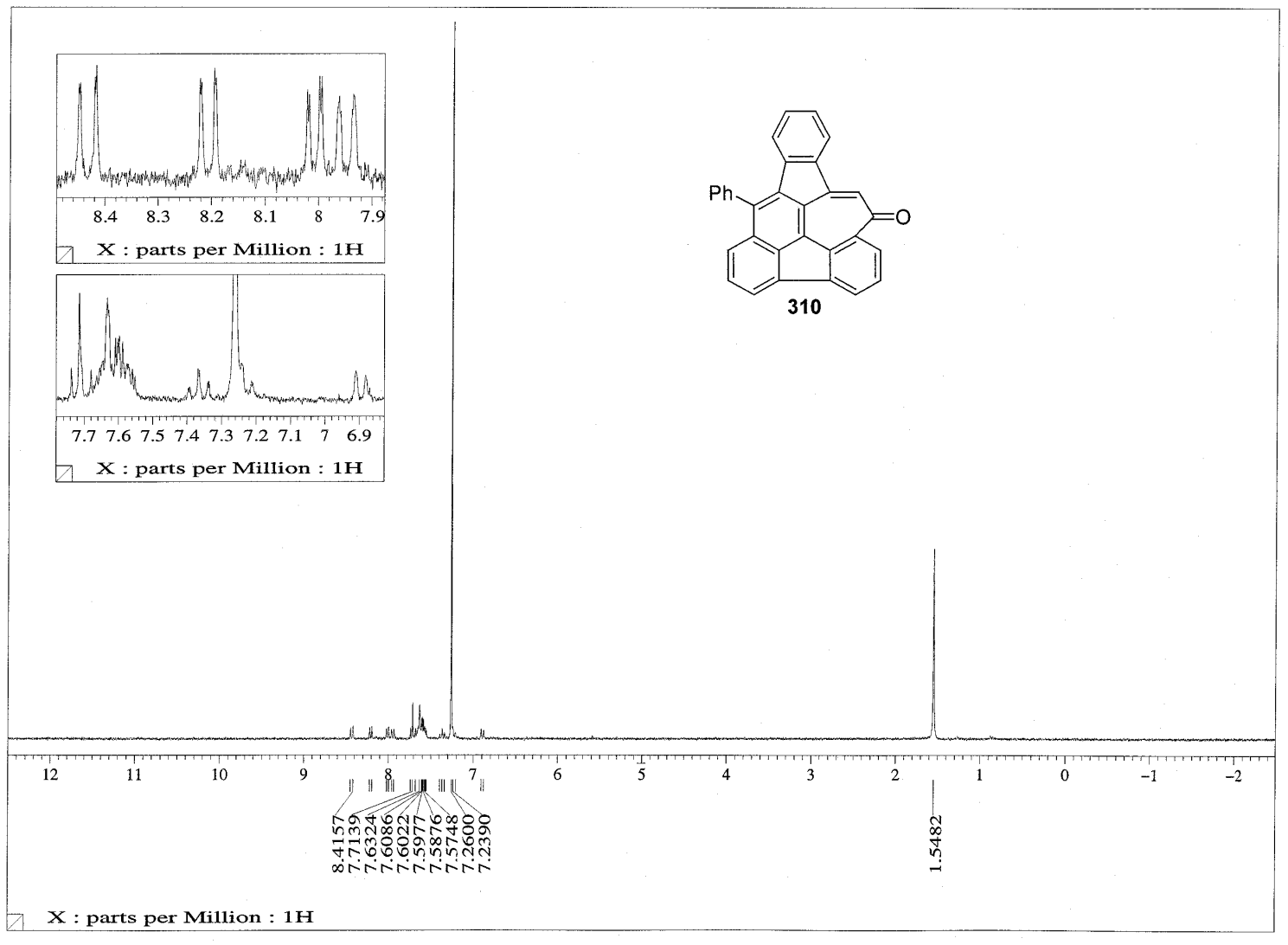



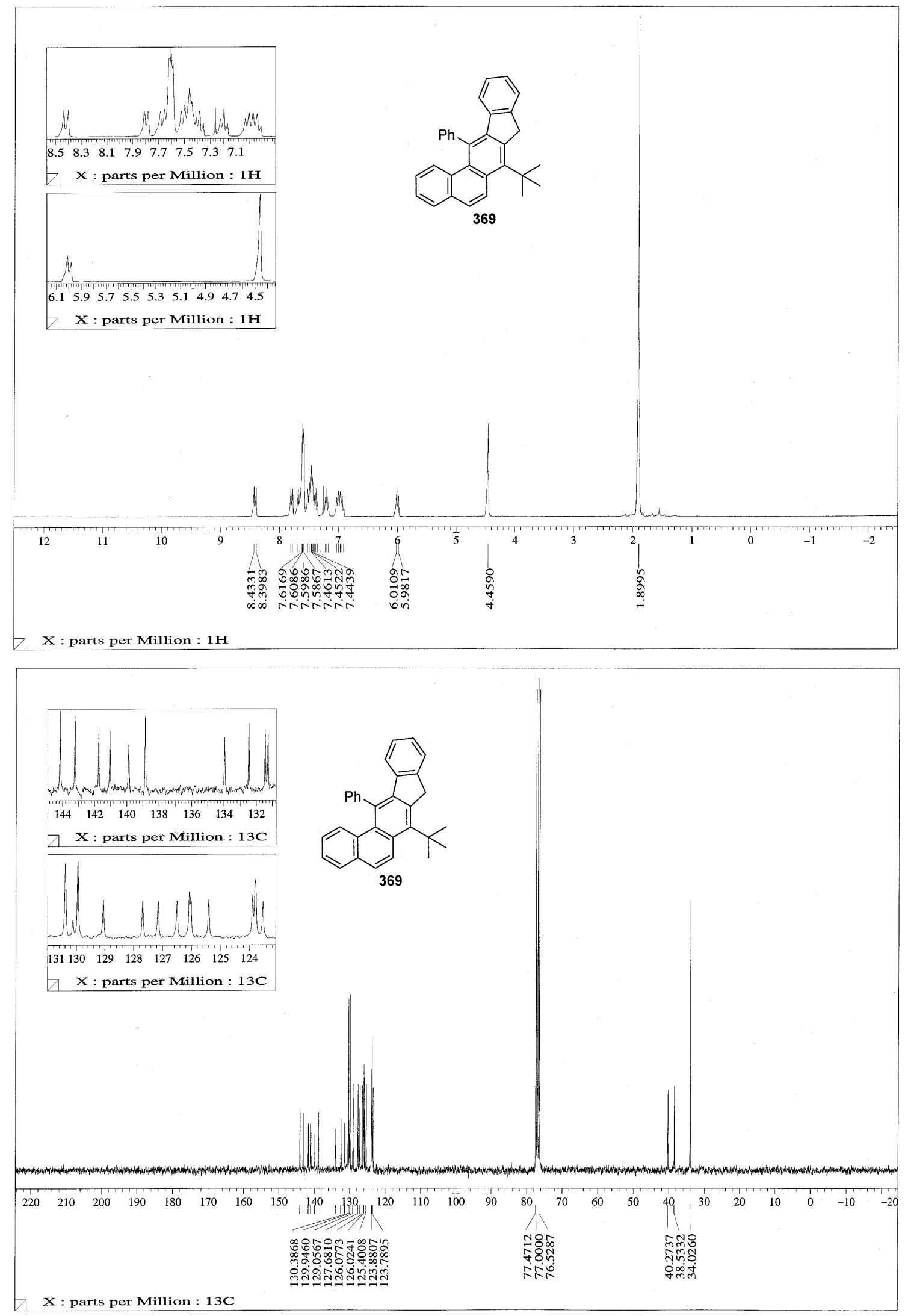

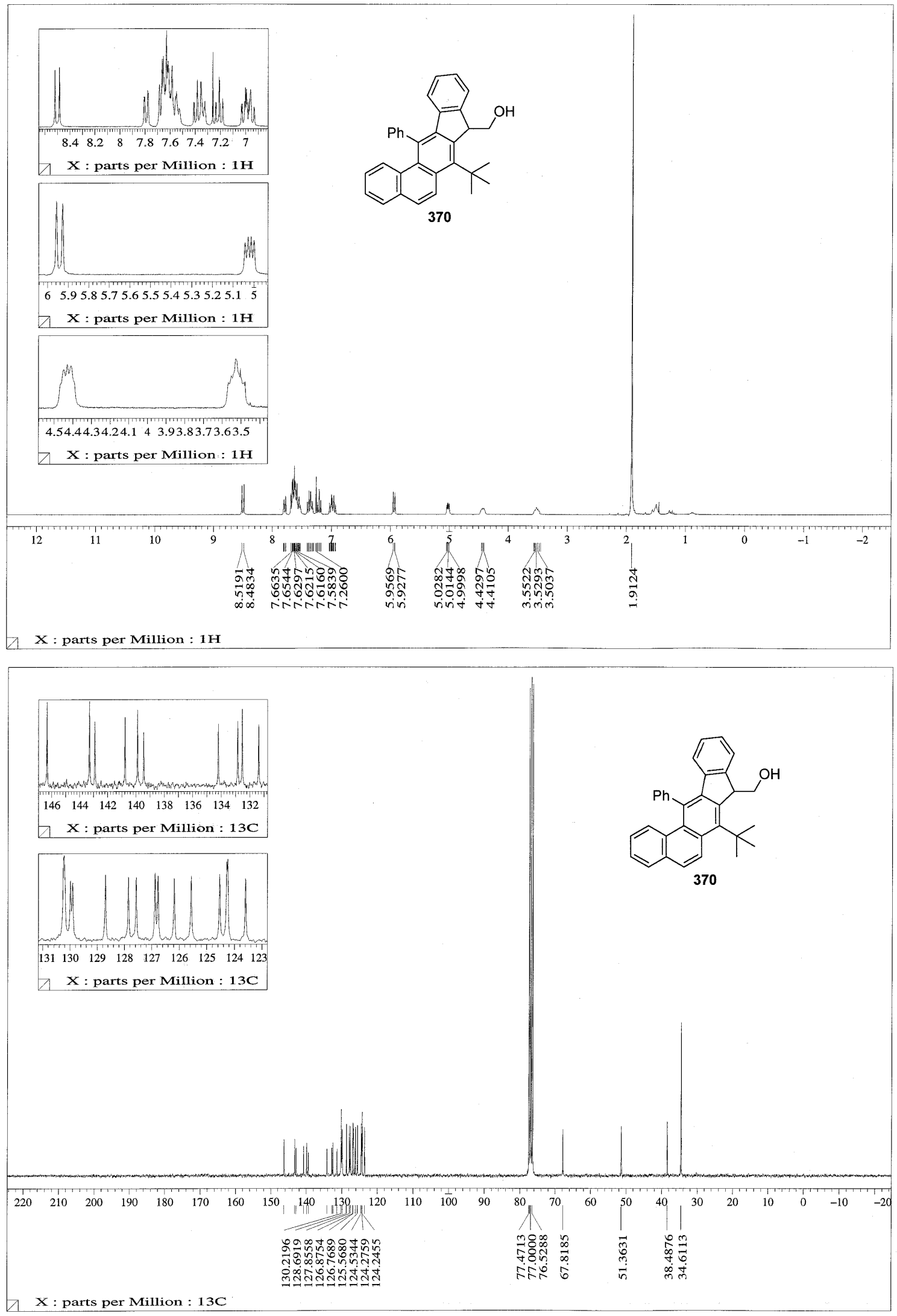

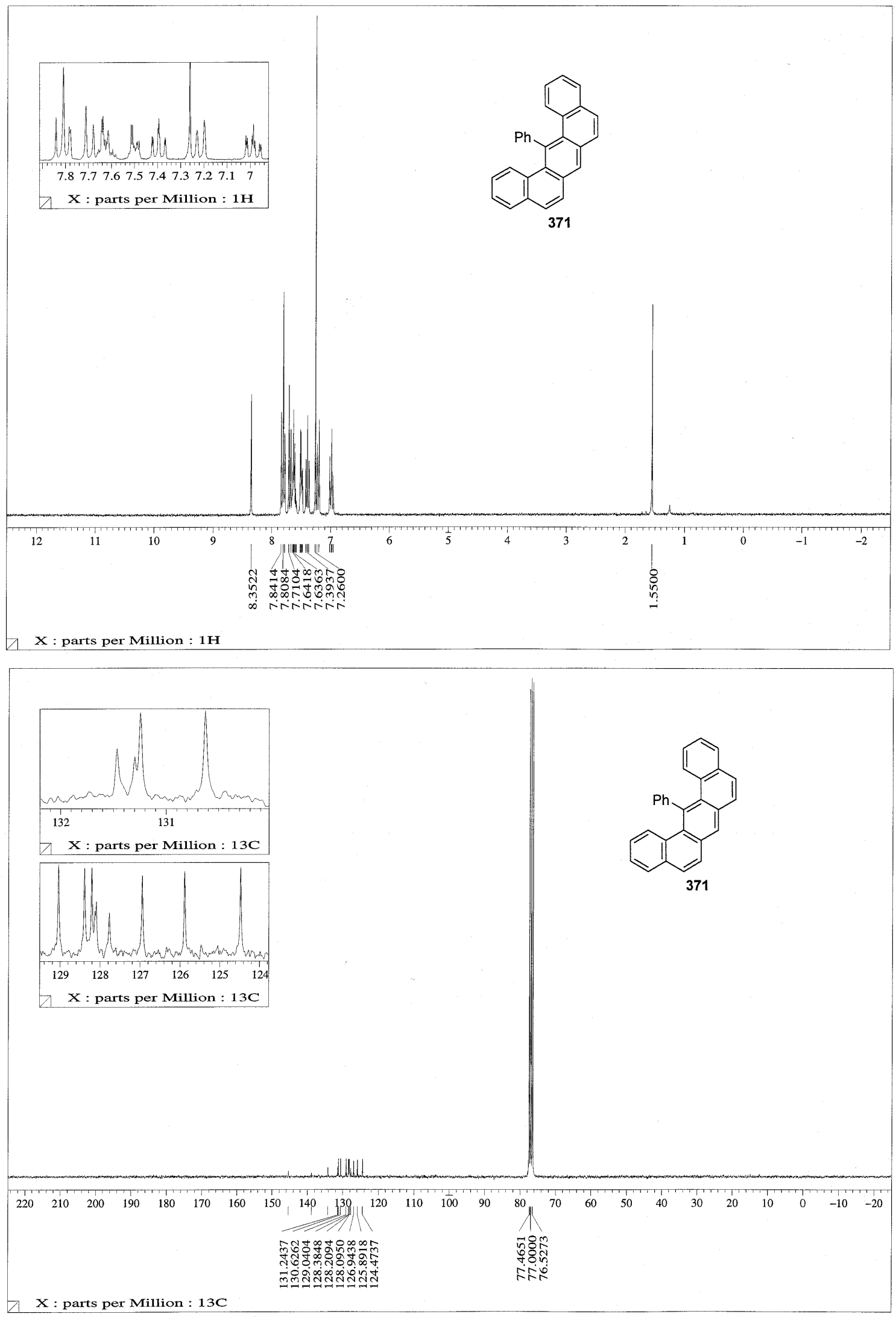

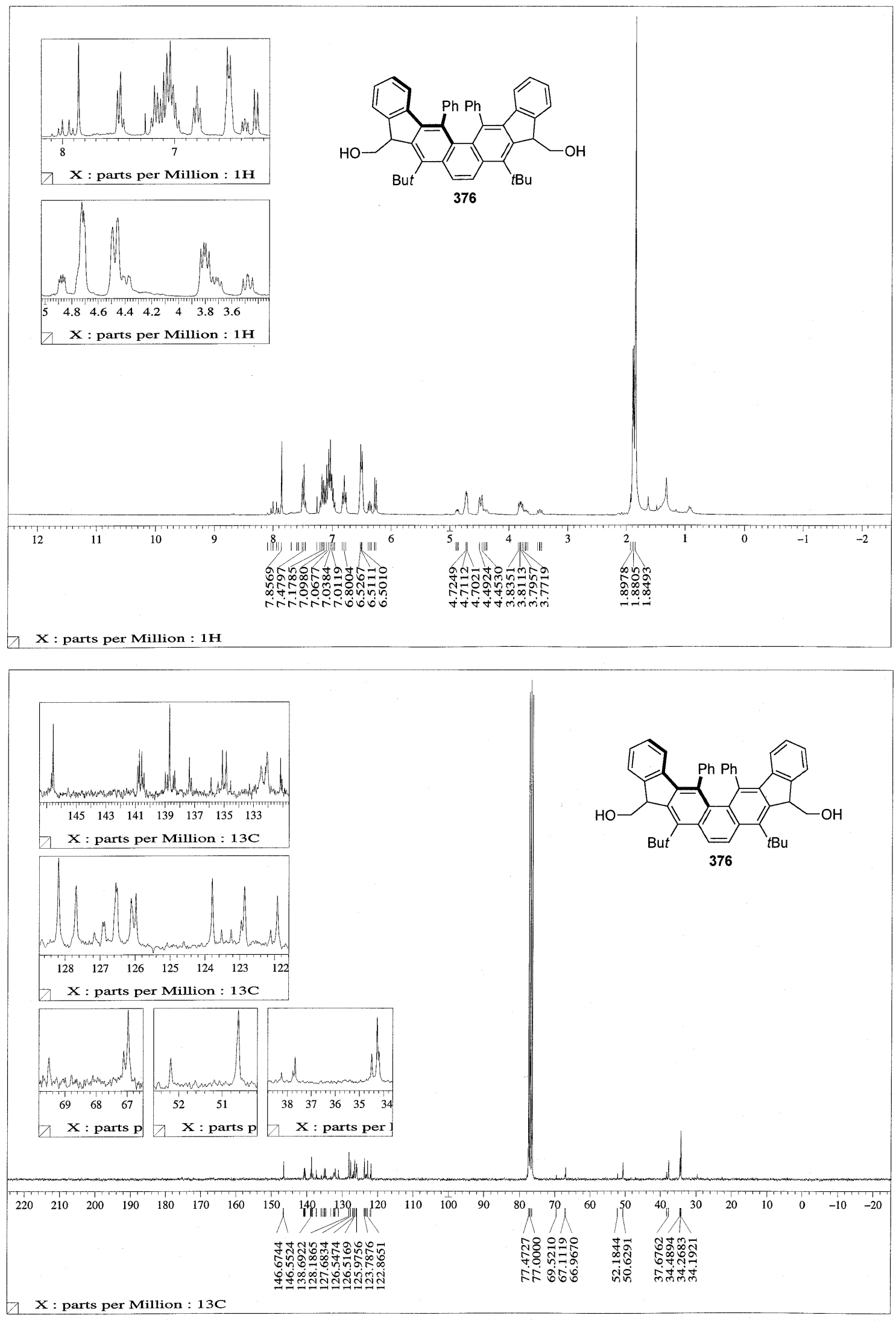

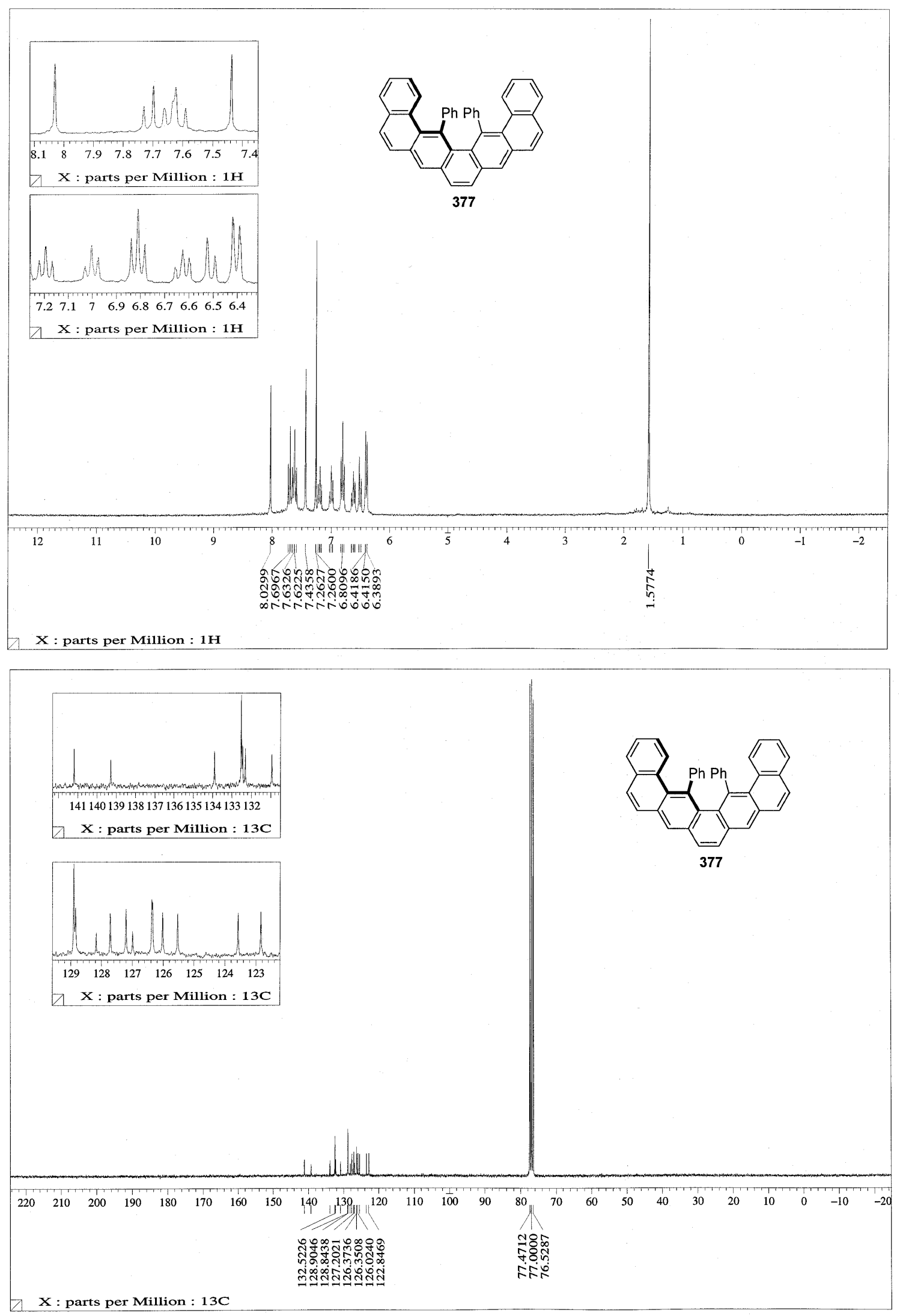

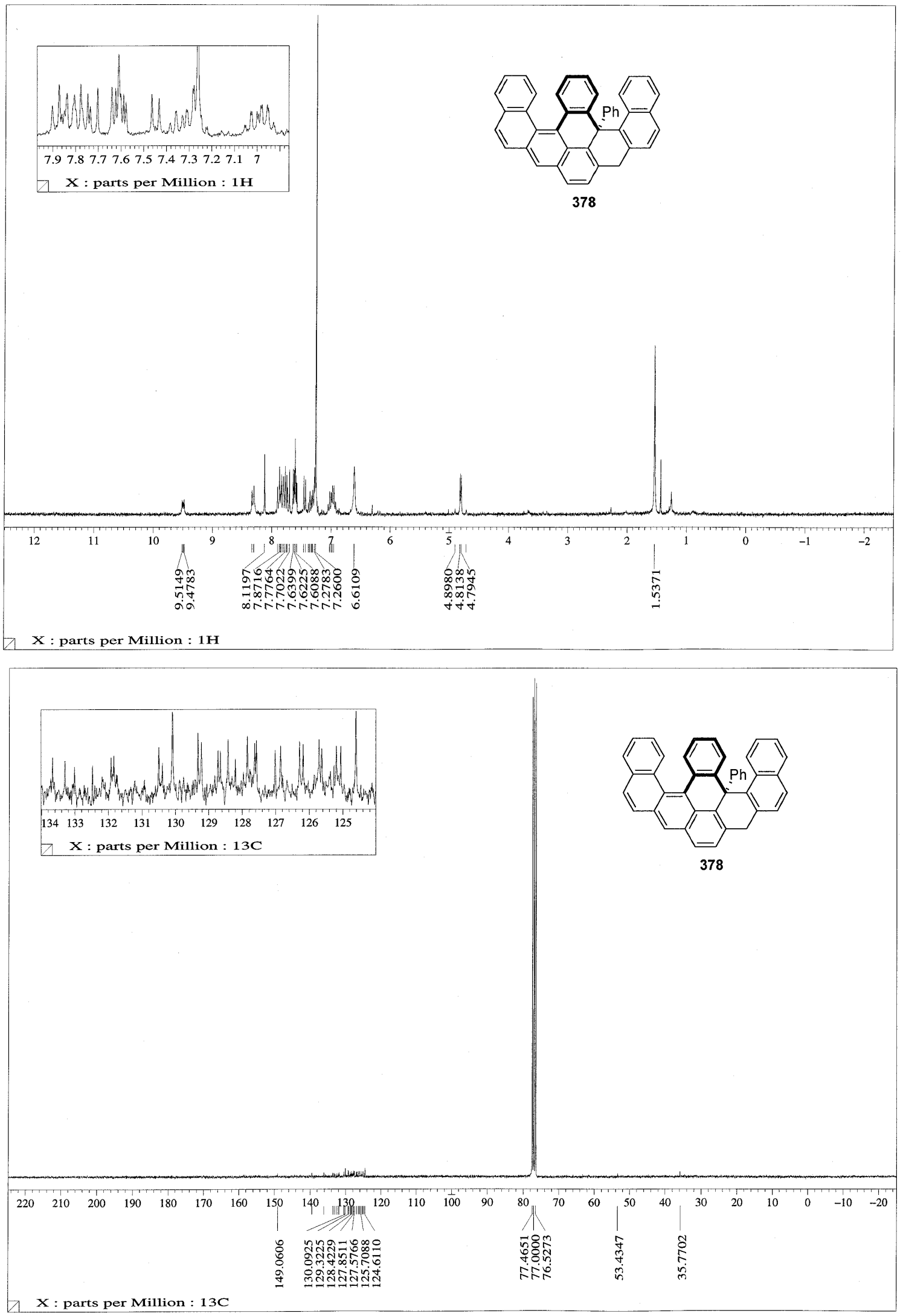

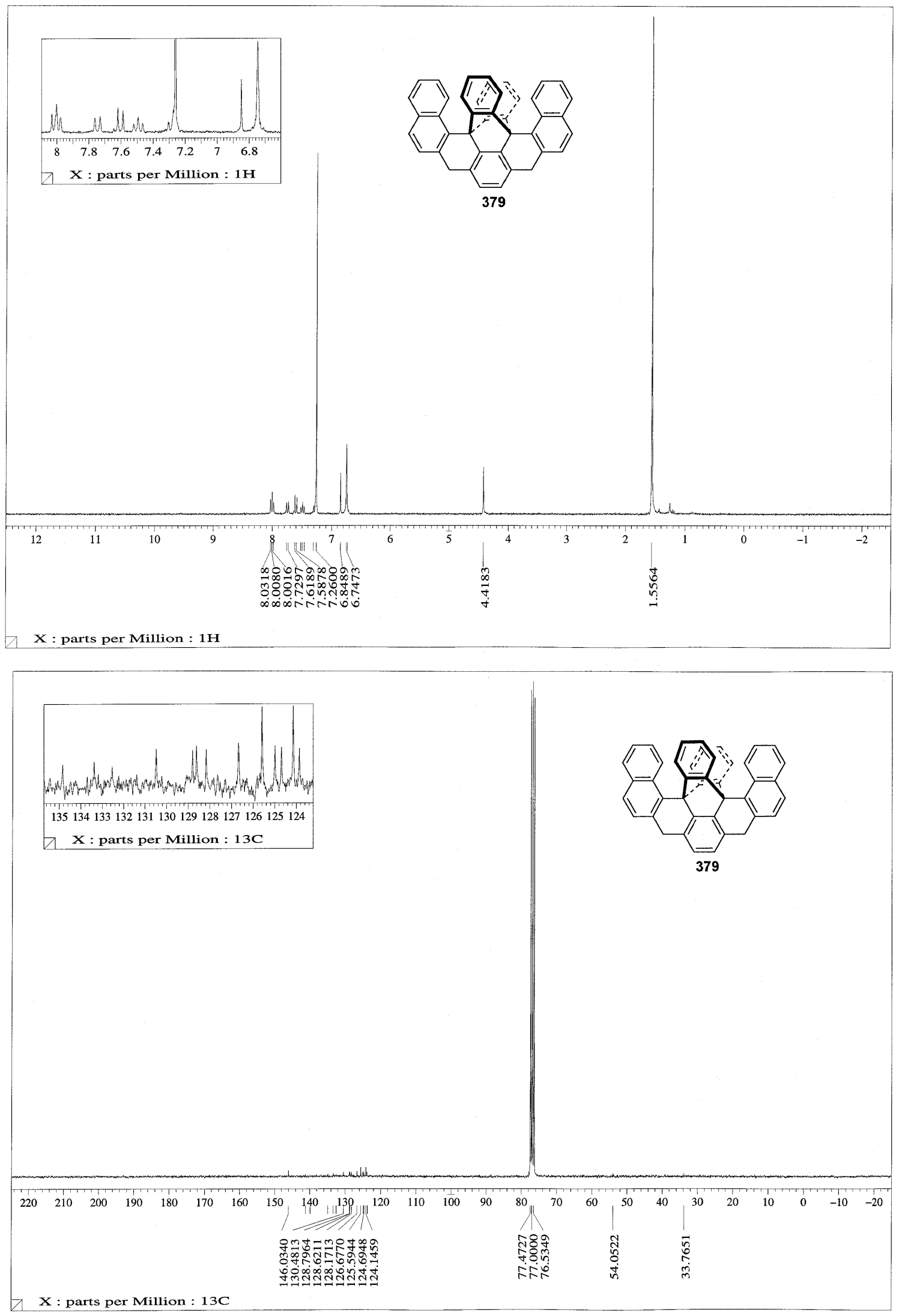

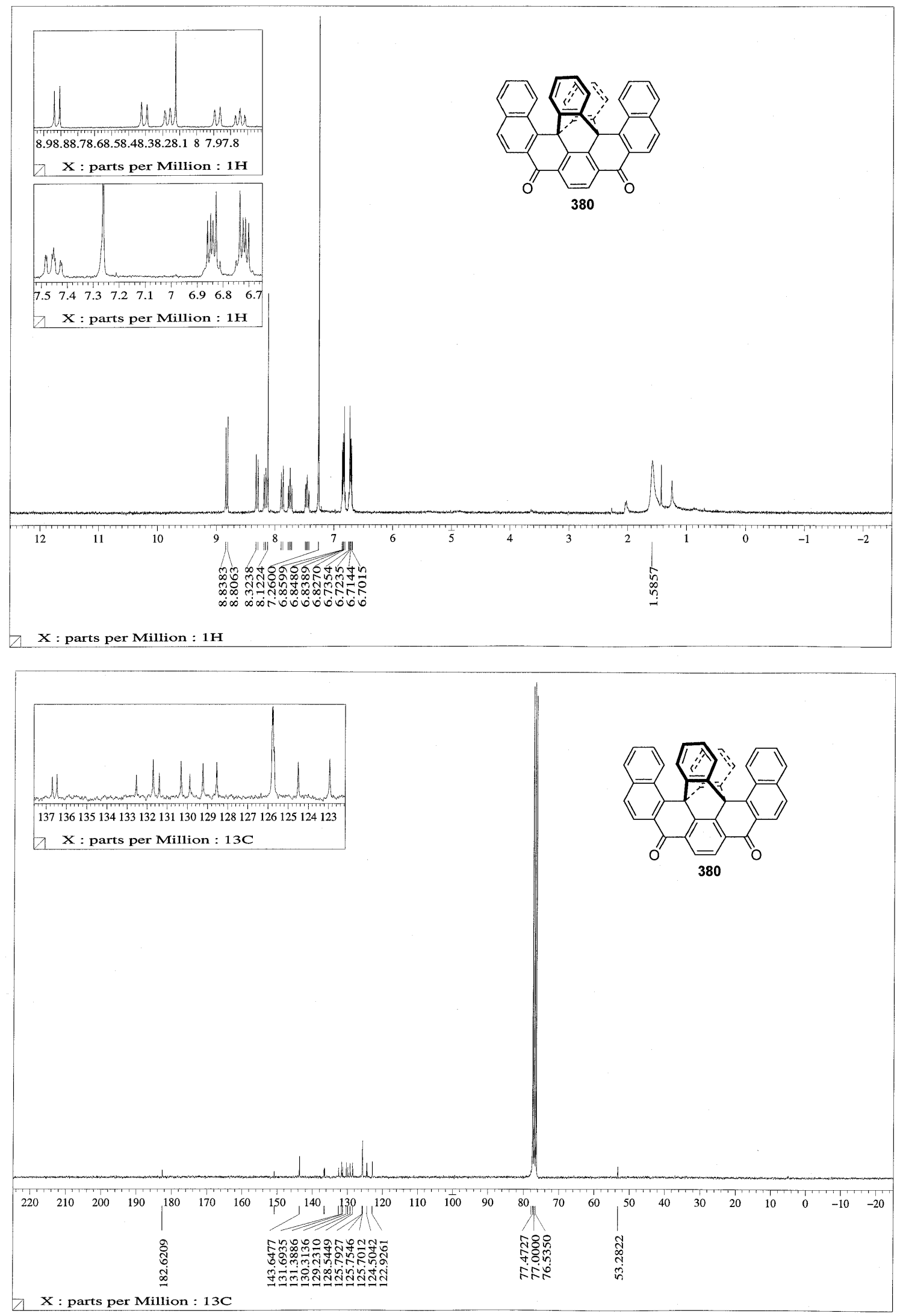

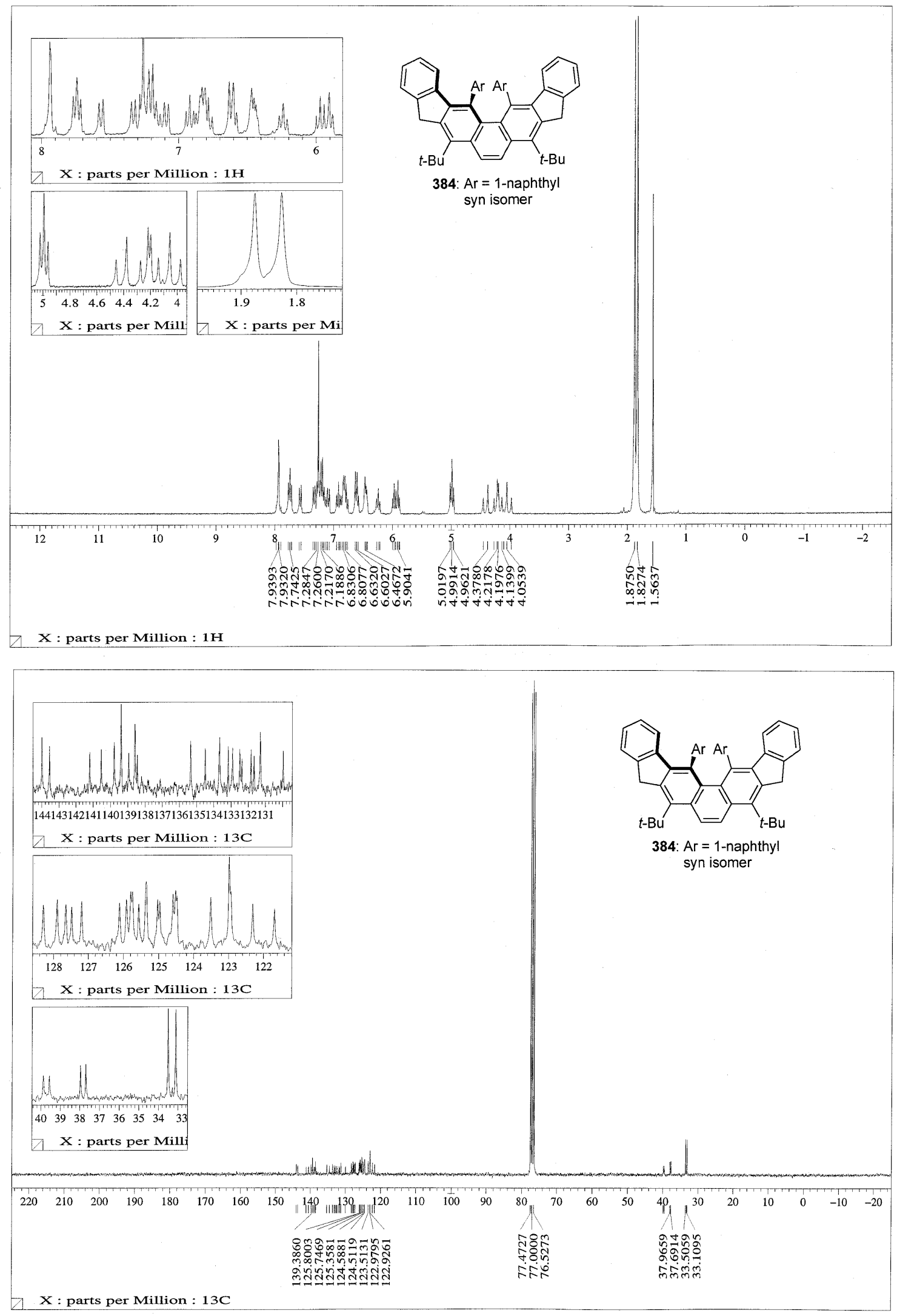

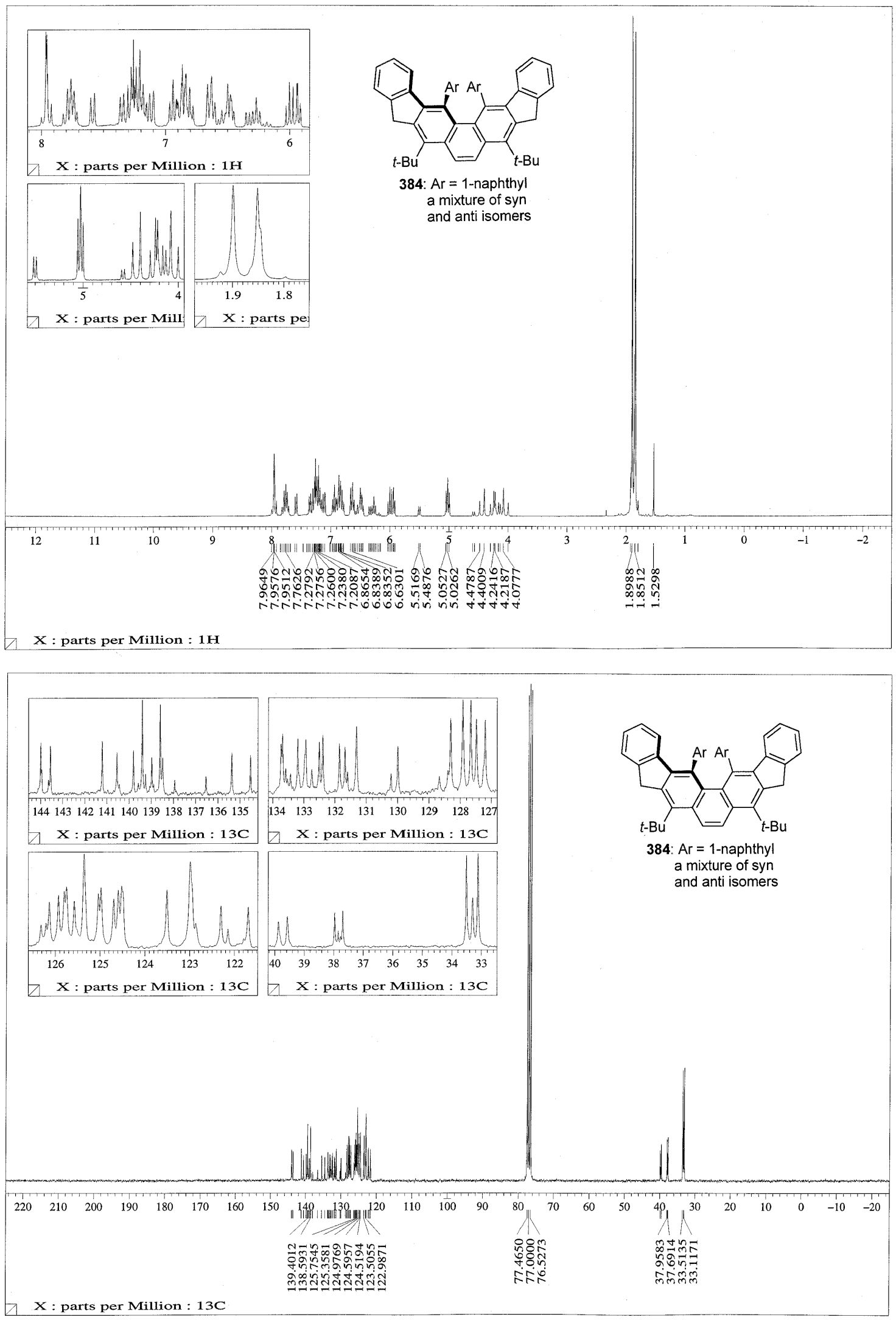

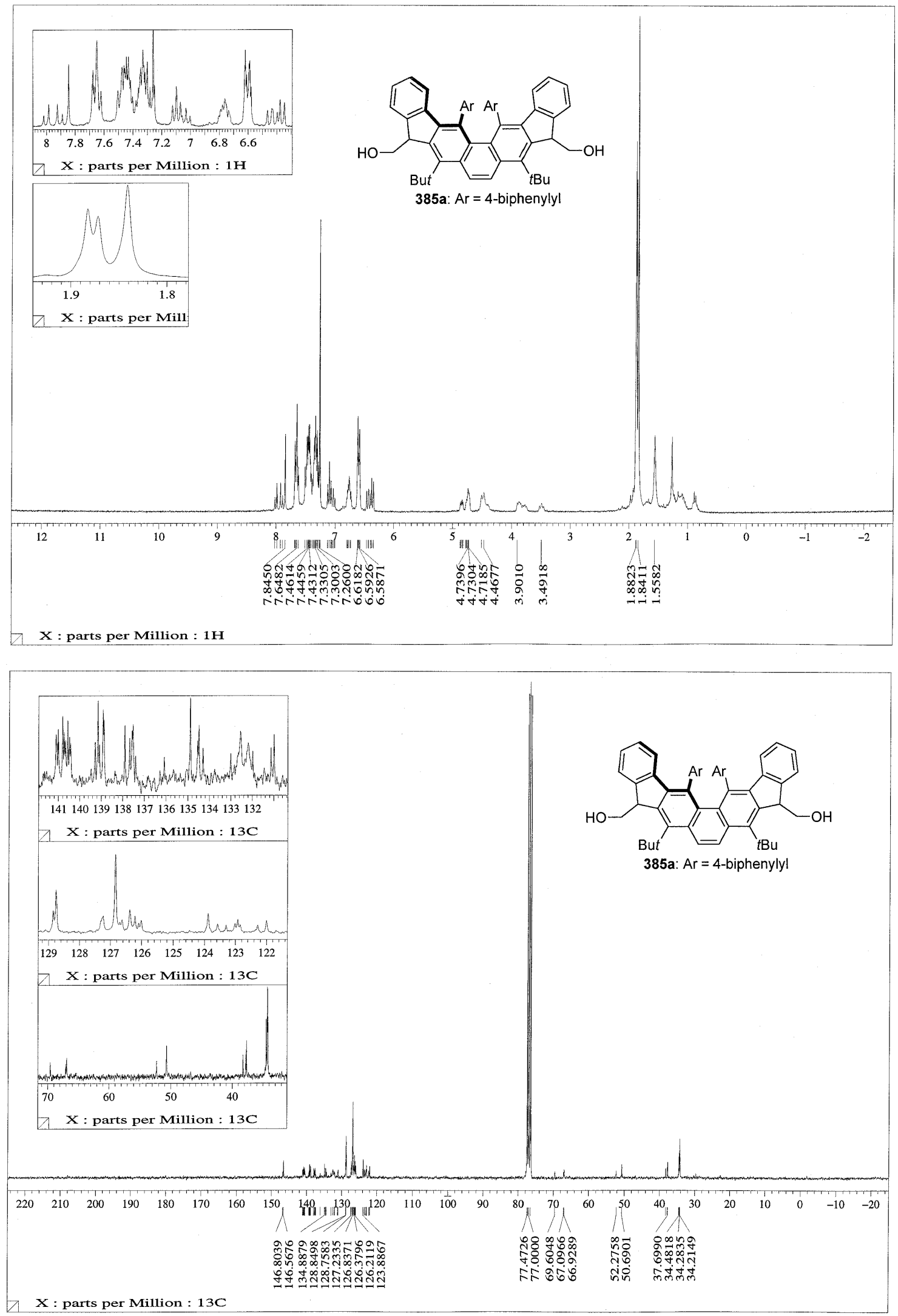

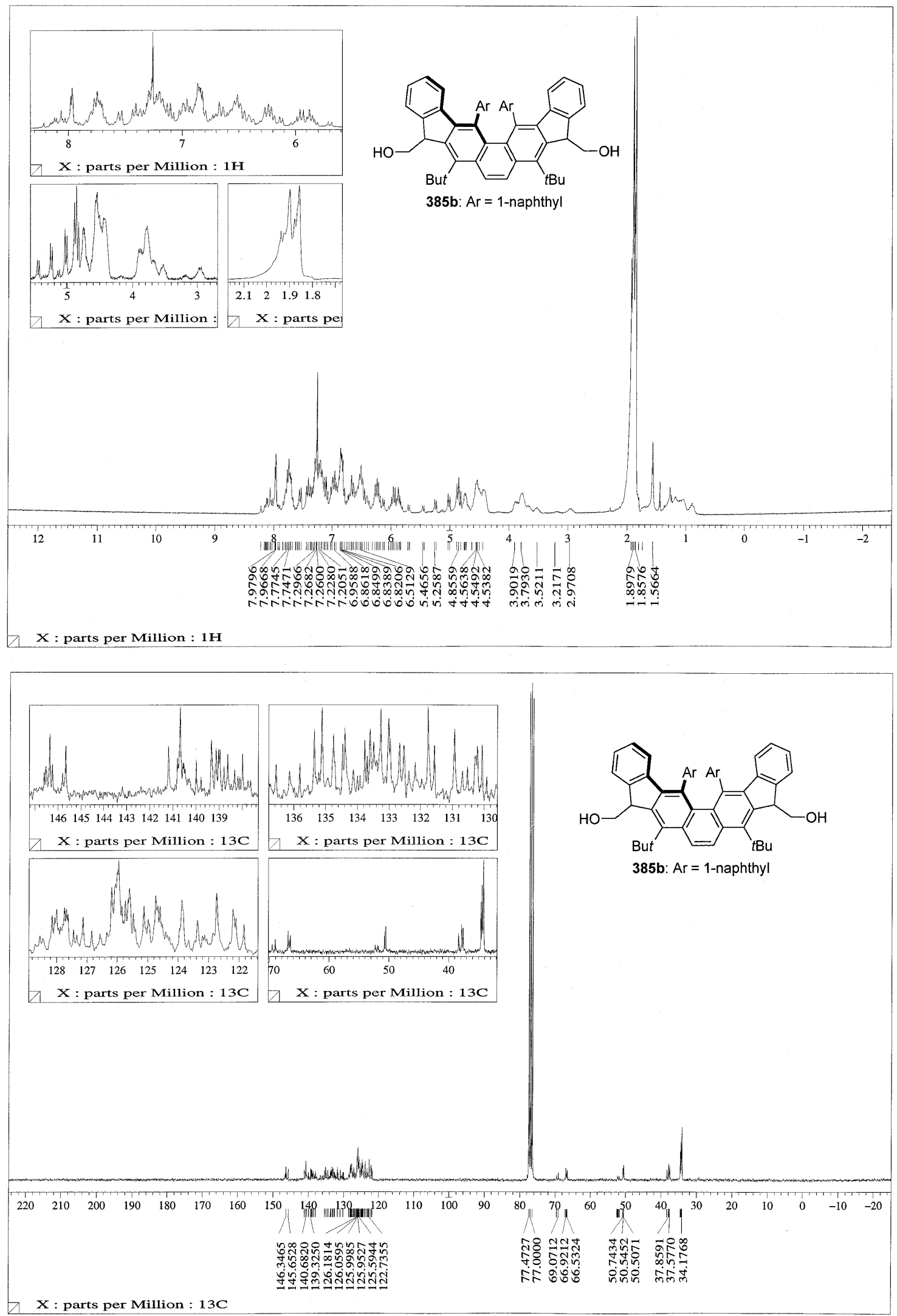

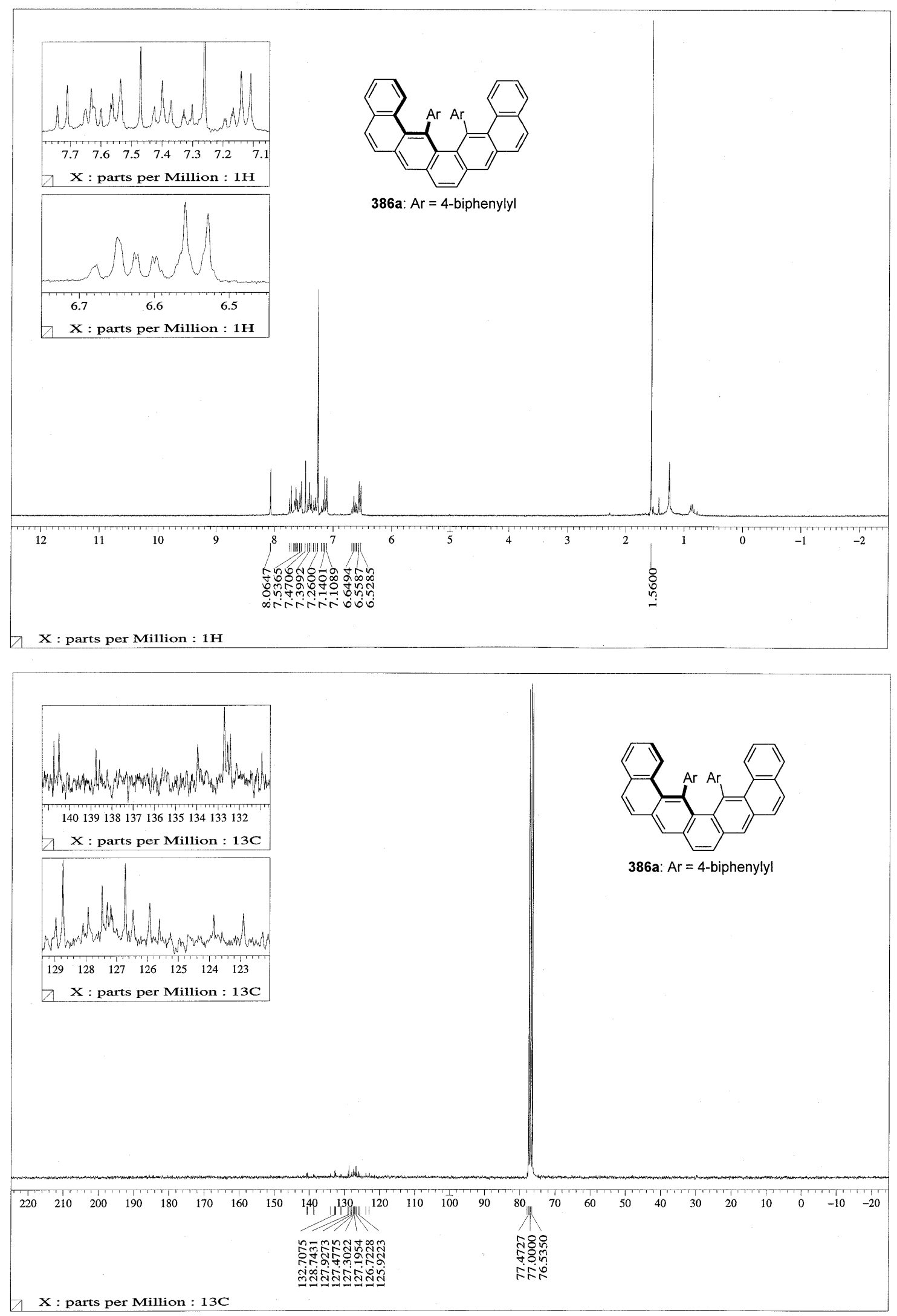

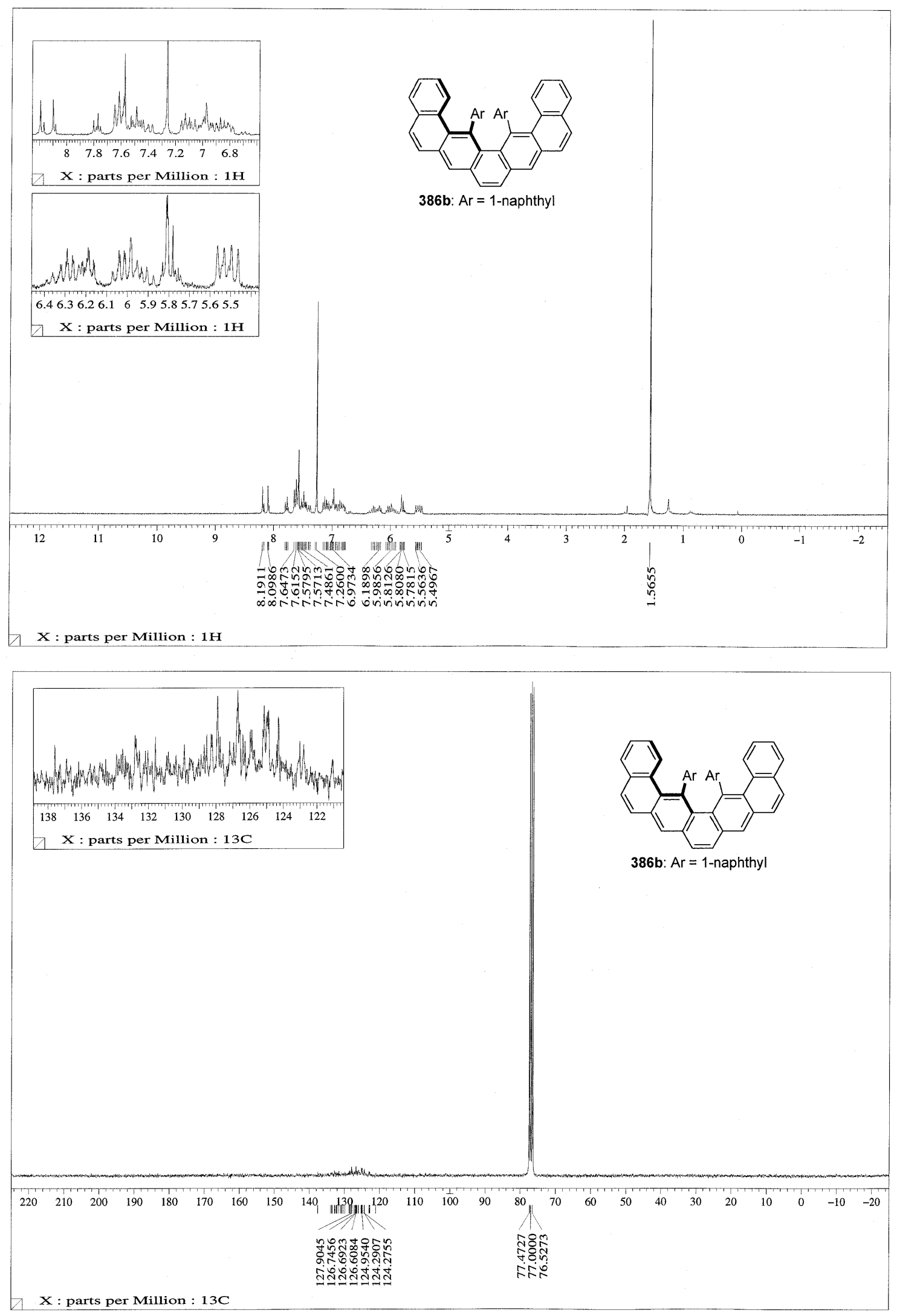

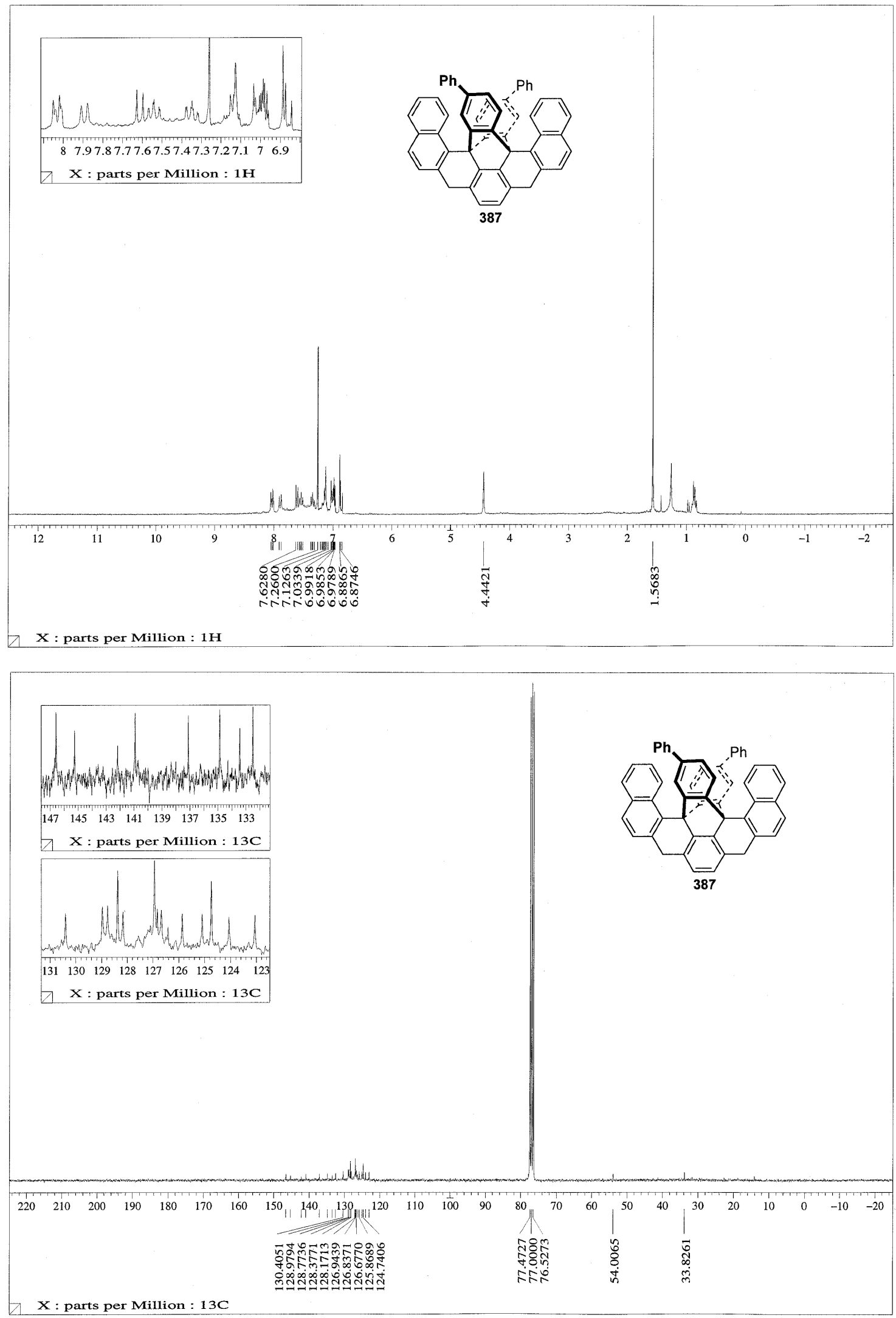

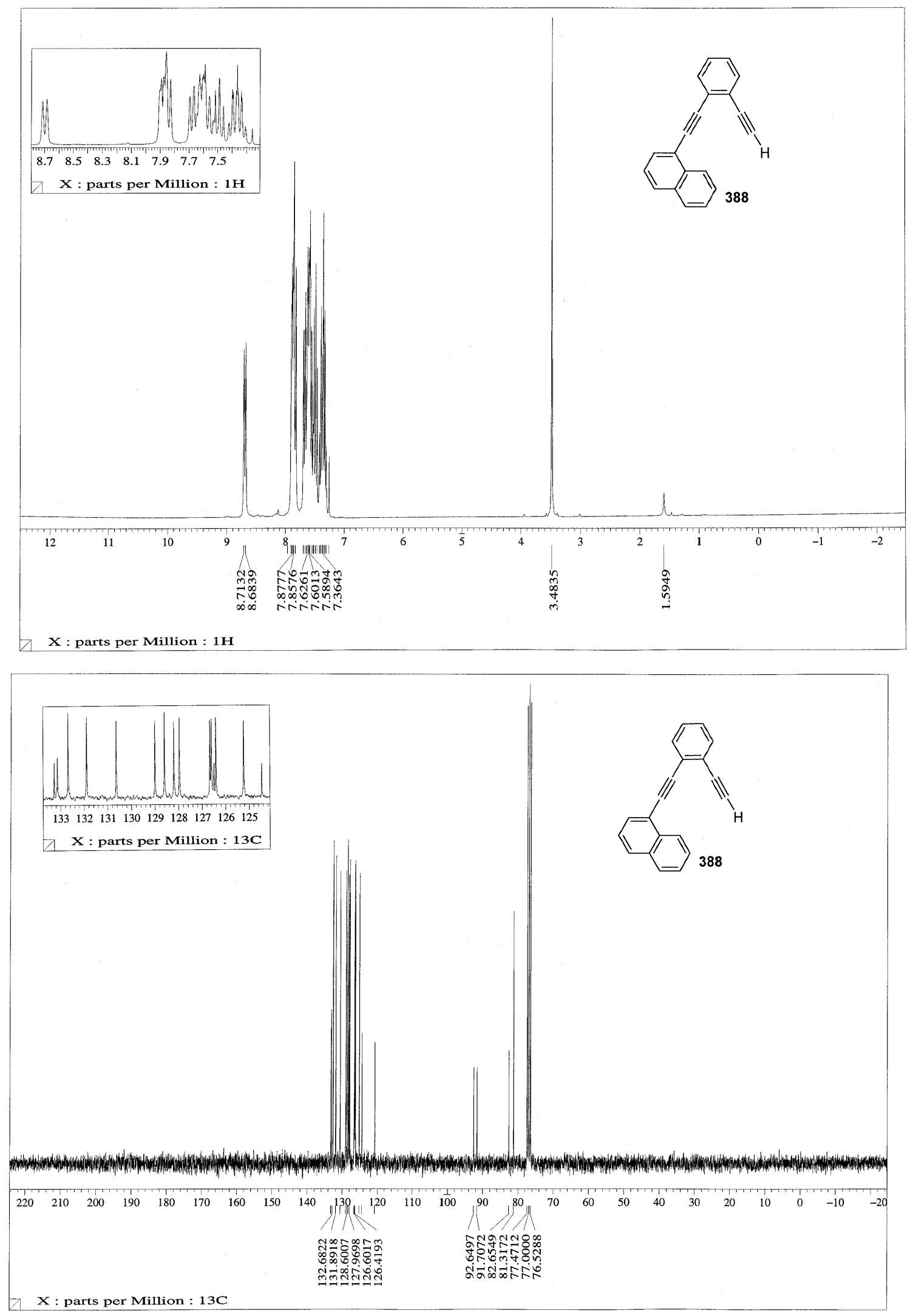

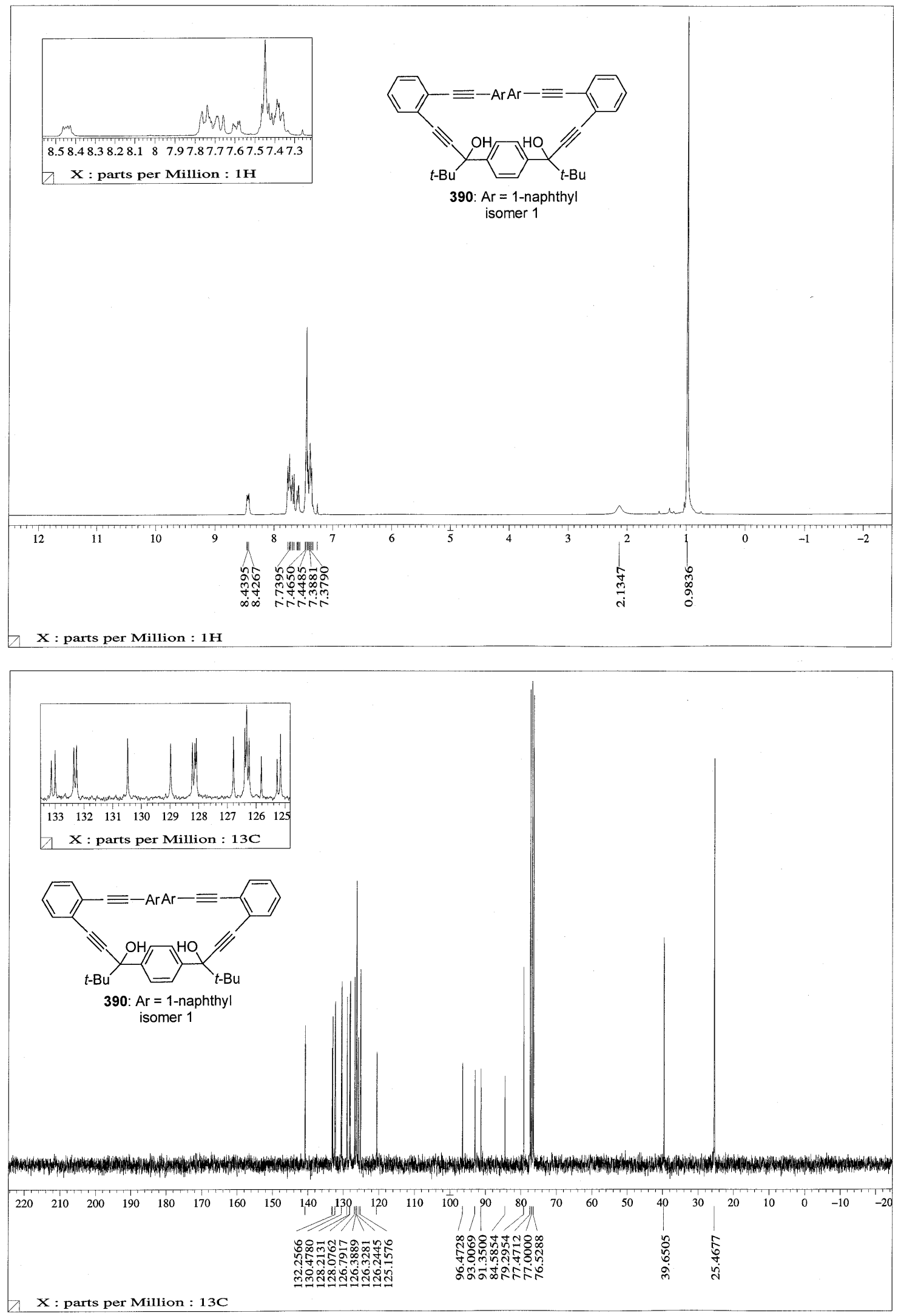

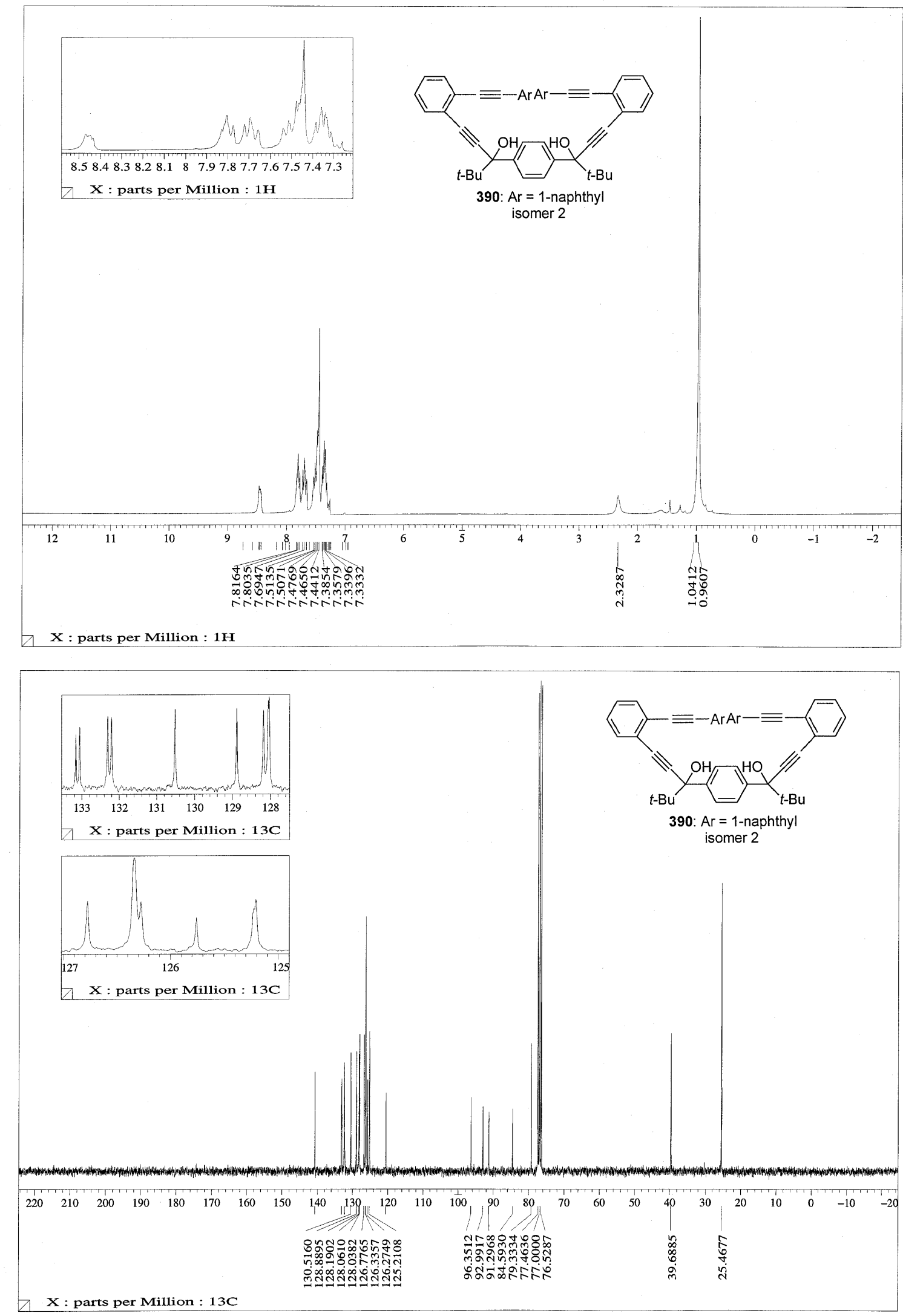

isomer 2 

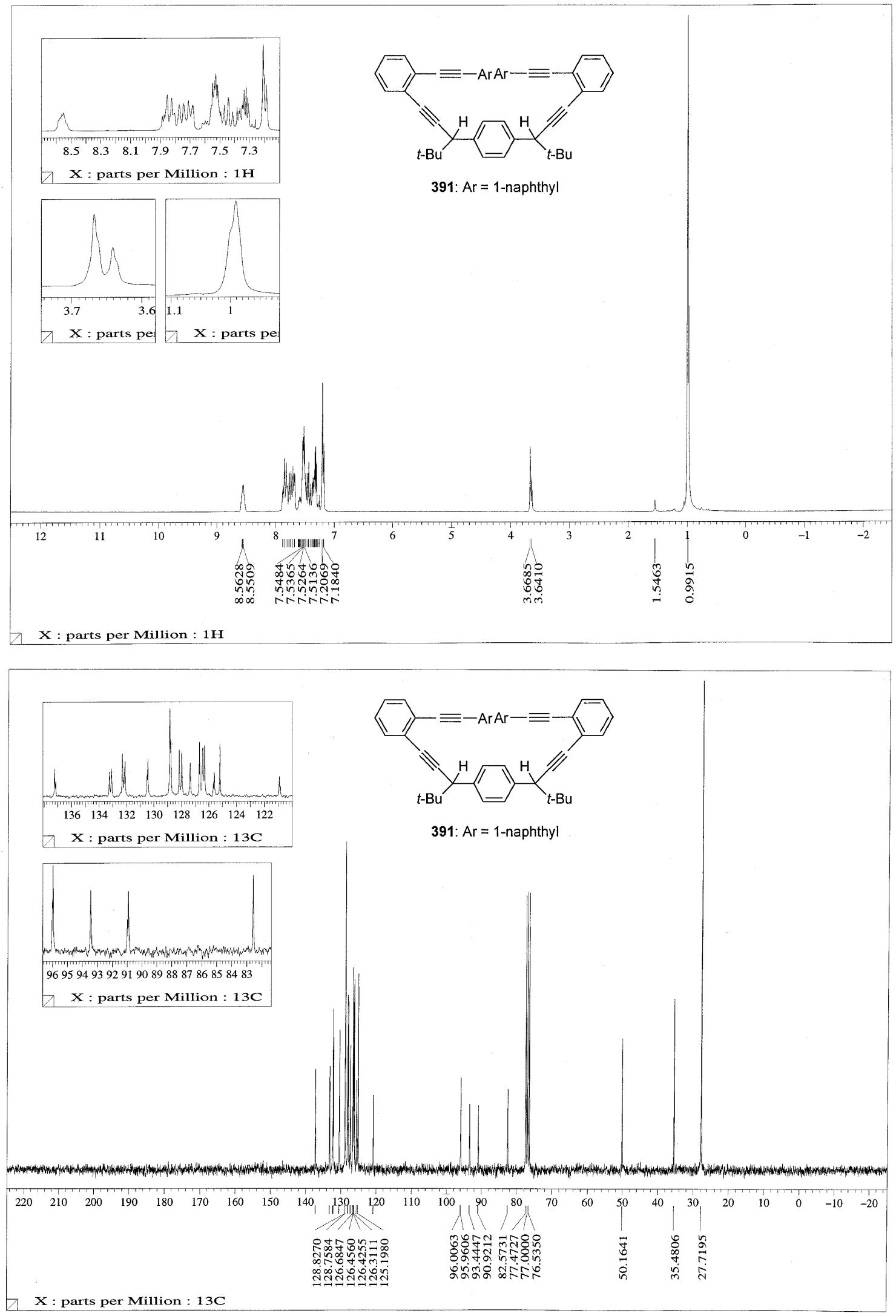

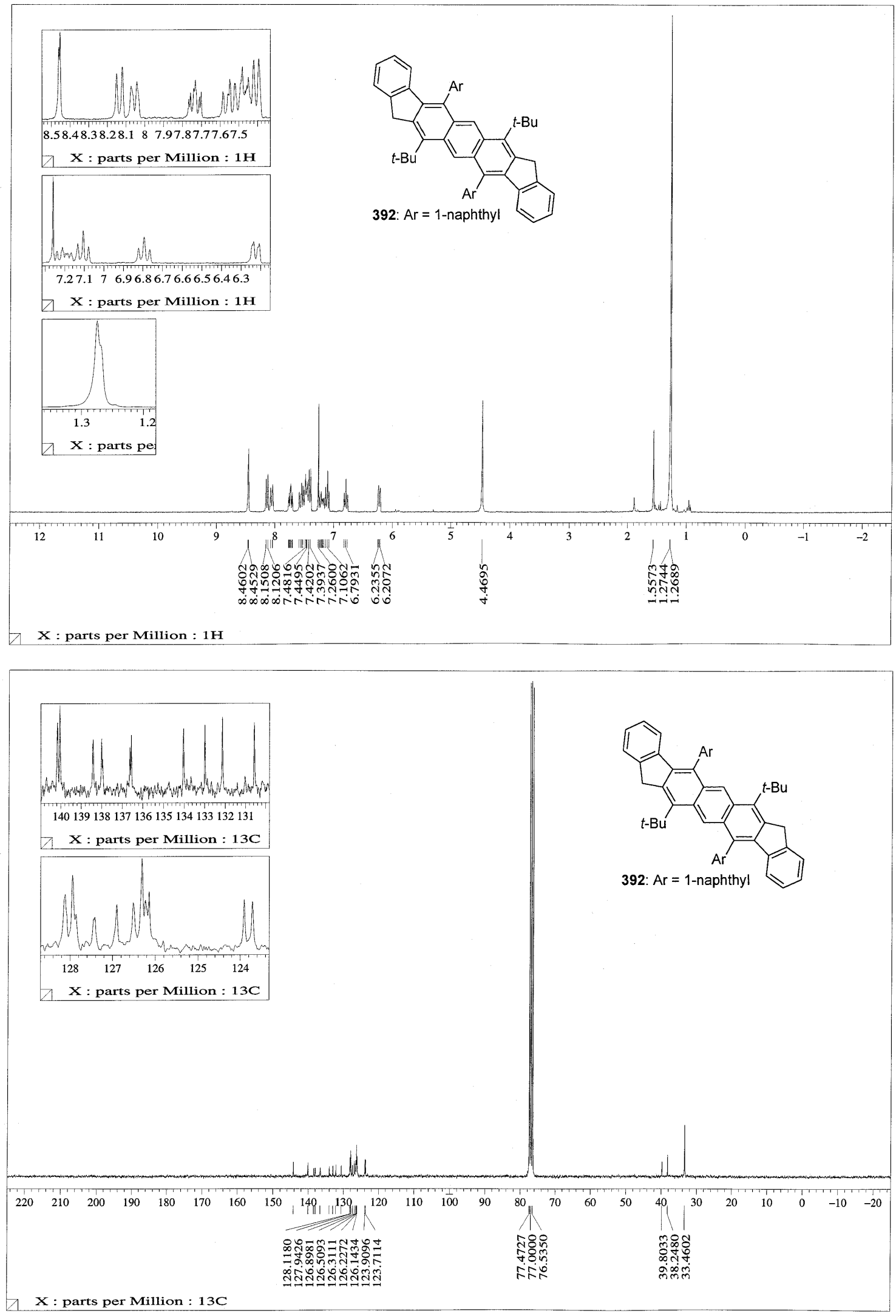

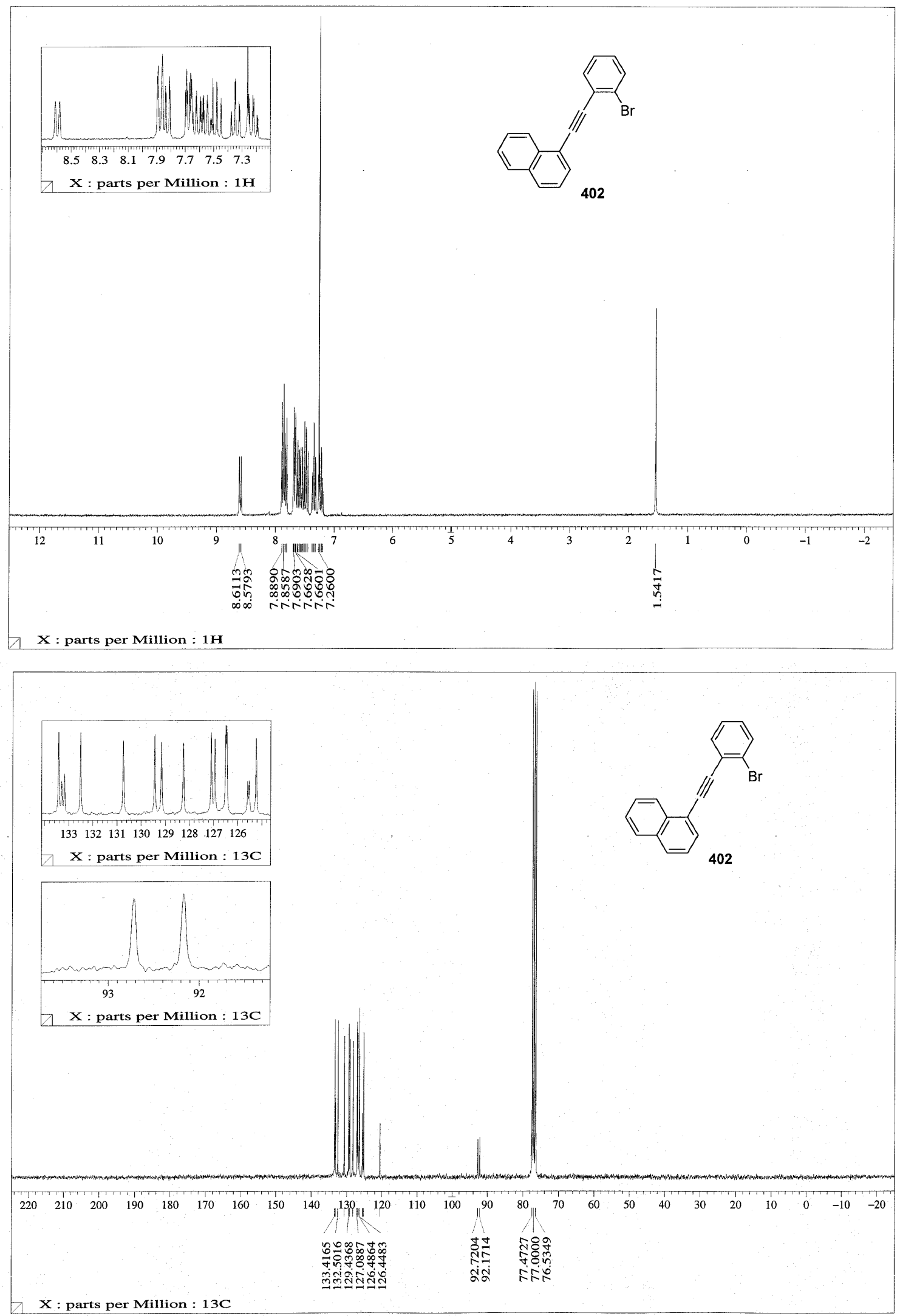

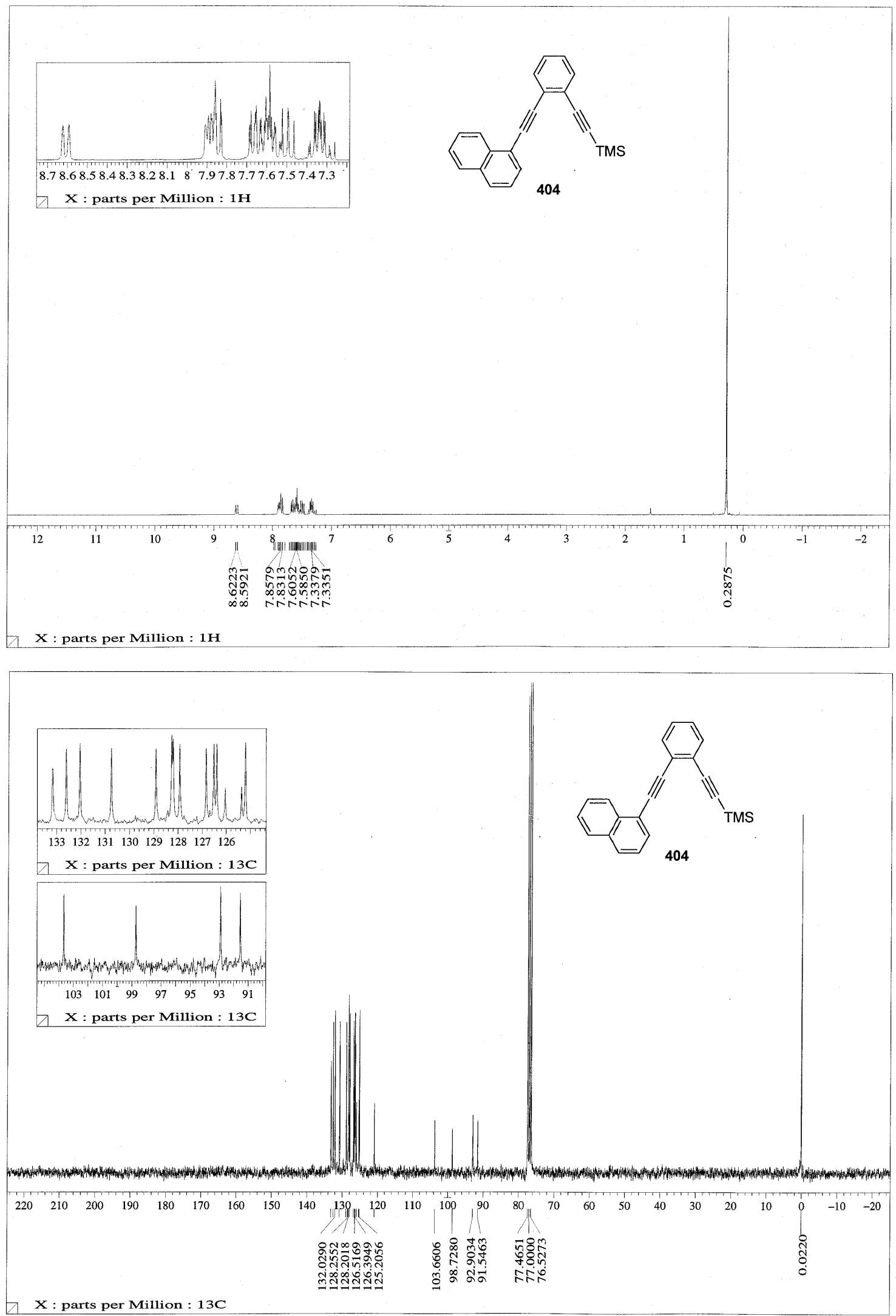

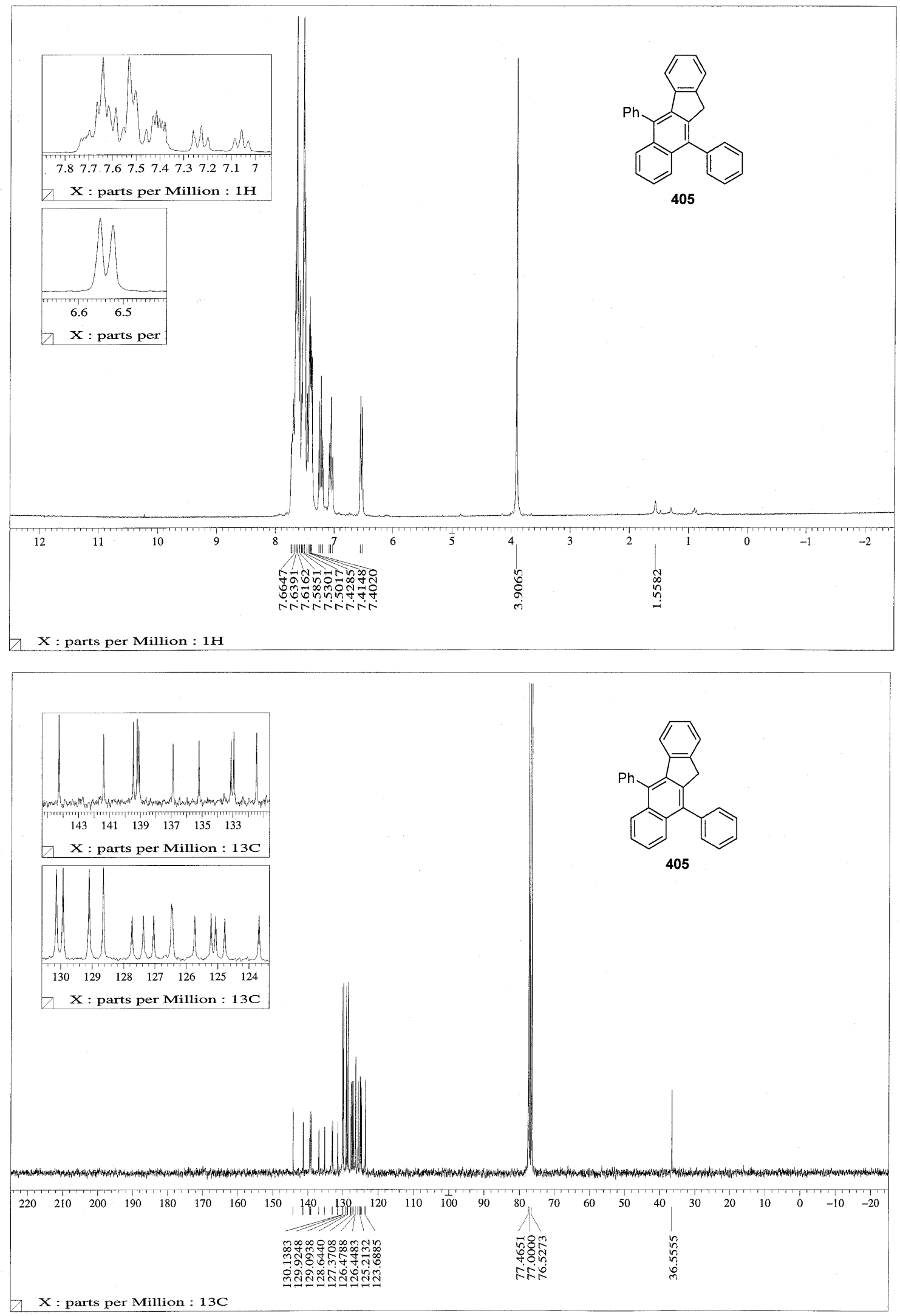

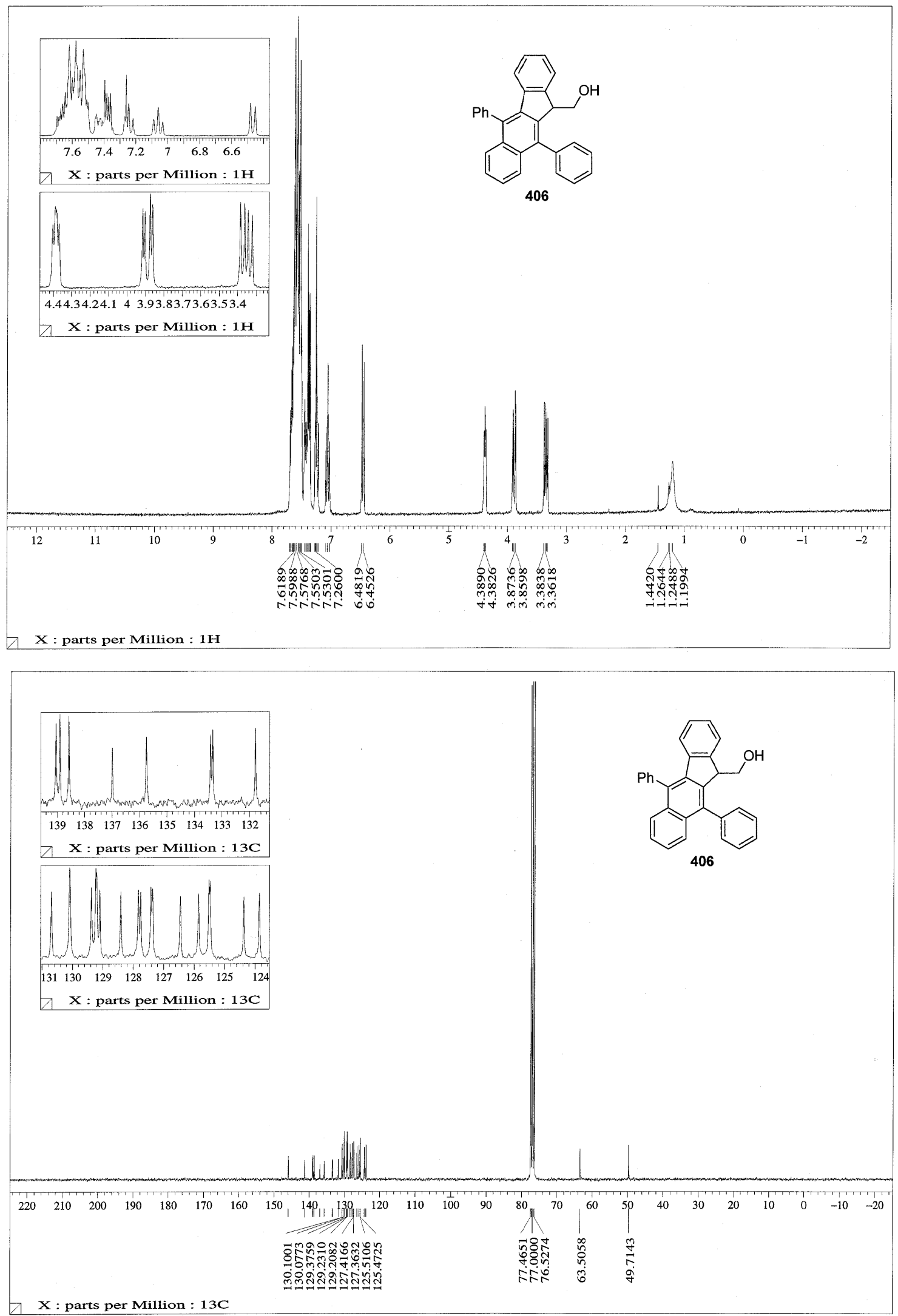

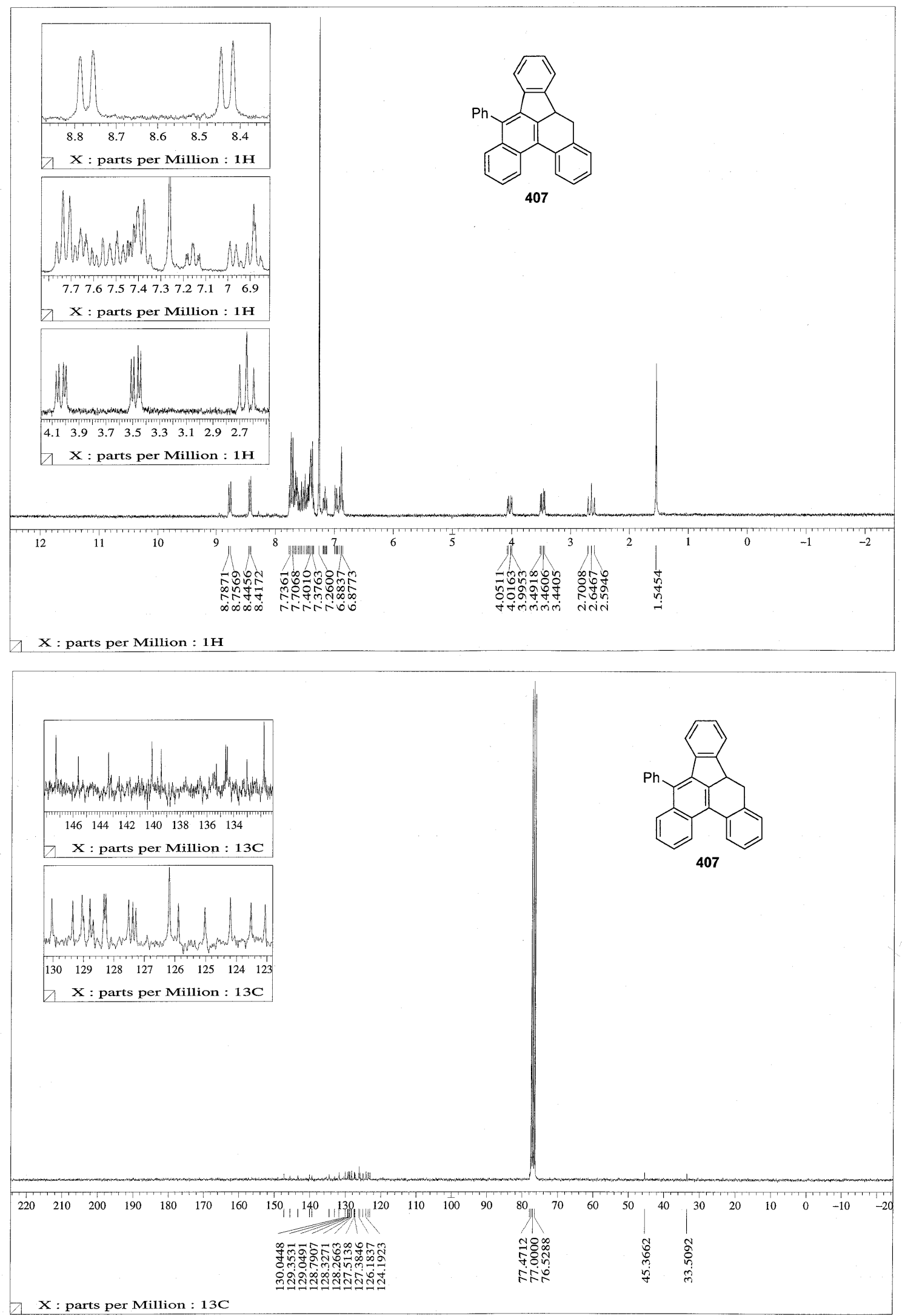


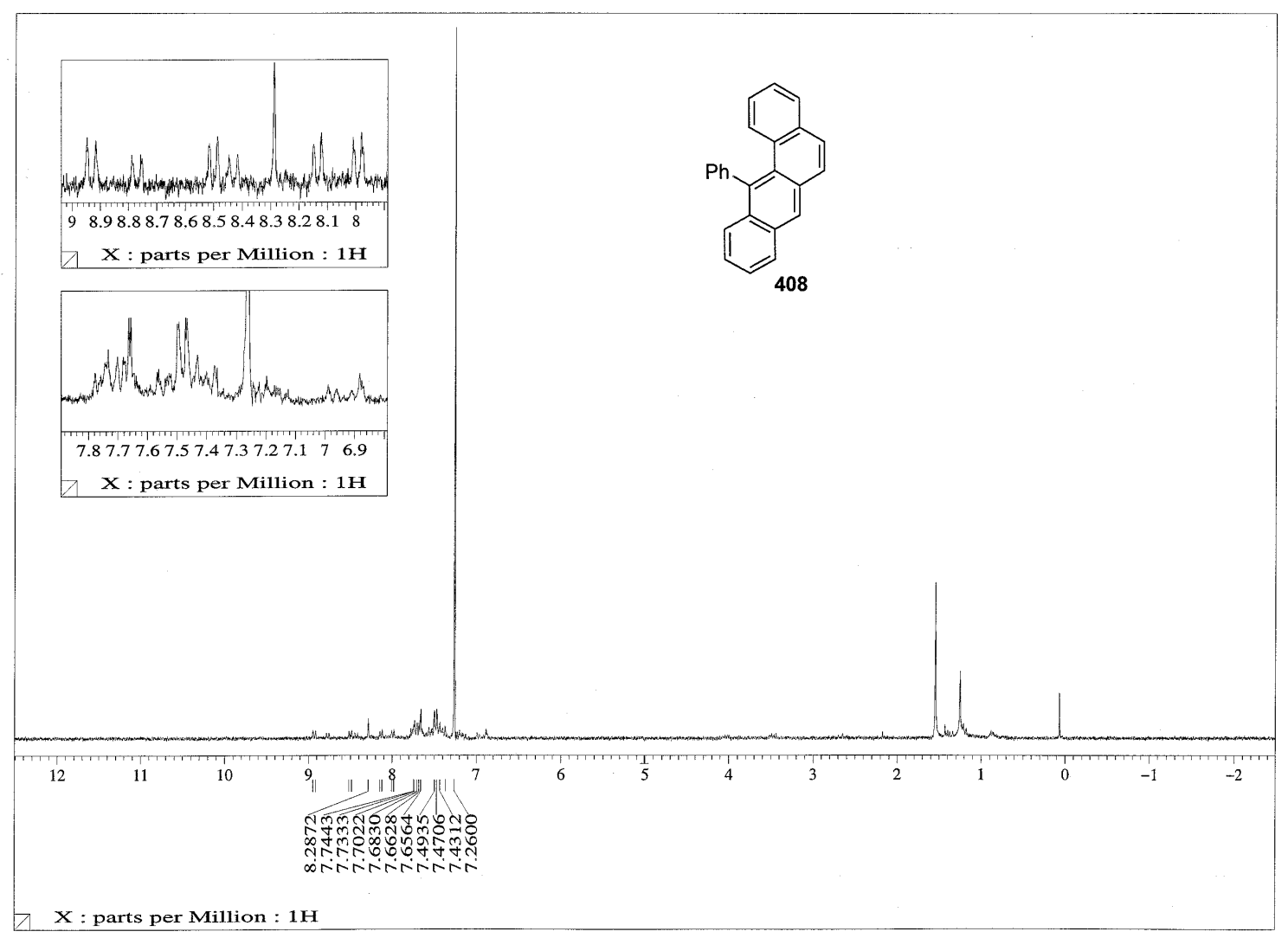



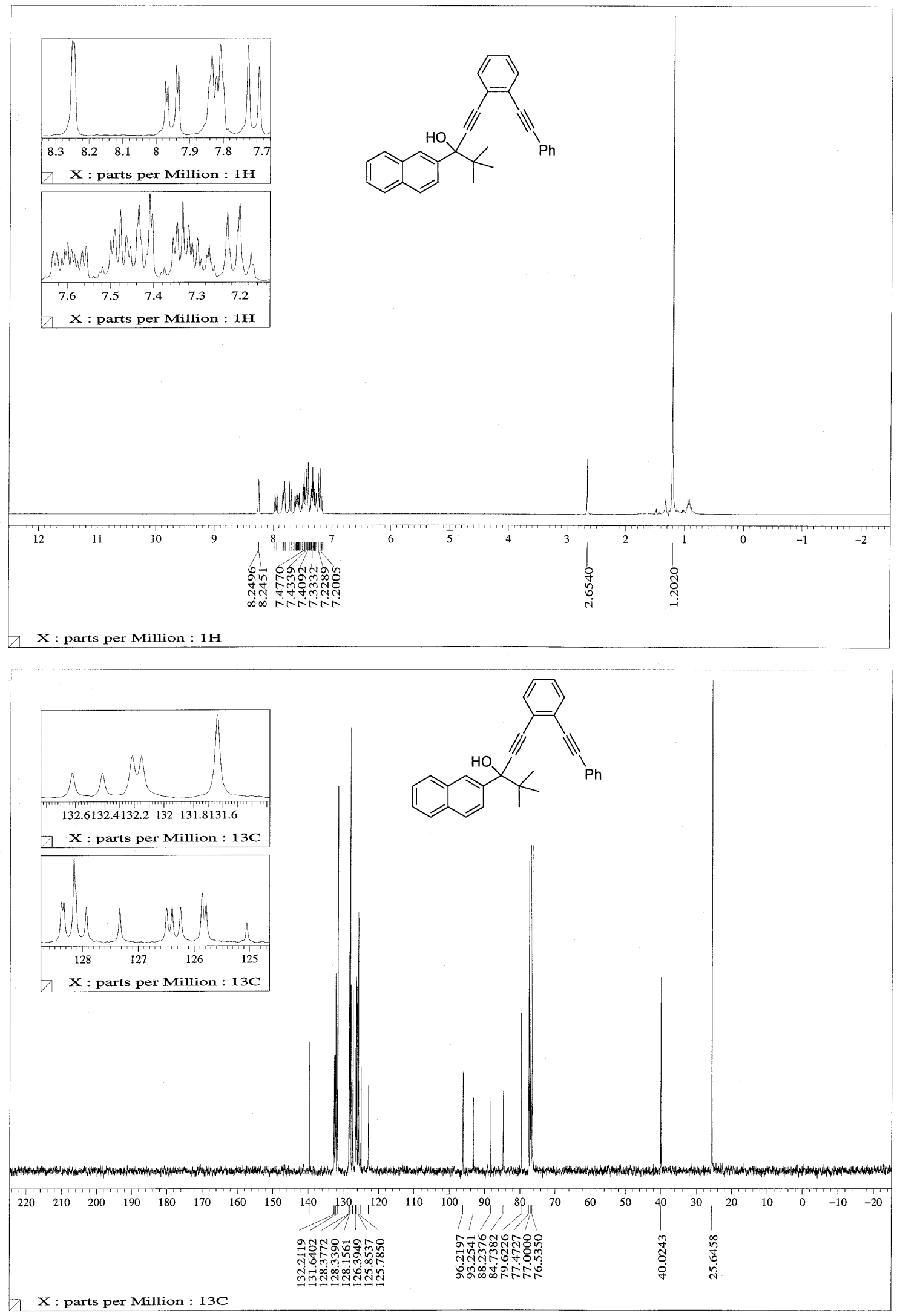

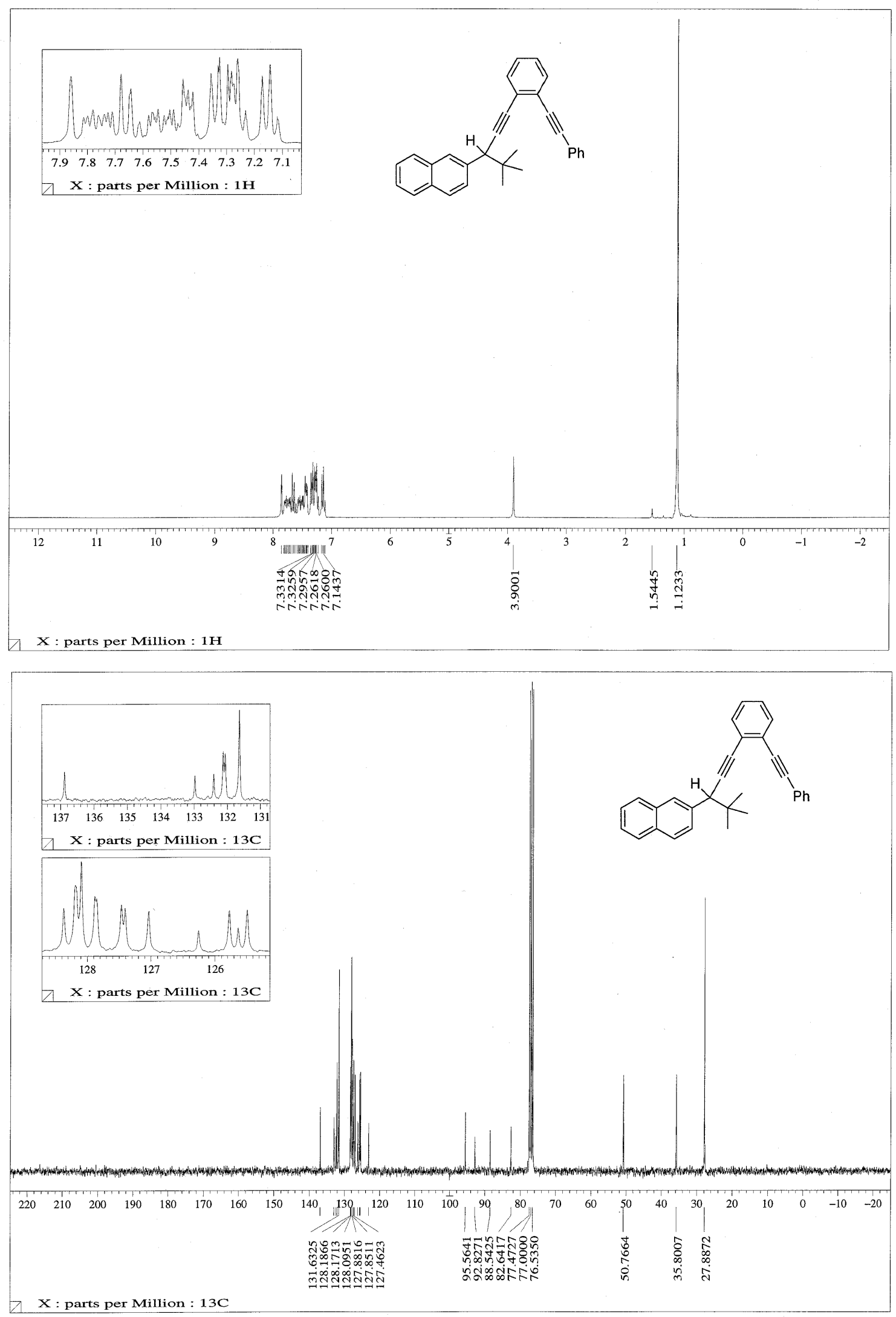


\section{PUBLICATIONS}

1. "Cascade Radical Cyclizations of Benzannulated Enyne-Allenes. Unusual Cleavage of a Benzene Ring Leading to Twisted 1,1'- Dialkyl-9,9'-bifluorenylidenes and Spiro[1Hcyclobut $[a]$ indene-1,9'-[9H]fluorenes]" Yang, Y.; Petersen, J. L.; Wang, K. K. J. Org. Chem. 2003, 68, 5832-5837.

2. "Polycyclic Aromatic Compounds via Radical Cyclizations of Benzannulated Enyne-Allenes Derived from Ireland-Claisen Rearrangement" Yang, Y.; Petersen, J. L.; Wang, K. K. J. Org. Chem. 2003, 68, 8545-8549.

3. "Unusual Cascade Reactions of Biradicals Generated from Benzoenyne-Allenes" Yang, Y.; Petersen, J. L.; Wang, K. K., presented at The Third Annual Meeting In Miniature Organized by the WVU Chapter of the ACS Students Affiliates, March 18, 2000.

4. "Cascade Radical Cyclizations of Benzannulated Enyne-Allenes. Unusual Cleavage of a Benzene Ring Leading to Twisted 1,1'- Dialkyl-9,9'-bifluorenylidenes and Spiro[ $1 \mathrm{H}$ cyclobut $[a]$ indene-1,9'-[9H]fluorenes]" Yang, Y.; Petersen, J. L.; Wang, K. K., presented at The $225^{\text {th }}$ American Chemical Society National Meeting, New Orleans, LA, March 23-27, 2003.

5. "Unusual Cascade Radical Cyclizations of Molecules Having Two Units of Benzannulated Enyne-Allene Leading to Novel Polycyclic Compounds" Yang, Y.; Petersen, J. L.; Wang, K. K., presented at Meeting-In-Miniature Hosted by the WVU Chapter of the ACS Students Affiliates, April 5, 2003. 